\title{
Particle-wall shear stress measurements within the standpipe of a circulating fluidized bed
}

Angela Marie Sarra

West Virginia University

Follow this and additional works at: https://researchrepository.wvu.edu/etd

\section{Recommended Citation}

Sarra, Angela Marie, "Particle-wall shear stress measurements within the standpipe of a circulating fluidized bed" (2001). Graduate Theses, Dissertations, and Problem Reports. 1165.

https://researchrepository.wvu.edu/etd/1165

This Thesis is protected by copyright and/or related rights. It has been brought to you by the The Research Repository @ WVU with permission from the rights-holder(s). You are free to use this Thesis in any way that is permitted by the copyright and related rights legislation that applies to your use. For other uses you must obtain permission from the rights-holder(s) directly, unless additional rights are indicated by a Creative Commons license in the record and/ or on the work itself. This Thesis has been accepted for inclusion in WVU Graduate Theses, Dissertations, and Problem Reports collection by an authorized administrator of The Research Repository @ WVU. For more information, please contact researchrepository@mail.wvu.edu. 
Particle-Wall Shear Stress Measurements within the Standpipe of a Circulating Fluidized Bed

\author{
Angela M. Sarra \\ Thesis submitted to the \\ College of Engineering and Mineral Resources \\ at West Virginia University \\ in partial fulfillment of the requirements \\ for the degree of
}

\author{
Master of Science \\ in \\ Chemical Engineering \\ Aubrey L. Miller. Ph.D., Advisor \\ Eung H. Cho, Ph.D. \\ Lawrence J. Shadle, Ph.D. \\ Department of Chemical Engineering \\ Morgantown, West Virginia. \\ 2001
}

Keywords: Circulating Fluidized Beds, Standpipe, Particle Wall Shear Stress, Mixture Momentum Balance, Gas Solids Flow

Copyright 2001 Angela Sarra 


\title{
ABSTRACT \\ Particle-Wall Shear Stress Measurements within the Standpipe of a Circulating Fluidized Bed
}

\begin{abstract}
Angela M. Sarra
Although standpipes are essential to the operation of circulating fluidized bed systems (CFB), their hydrodynamics are poorly understood, and are often unpredictable in displaying effects such as hysteresis which could be due to forces such as particle-wall shear stress.

In this research the one-dimensional gas-solids mixture momentum balance is applied to the standpipe. Neglecting acceleration effects, the important forces are the gas and solids phase pressure drop, weight of the bed, and the particle-wall shear stress. Gas pressure drop is measured using differential pressure transducers. The weight of the bed is assumed constant. The wall shear stress is measured utilizing instruments developed by WVU and NETL in Morgantown. The solids phase pressure drop is inferred to be the residual portion of the momentum balance.

Estimations of these forces are included for both coke breeze and cork bed materials. An attempt to model shear stress and solids pressure has been made.
\end{abstract}




\section{ACKNOWLEDGEMENTS}

I would like to thank the administrators of the Swiger Fellowship from which I was financially supported. I would also like to thank my advisor, Aubrey Miller, for his support and encouragement. I would like to thank Larry Shadle for working very closely with me and giving me the opportunity to work with the group of scientists at the Department of Energy National Energy Technology Laboratory in Morgantown WV. It was an exceptional opportunity to work with this dynamic team and also to work with such large-scale equipment. I would like to thank Larry Lawson and Chris Ludlow of the Department of Energy for listening and offering many helpful suggestions. I would also like to thank Randy Carter for the drawing and expertise in designing the wall probe, and Jim Devault for taking time to show me how to use equipment properly. 


\section{TABLE OF CONTENTS}

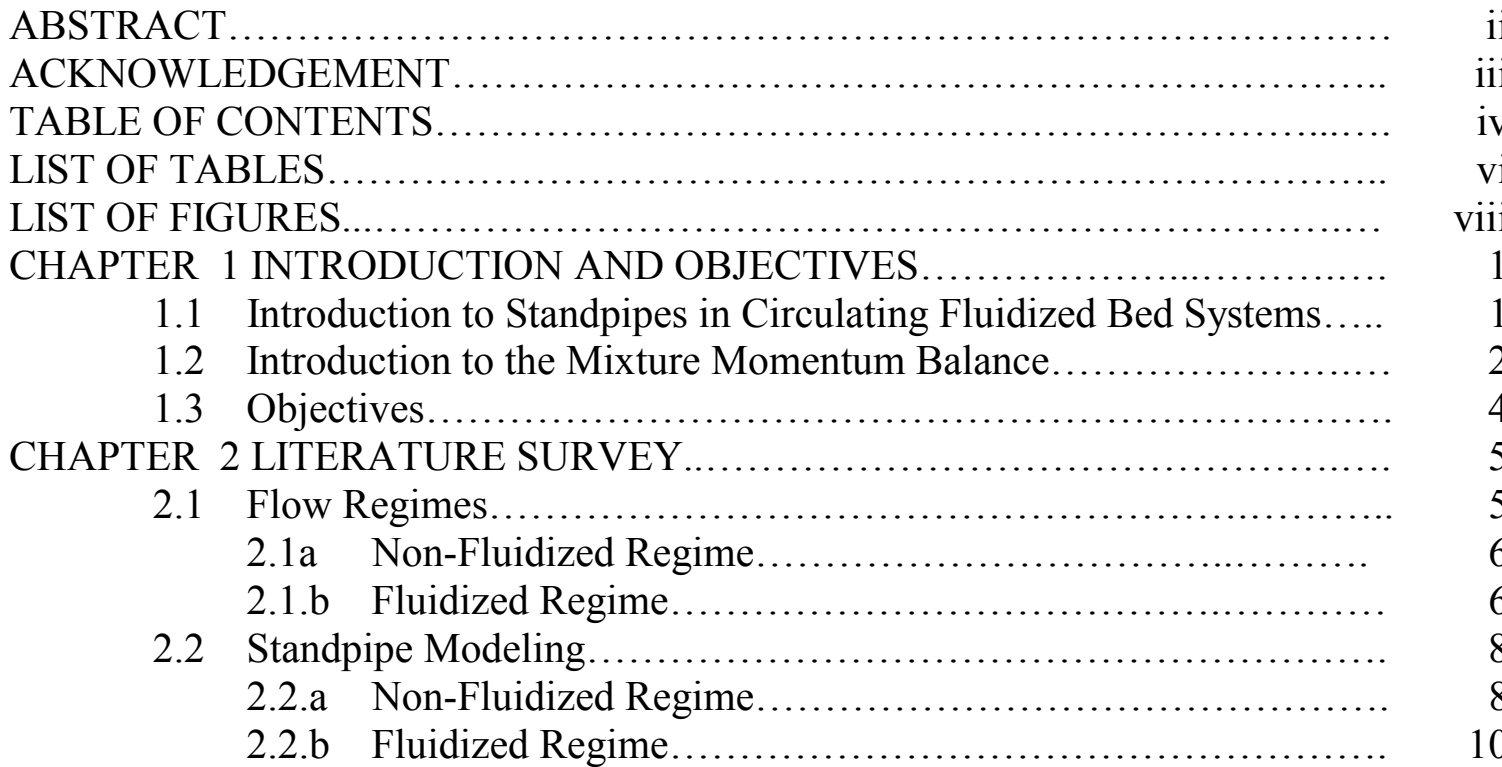

2.3 Standpipe Experimental Studies of Solids Pressure and Solids

Friction...................................................... 11

2.3.a Solids-Wall Shear Stress.................................... 11

2.3.b Solids Pressure.......................................... 16

CHAPTER 3 EXPERIMENTAL SET-UP...................................... 19

3.1 Circulating Fluid Bed......................................... 19

3.2 Bed Materials and Properties.................................. 21

3.3 Description of Mass Flow Device................................. 21

3.4 Shear Vane.................................................... 22

3.4a Shear Vane General Description........................... 22

3.4b Shear Vane Calibration and Error............................ 23

3.4c Parasitic Drag Characterization.............................. 24

$3.5 \quad$ Wall Probe ...................................................... 27

3.5a Wall Probe General Description............................. 27

3.5b Wall Probe Calibration........................................ 29

3.5c Wall Probe Purge......................................... 31

3.5d Wall Probe Repeatability..................................... 34

3.6 Capacitance Solids Volume Fraction Probe ......................... 37

3.6a Capacitance Solids Volume Fraction Probe General

Description........................................... 37

3.6b Capacitance Solids Volume Fraction Probe Calibration........ 38

3.6c Cork Particle Density Measurement......................... 41

3.7 Experimental Methods......................................... 42

3.7a Steady State versus Transient Data Sampling................. 42

3.7b Steady State versus Transient Aeration Ramps............... 42

3.8 Internal Angle of Friction and Angle of Wall Friction for the Bed Material.......................................................... 45

CHAPTER 4 RELATIVE COMPARISON OF FORCES IN A CFB AND THE JANSSEN COEFFICIENT. 
$4.1 \quad$ Mass Circulation................................................... 48

4.2 Momentum Balance Components During an Aeration Ramp......... 49

4.3 Differential Solids Pressure and Solids Wall Shear Stress Estimates.. 51

Chapter 5 DEPENDENCE OF SOLIDS WALL SHEAR STRESS AND SOLIDS PRESSURE ON OPERTAING CONDITIONS ................................... 60

$5.1 \quad$ Testing Theoretical Variables................................... 62

5.1a The Effects of Solids Circulation Rate on a Fluidized Regime................................................ 62

5.1b The Effect of Solids Circulation Rate and Standpipe Height on a Packed Regime..................................... 64

5.1c The Effect of Solids Circulation Rate and Gas Pressure Drop $\left(-\Delta \mathrm{P}_{\mathrm{g}} / \mathrm{L}\right)$ on a Packed Regime........................ 68

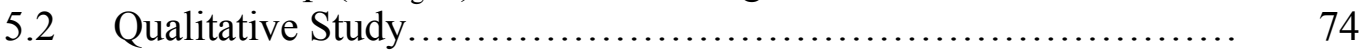

5.2a Filling and Draining Tests................................. 75

5.2b Stationary Bed Aeration Ramps, Coke, in the Standpipe...... 77

5.2c Bubbling Bed Studies, Nylon Beads, in the 10" Test Bed.... 82

5.2d Bubbling Bed Studies, Cork, in the 10" Test Bed........... 85

5.2e Circulating Bed Aeration Ramp Tests..................... 86

5.2f Circulating Bed Aeration Ramp Tests - Low Flows.......... $\quad 90$

5.3 CFB Operational Variables..................................... 92

5.3a The Effect of Solids Circulation Rate and Riser Pressure Drop............................................... 92

5.3b Four Factor Test: Standpipe Height, Riser Flow, Loopseal Flow, and Solids Circulation Rate........................ 96

5.3c The effect of Standpipe Aeration Rate, Riser Gas Velocity, and Fines Concentration................................... 102

5.3d The Effect of Location of Standpipe Move Air, Aeration at 20.8 feet, and Direction of Ramp.......................... 110

CHAPTER 6 CONCLUSIONS.............................................. 116

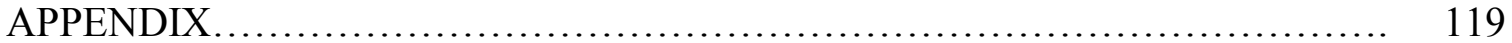

A.1 Derivation of Mixture Momentum Balance using Shell Balance Technique.

A.1.a Gas Momentum Balance.................................... 119

A.1.b Solids Momentum Balance............................... 121

A.1.c Mixture Momentum Balance........................... 122

A.2 Derivation of Equations For Estimating Shear Stress and Solids Pressure.............................................................. 123

A.2a Assuming Constant $\Delta \mathrm{P}_{\mathrm{g}} / \mathrm{L}$ Along the Standpipe............. 123

A.2b Integrating the Mixture Momentum Balance from $\mathrm{z}=\mathrm{z}_{1}$ to

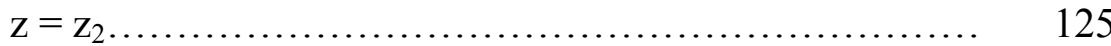

A.3 Bulk Solids Mechanics...................................... 129

NOMENCLATURE ...................................................... 133

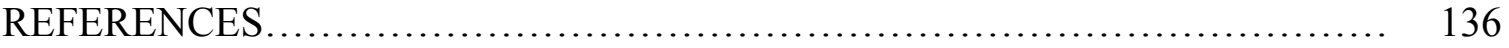




\section{LIST OF TABLES}

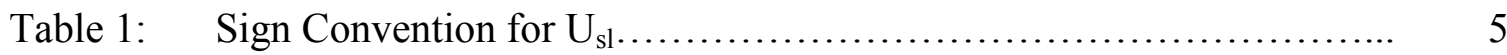

Table 2: $\quad$ Modeling Solids-Wall Shear Stress for Non-Fluidized Regime......... $\quad 10$

Table 3: $\quad$ Modeling Solids-Wall Shear Stress for Fluidized Regimes............. 11

Table 4: $\quad$ Riser Conditions and Shear Stress (Van Swaaij, 1970)................. 13

Table 5: $\quad$ Commercial Data on Solids-Wall Friction (Matsen, 1976)............. 14

Table 6: Independent Variable Levels for the Parasitic Drag Test............... 24

Table 7: Description and Values of Constants in Equation Describing Deflection of a Cantilever Beam.................................... 28

Table 8: $\quad$ Test Matrix to Understand Purge Air Effects, Test Bed, $1000 \mu \mathrm{m}$ Cork 32

Table 9: $\quad$ ANOVA of Purge Air Test for Shear Stress, Test Bed, $1000 \mu \mathrm{m}$ Cork. 33

Table 10: Test Sequence of Repeatability Test................................ 35

Table 11: Solids Volume Fraction Probe Calibration Constants................... 39

Table 12: Solids Volume Fraction Probe Calibration Results....................... 40

Table 13: Cork Particle Density Measurements.............................. 42

Table 14: Comparison of Relative Magnitude of Forces ( $\%$ of Total Force) for

Cork and Coke Breeze................................................ 51

Table 15: Estimated values of the Janssen Coefficient............................ 59

Table 16: Operational Variables Tested.......................................... 61

Table 17: Solids Circulation and Standpipe Height Test Independent Variables... 65

Table 18: Solids Circulation and Standpipe Height Results, Cork................ 66

Table 19: ANOVA Results for the Shear Stress Component of the Solids Circulation and Standpipe Height Test, Cork....................... 67

Table 20: ANOVA Results for the Solids Pressure Component of the Solids Circulation and Standpipe Height Test, Cork...................... 67

Table 21: Solids Circulation and Gas Pressure Drop $\left(-\Delta \mathrm{P}_{\mathrm{g}} / \mathrm{L}\right)$ Test Independent

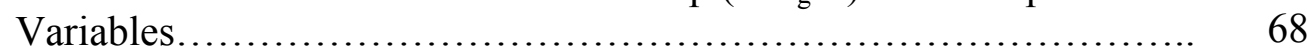

Table 22: Solids Circulation and Gas Pressure Drop $\left(-\Delta \mathrm{P}_{\mathrm{g}} / \mathrm{L}\right)$ Test Results, Cork. 68

Table 23: ANOVA Results for the Shear Stress Component of the Solids Circulation and Gas Pressure Drop $\left(-\Delta \mathrm{P}_{\mathrm{g}} / \mathrm{L}\right)$ Test, Cork................

Table 24: ANOVA Results for Solids Pressure Drop $\left(-\Delta \mathrm{P}_{s} / \mathrm{L}\right)$ of the Solids Circulation and Gas Pressure Drop $\left(-\Delta \mathrm{P}_{\mathrm{g}} / \mathrm{L}\right)$ Test, Cork .............. 70

Table 25: Solids Circulation and Gas Pressure Drop $\left(-\Delta \mathrm{P}_{\mathrm{g}} / \mathrm{L}\right)$ Test, Higher Circulation Rates, Independent Variables............................... 71

Table 26: Solids Circulation and Gas Pressure Drop $\left(-\Delta \mathrm{P}_{\mathrm{g}} / \mathrm{L}\right)$ Test, Higher Circulation Rates, Results, Cork.

Table 27: ANOVA Results for the Shear Stress Component of the Solids Circulation and Gas Pressure Drop $\left(-\Delta \mathrm{P}_{\mathrm{g}} / \mathrm{L}\right)$ Test, Higher Circulation Rates, Cork..........................................................

Table 28: ANOVA Results for the Solids Pressure Component of the Solids Circulation and Gas Pressure Drop $\left(-\Delta \mathrm{P}_{\mathrm{g}} / \mathrm{L}\right)$ Test, Higher Circulation

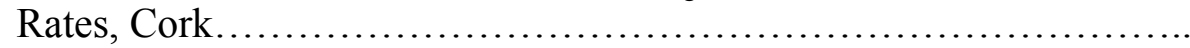

Table 29: $\quad$ ANOVA Results for the Solids Volume Fraction of the Solids Circulation and Gas Pressure Drop $\left(-\Delta \mathrm{P}_{\mathrm{g}} / \mathrm{L}\right)$, Higher Circulation rates, Cork 
Table 30: Filling and Draining Test Variables, $230 \mu \mathrm{m}$ Coke..................... 75

Table 31: Stationary Bed Aeration Ramp Variables, Riser Flow, 10,000 scfh, $230 \mu \mathrm{m}$ Coke.

Table 32: Stationary bed Aeration Ramp Variables, Riser Flow 50,000 scfh, 230 $\mu \mathrm{m}$ Coke

Table 33: Circulating Bed Aeration Ramp Variables, $230 \mu \mathrm{m}$ Coke................

Table 34: Circulating Bed Aeration Ramp Variables, Aeration at the Bottom, $230 \mu \mathrm{m}$ Coke.

Table 35: Riser Pressure Drop and Solids Circulation Rate Test Independent Variables, $230 \mu \mathrm{m}$ Coke.

Table 36: Riser Pressure Drop and Solids Circulation Rate Test Results, $230 \mu \mathrm{m}$ Coke.

Table 37: ANOVA of Riser Pressure Drop and Solids Circulation Test for Shear Stress $\left(-2 \tau_{\mathrm{sw}} / \mathrm{R}\right), 230 \mu \mathrm{m}$ Coke.................................. 94

Table 38: ANOVA of Riser Pressure Drop and Solids Circulation Test for Gas Pressure Drop $\left(-\Delta \mathrm{P}_{\mathrm{g}} / \mathrm{L}\right), 230 \mu \mathrm{m}$ Coke.

Table 39: ANOVA of Riser Pressure drop and Solids Circulation Test for Solids Pressure Drop $\left(-\Delta \mathrm{P}_{\mathrm{s}} / \mathrm{L}\right), 230 \mu \mathrm{m}$ Coke............................ 96

Table 40: Four Factor Test Independent Variables............................. 97

Table 41: Four Factor Test Results, $230 \mu \mathrm{m}$ Coke................................ 98

Table 42: $\quad$ ANOVA of Four Factor Test for Shear Stress $\left(-2 \tau_{\mathrm{sw}} / \mathrm{R}\right), 230 \mu \mathrm{m}$ Coke. $\quad 99$

Table 43: ANOVA of Four Factor Test for Gas Pressure Drop $\left(-\Delta \mathrm{P}_{\mathrm{g}} / \mathrm{L}\right)$ across the shear vane, $230 \mu \mathrm{m}$ Coke.

Table 44: $\quad$ ANOVA of four Factor Test for Solids Pressure Drop $\left(-\Delta \mathrm{P}_{\mathrm{s}} / \mathrm{L}\right), 230$ $\mu \mathrm{m}$ Coke.

Table 45: Standpipe Aeration Rate, Riser Gas Velocity and Fines Level Test Independent Variables

Table 46: Standpipe Aeration Rate, Riser Gas Velocity and Fines Level Test Independent Variable Results, Coke.

Table 47: $\quad$ Standpipe Aeration Rate, Riser Gas Velocity, and Fines Level Test Dependent Variable Results, Coke.

Table 48: Standpipe Aeration Rate, Riser Gas Velocity and Fines Level Test Dependent Variable Results-continued, Coke.

Table 49: ANOVA of Fines Test for Shear Stress Component, Coke...............

Table 51: ANOVA of Fines Test for Dependent Variables- Continued, Coke.

Table 52: Standpipe Aeration Location, Aeration at 20.8', and Ramp Direction Test Matrix

Table 53: Standpipe Aeration Location, Aeration at 20.8', and Ramp Direction Dependent Variable Results, $230 \mu \mathrm{m}$ Coke.

Table 54: ANOVA Results of the Shear Stress Component of the Hysteresis Test, $230 \mu \mathrm{m}$ Coke.

Table 55: ANOVA of Hysteresis Test for Gas Pressure Drop $\left(-\Delta \mathrm{P}_{\mathrm{g}} / \mathrm{L}\right)$, Solids Pressure Drop $\left(-\Delta \mathrm{P}_{\mathrm{s}} / \mathrm{L}\right)$, Solids Circulation And Standpipe Height, 230 $\mu \mathrm{m}$ Coke 


\section{LIST OF FIGURES}

Figure 1: Standpipe Force Balance

Figure 2: Moveable Wall Device for Solids-Wall Shear Stress (Van Swaaij, 1970).......

Figure 3: Shear Stress versus Solids Flux in a Pneumatic Riser (Van Swaaij, 1970).

Figure 4:

Figure 5:

Figure 6:

Figure 7:

Pressure Drop and Mean Densities (Van Swaaij, 1970)....

Solids-Wall Friction Versus Density of the Bed (Matsen, 1976)...... 14

Tube-Pulling Apparatus (Zenz, 1960)............................. 16

Figure 8:

Tube-Pulling Experimental Results (Zenz, 1960)................... 16

Figure 9:

Figure 10:

Solids Pressure Probes (Polashenski, 1999).....

Solids Pressure versus Local Solid fraction (Polashenski, 1999)...... 18

Figure 11:

NETL Circulating Fluid Bed...................................... 20

Figure 12:

Spiral, Mass Circulation Measurement............................ 22

Figure 13:

Shear Vane Schematic........................................... 23

Figure 14:

Shear Vane Calibration............................................. 23

Figure 15:

Parasitic Drag Steady Steady State, $230 \mu \mathrm{m}$ Coke. ....

Total Force Measured for Each Vane Length and Parasitic Drag, 230 $\mu \mathrm{m}$ Coke.

Figure 16:

Ratio of Shear Force/Total Force (Parasitic Drag study), $230 \mu \mathrm{m}$

Coke.

Figure 17:

Wall Stress Probe Schematic.

Figure 18:

Factory Supplied Calibration of Displacement Probes, Channel 1.....

Figure 19:

Factory Supplied Calibration of Displacement Probes, Channel 2.....

Figure 20:

Wall Probe Calibration in the Axial Direction. ...

Figure 21:

Estimated and Measured Movement of the Tube

Figure 22:

Importance of Probe Level on Calibration.

Figure 23:

Effects of Purge on Wall Probe Measurements, $1000 \mu \mathrm{m}$ Cork........

Figure 24:

The Effects of Ramp Direction on Wall Shear, $1000 \mu \mathrm{m}$ Cork..........

Figure 25:

Hysteresis Effect of Wall Probe

Figure 26:

Wall Probe Repeatability Study......

Figure 27:

Wall Probe Measurement Error for Coke Breeze Range...............

Figure 28:

Wall Probe Measurement Error for Cork Range.

Wall Probe Measurement Error for Coke Breeze Range No Nylon... 36

Figure 29:

Wall Probe Measurement Error for Cork Range No Nylon.............

Figure 30:

Solids Volume Fraction Probe (Louge, 1992).

36

38

Figure 32:

Figure 33:

Calibration Results of the Solids Volume Fraction Probe...

41

Transient Aeration Ramp....

43

Steady State Aeration Ramp

43

Figure 34:

Comparison of Steady State and Transient Ramps for Solids

Circulation, $230 \mu \mathrm{m}$ Coke.

Figure 36: Comparison of Steady State and Transient Ramps for Gas Phase

Pressure Drop, $230 \mu \mathrm{m}$ Coke.

Figure 37: Comparison of Steady State and Transient Ramps for Solids-Wall Shear Stress, $230 \mu \mathrm{m}$ Coke. 
Figure 38: Internal angle of Friction Measurement Apparatus.................. 45

Figure 39: Measurement of Angle of Wall Friction............................ 46

Figure 40: $\quad$ Solids Circulation versus Aeration, $230 \mu \mathrm{m}$ Coke..................... 48

Figure 41: Momentum Balance Components versus Solids Circulation, $230 \mu \mathrm{m}$ Coke....................................................... 49

Figure 42: Momentum Balance Components versus Aeration, Steady States, Cork Bed material............................................ $\quad 50$

Figure 43: $\quad$ Estimated Values of $\Delta \mathrm{P}_{\mathrm{s}} / \mathrm{L}$ versus Mass Circulation, $230 \mu \mathrm{m}$ Coke... $\quad 54$

Figure 44: Measured and Estimated Values of $-2 \tau_{\mathrm{sw}} / \mathrm{R}$ versus Mass Circulation, $230 \mu \mathrm{m}$ Coke.................................................. 54

Figure 45: $\quad$ Measured and Estimated Values of $-4 \tau_{\mathrm{sw}} / \mathrm{D}$ versus Solids Circulation, Coke Breeze..................................... 55

Figure 46: Jenike Shear Cell Measurements of Coke Breeze.................. 56

Figure 47: The Variation of the Product of the Coefficient of Friction and the Janssen Coefficient with Normal Stress............................ 56

Figure 48: $\quad$ Estimated Values of $-\Delta \mathrm{P}_{\mathrm{s}} / \mathrm{L}$ versus Solids Volumetric Flux........... 57

Figure 49: $\quad$ Measured and Estimated Values of $-2 \tau_{\mathrm{sw}} / \mathrm{R}$ versus Solids Volumetric Flux, Cork......................................... 58

Figure 50: Measured and Estimated Values of $-\Delta \mathrm{P}_{\mathrm{s}} / \mathrm{L}$ versus Solids Volumetric Flux, Cork................................................. 58

Figure 51: Shear Stress Measured by the Shear Vane and Wall Probe for a Fluidized Regime, Cork......................................

Figure 52: Shear Stress Measured by the Wall Probe for a Fluidized Regime, Cork.......................................................... 63

Figure 53: Momentum Balance Components versus Solids Circulation for a Fluidized Regime, Cork......................................... 64

Figure 54: Shear Stress Component Zero, Cork........................... 64

Figure 55: Effect of Solids Circulation and Standpipe Height on the Shear Stress Component for a Packed Regime, Cork.................... 66

Figure 56: The Effect of Solids Circulation and Standpipe Height on the Solids Pressure Component for a Packed Regime, Cork.................. 66

Figure 57: The Effect of Solids Circulation and Gas Pressure Drop $\left(-\Delta \mathrm{P}_{\mathrm{g}} / \mathrm{L}\right)$ on the Shear Stress Component for a Packed Regime, Cork.............

Figure 58: The Effect of Solids Circulation and Gas Pressure Drop $\left(-\Delta \mathrm{P}_{\mathrm{g}} / \mathrm{L}\right)$ on the Solids Pressure Component for a Packed Regime, Cork...........

Figure 59: The Effect of Solids Circulation and Gas Pressure Drop $\left(-\Delta \mathrm{P}_{\mathrm{g}} / \mathrm{L}\right)$ (at Higher Circulation Rates) on the Shear Stress Component...........

Figure 60: The Effect of Solids Circulation and Gas Pressure Drop $\left(-\Delta \mathrm{P}_{\mathrm{g}} / \mathrm{L}\right)$ (at Higher Circulation Rates) on the Solids Pressure Component........

Figure 61: The Effect of Solids Circulation and Gas Pressure Drop $\left(-\Delta \mathrm{P}_{\mathrm{g}} / \mathrm{L}\right)$ (at Higher Circulation Rates) on the Solids Volume Fraction.........

Figure 62: Shear Stress Versus Bed Height, Filling and Draining Tests, $230 \mu \mathrm{m}$ Coke.....................................................

Figure 63: Gas Phase Pressure Drop versus Bed Height, Draining and Filling Tests, $230 \mu \mathrm{m}$ Coke. 
Figure 64: Shear Stress versus Aeration for a Stationary Bed, $230 \mu \mathrm{m}$ Coke......

Figure 65: Momentum Balance Components for a Stationary Bed (Ramp Up), $230 \mu \mathrm{m}$ Coke.

Figure 66: Momentum Balance Components for a Stationary Bed (Ramp Down), $230 \mu \mathrm{m}$ Coke

Figure 67: Momentum Balance Components for a Stationary Bed Ramp, High Riser Flow, $230 \mu \mathrm{m}$ Coke

Figure 68: Shear Stress versus Aeration Rate, Stationary Bed, High Riser Flow, $230 \mu \mathrm{m}$ Coke.

Figure 69:

Bubbling Bed Aeration Ramp for Nylon Bead Bed Material.

Figure 70:

Bubbling Bed Aeration Ramp for Nylon Bead Bed Material,

Decreasing Aeration.

Figure 71: Bubbling Bed Aeration Ramp for Nylon Beads Bed Material, After Compaction.

Figure 72: Bubbling Bed Aeration Ramp for Nylon Bead Bed Material, After Compaction, Decreasing Aeration.

Figure 73: Comparison of the Wall Probe Measurement for the Nylon Bead Bubbling Bed Study....

Figure 74:

Comparison of the Shear Vane Measurements for the Nylon Bead Bubbling Bed Study....

Figure 75: Bubbling Bed Aeration Ramp for Cork Bed Material

Figure 76: Bubbling Bed Aeration Ramp for Cork Bed Material, Decreasing Aeration

Figure 77:

Bubbling Bed Ramp 2, Cork Bed Material, Increasing Aeration..... Bubbling Bed Ramp 2, Cork Bed Material, Decreasing Aeration....

Figure 79: Momentum Balance Components for a Circulating Bed Aeration Ramp, $230 \mu \mathrm{m}$ Coke.

Figure 80: Mass Circulation and Standpipe Bed Height versus Aeration rate, $230 \mu \mathrm{m}$ Coke.

Figure 81: Momentum Balance Components for a Circulating Bed Aeration Ramp, Aeration at the Bottom, $230 \mu \mathrm{m}$ Coke.

Figure 82: Shear Stress at Lower Aeration Ramps, $230 \mu \mathrm{m}$ Coke.

Figure 83:

Shear Stress Component and Gas Pressure Drop versus Aeration Rate for Low Flows, $230 \mu \mathrm{m}$ Coke.

Figure 84: Momentum Balance Components versus Aeration for Low Flows, $230 \mu \mathrm{m}$ Coke.

Figure 85: $\quad$ Shear Stress $\left(-2 \tau_{\mathrm{sw}} / \mathrm{R}\right)$ Results of $2 \mathrm{X} 2$ Factorial, Riser $\Delta \mathrm{P}$ and Solids Circulation, $230 \mu \mathrm{m}$ Coke.

Figure 86: Gas Pressure Drop $\left(-\Delta \mathrm{P}_{\mathrm{g}} / \mathrm{L}\right)$ Results of $2 \mathrm{X} 2$ Factorial, Riser $\Delta \mathrm{P}$ and Solids Circulation, $230 \mu \mathrm{m}$ Coke

Figure 87: Solids Pressure Drop $\left(-\Delta \mathrm{P}_{\mathrm{s}} / \mathrm{L}\right)$ Results of $2 \mathrm{X} 2$ Factorial, Riser $\Delta \mathrm{P}$ and Solids Circulation Rate, $230 \mu \mathrm{m}$ Coke.........................

Figure 88: Shear Stress $\left(-2 \tau_{\mathrm{sw}} / \mathrm{R}\right)$ Results of the Four Factor Test, $230 \mu \mathrm{m}$ Coke 98

Figure 89: Gas Pressure Drop $\left(-\Delta \mathrm{P}_{\mathrm{g}} / \mathrm{L}\right)$ Results of the Four Factor Test, $230 \mu \mathrm{m}$ Coke. 
Figure 90: $\quad$ Solids Pressure Drop $\left(-\Delta \mathrm{P}_{\mathrm{s}} / \mathrm{L}\right)$ of the Four Factor Test, $230 \mu \mathrm{m}$ Coke

Figure 91: Shear Stress Component Results of 3 Factor Factorial, Riser Gas Velocity, Standpipe Gas Velocity, and Fines Concentration, Coke....

Figure 92: $\quad$ Gas Pressure Drop $\left(-\Delta \mathrm{P}_{\mathrm{g}} / \mathrm{L}\right)$ Results of 3 Factor Factorial, Riser Gas Velocity, Standpipe Gas Velocity, and Fines Concentration, Coke....

Figure 93: $\quad$ Solids Pressure Drop $\left(-\Delta \mathrm{P}_{\mathrm{s}} / \mathrm{L}\right)$ Results of 3 Factor Factorial, Riser Gas Velocity, Standpipe Gas Velocity, and fines Concentration, Coke....

Figure 94: Bed Material Property Results of 3 Factor Factorial, Riser Gas Velocity, Standpipe Gas Velocity, and fines Concentration, Coke....

Figure 95: Results of Shear Stress component for the Hysteresis Test, $230 \mu \mathrm{m}$ Coke....

Figure 96: Results of Gas Pressure Drop Component for the Hysteresis Test, $230 \mu \mathrm{m}$ Coke

Figure 97: Results of Solids Pressure Drop Component for the Hysteresis Test,

Figure 98: $\quad$ Comparison of Hysteresis Test Replicates, $230 \mu \mathrm{m}$ Coke............. 114

Figure 99: Example of Five Minute Steady State for Run Two, $230 \mu \mathrm{m}$ Coke...

Figure 100: $\quad$ Example of Five Minute Steady State for Run Nine, $230 \mu \mathrm{m}$ Coke... 114

Figure 101: Standpipe Force Balance Shell Balance............................ 119

Figure 102: $\quad$ Derivation of Solids Pressure Equation Drawing 1................. 124

Figure 103: Derivation of Solids Pressure Equation Drawing 2................ 126

Figure 104: Differential Triangular Element............................... 129

Figure 105: Differential Element and Resulting Forces....................... 130

Figure 106: Mohr Stress Circle for Particulate Solids 1........................ 131

Figure 107: Mohr Stress Circle for Particulate Solids Maximum Ratio of $\tau$ to $P_{\text {s.. }} \quad 132$ 


\section{CHAPTER 1 INTRODUCTION AND OBJECTIVES}

\subsection{Introduction to Standpipes in Circulating Fluidized Bed Systems}

Circulating fluidized beds (CFB) are common in the chemical process industries. They are especially prevalent in the petroleum and electric power industry. Due to the development of highly active catalysts, circulating fluidized beds are replacing bubbling beds in the petroleum industries. Further, circulating fluidized bed combustors are becoming popular because of the potential of burning coal with low $\mathrm{SO}_{2}$ and $\mathrm{NO}_{\mathrm{x}}$ emissions. (Gidaspow, 1994)

The standpipe is an important component of the circulating fluidized bed. In a circulating fluid bed loop, the standpipe transports the recycled solids from a low pressure at the cyclone to a high pressure at the bottom of the standpipe. In industrial units, this pressure drop is necessary to prevent the "backflow" of gas in the riser up the standpipe, which could both severely spoil the efficiency of the cyclone and lead to the mixing of volatile chemicals. The standpipe is critical in ensuring the stable circulation

of mass in the CFB, which moderates temperature and stabilizes combustion at this low temperature. This allows the use of emission reducing sorbent since temperature is controlled in the right range. Shadle (1999) reported some examples of unstable solids circulation rates.

As indicated by Shadle (1999) variables such as inventory and aeration within the standpipe has a large impact on the mass circulation and the stability of mass circulation. Minimizing the aeration while maintaining a high stable mass circulation is desirable to minimize the amount of dilution of the feed. The mixture momentum balance on a section of standpipe gives insight into the forces impacting flow within it. Understanding how aeration affects these forces may be a key in obtaining high stable mass circulation with minimum aeration. Further, this understanding is important in predicting solids feed to the riser.

Due to the high interest in circulating fluidized bed technology in industry and due to the difficulties in scaling these systems, a large effort to model these systems is underway. 


\subsection{Introduction to the Mixture Momentum Balance}

To model the hydrodynamics for standpipes the important forces that contribute to both the gas and solids phase and momentum balances must be identified and understood. In this study the wall shear stress and solids pressure gradient are being studied. These are two important forces that have little experimental information available in the literature. Consider the section of standpipe in Figure 1.

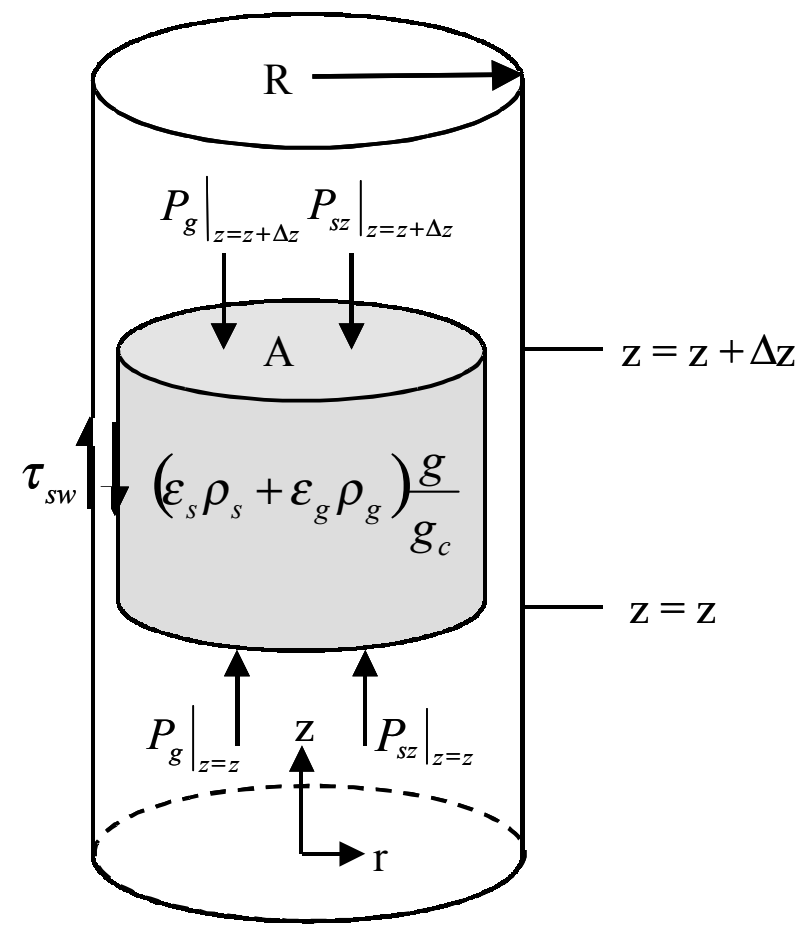

Figure 1: Standpipe Force Balance

The 3-dimensional momentum balance on the total mixture is as follows (Geankoplis, 1993) (Gidaspow, 1994):

$$
\frac{\partial}{\partial t} \iiint_{c v} \varepsilon_{s} \rho_{s} \vec{v}_{s} d V+\frac{\partial}{\partial t} \iiint_{c v} \varepsilon_{g} \rho_{g} \vec{v}_{g} d V+\iint_{c s} \varepsilon_{s} \rho_{s} \vec{v}_{s}\left(\vec{v}_{s} \cdot \vec{n}\right) d A+\iint_{c s} \varepsilon_{g} \rho_{g} \vec{v}_{g}\left(\vec{v}_{g} \cdot \vec{n}\right) d A=\sum F
$$

Writing the 1-dimensional momentum balance in the z-direction, using Cartesian coordinates on the total mixture gives the following:

$$
\frac{\partial}{\partial t} \iiint_{c v} \varepsilon_{s} \rho_{s} v_{s z} d V+\frac{\partial}{\partial t} \iiint_{c v} \varepsilon_{g} \rho_{g} v_{g z} d V+\iint_{c s} \varepsilon_{s} \rho_{s} v_{s z} \vec{v}_{s} \cdot \vec{n} d A+\iint_{c s} \varepsilon_{g} \rho_{g} v_{g z} \vec{v}_{g} \cdot \vec{n} d A=\sum F_{z}
$$

The first two terms are the accumulation of momentum for the gas and solids phase, and because the system is assumed to be in steady state, they are assumed to be 
zero. The remaining two terms stand for the net outflow of momentum. If we assume plug flow and that bulk density is constant across the cross section, the net outflow of momentum can be expressed by Equation (3).

$$
\iint_{c s} \varepsilon_{s} \rho_{s} v_{s z} \vec{v}_{s} \cdot \vec{n} d A+\iint_{c s} \varepsilon_{g} \rho_{g} v_{g z} \vec{v}_{g} \cdot \vec{n} d A=\dot{m}_{g}\left(\left.v_{g z}\right|_{z=z}-\left.v_{g z}\right|_{z=z+\Delta z}\right)+\dot{m}_{s}\left(\left.v_{s z}\right|_{z=z}-\left.v_{s z}\right|_{z=z+\Delta z}\right)
$$

If there is steady state flow and the solids volume fraction is constant, then the velocity-in equals the velocity-out and the right hand side of Equation (3) is zero.

The right hand side of Equation (2) is the sum of the forces and can be expanded as follows:

$$
0=\left.\pi R^{2}\left(P_{g}+P_{s z}\right)\right|_{z=z}-\pi R^{2}\left(P_{g}+P_{s z}\right)_{z=z+\Delta z}+\tau_{g w}(2 \pi R \Delta z)+\tau_{s w}(2 \pi R \Delta z)-\left(\varepsilon_{s} \rho_{s}+\varepsilon_{g} \rho_{g}\right) \frac{g}{g_{c}}\left(\pi R^{2} \Delta z\right)
$$

In this equation, the forces acting on the control volume are gas phase pressure, solids phase pressure, gas-wall shear stress, solids-wall shear stress, gas phase weight, and solids phase weight. Dividing by $\Delta \mathrm{z}$, and taking the limit as $\Delta \mathrm{z}$ goes to zero results in:

$$
-\frac{\partial P_{s z}}{\partial z}-\frac{\partial P_{g}}{\partial z}+\frac{2 \tau_{s w}}{R}+\frac{2 \tau_{g w}}{R}-\rho_{g} \varepsilon_{g} \frac{g}{g_{c}}-\rho_{s} \varepsilon_{s} \frac{g}{g_{c}}=0
$$

The wall shear stress and body force terms are considered small for the gas phase and are ignored (Jones 1985, Picciotti, 1995), leaving Equation (5) in terms of process variables.

$$
-\frac{\partial P_{s z}}{\partial z}-\frac{\partial P_{g}}{\partial z}+\frac{2 \tau_{s w}}{R}-\rho_{s} \varepsilon_{s} \frac{g}{g_{c}}=0
$$

Equation (6) is the microscopic form of the mixture momentum balance, and a derivation of it from shell balance techniques has been provided in Appendix A.1.

Experimentally, the gas pressure drop is determined using differential pressure transducers and the weight of the bed is determined by assuming solids volume fraction deviated little from the packed state. Shear stress measurements are obtained using a shear vane and/or the new wall device. The solids pressure is the only term not measured directly. However, it is inferred by difference from the other measurements, Equation (7). Rearranging Equation (4) and neglecting gas phase wall shear stress and gas phase body force results in Equation (7).

$$
\frac{\Delta P_{s z}}{\Delta z}=-\rho_{s} \varepsilon_{s} \frac{g}{g_{c}}+\frac{4 \tau_{s w}}{D}-\frac{\Delta P_{g}}{\Delta z}
$$




\subsection{Objectives}

The objective of this research project is to experimentally quantify the solids-wall shear stress and to estimate the differential solids pressure. The shear stress is measured under a variety of aeration conditions, and this measured value is used to predict the differential solids phase pressure drop. Further, accepted methods of predicting shear stress and solids pressure in the literature are investigated. Results using predictions from these methods are compared to the experimentally obtained values. The objectives of this research are:

1. Facilitating a literature search to understand if/how shear stress and solids pressure have been measured in the past, and to understand how shear stress and solids pressure are estimated in models.

2. Experimentally measuring solids-wall shear stress as a function of solids circulation rate using the shear vane and wall probe.

3. Using solids-wall shear stress to estimate differential solids pressure by inferring it to be the residual portion of the momentum balance.

4. Independently estimating shear stress and solids pressure for packed and transitionally packed bed regimes by obtaining bed material properties and using them with bulk solids mechanics as suggested by Picciotti 1995; Mountziaris and Jackson 1990, and Jones and Leung 1985. This method is explained in detail in section $2.2 \mathrm{a}$ of this proposal.

5. Understanding the effects of operational variables on shear stress. The variables studied are listed in Chapter 5.

Further, the shear stress at the wall and the local solids volume fraction at the wall were simultaneously measured using the new wall device and a capacitance wall probe developed by Michel Louge $(1992,1995)$. Limitations of these devices are described in Chapter 6. 


\section{CHAPTER 2 LITERATURE SURVEY}

Standpipes have been in use for over 40 years (Knowlton, 1986). As a result, a large volume of material has been published regarding them. This literature survey will focus on papers utilizing the mixture momentum balance and the forces within it. Experimental measurements of these forces are of largest interest.

\subsection{Flow Regimes}

Many papers have been published that use the mixture momentum balance in their modeling efforts. In most cases the shear stress and axial solids pressure are treated differently depending on the fluidization regime of the bed. Therefore, in order to follow this work it is necessary to discuss the possible flow regimes of the standpipe.

Leung and Jones (1985) outlined two flow regimes of the standpipe, fluidized and non-fluidized regime. They further subdivided these two regimes and discussed the possibility of multiple regimes coexisting in the standpipe at the same time. Knowlton (1986) suggested a third regime, streaming flow, which is characterized by dilute phase flow with a high void fraction. This type of flow is unlikely under the conditions of this work.

Leung and Jones (1985) used slip velocity $\left(\mathrm{U}_{\mathrm{sl}}\right)$ and void fraction $(\varepsilon)$ to differentiate between the regimes. $\mathrm{U}_{\mathrm{sl}}$ is defined by the following equation:

$$
U_{s l}=\frac{-U_{g}}{\varepsilon}+\frac{U_{s}}{1-\varepsilon}
$$

The sign convention is that solid and gas velocities are positive down and $\mathrm{U}_{\mathrm{sl}}$ is positive up. Solids velocity is always down and positive. See Table 1 for clarification.

Table 1: Sign Convention for $\mathrm{U}_{\mathrm{sl}}$

\begin{tabular}{|c|c|c|c|}
\hline $\mathbf{U}_{\text {sl }}$ & $\mathbf{U}_{\mathbf{g}}$ & $\mathbf{U}_{\mathbf{s}}$ & \\
\hline Negative & Positive & Positive & $\mathrm{U}_{\mathrm{g}}>\mathrm{U}_{\mathrm{s}}$ \\
\hline Positive & Positive & Positive & $\mathrm{U}_{\mathbf{g}}<\mathrm{U}_{\mathrm{s}}$ \\
\hline Positive & Negative & Positive & \\
\hline
\end{tabular}




\section{1.a Non-Fluidized Regime}

A slip velocity less than minimum fluidization velocity and a void fraction less than minimum fluidization void fraction characterize the non-fluidized regime. See Equation (9) and (10) (Leung, 1985).

$$
\begin{aligned}
\mathrm{U}_{\mathrm{sl}} & <\left(\mathrm{U}_{\mathrm{mf}} / \varepsilon_{\mathrm{mf}}\right) \\
\varepsilon & <\varepsilon_{\mathrm{mf}}
\end{aligned}
$$

Leung and Jones further subdivided this regime into packed-bed flow and transitional packed bed flow. In both regimes $\mathrm{U}_{\mathrm{sl}}$ is negative which means that the gas is flowing down with the solids but at a greater rate. Equation (11) and (12) define packedbed flow.

$$
\begin{gathered}
\mathrm{U}_{\mathrm{sl}}<0 \\
\varepsilon=\varepsilon_{\mathrm{c}}
\end{gathered}
$$

$\varepsilon_{\mathrm{c}}$ is the vibrated void fraction. Transition packed-bed flow is defined by Equations (13) through (15)

$$
\begin{aligned}
0>\mathrm{U}_{\mathrm{sl}} & <\left(\mathrm{U}_{\mathrm{mf}} / \varepsilon_{\mathrm{mf}}\right) \\
\varepsilon_{\mathrm{c}} & <\varepsilon<\varepsilon_{\mathrm{mf}} \\
\varepsilon & =\varepsilon\left(\mathrm{U}_{\mathrm{sl}}\right)
\end{aligned}
$$

Equation (15) means that void fraction is a function of the slip velocity for transition packed-bed flow, and it is defined to be constant for packed-bed flow.

\section{1.b Fluidized Regime}

The fluidized regime is characterized by a slip velocity equal to or greater than the minimum fluidization velocity and a void fraction equal to or greater than the minimum fluidization void fraction (Leung, 1985). See Equation (16) and (17).

$$
\begin{aligned}
\mathrm{U}_{\mathrm{sl}} & >\left(\mathrm{U}_{\mathrm{mf}} / \varepsilon_{\mathrm{mf}}\right) \\
\varepsilon & >\varepsilon_{\mathrm{mf}}
\end{aligned}
$$

This regime is further subdivided into type I fluidized flow and type II fluidized flow. Type I fluidized flow is defined by Equation (18) and (19), and type II fluidized flow is defined by Equation (20) and (21). 


$$
\begin{gathered}
\left(\frac{\partial U_{g}}{\partial \varepsilon}\right)_{U_{s}}>0 \\
U_{s l}>\frac{U_{m f}}{\varepsilon_{m f}} \\
\left(\frac{\partial U_{g}}{\partial \varepsilon}\right)_{U_{s}}<0 \\
U_{s l}>\frac{U_{m f}}{\varepsilon_{m f}}
\end{gathered}
$$

Knowlton (1986) divided the fluidized regime into bubbling fluidized flow and non-bubbling fluidized flow. He further divided bubbling flow into four regimes:

- Type 1. Emulsion gas flow up, bubble flow up, net gas flow up

Both the gas flowing in the interstices and the bubbles are flowing up relative to the standpipe wall. This occurs when the velocity of the solids is less than the minimum fluidization velocity.

- Type 2. Emulsion gas flow down, bubble flow up, net gas flow up

In this classification the velocity of the solids is greater than minimum fluidization velocity. Therefore, the gas flowing in the interstices is flowing down. However, the bubble rise velocity is greater than the solids velocity. Because the volumetric flow rate of the bubbles is greater than the volumetric flow rate of the gas in the interstices, the net flow of gas is up.

- Type 3. Emulsion gas flow down, bubble flow up, net gas flow down

This regime is very similar to type 2 because the solids velocity is greater than the minimum fluidization and less than the bubble velocity. However, because the volumetric flow rate of the bubbles is less than the volumetric flow of the gas in the interstices, the net gas flow is down.

- Type 4. Emulsion gas flow down, bubble flow down, net gas flow down.

In this case the solids velocity is greater than the bubble rise velocity. Therefore, the bubbles are carried down at a velocity of equal to the difference between the solids velocity and the bubble rise velocity. 


\subsection{Standpipe Modeling}

In general, researchers use different relationships depending on the flow regime of the standpipe. This is especially common in the treatment of solids wall shear stress and solids pressure. Most researchers model all components of their system such as hoppers feeding the system and valves discharging solids from the system. They also include boundary conditions for transitions between each component, and for each component there is generally a set of equations used, such as a mass and momentum balance. In this work the standpipe will be the only component under consideration, and the mixture momentum balance will be the emphasis. It is also important to note that only steady flow is considered in this work. The mixture momentum balances for each flow regime will be discussed.

\section{2.a Non-Fluidized Regime}

Researchers have recognized the importance of solids-wall shear and solids pressure for non-fluidized regimes. Bulk solids mechanics has been introduced to estimate these forces. In general, the form of the mixture momentum balance used is Equation (6), and is rewritten below (Picciotti 1995; Leung and Jones 1985).

$$
-\frac{\partial P_{s z}}{\partial z}-\frac{\partial P_{g}}{\partial z}+\frac{2 \tau_{s w}}{R}-\rho_{s} \varepsilon_{s} \frac{g}{g_{c}}=0
$$

Picciotti (1995) and Leung and Jones (1985) suggest substituting a relationship that relates solids shear stress to axial solids pressure into this equation. This relationship comes from bulk solids mechanics and is summarized by Equation (22) through (24).

$$
\begin{gathered}
\tau_{\mathrm{sw}}=\mu_{\mathrm{w}} \mathrm{P}_{\mathrm{sr}} \\
\mu_{\mathrm{w}}=\tan \delta_{\mathrm{w}} \\
P_{s r}=P_{s z} \frac{1-\sin \delta}{1+\sin \delta}
\end{gathered}
$$

Substituting Equation (23) and (24) into Equation (22) gives Equation (25).

$$
\tau_{s w}=\tan \delta_{w} \frac{1-\sin \delta}{1+\sin \delta} P_{s z}
$$

The constants $\delta_{\mathrm{w}}$ and $\delta$ are the angle of wall friction and the effective internal angle of friction respectively. Note Equation (26), and that $1 / \mathrm{K}$ is the Janssen coefficient and $\mu_{\mathrm{w}}$ 
in Equation (23) is the coefficient of friction. (Jones, 1985; Picciotti, 1995; Mountziaris, 1990; and Schulze, 2000).

$$
\frac{1}{K}=\frac{1-\sin \delta}{1+\sin \delta}
$$

Substituting Equations (26) and (23) into (25) results in Equation (27).

$$
\tau_{s w}=\frac{\mu_{w}}{K} P_{s z}
$$

The previous expression can be substituted into the mixture momentum balance, if the bed is assumed to be in an active state of stress and packed. An active state of stress implies that the major principal stress is in the z-direction, and the corresponding minor principal stress is in the rdirection. This means that the solids are on the verge of compacting in the axial direction and expanding in the horizontal direction (Mountziaris, 1990).

Picciotti (1995) makes this suggested substitution and derives Equation (28) assuming a constant pressure drop per unit length and a boundary condition of zero solids pressure at the top of the bed. Take note that the coordinate system that Picciotti used in the derivation of Equation (28) is the opposite of that used in this work. He used a positive z-axis pointing down. The complete derivation of Equation (28) can be found in Appendix A.2a.

$$
P_{s z}=\frac{R K}{2 \mu_{w}}\left[\rho_{s} \varepsilon_{s} \frac{g}{g_{c}}+\frac{\Delta P_{g}}{H}\right]\left[1-e^{\frac{-2 \mu_{w} z}{R K}}\right]
$$

The total pressure drop across the standpipe (pressure at the top minus pressure at the bottom, which should be a negative value) is $\Delta \mathrm{P}$, and the height of the bed in the standpipe is $\mathrm{H}$. The location of the estimation of solids pressure measured down from the top of the bed is $\mathrm{z}$.

Mountziaris and Jackson (1990) use essentially the same theory, except the individual gas phase momentum balance and solids phase momentum balance are modeled rather than the mixture balance. The same relationship between solids shear stress and solids pressure is utilized. A summary of the approaches to modeling solidswall shear stress for non-fluidized regimes is supplied in Table 2. 
Table 2 : Modeling Solids-Wall Shear Stress for Non-Fluidized Regime

\begin{tabular}{|c|c|c|}
\hline Reference & Fluidization Regime & Wall Shear Stress \\
\hline Leung and Jones, 1985 & Packed-Bed Flow & $\tau_{s w}=\tan \delta_{w} \frac{1-\sin \delta}{1+\sin \delta} P_{s, z}$ \\
\hline Leung and Jones, 1985 & Transition Packed-Bed Flow & $\tau_{s w}=\tan \delta_{w} \frac{1-\sin \delta}{1+\sin \delta} P_{s, z}$ \\
\hline Mountziaris and Jackson, 1990 & Moving Bed Flow & $\tau_{s w}=\tan \delta_{w} \frac{1-\sin \delta}{1+\sin \delta} P_{s, z}$ \\
\hline Picciotti, 1995 & Packed-Bed Flow & $\tau_{s w}=\tan \delta_{w} \frac{1-\sin \delta}{1+\sin \delta} P_{s, z}$ \\
\hline
\end{tabular}

\section{2.b Fluidized Regime}

Unlike non-fluidized regimes where researchers appear to be in agreement in their consideration of solids shear stress, there are varying opinions regarding solids-wall shear stress for fluidized regimes. Leung and Jones (1985) state that for fluidized flow the solids pressure is zero, and they suggest using a friction factor to express shear stress. Leung and Wiles (1976) list various correlations for the friction factors, but Leung and Jones (1985) suggest that for a dense-phase flow with voidage close to that of minimum fluidization the friction factor is constant and can be approximated by $f=0.003$. Leung and Wiles (1976) cite Stermerding (1962) for this constant friction factor. Stermerding (1962) studied pneumatic transport and back calculated friction factors from slip factors that are calculated from pressure drop, gas velocity and solids mass velocity. Mountziaris and Jackson (1990) assume solids-wall shear stress and solids pressure to be negligible for suspension flow. A summary of the approaches to modeling solids-wall shear stress for non-fluidized regimes is supplied in Table 3. 
Table 3: Modeling Solids -Wall Shear Stress for Fluidized Regimes

\begin{tabular}{|c|c|c|}
\hline Reference & Fluidization Regime & Wall Shear Stress \\
\hline Leung and Jones, 1985 & $\begin{array}{c}\text { Type I and Type II } \\
\text { Fluidized Flow }\end{array}$ & $\tau_{w}=\frac{1}{2} f \varepsilon_{s} \rho_{s} u_{s}^{2 *}$ \\
\hline Knowlton, 1986 & Fluidized flow & negligible \\
\hline Mountziaris and Jackson, 1990 & Suspension Flow & negligible \\
\hline
\end{tabular}

*'For dense-phase flow with voidage close to $\varepsilon_{\mathrm{mf}}$, the contribution of wall friction is small and a constant value of $\mathrm{f}=0.003$ may be used."

\subsection{Standpipe Experimental Studies of Solids Pressure and Solids Friction}

The section above discussed modeling solids-wall shear stress and solids pressure. The purpose of this section is to discuss attempts to experimentally measure shear stress and solids pressure.

\section{3.a Solids-Wall Shear Stress}

Van Swaaij (1970) measured the solids-wall shear stress directly of cracking catalyst in a 7-inch riser. The measurements were taken using a moveable section of wall in the riser. The total force on this moveable wall was measured, and the shear stress values were taken from these measurements. See Figure 2 for details.

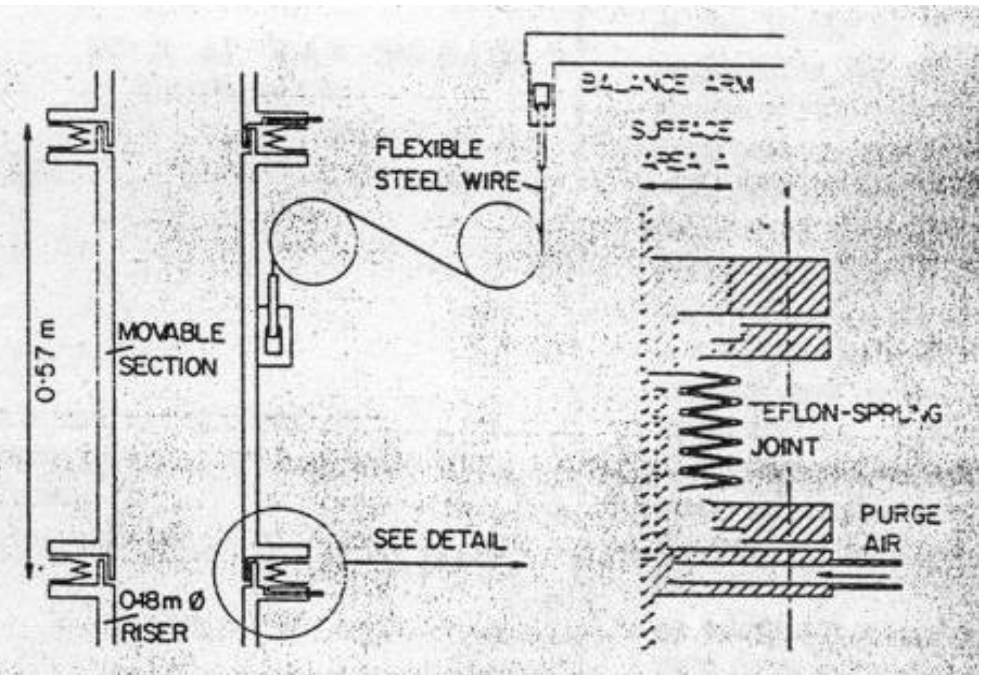

Figure 2: Moveable Wall Device for Solids -Wall Shear Stress (Van Swaaij, 1970) 
Results are shown in Figure 3. Notice that shear stress increases with solids flux. Notice the sign change in the shear stress values. At higher solids fluxes the shear stress is in the opposite direction of the gas flow due to down flow of solids at the wall.

Van Swaaij (1970) also measured average density of the flow using $\gamma$-ray adsorption. He compared density versus the gas pressure drop. See Figure 4 where $\rho s$ is the particle density and $\alpha$ is the mean solids volume fraction measured. At lower densities the pressure drop was larger than the weight of the bed, and at higher densities the pressure drop was lower than the weight of the bed.

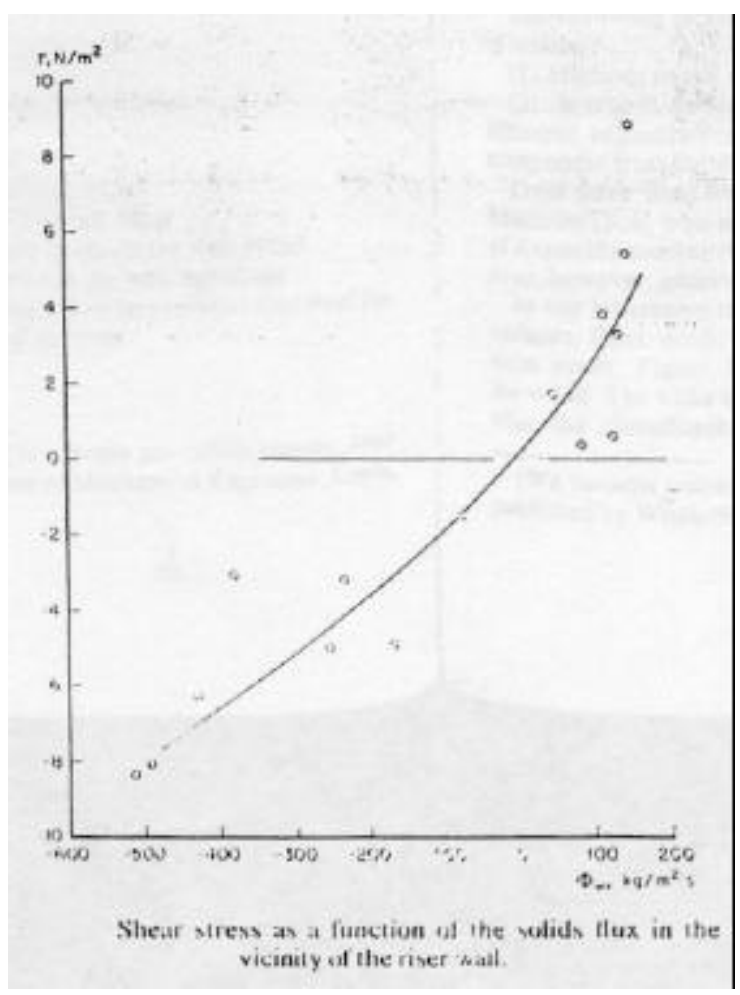

Figure 3: Shear Stress versus Solids Flux in a Pneumatic Riser (Van Swaaij,

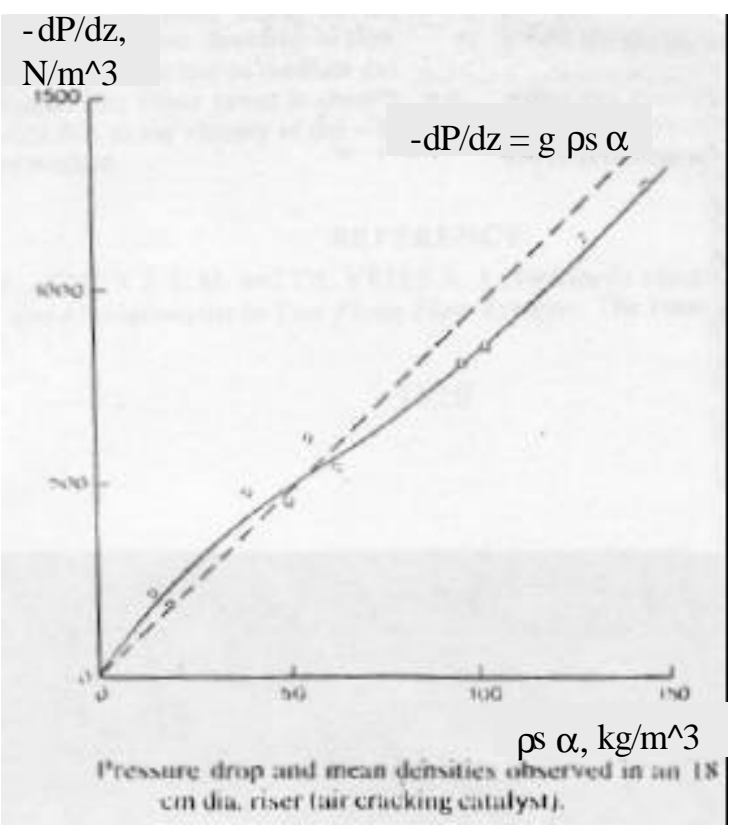

Figure 4: Pressure Drop and Mean Densities (Van Swaaij, 1970)

Table 4 gives the raw data listed by Van Swaaij. The percentage of the total forces cannot be evaluated since density measurements were not given along with shear stress measurements. $\Phi_{\mathrm{w}}$ is the solid flux in the vicinity of the wall in units of $\mathrm{kg} / \mathrm{m}^{2} \mathrm{sec}$. 
Table 4: Riser Conditions and Shear Stress (Van Swaaij, 1970)

\begin{tabular}{|c|c|c|c|c|c|c|}
\hline $\begin{array}{c}\text { Mean gas } \\
\text { Velocity } \\
\text { (m/sec) }\end{array}$ & $\begin{array}{c}\text { Mean } \\
\text { solids flux } \\
\left.\text { (kg/m } / \mathrm{m}^{2} \text { sec }\right)\end{array}$ & $\boldsymbol{\Phi}_{\mathbf{w}}$ & $\begin{array}{c}\mathbf{F} \\
(\mathbf{N})\end{array}$ & $\begin{array}{l}\mathbf{d p} / \mathbf{d z} \\
\left(\mathrm{N} / \mathbf{m}^{3}\right)\end{array}$ & $\begin{array}{c}\tau \\
\left(\mathbf{N} / \mathbf{m}^{2}\right)\end{array}$ & $\begin{array}{c}\text { Contribution } \\
\text { of shear to } \\
\text { pressure } \\
\text { drop }(\%)\end{array}$ \\
\hline 4.7 & 133 & -430 & 4.1 & 844 & -6.3 & -16 \\
\hline 4.3 & 141 & -167 & 6.3 & 1090 & -4.9 & -10 \\
\hline 6.0 & 206 & -497 & 3.3 & 818 & -8.1 & -22 \\
\hline 5.7 & 344 & -511 & 6.2 & 1238 & -8.4 & -15 \\
\hline 8.5 & 236 & -76 & 3.0 & 477 & -1.5 & -7 \\
\hline 7.6 & 385 & -255 & 6.2 & 1078 & -5.0 & -10 \\
\hline 8.5 & 432 & -384 & 6.7 & 1062 & -3.1 & -6 \\
\hline 10.0 & 152 & 85 & 1.7 & 215 & 0.4 & 4 \\
\hline 9.4 & 284 & -49 & 3.0 & 492 & -1.7 & -7 \\
\hline 12.2 & 316 & 126 & 2.8 & 355 & 0.6 & 4 \\
\hline 11.0 & 514 & -236 & 4.1 & 705 & -3.2 & -10 \\
\hline 14.9 & 183 & 118 & 2.9 & 231 & 3.8 & 36 \\
\hline 15.1 & 213 & 132 & 2.8 & 229 & 3.3 & 31 \\
\hline 13.3 & 419 & 143 & 5.4 & 501 & 5.4 & 23 \\
\hline 13.06 & 434 & 150 & 7.0 & 560 & 8.8 & 34 \\
\hline
\end{tabular}

standpipes by the difference between the density of the bed and the gas phase pressure drop per unit length. The density of the bed was measured using the attenuation of gamma radiation. He found that the friction loss due to solids-wall contact increases dramatically as the density of the bed increases, Figure 5. Raw data for large commercial units published by Matsen (1976) is listed in Table 5. Notice that the friction loss increases sharply as the density of the bed increases. 


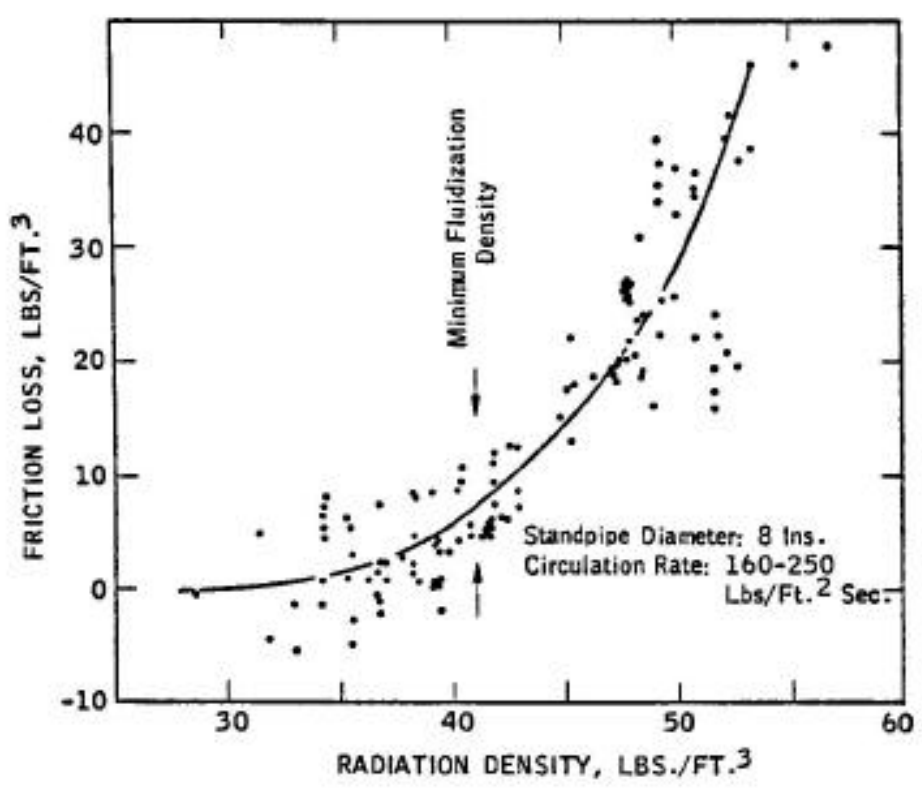

Friction loss in standpipe.

Figure 5: Solids-Wall Friction Versus Density of the Bed (Matsen, 1976)

Table 5: Commercial Data on Solids-Wall Friction (Matsen, 1976)

\begin{tabular}{|c|c|c|c|c|c|}
\hline $\begin{array}{l}\text { Diameter } \\
\text { Inches }\end{array}$ & Material & $\begin{array}{c}\text { Mass Rate } \\
\text { lb/fitsec }\end{array}$ & $\begin{array}{c}\text { Radiation Density } \\
\underline{\mathrm{lb} / \mathrm{ft}^{3}}\end{array}$ & $\underset{\mathbf{l b} / \mathbf{f t}^{3}}{\Delta \mathrm{P} / \mathbf{L}}$ & $\begin{array}{c}\text { Friction } \\
\mathrm{lb} / \mathrm{ft}^{3}\end{array}$ \\
\hline 23 & coke & 75 & 61 & 31 & 30 \\
\hline 23 & coke & 75 & 65 & 20 & 45 \\
\hline 29 & catalyst & 145 & 42 & 38 & 4 \\
\hline 29 & catalyst & 145 & 49 & 36 & 13 \\
\hline 30 & catalyst & 160 & 54 & 39 & 15 \\
\hline 33 & coke & 37 & 60 & 55 & 5 \\
\hline 42 & catalyst & 115 & 47 & 41 & 6 \\
\hline 42 & catalyst & 115 & 53 & 32 & 19 \\
\hline 42 & catalyst & 115 & 55 & 21 & 34 \\
\hline 50 & catalyst & 200 & 39 & $40.5+/-4.5$ & -1.5 \\
\hline 50 & & & 42 & $40.5+/-4.5$ & 1.5 \\
\hline 50 & & & 37 & $40.5+/-4.5$ & -3.5 \\
\hline
\end{tabular}

Matsen's estimation of solids-wall friction ranged from $2 \%$ to as high as $35 \%$ of

the total forces studied. The forces he included are weight of the bed, gas phase pressure drop per unit length, and shear stress. His estimations of shear stress may be elevated because solids phase pressure drop per unit length has not been included. In this study, shear stress has been estimated over a mass circulation ramp that ranged from 3,000 to $43,000 \mathrm{lb} / \mathrm{hr}$ to range from $27 \%$ to $6 \%$ of the total forces. The forces considered in this 
study are the weight of the bed, gas phase pressure drop $\left(-\Delta \mathrm{P}_{\mathrm{g}} / \mathrm{L}\right)$, solids phase pressure $\operatorname{drop}\left(-\Delta \mathrm{P}_{\mathrm{s}} / \mathrm{L}\right)$, and shear stress $\left(-2 \tau_{\mathrm{sw}} / \mathrm{R}\right)$.

It is difficult to compare the commercial data with data collected in this study, because the commercial data was taken under different conditions. The standpipe diameters are over wice as large as the standpipe used in this work. The data for the commercial units are taken at higher temperatures and pressures than ambient. The unit used in this work is a cold flow unit, which runs at ambient temperatures and close to atmospheric pressure. Further, aeration schemes in Matsen's work are not noted, so operating conditions are not clear. One commonality is one of the bed materials. Coke is used in both studies. The mass fluxes of Matsen's study are larger to those of this study. Matsen's study ranged from 37 to $200 \mathrm{lb} / \mathrm{ft}^{2} \mathrm{sec}$ and fluxes of this study have ranged from 1.5 to $2.2 \mathrm{lb} / \mathrm{ft}^{2}$ sec. Further, due to the large differences in the standpipe diameters the circulation rates of the commercial units are up to four times higher. Another difference was that the commercial data reported in Matsen's study was taken from standpipes that were operating with a poor pressure rise. (Matsen, 1976). The desired pressure drop across the standpipe was not achieved, leading to instabilities in the system.

Zenz (1960) estimated solids wall shear stress for packed and fluidized conditions with the use of a tube-pulling apparatus. See Figure 6 for a schematic of the device. A fixed piston and the tube wall support the bed material. A water-filled balloon is placed at the bottom of the bed material and, the pressure exerted on this balloon is measured. An aeration ring is also placed at bottom of the bed material for fluidized conditions. A hand crank pulls the tube. The tube velocity was measured using the analysis of highspeed motion photography. Zenz (1960) estimated the shear stress to be the difference between the pressure exerted at the bottom of the bed when tube is stationary and when the tube is in motion.

Zenz (1960) found that for fluidized conditions the difference was negligible regardless of the velocity of the tube. However, for packed condition the difference decreased with increasing tube velocity. See Figure 7 for experimental results. Notice that similar results were found for $3 \frac{1}{2}$ and $5 \frac{1}{2}$ diameter tubes. His results give values ranging from $4-3.5$ to $4-0.5 " \mathrm{H}_{2} \mathrm{O}$ which corresponds to 2.6 to $18.2 \mathrm{lb} / \mathrm{ft}^{2}$. His upper end of the range is much higher then what has been seen in this study, 1.74 to $7.2 \mathrm{lb} / \mathrm{ft}^{2}$. 


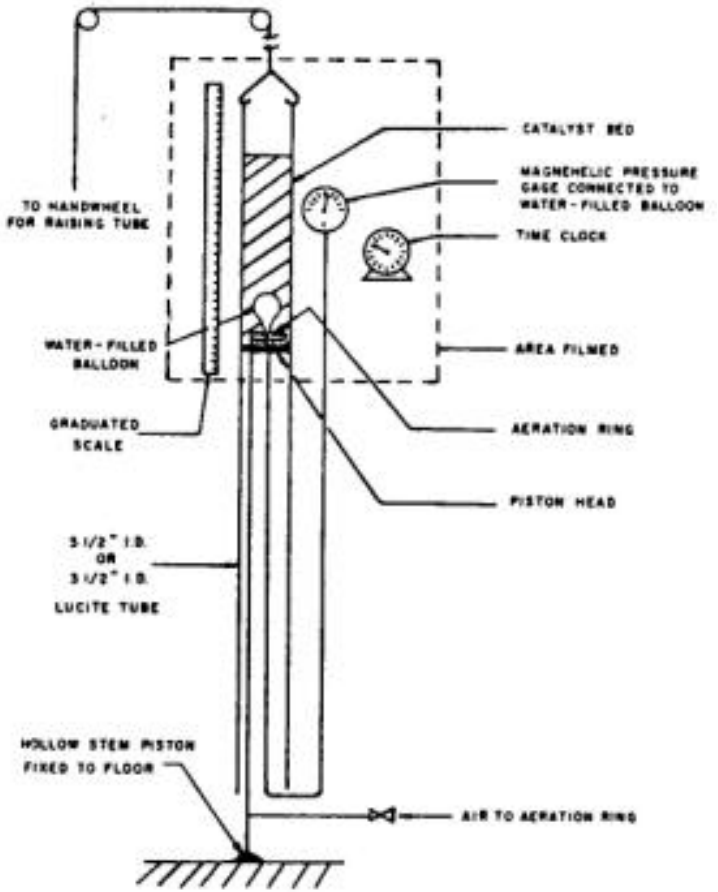

Figure 6: Tube-Pulling Apparatus (Zenz, 1960)

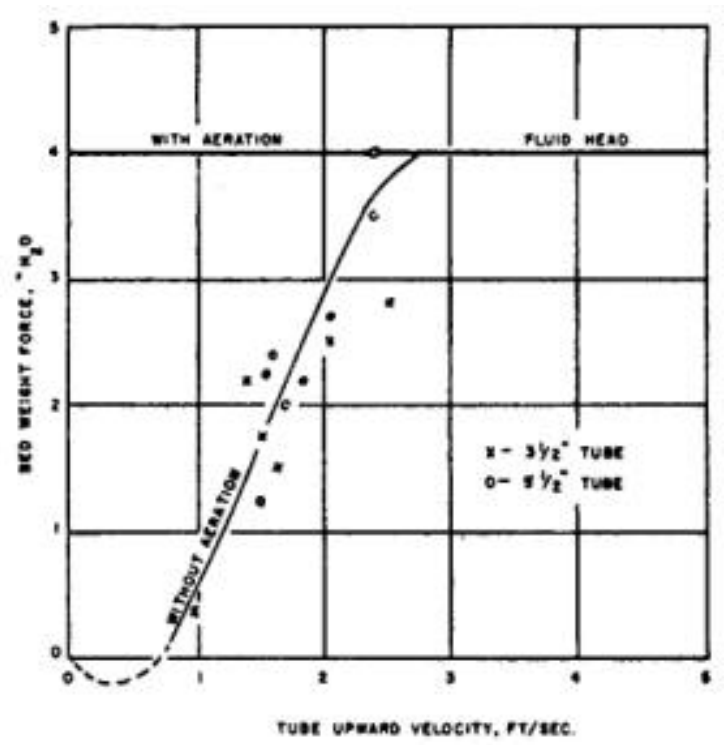

Figure 7: Tube-Pulling Experimental Results (Zenz, 1960)

\section{3.b Solids Pressure}

Polashenski (1999) measured local time-averaged solids pressure in the riser of a CFB. The measurements were taken internally and at the wall for both dilute and dense beds. Polashenski's device is illustrated in Figure 8. A diaphragm, which is in contact with the solids and gas, is mounted flush with a sensitive transducer. A screened vent tube is connected to the rear of the probe to allow the gas to equalize on both sides of the diaphragm. The net response of the diaphragm is due to solids pressure in the radial direction only. Solids fraction was also measured using a capacitance probe. Two bed materials were studied which were sand (Geldart Group B $d_{p}=140 \mu \mathrm{m}, \rho_{\mathrm{s}}=2500 \mathrm{~kg} / \mathrm{m}^{3}$ ) and FCC (Geldart Group A d $d_{p}=94 \mu \mathrm{m}, \rho_{\mathrm{s}}=1500 \mathrm{~kg} / \mathrm{m}^{3}$ ). 

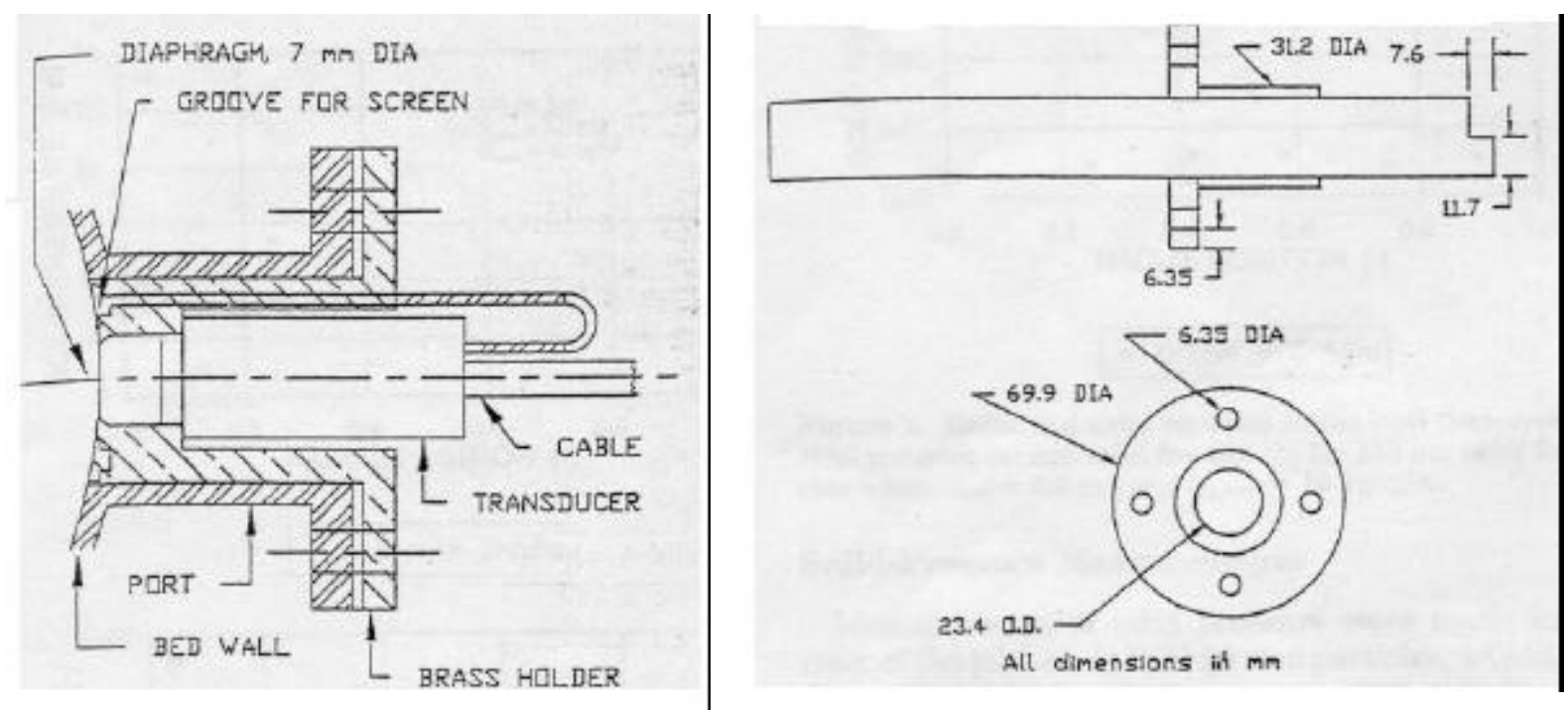

Figure 8: Solids Pressure Probes (Polashenski, 1999)

Polashenski (1999) found that the strongest correlating factor for local timeaveraged solids pressure is solids volume fraction. See Figure 9 for experimental data. Solids pressure is essentially constant for low solids fraction. However, after a solids fraction of approximately 0.05 the local time-averaged solids pressure increases with increasing solids fraction. Polashenski (1999) gave a relationship for this correlation, Equation (29).

$$
P_{s, r}=\left[\left(16.5 \varepsilon_{s}^{0.1}\right)^{5}+\left(518 \varepsilon_{s}^{1.1}\right)^{5}\right]^{0.2}
$$

$\mathrm{P}_{\mathrm{s}, \mathrm{r}}$ is in units of $\mathrm{Pa}$. 


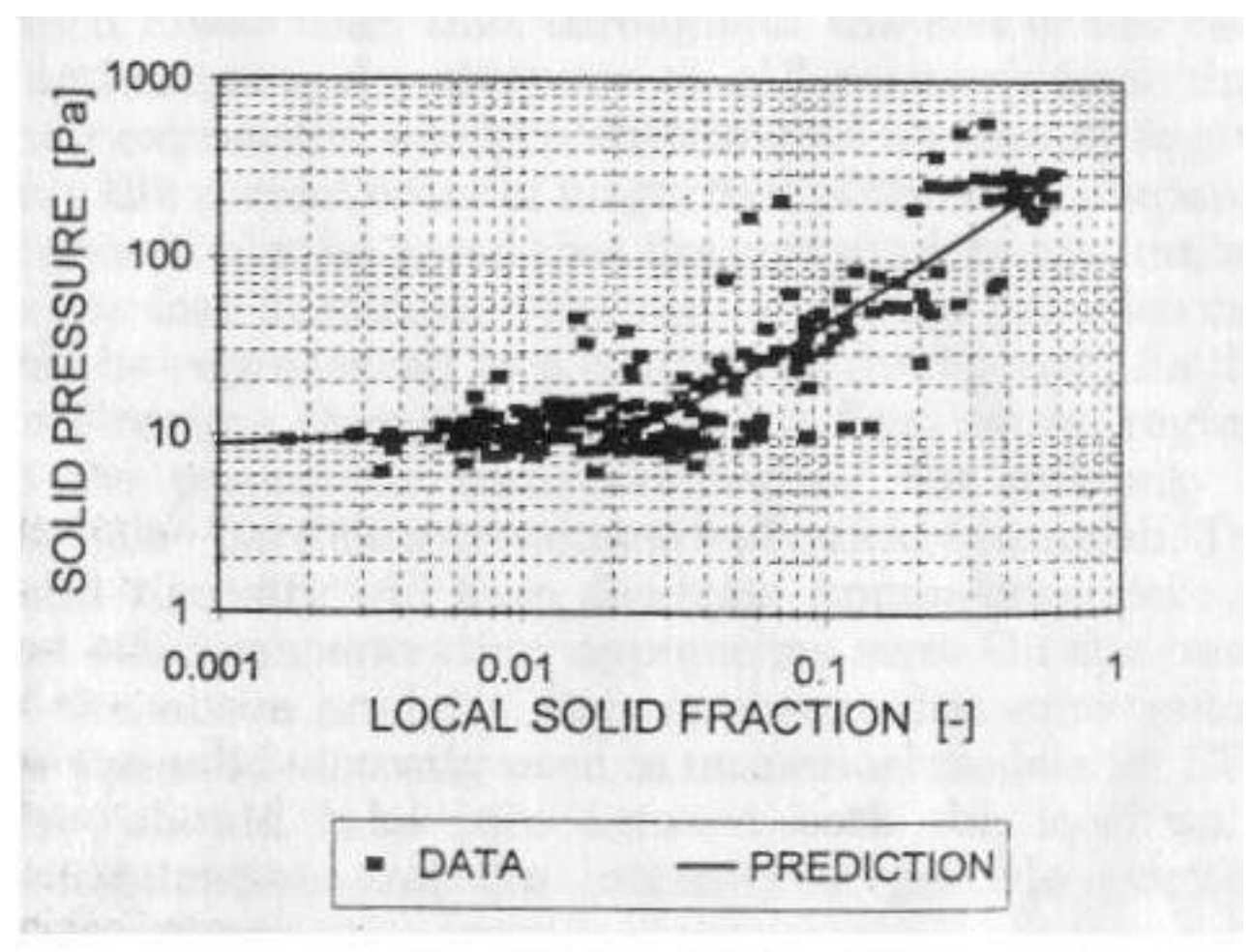

Figure 9: Solids Pressure versus Local Solid fraction (Polashenski, 1999)

Since the solids pressure measurements taken under Polashenski's study are in the radial direction and in the riser of the $\mathrm{CFB}$, they are several orders of magnitude less than our estimated pressures. For example, solids pressure ranged from 10 to $300 \mathrm{~Pa}$, which corresponds to 0.209 to $6.27 \mathrm{lb} / \mathrm{ft}^{2}$ for Polashenski's study. In this study, solids pressure was estimated to range from 86 to $143 \mathrm{lb} / \mathrm{ft}^{2}$. Also, we are operating in a packed bed state. Polashenski operated in the more dilute CFB riser. 


\section{CHAPTER 3 EXPERIMENTAL SET-UP}

\subsection{Circulating Fluid Bed}

The circulating fluidized bed (CFB) under study is located at the National Energy Technology Lab located in Morgantown, WV. The size of the CFB is large for an experimental system. The riser is 12 " ID with $50 \mathrm{ft}$ height, and the standpipe is 10" ID. A nominal rate of $40,000-\mathrm{lb} / \mathrm{hr}$ circulation of solids (coke breeze) can be attained. The system is rated at $100 \mathrm{psi}$, but most of the tests for this study were carried out at atmospheric pressure and ambient temperature. The standpipe and riser are equipped with pressure transducers along their length. Mass flow controllers are used to supply aeration. Solids are transported from the standpipe to the riser through a loopseal, which is a nonmechanical valve. The standpipe and loopseal are equipped with pressure transducers and aeration ports. Solids are collected coming out of the riser and returned to the standpipe through a primary cyclone. A schematic of the CFB is in Figure 10. Circles denote location of pressure transducers. Arrows pointing toward the vessel walls indicate aeration ports. One particular aeration port of importance is located at $0.3^{\prime}$ on the diagram. This aeration controls solids circulation rate, and is referred to as move air, $\mathrm{F}_{\mathrm{m}}$. 


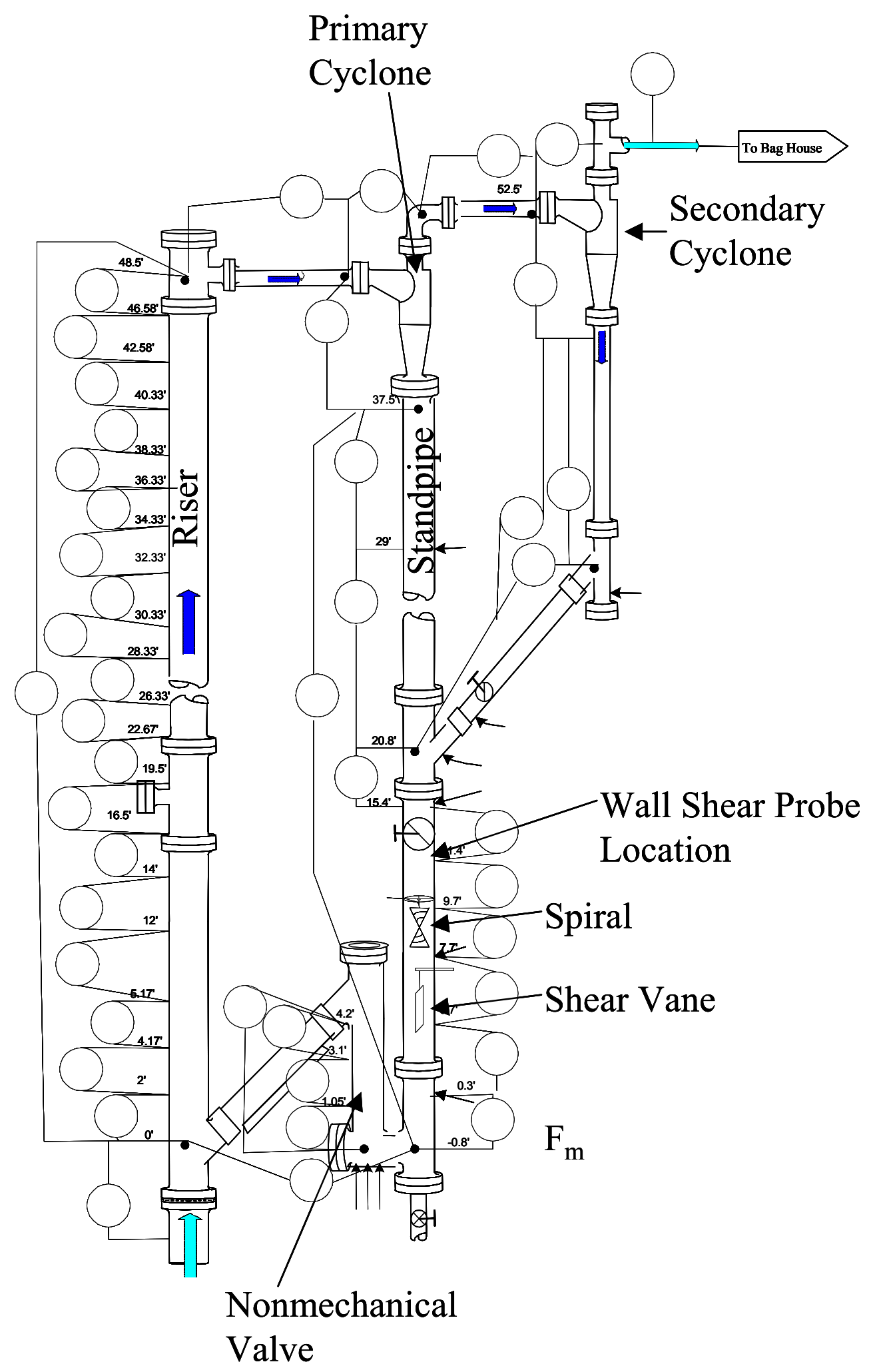

Figure 10: NETL Circulating Fluid Bed 


\subsection{Bed Materials and Properties}

The materials utilized in this study are coke breeze and cork.

Coke breeze is a Geldart group B (Gidaspow, 1994) with an average particle diameter of 230 micron. Its bulk density is 49 to $55 \mathrm{lb} / \mathrm{ft}^{3}$ with a particle density of 110.8 $\mathrm{lb} / \mathrm{ft}^{3}$. Particle density is measured using a water displacement technique similar to the discussion in Section 3.6c. Solids volume fractions under vibrated and minimum fluidization conditions were measured as 0.50 and 0.445 , respectively. These measurements were obtained by measuring the bulk density under vibrated and minimum fluidization conditions and using the above particle density. The minimum fluidization velocity is $0.072 \mathrm{ft} / \mathrm{sec}$ with a sphericity of 0.84 . Sphericity was calculated using the Ergun equation. From Jenike shear cell measurements, the internal angle of friction of the new material has been estimated to be 33.57 to $43.87^{\circ}$, and angle of wall friction associated with galvanized sheet metal (shear vane) was estimated to be $18^{\circ}$. The angle of wall friction associated with painted carbon steel (Phenalic Resin) was estimated to be $24^{\circ}$. All carbon steel parts of the NETL CFB are painted with phenalic resin. A full description of the measurement techniques and the full meaning of these angles can be found in A.3.

Cork is a Geldart group B (Gidaspow, 1994) with an average particle diameter of 1,000 micron. Its bulk density is 5.5 to $6.7 \mathrm{lb} / \mathrm{ft}^{3}$ with an intrinsic density of $13 \mathrm{lb} / \mathrm{ft}^{3}$. Solids volume fractions under vibrated and fluffed conditions were measured as 0.515 and 0.423 , respectively. The minimum fluidization velocity is $0.555 \mathrm{ft} / \mathrm{sec}$. Utilizing the technique of Zenz (1960), the internal angle of friction of the new material has been

estimated to be $74.3^{\circ}$, and angle of wall friction associated with galvanized sheet metal (shear vane) was estimated to be $37.2^{\circ}$.

\subsection{Description of Mass Flow Device}

A spiral device developed by NETL is placed at approximately 8-9' in the standpipe and is used to measure mass circulation. As the solids pass by this spiral, the solids force it to rotate. The speed of this rotation is measured and gives a volumetric flow rate. This volumetric flow rate is converted to mass circulation using the bulk 
density (Ludlow, 2002). Take note that the void fraction is assumed to be constant. A picture of the spiral is shown in Figure 11.

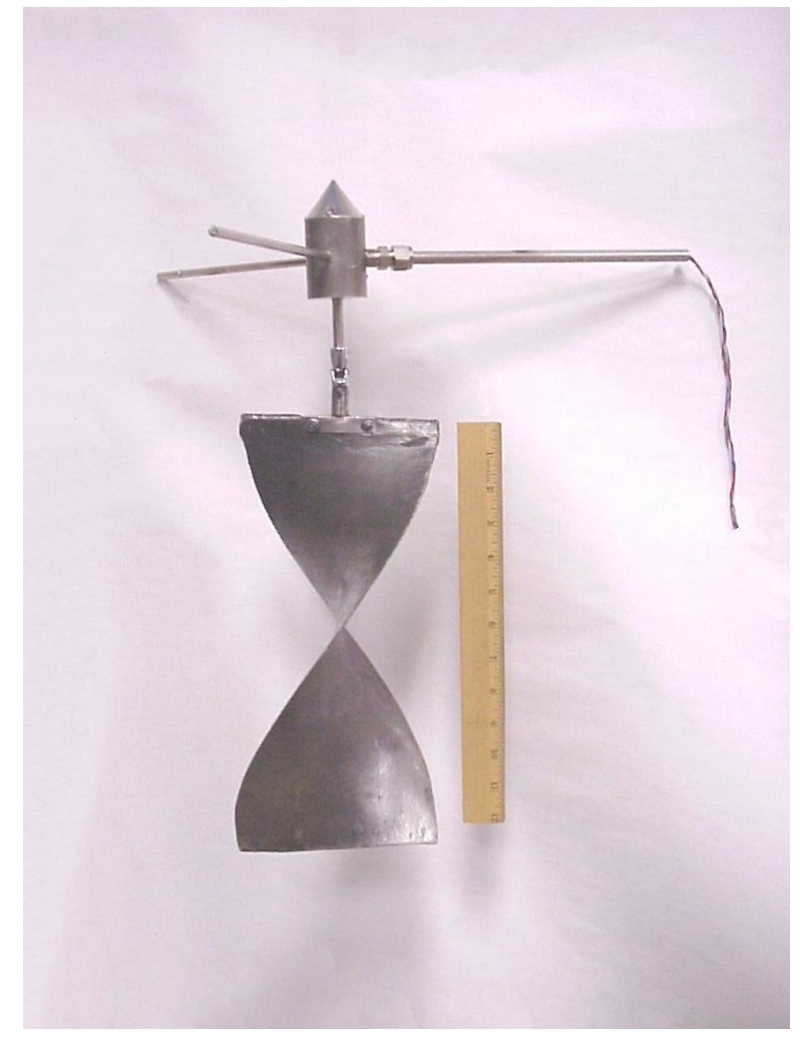

Figure 11: Spiral, Mass Circulation Measurement

\subsection{Shear Vane}

\section{4a Shear Vane General Description}

The shear vane is a device used to measure shear stress within the standpipe, developed concurrently by WVU and NETL. It is a thin, flat metal sheet suspended from a $10 \mathrm{lb}$ load cell probe. The load cell measures the weight of the vane plus the forces the bed particles exert on it as they move past it. The vane hangs along the centerline of the standpipe. The top of the vane is located about 7.7 feet from the bottom of the standpipe. The vane is 3 inch in width, 24 inch in length, and 1/32 inch in thickness (Figure 16). The active area of the shear vane is $1 / 5^{\text {th }}$ the surface area of the same length of 10 " pipe. It is assumed that the shear stress measured by the vane along the centerline of the pipe is the same as the shear stress at the wall. This is a reasonable assumption if we assume plug flow in the standpipe or radial variation in shear stress. 


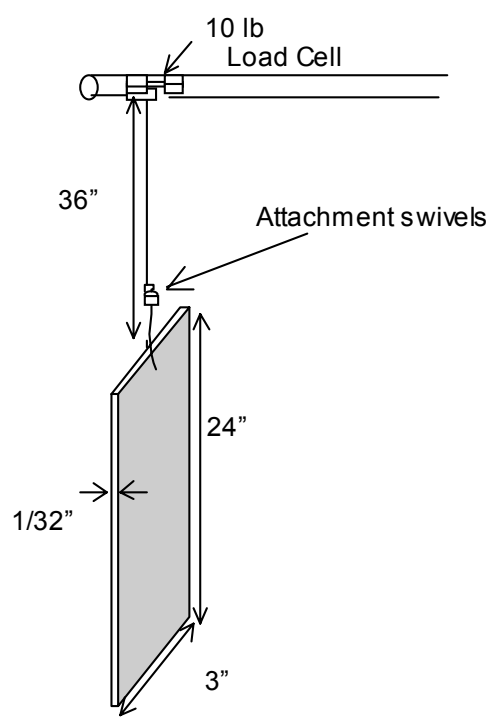

Figure 12: Shear Vane Schematic

\section{4b Shear Vane Calibration and Error}

To calibrate the shear vane, twelve weights, that span the force expected for coke breeze, were applied first in an increasing manner followed by a decreasing manner. The results are in Figure 13. Based on the variability in Figure 13, the error associated with the shear vane is $\pm 0.14 \mathrm{lb} / \mathrm{ft}^{2}$ for a $\pm 2 \mathrm{~s}$ limits (Doebelin, 1983). This corresponds to a $2 \%$ of scale for coke breeze and a $6 \%$ of scale for cork.

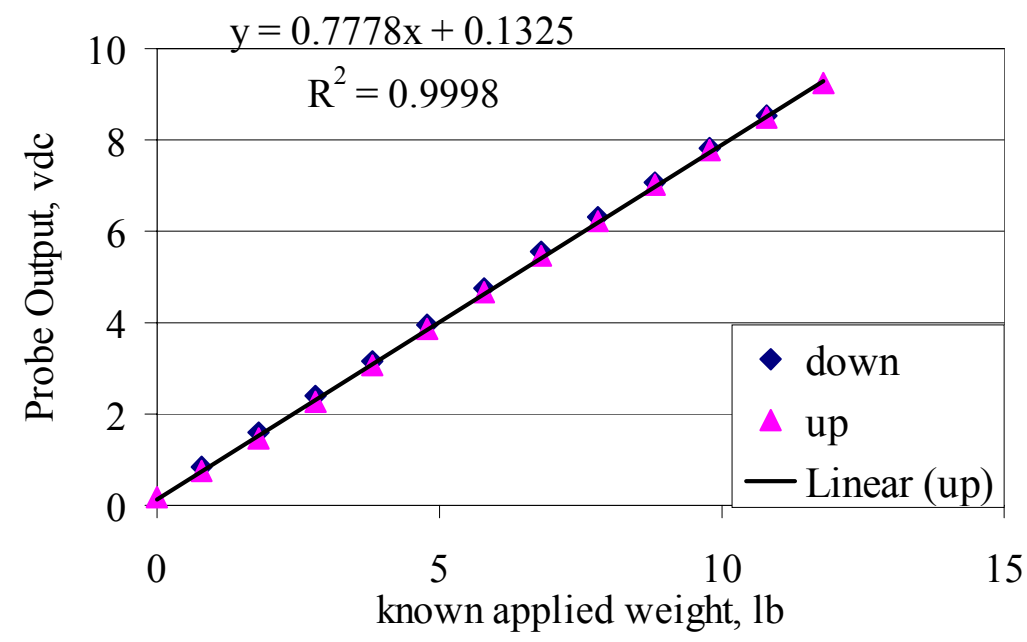

Figure 13: Shear Vane Calibration 


\section{4c Parasitic Drag Characterization}

It was mentioned above that the shear vane measures the weight of the vane and the forces the bed particles exert on it as they move past it. Unfortunately other forces are measured such as the drag associated with the leading edge of the metal vane and drag along the cable. These forces are referred to as parasitic drag. The purpose of this section is to describe the test and results used to characterize the parasitic drag.

In this experiment the vane length and mass circulation was varied, and the response variables were the force measured by the vane and the pressure drop across the interval that contained the vane. The aeration to the riser and loopseal were held constant. The aeration, referred to as move air $\left(\mathrm{F}_{\mathrm{m}}\right.$ in Figure 10) was changed to obtain desired mass circulation rates. The pressure drops across the riser, standpipe, and loopseal were monitored at all times.

Two tests were performed. First, a steady state analyses was made with two different mass circulation rates for three different lengths of otherwise identical metal shear vanes. The levels of vane lengths and mass circulation rates are in Table 6. Under the steady state analyses, the standpipe height was held constant. In the second test the move air was increased from $55 \mathrm{scfh}$ to $405 \mathrm{scfh}$ at a rate of $20 \mathrm{scfh} / \mathrm{min}$ for each vane length. Take note that under the second test the standpipe height was not constant.

Table 6: Independent Variable Levels for the Parasitic Drag Test

\begin{tabular}{|c|c|c|}
\hline Index & A & B \\
\hline No. & $\begin{array}{c}\text { Mass Circulation } \\
\text { lb/hr }\end{array}$ & $\begin{array}{c}\text { Vane Length } \\
\mathbf{f t}\end{array}$ \\
\hline 1 & 35000 & 1 \\
\hline 2 & 45000 & 1 \\
\hline 3 & 35000 & 2 \\
\hline 4 & 45000 & 2 \\
\hline 5 & 35000 & 3.49 \\
\hline 6 & 45000 & 3.49 \\
\hline
\end{tabular}

The six steady state conditions are plotted in Figure 14. Each vane was run at two different mass circulation rates, which corresponded to two different aeration rates. Regression lines are also plotted along with corresponding equations and $\mathrm{R}^{2}$ values. 


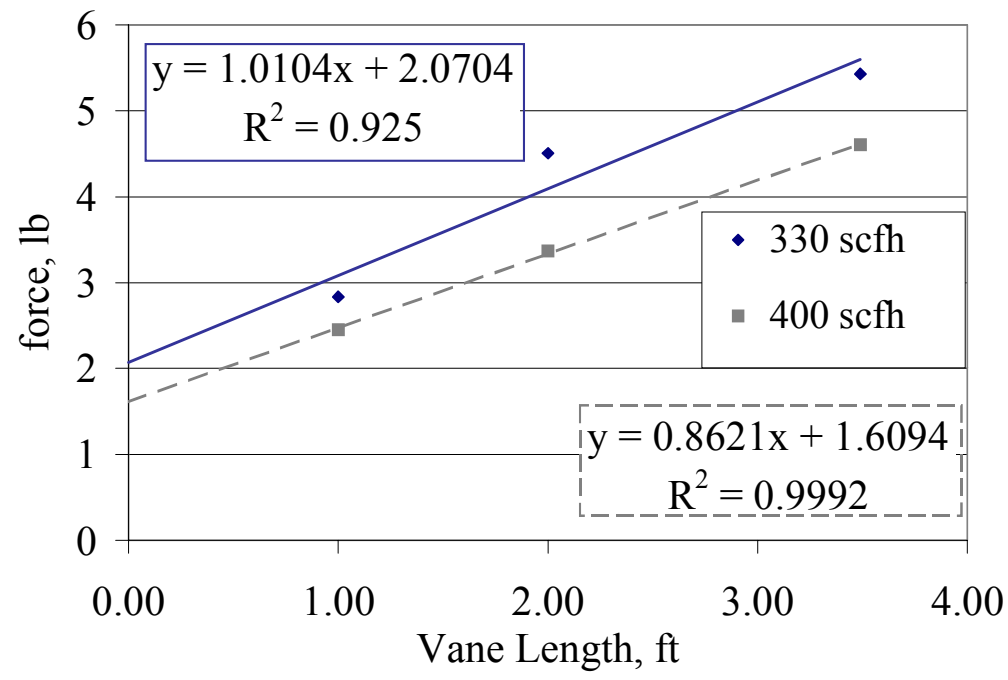

\section{Figure 14: Parasitic Drag Steady Steady State, $230 \mu \mathrm{m}$ Coke}

When examining Figure 14, it is important to note that there was a problem with several of the steady states. During the study, the two vanes not in use were hanged at the wall lower in the standpipe. Under a few conditions, the $3.49 \mathrm{ft}$ vane partially blocked the standpipe outlet to the loopseal. This increased the aeration required to obtain the circulation rates listed in Table 6.

The objective was to determine how much of the force was due to shear and how much was due to drag along the leading edge and cable. If both of the regression lines are extrapolated to the point where they cross zero, the amount of force due to drag will be the intercept. In other words, as the length of the vane or as the area over which shear occurs goes to zero, the force measured goes to $2.07 \mathrm{lb}$ for a move air of $330 \mathrm{scfh}$ and $1.61 \mathrm{lb}$ for a move air of $400 \mathrm{scfh}$.

The above analysis has been applied to the ramp data. There are force measurements for each vane for all move air values from 55 to $405 \mathrm{scfh}$. To determine the y-intercept, which is the point at which the length of the vane goes to zero, a simple linear regression was performed on each increment of move air. Figure 15 gives the total force measured for each vane and the parasitic drag versus aeration rate. Notice that as aeration increases the force measured for all of the vanes decreases. Also, as the vane length increases the overall force measured increases, because the area over which shear occurs increases. The parasitic drag is relatively constant at high aeration rates. 


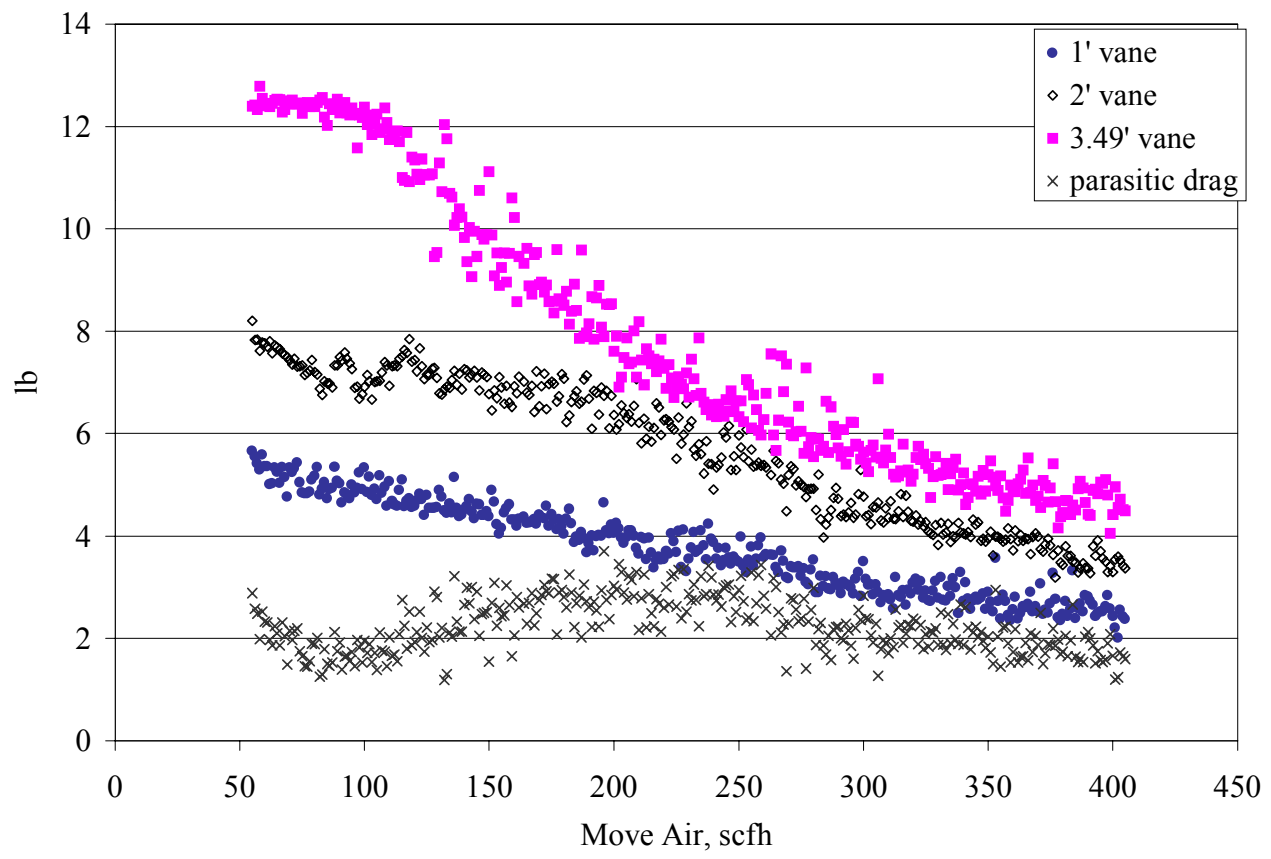

\section{Figure 15: Total Force Measured for Each Vane Length and Parasitic Drag, 230 $\mu \mathrm{m}$ Coke}

Because the magnitude of the force increases with increasing vane length and also because the parasitic drag at a given move air is the same for any vane length, and the percentage of the force measured due to parasitic drag increases as the length of the vane decreases. This means that the ratio of actual shear force to force measured increases with increasing vane length. In Figure 16, the ratio of shear force to total force is plotted as a function of the aeration rate. At high flows this ratio is constant for all vane lengths, and at low flows the ratio decreases as the aeration rate increases. At very low flows, the ratio actually increases as the aeration rate increases. This behavior has been captured with a $4^{\text {th }}$ order polynomial regression. Notice that the ratio is as low as 0.25 for a vane of 1' length, which means that $3 / 4$ of the total force measured is due to parasitic drag. The 2' vane gives much better results with the lowest ratios being roughly one half. There is an improvement in the ratio in going from a 2' to $3.49^{\prime}$ length, but this improvement is small. It is desirable to take the measurement over a small length to decrease the size of the control volume, and stay within the assumption that the shear changes little along the length of the control volume. For these reasons the 2' vane length has been selected and used. The $4^{\text {th }}$ order polynomial regression of the ratio of shear Force/Total force for the 
2' vane for flows lower then $270 \mathrm{scfh}$ is given in Equation (30). The $\mathrm{R}^{2}$ value of the regression is 0.664 . This $\mathrm{R}^{2}$ is low due to the high spread in the data

$\frac{\text { ShearForce }}{\text { TotalForce }}=-6.193 \cdot 10^{-10} F_{m}^{4}+5.311 \cdot 10^{-7} F_{m}^{3}-1.554 \cdot 10^{-4} F_{m}^{2}+1.673 \cdot 10^{-2} F_{m}+0.1646$

For flows higher then $270 \mathrm{scfh}$ a linear regression was used, Equation (31). The $\mathrm{R}^{2}$ value for the linear regression is 0.0012 .

$$
\frac{\text { ShearForce }}{\text { TotalForce }}=-5.06 \cdot 10^{-5} F_{m}+0.526
$$

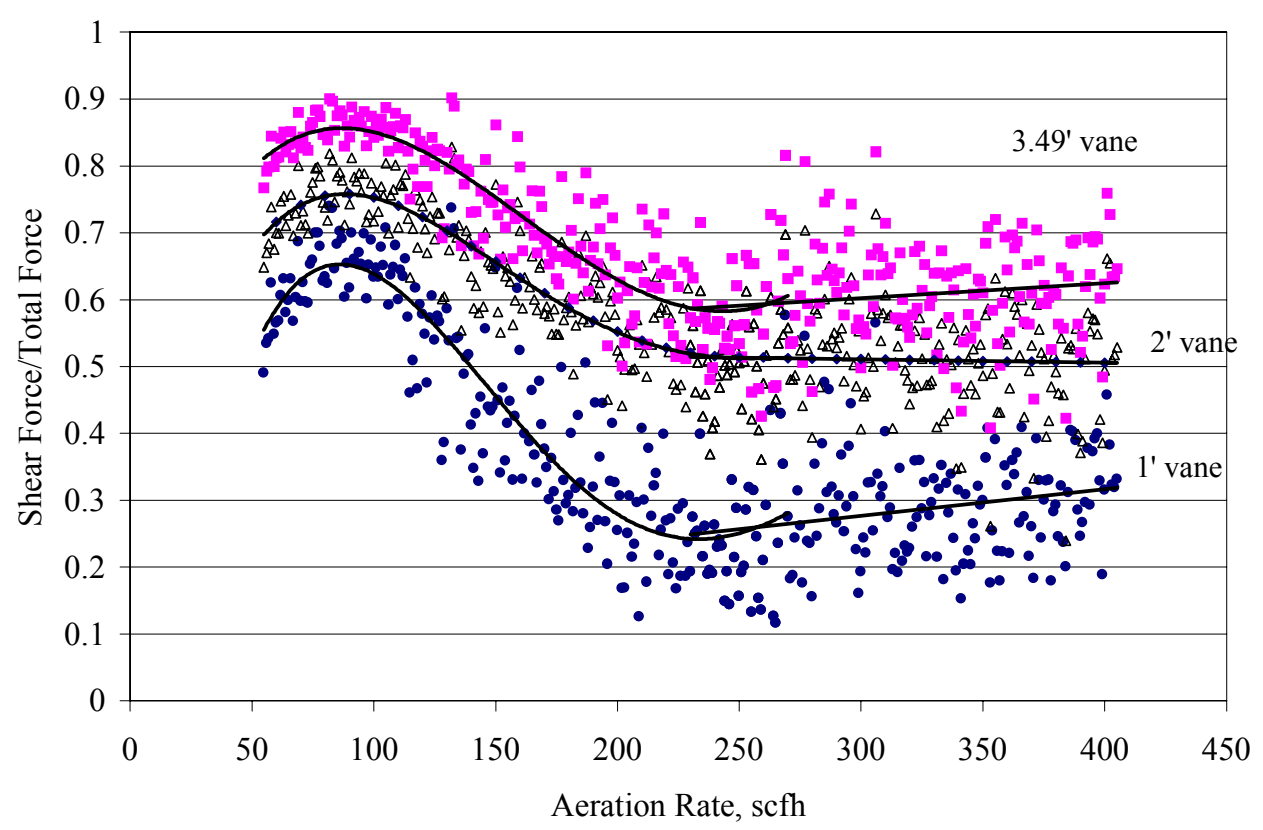

Figure 16: Ratio of Shear Force/Total Force (Parasitic Drag study), $230 \mu \mathrm{m}$ Coke

\subsection{Wall Probe}

\section{5a Wall Probe General Description}

Although the shear vane is easy to use and gives very good qualitative data for trends and differences, there are necessary assumptions when using it. For example, to complete the force balance in a standpipe section, the assumption that the stress measured at the center of the pipe is the same as the stress at the wall is applied. Another assumption is that the amount of force measured by the vane that is due to the drag along the cable and leading edge is very high, about half of the total force measured. 
A new device has been designed to eliminate all of these assumptions. The measurement is taken at the wall. There is no leading edge or cable to create drag. However, there are other issues regarding isolating the probe from particles that will be discussed

A schematic of the wall device is shown in Figure 17. It is based on the deformation of a cantilever beam. The most important aspect of the device is the highly sensitive capacitance displacement sensors. A coupon with a diameter of approximately 5 " is attached to a $5 / 8$ " OD aluminum tube that is attached to a fixed end. Aluminum was chosen for its lower modulus of elasticity. The load or shear applied to the coupon bends the aluminum beam. The capacitance devices measure this displacement. This displacement is linear with the amount of force placed on the coupon, Equation (32) (Higdon, 1985).

$$
d=\frac{-F x^{2}}{9 E I}(3 L-x)
$$

Where $\mathrm{d}$ is the displacement, and $\mathrm{F}$ is the total force on the free end of the tube. The values and description of the constants in equation (32) are listed in Table 7.

Table 7: Description and Values of Constants in Equation Describing Deflection of a Cantilever Beam

\begin{tabular}{|c|c|c|}
\hline Constant & Description & Value \\
\hline $\mathrm{x}$ & Location of desired deflection from the fixed end of the tube & $7 \mathrm{in}$ \\
\hline $\mathrm{E}$ & Modulus of elasticity of aluminum 6061-T6 & $10000 \mathrm{ksi}$ \\
\hline $\mathrm{I}$ & Moment of inertia & $1.366 \cdot 10-7 \mathrm{ft}^{4}$ \\
\hline $\mathrm{L}$ & Length of the cantilever beam (tube) & $8 \mathrm{in}$ \\
\hline $\mathrm{r}_{\mathrm{o}}$ & Outer radius of the tube & $5 / 16 \mathrm{in}$ \\
\hline $\mathrm{r}_{\mathrm{I}}$ & Inner radius of the tube & $0.278 \mathrm{in}$ \\
\hline
\end{tabular}

As mentioned, I is the moment of inertia and is defined by the following Equation (33).

$$
I=\frac{\pi}{4}\left(r_{o}^{4}-r_{i}^{4}\right)
$$




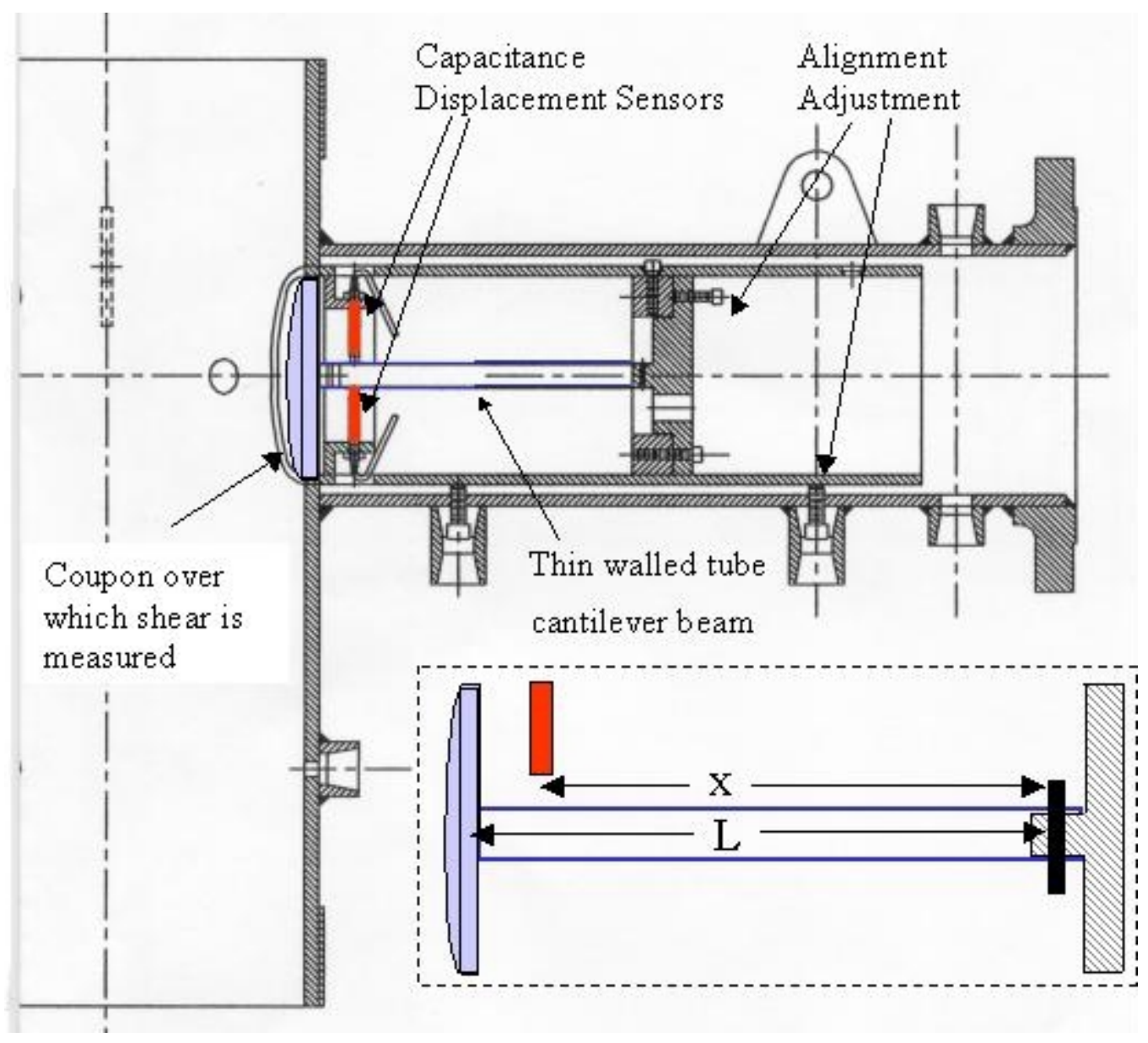

Figure 17: Wall Stress Probe Schematic

\section{5b Wall Probe Calibration}

As described above the capacitance sensors measure the displacement of the tube with the load placed on the coupon. The sensors are highly sensitive and measure distances between 0.01 " and 0.02 ". The factory-supplied calibration has been provided in Figure 18 and Figure 19. There are two probes. One measures change in the axial (updown) direction, and the other measures side-to-side stresses. In the standpipe, mostly axial stresses are expected. 


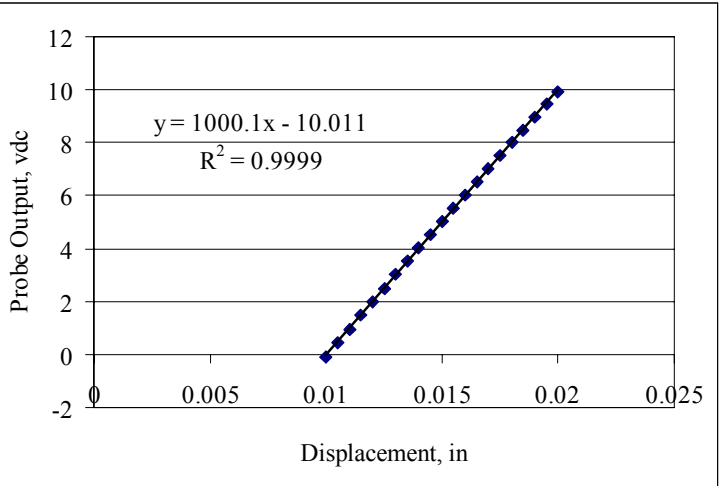

Figure 18: Factory Supplied Calibration of Displacement Probes, Channel 1

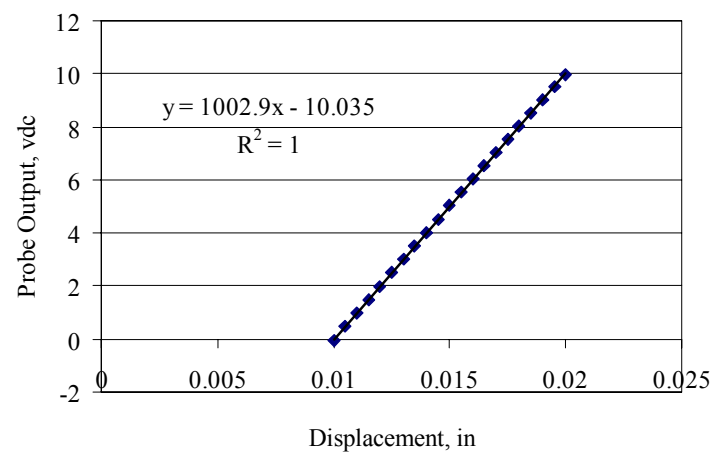

Figure 19: Factory Supplied Calibration of Displacement Probes, Channel 2

Figure 20 shows the calibration for the axial direction probe for stresses pushing downward. It is assumed that stresses pushing up will have the same slope as those pushing down. The probe output is direct current voltage (vdc). Using this calibration, the measured deflection of the beam can be compared with the deflection estimated using Equation (32). See Figure 21.

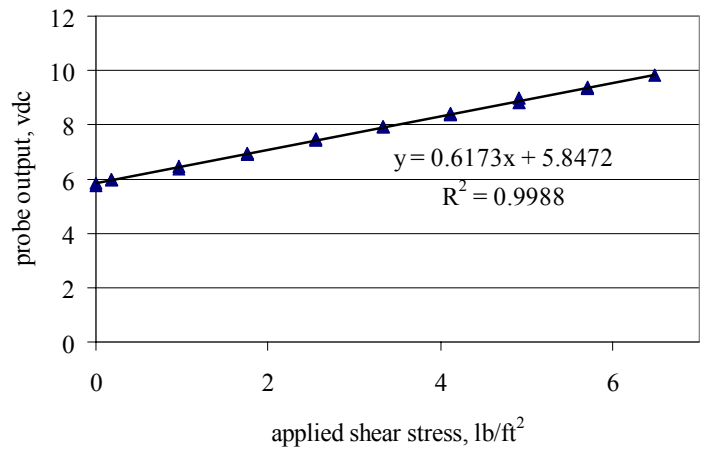

Figure 20: Wall Probe Calibration in the Axial Direction

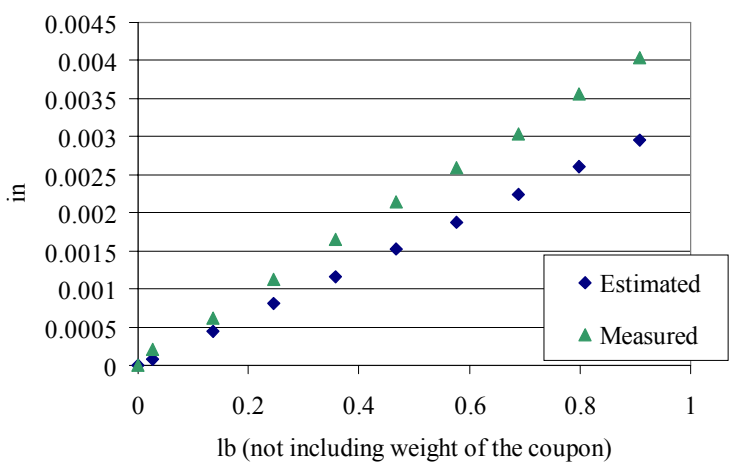

Figure 21: Estimated and Measured Movement of the Tube

The results in Figure 21 suggest that the aluminum tube is bending easier than what the theory would predict. This could be due to error in any of the parameters listed in Table 7. The modulus of elasticity may not be exactly correct. The boundary conditions that define Equation (32) may not be the conditions actually in practice.

Initially the wall probe was used in a stationary bubbling bed. A summary of this work can be found in Chapter 6. During this work, the zero of the probe varied significantly. The level or tilt (not bed height) of the bed was changing due to the nature of the temporary setup. It is believed that the variation in the probe zero was from this 
change in bed level. Figure 22 shows the importance of the level of the probe. Although, the probe zero is dependent on levelness, the slope is essentially constant.

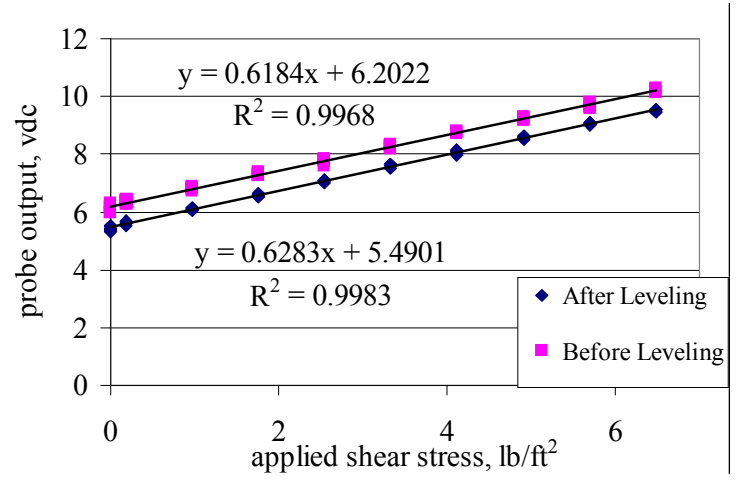

\section{Figure 22: Importance of Probe Level on Calibration}

Since the levelness of the standpipe is unlikely to change, the result from Figure 22 has little impact in the operation of the probe. However, when the probe is located in the standpipe, it is very difficult to calibrate the probe in place, but it is relatively easy to check the zero of the probe. Figure 22 suggests that the slope does not change much. As a result, the zero can be adjusted while keeping a constant slope. An average slope of $6.23 \mathrm{vdc} /\left(\mathrm{lb} / \mathrm{ft}^{2}\right)$ is used.

\section{5c Wall Probe Purge}

As described above the leading edge and drag issues are eliminated, but in their place there are problems with alignment of the probe and particles clogging it. If the probe is misaligned and the edge of the coupon protrudes into the bed, solids pressure in the z-direction, solids impact, and shear will all be measured. In other words the values measured will be inflated. If the probe is not flush with the wall and it is actually depressed in the wall the voidage may increase causing lower measurements. Further, there is $1 / 16$ " clearance between the coupon and the outer assembly of the probe. Initially, it has been proposed that this clearance is left open, and aeration can be used to keep the solids out. This will be tricky since two much aeration may increase the void fraction where the measurement is being taken, and two little aeration may allow particles to clog up the probe.

A three variable factorial study was run to understand the effects of purge aeration, bed aeration ramp direction, and bed aeration level on the solids wall shear 
stress in a stationary bed. Bed aeration refers to the air coming across the distributor plate. This study was conducted in the 10 " bubbling bed with cork bed material. The experimental matrix is listed in Table 8.

Table 8: Test Matrix to Understand Purge Air Effects, Test Bed, $1000 \mu \mathrm{m}$ Cork

\begin{tabular}{|c|c|c|c|c|c|c|c|}
\hline $\begin{array}{l}\text { Run } \\
\text { Order }\end{array}$ & $\begin{array}{c}\text { Ramp } \\
\text { Direction }\end{array}$ & $\begin{array}{c}\text { Bed } \\
\text { Aeration }\end{array}$ & $\begin{array}{c}\text { Purge } \\
\text { Aeration }\end{array}$ & $\begin{array}{c}\text { Shear } \\
\text { Stress by } \\
\text { Wall } \\
\text { Probe } \\
\end{array}$ & $\varepsilon_{\mathrm{s}}$ & $\Delta \mathbf{P}$ & $\begin{array}{c}\text { Bed } \\
\text { Height }\end{array}$ \\
\hline & & scfh & scfh & $\mathbf{l b} / \mathbf{f t}^{2}$ & & $" \mathrm{H}_{2} \mathrm{O}$ & in \\
\hline 15 & up & 100 & 0 & 0.637 & 0.44 & 0.6 & 29.4 \\
\hline 9 & up & 100 & 50 & 0.525 & 0.38 & 0.9 & 30 \\
\hline 6 & up & 400 & 0 & 0.271 & 0.40 & 2.4 & 29.5 \\
\hline 13 & up & 400 & 50 & 0.287 & 0.42 & 2.6 & 30 \\
\hline 2 & down & 100 & 0 & 0.557 & 0.43 & 0.7 & 29 \\
\hline 8 & down & 100 & 50 & 0.51 & 0.37 & 0.9 & 30.3 \\
\hline 12 & down & 400 & 0 & 0.43 & 0.45 & 2.2 & 31.7 \\
\hline 4 & down & 400 & 50 & 0.398 & 0.37 & 2.4 & 32 \\
\hline 7 & up & 100 & 0 & 0.525 & 0.44 & 0.6 & 29.2 \\
\hline 3 & up & 100 & 50 & 0.653 & 0.40 & 0.9 & 29 \\
\hline 1 & up & 400 & 0 & 0.271 & 0.39 & 2.4 & 29.3 \\
\hline 5 & up & 400 & 50 & 0.303 & 0.42 & 2.6 & 30 \\
\hline 14 & down & 100 & 0 & 0.653 & 0.42 & 0.65 & 29.6 \\
\hline 16 & down & 100 & 50 & 0.35 & 0.42 & 2.8 & 32.5 \\
\hline 10 & down & 400 & 0 & 0.446 & 0.38 & 2.3 & 31.5 \\
\hline 11 & down & 400 & 50 & 0.382 & 0.44 & 2.4 & 32.5 \\
\hline
\end{tabular}

These results for shear stress have been summarized in Figures 23 and 24.

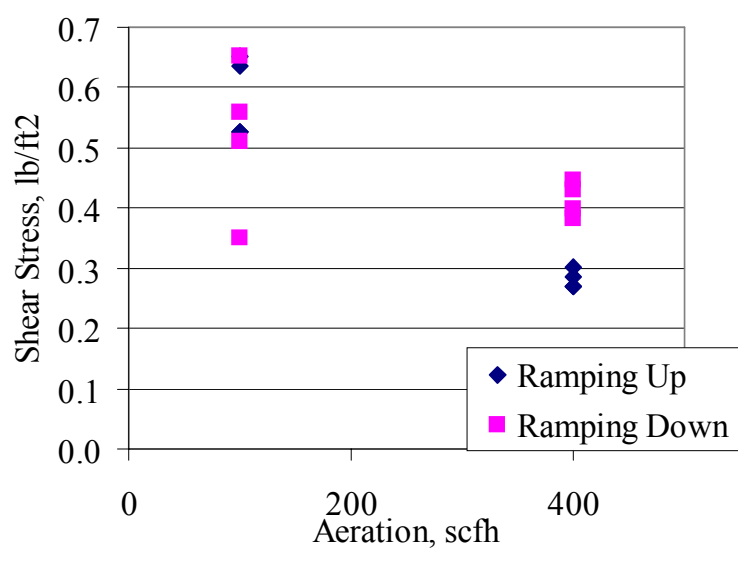

Figure 23: Effects of Purge on Wall Probe Measurements, $1000 \mu \mathrm{m}$ Cork

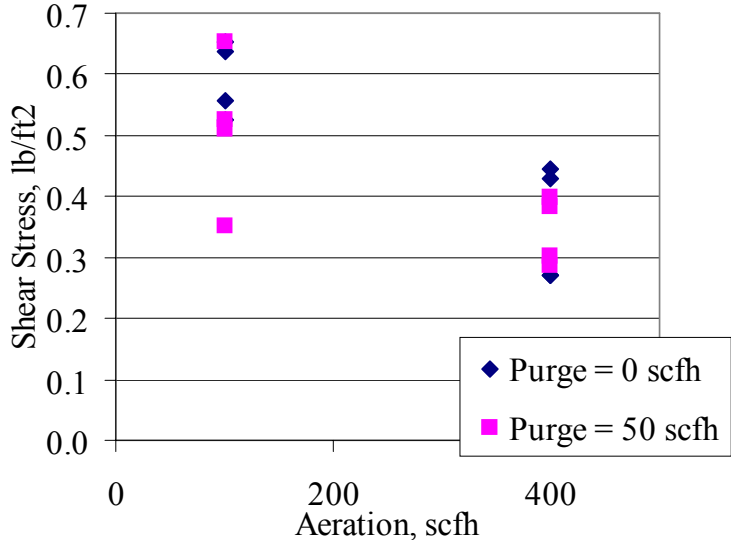

Figure 24: The Effects of Ramp Direction on Wall Shear, $1000 \mu \mathrm{m}$ Cork 
A type I sum of squares analyses was applied to the three independent variables listed in Table 8. Table 9 shows the typical output for a variable. It is specifically for the wall shear stress. Notice that ramp direction, bed aeration, and purge aeration are denoted as RDIR, AERATION, and PAIR respectively.

\section{Table 9: ANOVA of Purge Air Test for Shear Stress, Test Bed, $1000 \mu \mathrm{m}$ Cork}

Tests of Between-Subjects Effects

\begin{tabular}{|c|c|c|c|c|c|c|c|c|}
\hline Source & $\begin{array}{c}\text { Type I } \\
\text { Sum of } \\
\text { Squares }\end{array}$ & df & $\begin{array}{l}\text { Mean } \\
\text { Square }\end{array}$ & $\mathrm{F}$ & Sig. & $\begin{array}{c}\text { Eta } \\
\text { Squared } \\
\end{array}$ & $\begin{array}{l}\text { Noncent. } \\
\text { Parameter }\end{array}$ & $\begin{array}{c}\text { Observec } \\
\text { Power }^{\mathrm{a}}\end{array}$ \\
\hline $\begin{array}{l}\text { Corrected } \\
\text { Model }\end{array}$ & $.241^{\mathrm{b}}$ & 7 & 3.449E-02 & 8.554 & .004 & .882 & 59.879 & .980 \\
\hline Intercept & 3.238 & 1 & 3.238 & 803.125 & .000 & .990 & 803.125 & 1.000 \\
\hline RDIR & 4.032E-03 & 1 & 4.032E-03 & 1.000 & .347 & .111 & 1.000 & .143 \\
\hline AERATION & .164 & 1 & .164 & 40.781 & .000 & .836 & 40.781 & 1.000 \\
\hline PAIR & $9.120 \mathrm{E}-03$ & 1 & $9.120 \mathrm{E}-03$ & 2.262 & .171 & .220 & 2.262 & .264 \\
\hline $\begin{array}{l}\text { RDIR * } \\
\text { AERATION }\end{array}$ & 3.940E-02 & 1 & 3.940E-02 & 9.772 & .014 & .550 & 9.772 & .781 \\
\hline $\begin{array}{l}\text { RDIR * } \\
\text { PAIR }\end{array}$ & 1.626E-02 & 1 & 1.626E-02 & 4.032 & .080 & .335 & 4.032 & .424 \\
\hline $\begin{array}{l}\text { AERATION } \\
{ }^{*} \text { PAIR }\end{array}$ & 5.112E-03 & 1 & $5.112 \mathrm{E}-03$ & 1.268 & .293 & .137 & 1.268 & 169 \\
\hline RDIR * & & & & & & & & \\
\hline $\begin{array}{l}\text { AERATION } \\
{ }^{*} \text { PAIR }\end{array}$ & 3.080E-03 & 1 & & .764 & .408 & .087 & .764 & .121 \\
\hline Error & 3.226E-02 & 8 & 4.032E-03 & & & & & \\
\hline Total & 3.512 & 16 & & & & & & \\
\hline $\begin{array}{l}\text { Corrected } \\
\text { Total }\end{array}$ & .274 & 15 & & & & & & \\
\hline
\end{tabular}

The ANOVA table in Table 9 gives insight into which variables have a significant impact and the strength of the model. Any variable that has significance less then 0.05 made a significant impact on the solids wall shear stress, or that there is a $95 \%$ confidence that variable had a significant impact. From Table 9, aeration and an interaction between aeration and ramp direction are significant. Further, the interaction between ramp direction and purge air is very close to being significant. Eta-squared is the proportion of total variability of the dependent variable that is described by the variation in the independent variable. It is the ratio between groups sum of square and the total sum of square (SPSS Inc., 1997). Bed aeration had the largest eta-squared, which means changes in it resulted in the largest changes of shear stress. The R-squared measures the proportion of variability of the dependent variable that is explained by the relationship between the independent variable and dependent variables (Schmidt, 1998). 
The model explains $78 \%$ of the variability of shear stress and $22 \%$ of the variation is noise or unexplained variation.

As a result of this test, there is not enough evidence to show that purge air affects the wall shear stress. However, because the significance level of the interaction between ramp direction and purge air is less then 0.1 and due to the lower R-squared value it is difficult to throw this effect out. Staged aeration on the order of $50 \mathrm{scfh}$ is often used to produce desired changes in the standpipe. Because of the two previous concerns and also due to operational concerns, another alternative has been investigated. Nylon mesh has been stretched across the front of the probe. Another coupon sandwiches this mesh between it and the original carbon steel coupon. This coupon is the surface that comes in contact with the particles. Concerns with the mesh is that it provides a rough area over which shear can occur. Further, it does not allow the beam to rebound as easily, and lastly, it is fragile and susceptible to fraying.

\section{5d Wall Probe Repeatability}

A repeatability study was run to understand the measurement error associated with using the wall probe. Eight weights, which correspond to eight different shear stresses, were selected over the range of shear stress expected for coke breeze. First, the weights were added to the probe in an increasing manner, and then they were removed in a decreasing manner. This was done twice, and the intent was to determine if there was any hysteresis effect of the probe. See Figure 25 for the first set of increasing and decreasing data.

The actual probe output versus applied shear stress in Figure 25 does not show much hysteresis. However, the difference between increasing stress and decreasing stress was plotted on the right y-axis. This difference shows that the hysteresis increases at lower shear stresses. In other words there is more error associated with the hysteresis at lower shear stresses.

The next part of the repeatability test was to randomly apply the eight shear stresses. This was repeated three times. The sequence of this test is shown in Table 10. Figure 26 shows all of the repeatability data taken as well as the hysteresis data. 


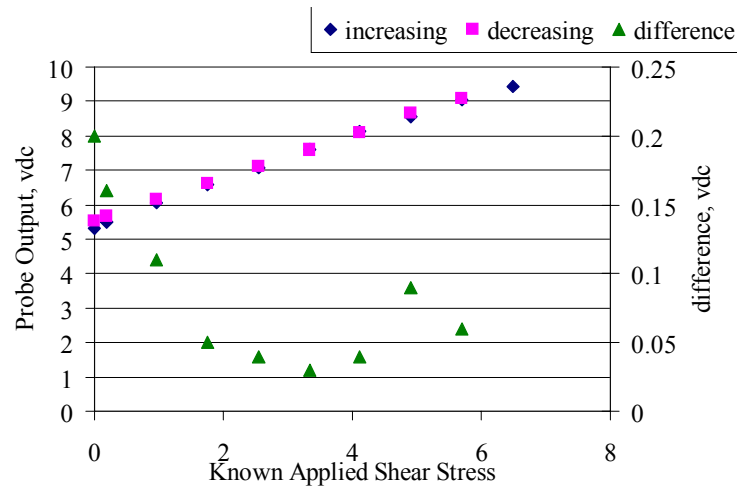

Figure 25: Hysteresis Effect of Wall Probe

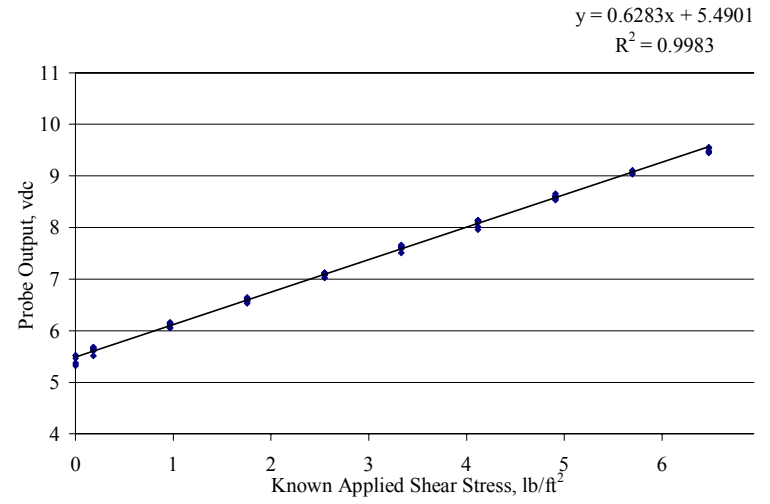

Figure 26: Wall Probe Repeatability Study

Table 10: Test Sequence of Repeatability Test

\begin{tabular}{|c|c|c|}
\hline Test 1 sequence (lb/ft & Test 2 & Test 3 \\
\hline 0 & 0 & 0 \\
\hline 0.182 & 0.182 & 0.182 \\
\hline 4.911 & 4.118 & 2.549 \\
\hline 6.482 & 5.698 & 6.482 \\
\hline 3.334 & 1.756 & 4.911 \\
\hline 0.967 & 4.911 & 5.698 \\
\hline 2.549 & 6.482 & 3.334 \\
\hline 5.698 & 3.334 & 1.756 \\
\hline 4.118 & 2.549 & 4.118 \\
\hline 1.756 & 0.967 & 0.967 \\
\hline
\end{tabular}

Using the regression shown in Figue 26, the amount of error in the measurement can be seen from Figure 27 for coke breeze range and Figure 28 for cork range.

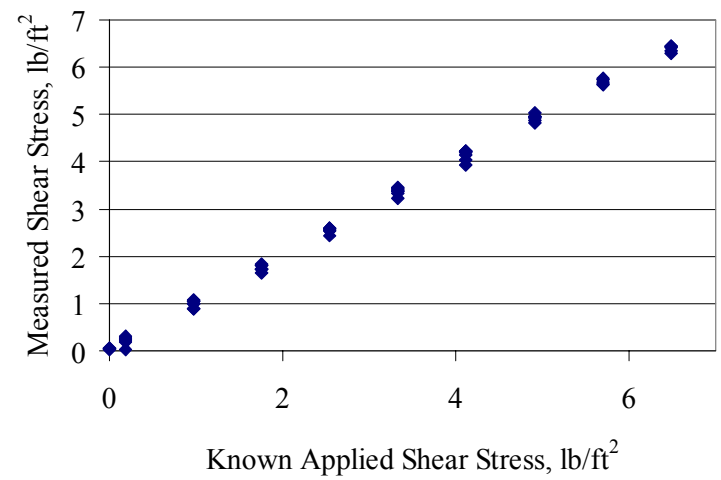

Figure 27: Wall Probe Measurement Error for Coke Breeze Range

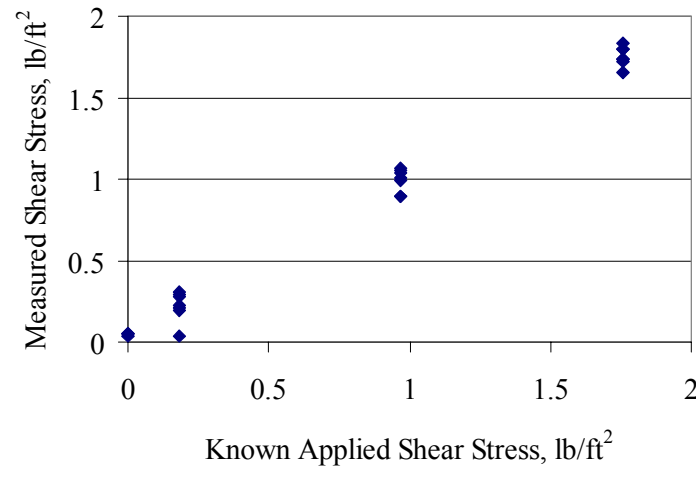

Figure 28: Wall Probe Measurement Error for Cork Range 
Based on the variability shown in Figure 27, the error associated with the wall probe is \pm 0.18 for a \pm 2 s limits (Doebelin, 1983). This corresponds to a $4 \%$ of scale for coke breeze and a $14 \%$ of scale for cork. The percent of scale for cork is poor. However, keep in mind that the repeatability study was performed with coke breeze in mind. This included ranges that would never be seen with cork. Therefore, including higher ranges in the repeatability study may have inflated the amount of error.

Comparing the error for wall probe in this study to the error reported for the shear vane in Section 3.4b. There is more error in the wall probe measurement than the shear vane measurement. However, in comparing the error it is important to note that the studies were performed differently. The shear vane included simply one ramp up and down in weight. The wall probe included two ramps up and down and three randomized repeatability test. The randomized test is designed to give an unbiased measurement of error. Also, keep in mind that the shear vane measures shear stresses over a two-foot length in the center of the pipe. The wall probe measures shear stress at the wall over an approximately five-inch diameter coupon.

To understand where the error is coming from, the above analysis has been applied to the wall probe when there was no nylon covering the front. The amount of error seen for both the coke breeze range and the cork range is shown below in Figures 29 and 30 , respectively.

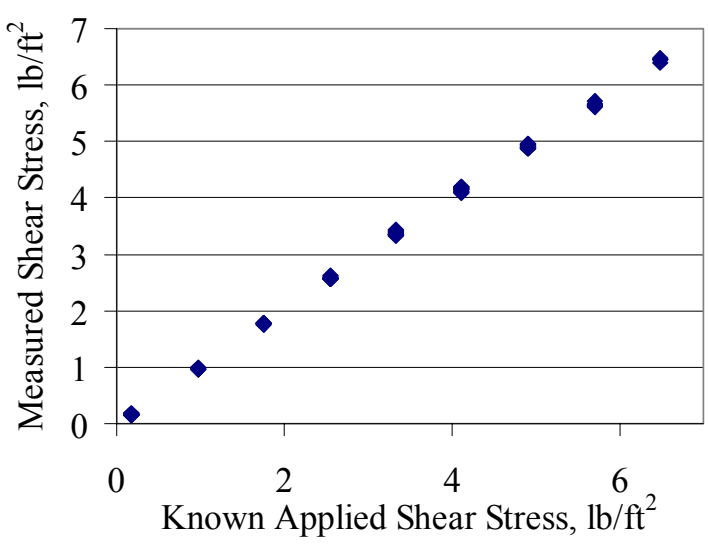

Figure 29: Wall Probe Measurement Error for Coke Breeze Range No Nylon

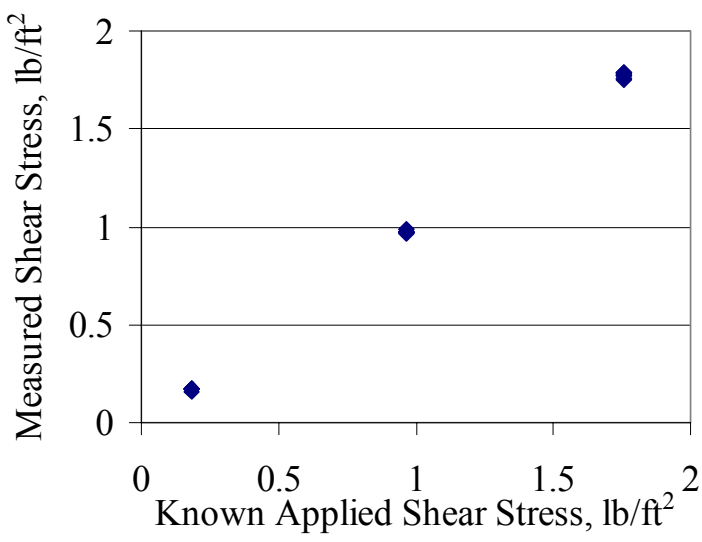

Figure 30: Wall Probe Measurement Error for Cork Range No Nylon

Based on the variability shown in Figures 29 and 30, the error associated with the wall probe without the nylon covering is \pm 0.075 for a \pm 2 s limits (Doebelin, 1983). This 
corresponds to a $2 \%$ of scale for coke breeze and a $5 \%$ of scale for cork. Since the two studies are carried out identically, this shows that the nylon mesh contributes much to the error. Using the nylon mesh as opposed to using purge air is a trade off. Problems associated with the mesh include the noticeably increase in error and the possibility of over predicting the shear due to the shear of the nylon. A problem associated with the purge is the concern of changing the void fraction where the measurement is being taken. Further, there are operational issues such as maintaining aeration on the wall probe at all times, even when the unit is not in operation.

\subsection{Capacitance Solids Volume Fraction Probe}

\section{6a Capacitance Solids Volume Fraction Probe General Description}

A capacitance probe, developed by Michel Louge, Cornell University (1992), has been used to measure solids volume fraction. A schematic of the probe has been provided in Figure 31. The probe is mounted flush with the inside of the wall. The probe itself is electrically isolated from the rest of the spool piece and standpipe. An electric field develops between the sensor in the center of the probe and the ground, which is the outer ring of the probe. The probe gives a voltage output $(\mathrm{V})$, which is proportional to the capacitance of this electric field. The capacitance is a function of the geometry of the field and the properties of the material within it. Since the geometry of the field is not changing, the probe will measure changes in the properties of the material. The property of interest is the solids volume fraction, which is related to the effective dielectric constant of the suspension in the field, $K_{\text {eff. }}$ The voltage of the wall section with no solids, just gas, is of importance and is denoted as $\mathrm{V}_{0}$. The ratio of $\mathrm{V}_{0} / \mathrm{V}$, where $\mathrm{V}$ is the voltage output due to the suspension, is equal to the effective dielectric constant of the

suspension, $\mathrm{K}_{\mathrm{eff}}$. Louge (1992) suggest using a model by (B $\overline{\mathrm{ttcher}}$ 1945) to relate the effective dielectric constant to the solids volume fraction, Equation (34).

$$
\frac{K_{e f f}-K_{h}}{3 K_{e f f}}=\varepsilon_{s} \frac{K_{p}-K_{h}}{K_{p}+2 K_{e f f}}
$$


$\mathrm{K}_{\mathrm{h}}$ is the same as $\mathrm{K}_{\text {eff }}$ when the vessel is filled only with gas. Louge (1992) suggests the Equation (35) to estimate the dielectric constant of the bed material with no voids. This equation can be found by solving Equation (34) for $\mathrm{K}_{\mathrm{p}}$.

$$
K_{p}^{e s t}=K_{e f f} \frac{3 \varepsilon_{c} K_{h}+2 K_{e f f}-2 K_{h}}{K_{e f f}\left(3 \varepsilon_{c}-1\right)+K_{h}}
$$

In this equation $\mathrm{K}_{\mathrm{eff}}$ is the dielectric constant of the packed material of known solids fraction, $\varepsilon_{\mathrm{c}}$. Note that this method of solids volume fraction cannot be applied to conductive bed materials. As a result, measurements cannot be made of coke breeze.

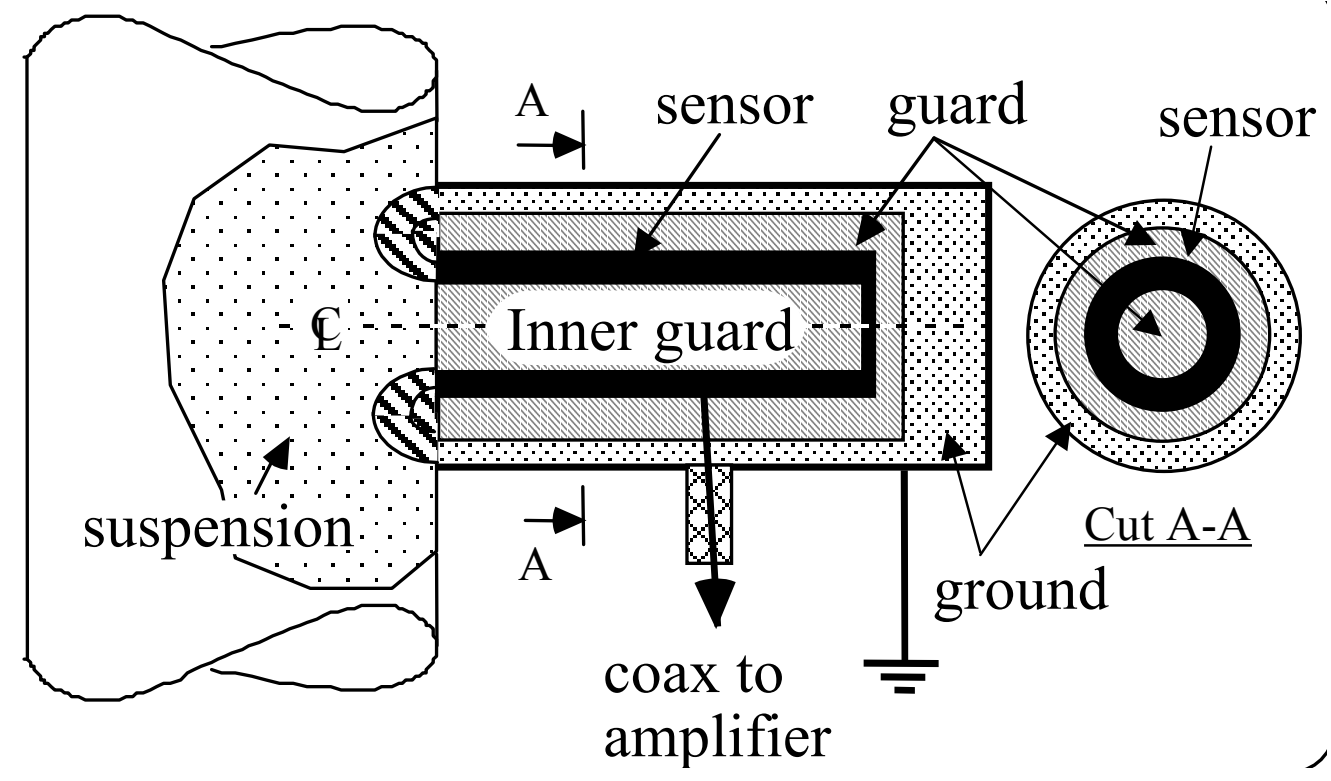

Figure 31: Solids Volume Fraction Probe (Louge, 1992)

The volume over which the solids volume fraction is measured is worth noting. According to Michel Louge (1992), the depth of the measurement is about $16 \%$ of the diameter of the probe. The probe diameter is $3 / 8$ ". Therefore, the measurement reaches as far as 0.06 " into the bed. This corresponds to 1.5 cork particles that are 1000 micron in diameter.

\section{6b Capacitance Solids Volume Fraction Probe Calibration}

The solids volume fraction probe was calibrated in a four-inch I.D. bubbling bed. To calibrate the probe it is necessary to estimate the dielectric constant of cork using Equation (35), since the dielectric constant of cork could not be found in the literature. The closest material to cork listed was balsa wood at 1.4 (Von Hippel, 1954). To use 
Equation (35) the solids volume fraction must be known for at least one condition. The bulk density is easily measured using the volume of the bubbling bed and the total weight of the bed material, Equation (36). If the density of the cork particle is known, the solids volume fraction can be found. See Equation (36)

$$
\rho_{b}=\frac{W_{\text {bed }}}{V_{\text {bed }}}=\varepsilon_{s} \rho_{s}
$$

$\rho_{\mathrm{b}}$ and $\rho_{\mathrm{s}}$ are the bulk and particle densities respectively. $V_{\mathrm{bed}}$ is the volume of the bed material measured by the cross sectional area of four-inch pipe and the height of the bed. $\mathrm{W}_{\text {bed }}$ is the total weight of the bed added, and $\varepsilon_{\mathrm{s}}$ is the solids volume fraction.

A search of the literature turned up a specific gravity range for cork of 0.12 to 0.2 and it was suggested that $89 \%$ of cork tissues consists of gaseous matter (Granorte, 2001). To narrow this range, an attempt to measure the particle density of cork was made. A description of these measurements is in Section 3.6c. The specific gravity for the cork used in this study was approximately 0.214 , which is slightly heavier then what was found in the literature. This corresponds to $13.36 \mathrm{lb} / \mathrm{ft}^{2}$.

The calibration sequence included taking readings at a range of packings of cork from no cork to compressed, packed cork. First, to determine the $\mathrm{V}_{0}$ discussed in Section 3.6a, a reading was taken with no cork introduced to the bed. Next a known weight of cork material was added to the bed. Readings were taken at this packing state. Aeration was introduced to the bed, and readings were taken for a range of aeration. Further, the bed was compressed to get high solids volume fraction readings. The bed height readings for all of the above tests were used to estimate bulk densities and solids volume fraction with the assumption that the bed expands homogeneously. Unfortunately, visually the bed was not expanding homogeneously. Bubbles tended to run up the side of the bed opposite of the probe. Constants used in this study are listed in Table 11.

Table 11: Solids Volume Fraction Probe Calibration Constants

\begin{tabular}{|c|c|}
\hline Constant Description & Constant Value \\
\hline ID (inches) & 4 \\
\hline Bed Material Weight $(\mathrm{lb})$ & 0.45 \\
\hline Particle Density $\left(\mathrm{lb} / \mathrm{ft}^{3}\right)$ & 13.36 \\
\hline $\mathrm{K}_{\mathrm{h}}$ & 1 \\
\hline $\mathrm{K}_{\mathrm{p}}$, balsa wood & 1.4 \\
\hline $\mathrm{V}_{0}$ & 7.02 \\
\hline
\end{tabular}


The results from the calibration test are listed in Table 12.

Table 12: Solids Volume Fraction Probe Calibration Results

\begin{tabular}{|c|c|c|c|c|c|c|c|c|c|c|}
\hline $\begin{array}{l}\text { Test } \\
\text { Num }\end{array}$ & $\begin{array}{c}\text { Bed } \\
\text { Height } \\
\text { in }\end{array}$ & $\begin{array}{c}\text { Scf } \\
h\end{array}$ & $\begin{array}{c}\text { Probe } \\
\text { Output } \\
\text { vdc }\end{array}$ & $" \mathrm{H}_{2} \mathrm{O}$ & $\mathbf{l b} / \mathbf{f t}^{3}$ & $\begin{array}{c}\varepsilon_{\mathrm{s}} \\
\text { by } \\
\rho_{\mathrm{b}}\end{array}$ & $\mathbf{K}_{\mathrm{eff}}$ & $\mathbf{K}_{\mathbf{p}}$ & $\begin{array}{c}\varepsilon_{\mathrm{s}} \\
\text { by } \\
\text { probe } \\
\text { output }\end{array}$ & $\begin{array}{c}\boldsymbol{\varepsilon}_{\mathrm{s}} \\
\text { by } \\
\text { Balsa } \\
\mathbf{K}_{\mathbf{p}}\end{array}$ \\
\hline 1 & 11.3 & 0 & 3.59 & & 5.47 & 0.42 & 1.96 & 4.15 & 0.36 & 2.16 \\
\hline 2 & 10. & 0 & 2.82 & & 6.07 & 0.46 & 2.49 & 5.52 & 0.49 & 3.18 \\
\hline 3 & 11.7 & 0 & 3.19 & & 5.29 & 0.40 & 2.20 & 5.43 & 0.42 & 2.64 \\
\hline 4 & 11.7 & 10 & 3.26 & & 5.29 & 0.40 & 2.15 & 5.21 & 0.41 & 2.55 \\
\hline 5 & 11.7 & 20 & 3.27 & 0.2 & 5.29 & 0.40 & 2.15 & 5.18 & 0.41 & 2.54 \\
\hline 6 & 11.7 & 30 & 3.27 & 0.35 & 5.29 & 0.40 & 2.15 & 5.18 & 0.41 & 2.54 \\
\hline 7 & 11.7 & 40 & 3.27 & 0.5 & 5.29 & 0.40 & 2.15 & 5.18 & 0.41 & 2.54 \\
\hline 8 & 11.7 & 50 & 3.275 & 0.6 & 5.29 & 0.40 & 2.14 & 5.16 & 0.41 & 2.53 \\
\hline 9 & 11.9 & $>50$ & 3.308 & 0.9 & 5.21 & 0.40 & 2.12 & 5.18 & 0.40 & 2.49 \\
\hline 10 & 12.1 & $>50$ & 3.32 & 0.95 & 5.10 & 0.39 & 2.11 & 5.30 & 0.40 & 2.47 \\
\hline
\end{tabular}

Variables that were recorded during the study were bed height, aeration, probe output and pressure drop across the bed, which are the first four columns in Table 12. The bulk density was calculated using the bed height, diameter of the bed and total weight of material in the bed using Equation (36). The solids volume fraction (by $\rho_{\mathrm{b}}$ ) was calculated using $\rho_{\mathrm{b}}$, the density of cork, and Equation (36). $\mathrm{K}_{\mathrm{eff}}$ is simply the voltage output with no bed material, $\mathrm{V}_{0}$, divided by the voltage output of the suspension under test conditions. $\mathrm{K}_{\mathrm{p}}$ is calculated using Equation (35). The solids volume fraction by probe output was found by using the average $\mathrm{K}_{\mathrm{p}}$ found in this study, 5.148, with the $\mathrm{K}_{\mathrm{eff}}$ in equation (34). Solids volume fraction by Balsa $K_{p}$ was found by using the balsa wood $\mathrm{K}_{\mathrm{p}}$ from the literature in equation (34). The $\mathrm{K}_{\mathrm{p}}$ using this calibration technique was considerably higher than the $\mathrm{K}_{\mathrm{p}}$ listed for balsa wood in the literature. This may be due to the adjustment of the gain of the probe. The gain of the probe was turned up to give a larger voltage change between the absence of bed material and packed cork. The differences between the $\mathrm{K}_{\mathrm{p}}$ estimated for cork and the $\mathrm{K}_{\mathrm{p}}$ listed for balsa wood would explain why the balsa $\mathrm{K}_{\mathrm{p}}$ gives solids volume fraction values that are obviously incorrect. If the solids volume fraction measurements using the bulk density are compared with the solids volume fraction measurements using the probe, Figure 32 results. 


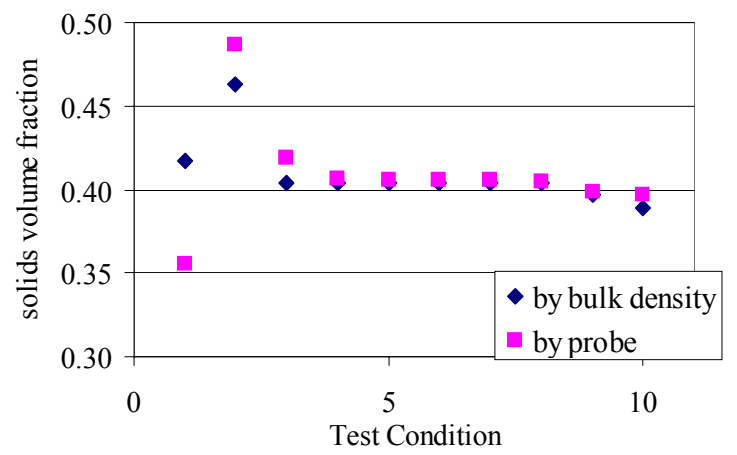

\section{Figure 32: Calibration Results of the Solids Volume Fraction Probe}

Differences between measurements made using the probe and measurements made using the bulk density may be due to the assumption made when using the bulk density. When the bulk density is used to measure solids volume fraction, it is assumed that the bed expands homogeneously. As already mentioned, this may not be the case.

\section{6c Cork Particle Density Measurement}

It is necessary to measure the particle density of cork in order to perform the calibration sequence of the solids volume fraction probe in Section 3.6b. A simple water displacement technique is used. However, special techniques are employed because cork generally floats on top of the water. It is assumed that any water absorbed by the cork and any air bubbles trapped in the cork during this study are negligible. A weighed graduated cylinder is partially filled with cork. The weight of the cork is noted. Water is then poured into the cylinder that contains the cork, and the weight of the water is noted. The volume of the water is found by dividing this weight by the density of water. A water density of $1 \mathrm{gr} / \mathrm{cc}$ was used. The cork is then submerged into the cylinder by pushing a screen that is attached to a rod down on it. The total volume of the mixture is measured. The volume of the screen is ignored. The volume of the cork is found by subtracting the volume of the water from the total volume of the mixture. The density of the cork is the weight of the cork divided by the calculated volume of the cork. A summary of our measurements is in Table 13. 
Table 13: Cork Particle Density Measurements

\begin{tabular}{|c|c|c|c|c|c|c|}
\hline $\begin{array}{c}\text { Person Making } \\
\text { Measurement }\end{array}$ & Material & $\begin{array}{c}\text { Solids } \\
\text { Weight } \\
\mathbf{g r}\end{array}$ & $\begin{array}{c}\text { Water } \\
\text { Weight } \\
\mathbf{g r}\end{array}$ & $\begin{array}{c}\text { Total } \\
\text { Volume } \\
\mathbf{c c}\end{array}$ & $\begin{array}{c}\text { Particle } \\
\text { Density } \\
\mathbf{g r} / \mathbf{c c}\end{array}$ & $\begin{array}{c}\text { Particle } \\
\mathbf{\text { density }} \\
\mathbf{l b}_{\mathbf{f t}} \mathbf{f t}^{\mathbf{3}}\end{array}$ \\
\hline CL & clean cork & 29.92 & 462.19 & 605 & 0.210 & 13.079 \\
\hline AS & clean cork & 15.6 & 345.43 & 411 & 0.238 & 14.852 \\
\hline AS & $\begin{array}{c}\text { coke contam. } \\
\text { cork }\end{array}$ & 28.72 & 260.97 & 401 & 0.205 & 12.804 \\
\hline AS & $\begin{array}{c}\text { coke contam. } \\
\text { cork }\end{array}$ & 27.71 & 310.49 & 445 & 0.206 & 12.861 \\
\hline AS & clean cork & 29.54 & 328.27 & 420 & 0.322 & 20.104 \\
\hline
\end{tabular}

\subsection{Experimental Methods}

\section{7a Steady State versus Transient Data Sampling}

Throughout this work both steady state and transient data have been utilized. Understanding the difference between each type of data is necessary to understand the limitations in each method.

To record steady state data, the desired process condition was obtained. This condition was held until all variables were relatively constant over time. Once all variables were constant, the condition is held for another five minutes, over which time a five-minute running average of all pertinent variables was recorded. Steady state data was taken when noteworthy conditions were obtained. Further, steady state data was used in the statistical studies, which will be described in Chapter 5.

Transient data sampling was recorded at all times. Transient data sampling is how variables change with time. All process variables were continuously sampled every second except for solids circulation, which was averaged over two seconds.

\section{7b Steady State versus Transient Aeration Ramps}

Aeration ramps have been used to sweep through a large range of operating conditions in a short period of time. This technique allowed the comparison of the forces in the momentum balance across flow regimes.

Two different methods, which have been discussed in Section 3.7a, were used to perform aeration ramps. An example of each is plotted in Figures 33 and 34 for transient 
and steady state ramps, respectively. Note that the $\mathrm{x}$-axis is the time in seconds since an arbitrary start time.

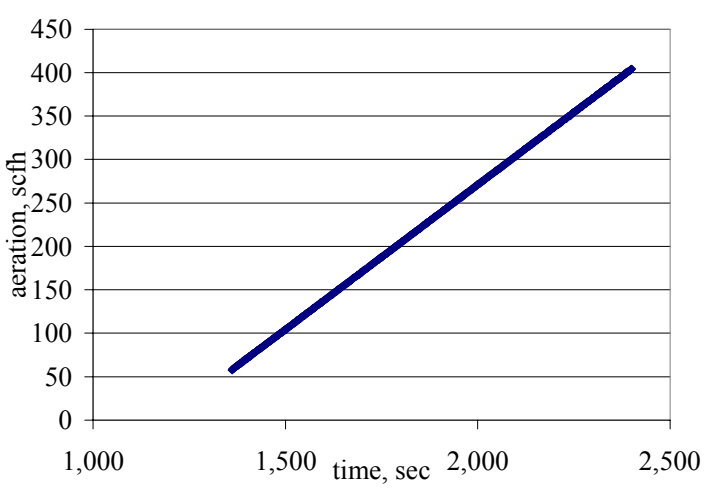

Figure 33: Transient Aeration Ramp

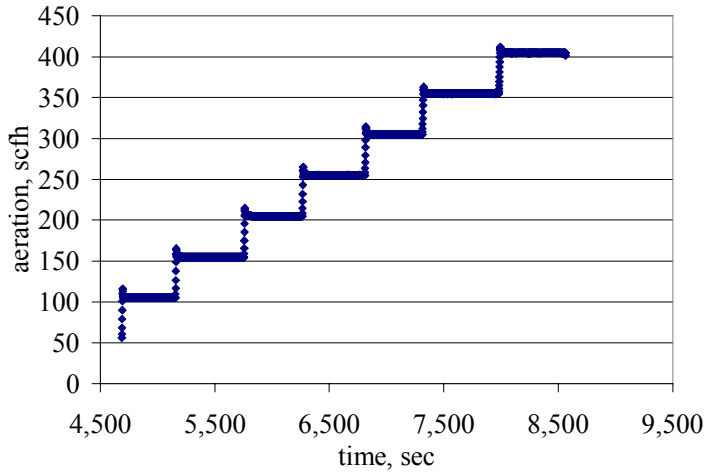

Figure 34: Steady State Aeration Ramp

In the transient ramp the aeration at the bottom of the standpipe was ramped from 50 to $400 \mathrm{scfh}$ at a rate of $20 \mathrm{scfh} / \mathrm{min}$. The steady state ramp was performed by first reaching an aeration of $100 \mathrm{scfh}$ then pausing for five minutes. Next, an aeration of 200 scfh was achieved and again the system was held at this aeration for $5 \mathrm{~min}$. This sequence was continued until $400 \mathrm{scfh}$ was achieved.

To compare results of a transient aeration ramp to results of steady state aeration ramp, both were performed. In general, the response variables in this study were the solids circulation rate, gas phase pressure drop, and solids-wall shear stress. A comparison of transient ramp to aeration ramp values of each of these response variables is plotted in Figures 35-37. The error bars are based on two standard deviations of the 300 data points taken over five minutes for the steady state aeration ramp. 


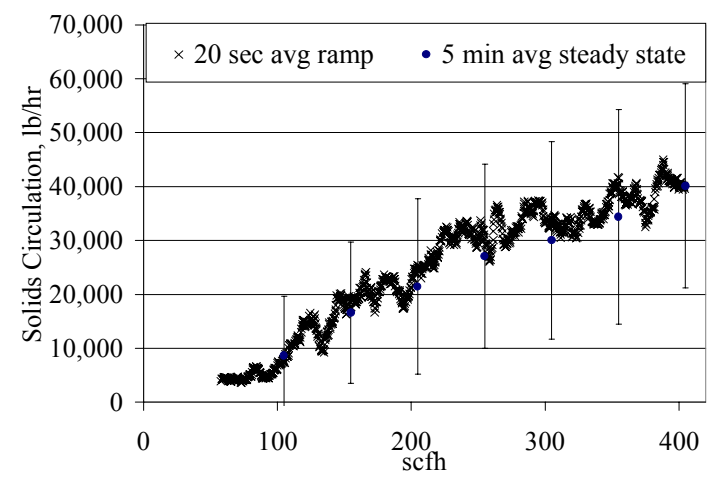

Figure 35: Comparison of Steady State and Transient Ramps for Solids Circulation, $230 \mu \mathrm{m}$ Coke

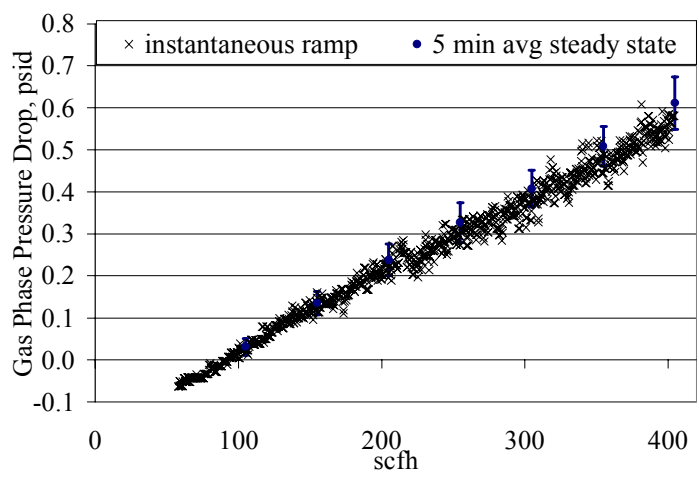

Figure 36: Comparison of Steady State and Transient Ramps for Gas Phase Pressure Drop, $230 \mu \mathrm{m}$ Coke

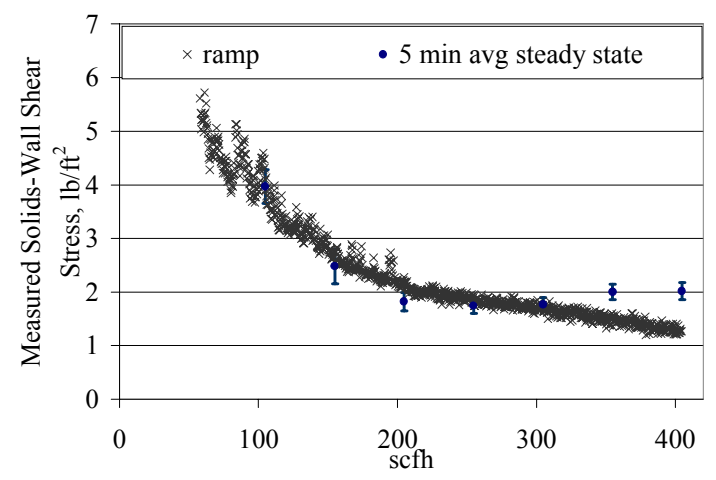

Figure 37: Comparison of Steady State and Transient Ramps for Solids-Wall Shear Stress, $230 \mu \mathrm{m}$ Coke

In general, the steady state ramp agreed well with the transient ramp. In Figure 35, the steady state points for solids circulation run slightly lower then the transient values, but the transient values fall within the error bars. The transient values also fall within the error bars for gas pressure drop. Although most of the transient values fall within the error bars for shear stress, at higher flow rates the transient values are slightly lower. Because the error bars are based on one steady state ramp, they may be too small for shear stress. If this analysis was repeated multiple times for the steady states and obtaining the steady state values from multiple directions, the error bars for both methods would probably cross, even for shear stress at higher flows. As a result, transient ramps have been used in this study for convenience. However, steady state ramps have also been used when possible. 


\subsection{Internal Angle of Friction and Angle of Wall Friction for the Bed Material}

A simple visual technique was used to determine the internal angle of friction of the bed materials (Zenz, 1960). This technique is not necessarily accepted by today's standards that are typically using the Jenike shear cell, which is more accurate (Schulze, 2000). This technique was chosen for its ease of implementation. Measurements for coke breeze have been obtained using the Jenike shear cell.

The procedure involves filling a clear tube with a flat bottom with the test material. The flat bottom must have a concentric hole, which is plugged during the filling process. Once the tube is filled, the top is leveled off, and the plug is removed. The top of the material is carefully watched as the material discharges. The top should move as a plug or undisturbed, until a certain height where a dimple forms. The height at which the dimple forms is the measurement of interest. This set-up is illustrated in Figure 38.
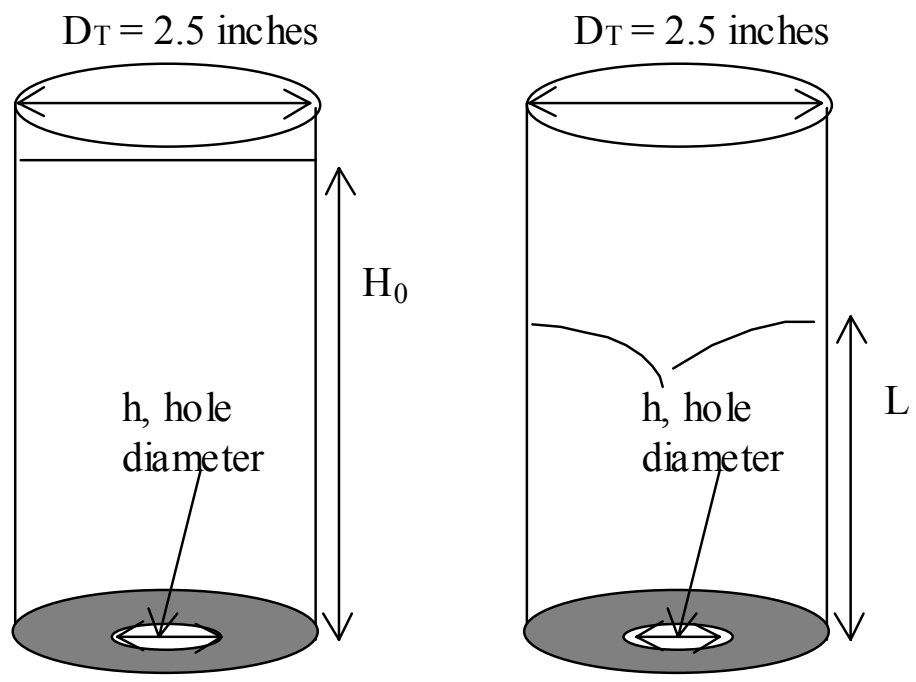

Figure 38: Internal angle of Friction Measurement Apparatus

According to Zenz (1960), the internal angle of friction, $\delta$, is related to the height that the dimple forms by Equation (38).

$$
\frac{L}{D_{T}}=\tan \delta
$$


A simple visual technique was used to determine the angle of wall friction of bed materials with galvanized sheet metal, the metal that was used in the fabrication of the shear vane. This procedure was found in Zenz (1960), and it was called angle of slide. This technique is not necessarily accepted by today's standards. Typically the Jenike shear cell is reported to be more accurate (Schulze, 2000). Shear cell measurements have been obtained for coke breeze. However, for most of the materials, the Zenz (1960) technique was chosen for its ease of implementation.

The procedure involved sprinkling test material onto a horizontal flat plate made out of the wall material. The plate was then tilted until the material starts to slide. The angle at which the material started to slide is the angle of slide, and we can use this to approximate the angle of wall friction. This set-up is illustrated in Figure 39.

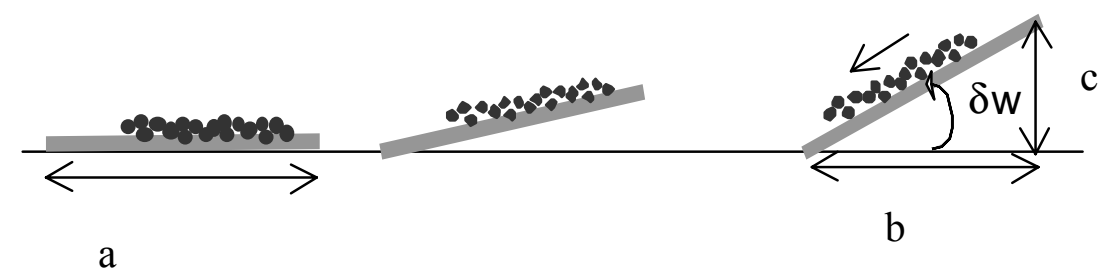

\section{Figure 39: Measurement of Angle of Wall Friction}

The length of the plate, a, is known. During these test it ranged from 11 to 10 3/4 inch. The angle of wall friction can be estimated using the following simple trigonometric relationships.

$$
\begin{gathered}
a^{2}=b^{2}+c^{2} \\
\tan \delta_{w}=\frac{c}{b}
\end{gathered}
$$

The product of the Janssen coefficient and the coefficient of friction, $\frac{\mu_{w}}{K}$, was calculated using Equation (40).

$$
\frac{\mu_{w}}{K}=\tan \delta_{w} \frac{1-\sin \delta}{1+\sin \delta}
$$


Equation (27), rewritten below for convenience, is used in the mixture momentum balance to develop equations for solids pressure.

$$
\tau_{s w}=\frac{\mu_{w}}{K} P_{s, z}
$$




\section{CHAPTER 4 RELATIVE COMPARISON OF FORCES IN A CFB AND THE JANSSEN COEFFICIENT}

In Section 3.7b two methods, that have been useful in sweeping through a large range of operating conditions in a short period of time, have been presented. These techniques along with the shear vane and wall probe tools were used to compare the relative magnitude of the forces across flow regimes and they were used to compare measured shear stress values to estimated solids wall shear stress values using the Janssen coefficient.

\subsection{Mass Circulation}

The mass flowrate of solids through the standpipe is primarily a function of the amount of air used in partial fluidization, but also depends on inventory, riser velocity, and system pressure.

Figure 40 is a typical plot showing how the circulation rate varied with changes in aeration. The flowrate of air was ramped from 50 to $405 \mathrm{scfh}$ at a rate of $20 \mathrm{scfh} / \mathrm{min}$. It has been shown in Section 3.7b that at this gradual ramp rate, measured variables obtained from the $\mathrm{CFB}$ reflect a near steady state relationship. That is, the time dependent effects can be neglected. Take note that the solids circulation values are 20second averages. The 20 -second average is necessary because of the high degree of natural variability in the circulation rates over a one second time span (Ludlow, 2002).

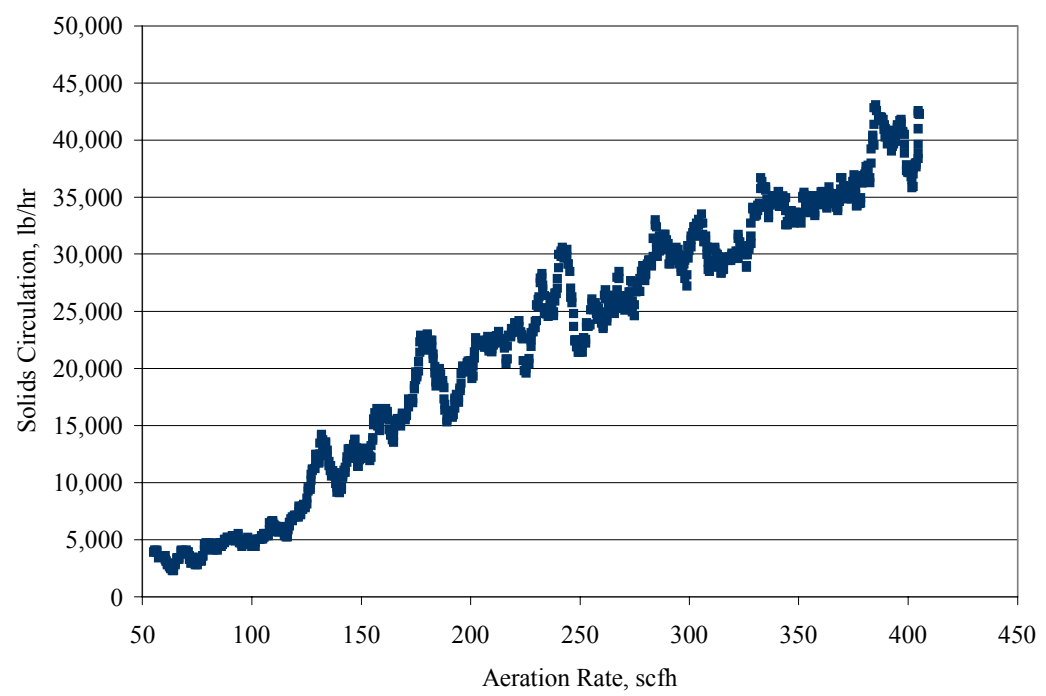

Figure 40: Solids Circulation versus Aeration $230 \mu \mathrm{m}$ Coke 


\subsection{Momentum Balance Components During an Aeration Ramp}

Using aeration ramps, the comparison of the forces in the momentum balance across flow regimes was made. As a result, it was seen that percentage of contribution of shear stress was heavily dependent on bed material. For coke breeze, solids phase shear stress and solids phase pressure drop $\left(-\Delta \mathrm{P}_{\mathrm{S}} / \mathrm{L}\right)$ were important forces in the momentum balance that could not be ignored. For coke breeze, the solids shear stress component was on the same order of magnitude as the gas phase pressure drop $\left(-\Delta \mathrm{P}_{g} / \mathrm{L}\right)$. However, for cork the shear stress component was always the smallest contribution to the momentum balance. It ranged from 9 to $2 \%$ of the total forces. This material dependence could be due from a large number of things such as particle size, sized distribution, shape, and density.

In Figure 41 the gas phase pressure drop $\left(-\Delta \mathrm{P}_{\mathrm{g}} / \mathrm{L}\right)$, wall shear stress $\left(-2 \tau_{\mathrm{sw}} / \mathrm{R}\right)$, and solids phase pressure drop $\left(-\Delta \mathrm{P}_{\mathrm{s}} / \mathrm{L}\right)$ are plotted as a function of solids circulation. The weight of the bed is assumed constant on this plot. The relative magnitude of these forces is compared as the aeration rate was ramped from 50 to $405 \mathrm{scfh}$. During the ramp the gas phase pressure drop $\left(-\Delta \mathrm{P}_{\mathrm{g}} / \mathrm{L}\right)$ ranged from 2 to 21 percent of the forces, the solids shear stress $\left(-2 \tau_{\mathrm{sw}} / \mathrm{R}\right)$ ranged from 28 to $6 \%$, and the solids phase pressure drop $\left(-\Delta \mathrm{P}_{\mathrm{s}} / \mathrm{L}\right)$ ranged from about 23 to $30 \%$ of the total forces. Because voidage is assumed constant and (Equation (7)), the weight of the bed never changed from $50 \%$ of the total force.

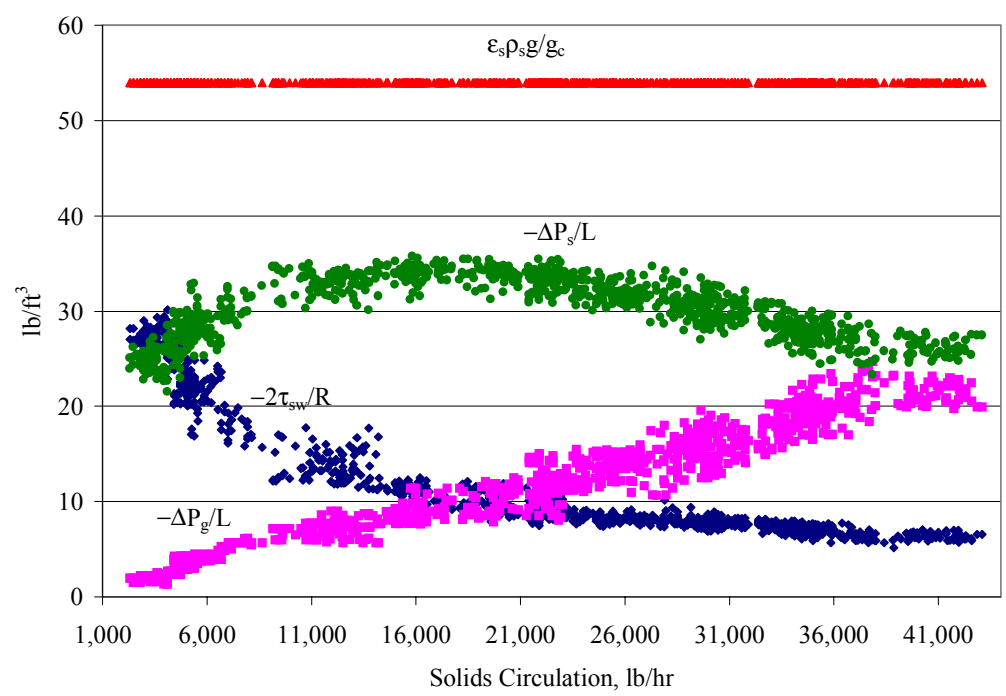

Figure 41: Momentum Balance Components versus Solids Circulation $230 \mu \mathrm{m}$ Coke 
In Figure 41 all of the forces are significant over some portion of the solids flow ramp. The shear stress $\left(-2 \tau_{\mathrm{sw}} / \mathrm{R}\right)$ and solids phase pressure drop $\left(-\Delta \mathrm{P}_{\mathrm{s}} / \mathrm{L}\right)$ are major components of the mixture momentum balance that must be quantified if we are to have a thorough understanding of standpipe hydrodynamics.

In Figure 42 the gas phase pressure drop $\left(-\Delta \mathrm{P}_{\mathrm{g}} / \mathrm{L}\right)$, wall shear stress $\left(-2 \tau_{\mathrm{sw}} / \mathrm{R}\right)$, and solids phase pressure drop $\left(-\Delta \mathrm{P}_{\mathrm{s}} / \mathrm{L}\right)$ are plotted as a function of solids circulation for cork. The weight of the bed is assumed constant on this plot. The relative magnitude of these forces is compared as the aeration rate was ramped in a steady state manner from 450 to $1200 \mathrm{scfh}$. During the ramp the gas phase pressure drop $\left(-\Delta \mathrm{P}_{\mathrm{g}} / \mathrm{L}\right)$ ranged from 11 to $42 \%$ of the forces, the wall shear stress $\left(-2 \tau_{\mathrm{sw}} / \mathrm{R}\right)$ ranged from 9 to $2 \%$, and the solids phase pressure drop ranged from about 33 to $4 \%$ of the total forces. Because solids pressure drop $\left(-\Delta \mathrm{P}_{\mathrm{s}} / \mathrm{L}\right)$ is estimated by difference (Equation (7)), the weight of the bed never changed from $50 \%$ of the total force.

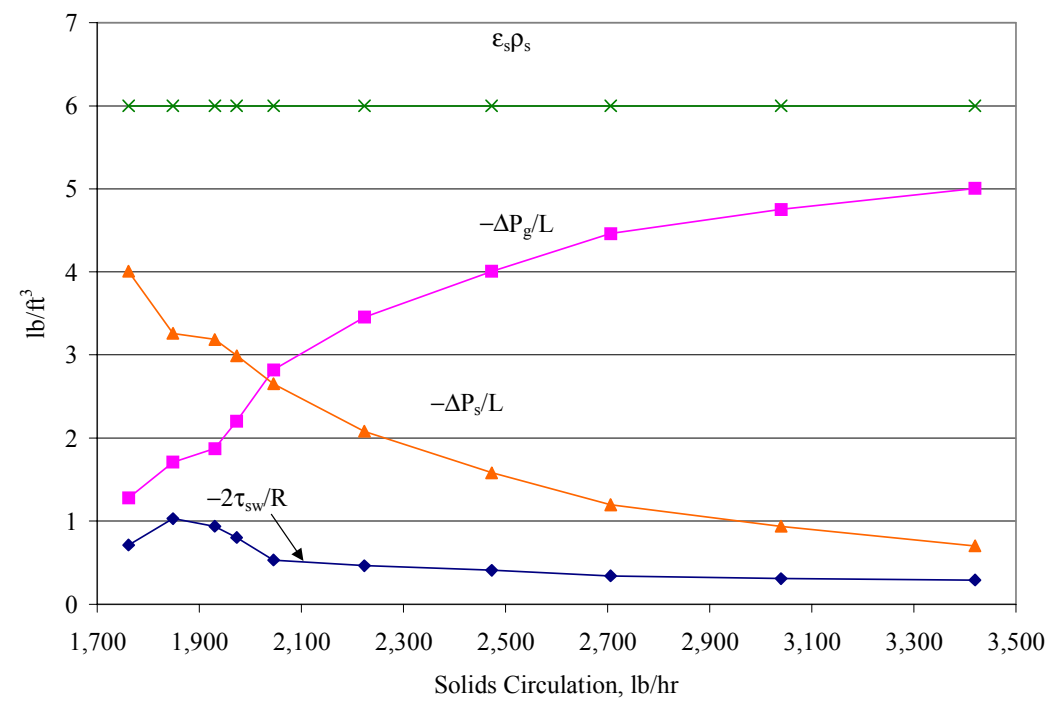

\section{Figure 42: Momentum Balance Components Versus Aeration, Steady States, Cork}

In Figure 42, the momentum balance components follow trends similar to Figure 41. Differences between Figure 42 and 41 are that Figure 41 is for coke breeze measured by the shear vane using a transient ramp and that Figure 42 is for cork measured by the wall shear probe using a steady state ramp. Further, in Figure 41 the measurements are located at about 7', and in Figure 42 the measurements are at about 13.5'. Unlike coke 
breeze, the shear stress component for cork is low in magnitude compared to gas pressure drop per unit length.

In Table 14 relative magnitude of the forces is compared. An attempt to estimate the flow regime based on gas pressure drop $\left(-\Delta \mathrm{P}_{\mathrm{g}} / \mathrm{L}\right)$ and slopes of the shear and solids pressure drop components has been made. For example, in Figure 41 at low flows the shear stress component dropped steeply at which time the solids pressure component increased with increasing solids circulation rate. This was interpreted to be a transitional packed regime at which time the bed was in slip-stick flow. Above circulation rates that corresponded to transitional packed regime, the shear stress was relatively constant. The bed was interpreted to be packed under these conditions. At higher flows, all three components approached a constant state. This state was said to be a fluidized regime. The only conflicting problem was that the gas pressure drop in the fluidized regime was much less than the weight of the bed for coke breeze.

Table 14: Comparison of Relative Magnitude of Forces (\% of Total Force) for Cork and Coke Breeze

\begin{tabular}{|c|c|c|c|c|c|}
\hline Material & $\underline{\text { Flow }}$ & $\underline{-2 \tau_{\mathrm{sw}} / \mathrm{R}}$ & $\underline{-\Delta \mathbf{P}_{g}} / \underline{\mathbf{L}}$ & $\underline{-\Delta \mathbf{P}_{s}} \mathbf{s} \underline{\mathbf{L}}$ & $\underline{\varepsilon}_{s} \underline{\rho}_{\mathrm{s}} \mathbf{g} / \mathbf{g}_{\mathrm{c}}$ \\
\hline Coke & $\begin{array}{l}\text { Transitional } \\
\text { Packed }\end{array}$ & $27-10 \%$ & $1-8 \%$ & $22-32 \%$ & $50 \%$ \\
\hline Coke & Packed & $10-5 \%$ & $8-20 \%$ & $32-25 \%$ & $50 \%$ \\
\hline Cork & $\begin{array}{l}\text { Transitional } \\
\text { Packed }\end{array}$ & $6-9 \%$ & $11-15 \%$ & $33-26 \%$ & $50 \%$ \\
\hline Cork & Packed & $9-2 \%$ & $1-43 \%$ & $2-5 \%$ & $50 \%$ \\
\hline Cork & Fluidized & $2 \%$ & $43 \%$ & $5 \%$ & $50 \%$ \\
\hline
\end{tabular}

\subsection{Differential Solids Pressure and Solids Wall Shear Stress Estimates}

Aeration ramps were used to compare measured shear stress values with the shear stress predicted using the product of the Janssen coefficient and coefficient of friction. Using this product to predict wall shear stress resulted in values higher than four times the measured values. If the product of the Janssen coefficient and coefficient of friction was adjusted such that the predicted values matched the measured values, a value of 0.003 was found to work well for both cork and coke breeze. This result was startling due to its magnitude and the fact that the same value worked well for both materials. 
This suggests that the product of the Janssen coefficient and coefficient of friction, which are measured under non-aerated, incipient flow conditions, may not be the correct parameters to be used in the standpipe of a CFB.

Before discussing the comparison of the predicted shear stress and measured shear stress values, the method of predicting shear stress must be outlined in detail. As discussed in section 2.2a, Picciotti (1995) suggests that the solids pressure is related to the wall shear stress by Equation (27), which is rewritten below for reference.

$$
\tau_{s w}=\frac{\mu_{w}}{K} P_{s, z}
$$

Picciotti (1995) substituted Equation (27) into the microscopic form of the mixture momentum balance, Equation (6), which is rewritten below for reference.

$$
-\frac{\partial P_{s z}}{\partial z}-\frac{\partial P_{g}}{\partial z}+\frac{4 \tau_{s w}}{D}-\rho_{s} \varepsilon_{s} \frac{g}{g_{c}}=0
$$

He integrated this equation from the top of the bed to any height, z. This resulted in an equation that gave solids pressure as a function of height, Equation (28). Several assumptions were used such as constant solids volume fraction and that the bed in an active state of stress. Further, it was assumed that the solids pressure at the top of the bed is zero, and the gas pressure drop per unit length is constant. Under the conditions of this study, the gas pressure drop per unit length is not always constant due to inventory heights and staged aeration.

To improve this assumption, Equation (41) has been developed by integrating the mixture momentum balance between two arbitrary heights. A complete derivation of Equation (41) can be found in Appendix A.2b. Unlike in the derivation of Equation (28), Equation (41) was derived with a positive z-coordinate axis pointing up against gravity.

$$
\left.P_{s z}\right|_{z=z 1}=\frac{D K}{4 \mu_{w}}\left(e^{\frac{-4 \mu_{w}}{D K}\left(z_{2}-z_{1}\right)}\right)\left(\frac{\Delta P_{g}}{\Delta z}+\left.\frac{4 \mu_{w}}{D K} P_{s z}\right|_{z=z 2}-\rho_{s} \varepsilon_{s} \frac{g}{g_{c}}\right)-\frac{D K}{4 \mu_{w}}\left(\frac{\Delta P_{g}}{\Delta z}-\rho_{s} \varepsilon_{s} \frac{g}{g_{c}}\right)(41)
$$

Like Equation (28), assumptions made in the derivation of Equation (41) are constant solids volume fraction, constant gas pressure drop $\left(-\Delta \mathrm{P}_{\mathrm{g}} / \mathrm{L}\right)$, and that the bed is in an active state of stress. Because of the assumption of constant gas pressure drop ($\left.\Delta \mathrm{P}_{\mathrm{g}} / \mathrm{L}\right)$, this equation is applied over several small sections of the standpipe where measured values of the gas pressure are known and the incremental values of the solids 
pressure along the standpipe can therefore be determined. The procedure used to determine the solids pressure is a step wise one, starting at the top of the bed. Assuming a zero solids pressure at the top of the bed, a solids pressure at some interval into the bed is calculated. Using this solids pressure at the bottom of the first interval as the top pressure for the next interval, solids pressures are calculated until the location of intent is reached. Also, equations (41) and (27) can be used together to estimate a solids wall shear stress. For clarity this method of estimating shear stress and solids pressure drop ($\left.\Delta \mathrm{P}_{\mathrm{s}} / \mathrm{L}\right)$ will be referred to as Method II.

In addition to the method described above, the solids pressure drop $\left(-\Delta \mathrm{P}_{\mathrm{s}} / \mathrm{L}\right)$ can be approximated using measured shear stress values and Equation (7). For clarity this method of estimating solids pressure drop $\left(-\Delta \mathrm{P}_{\mathrm{s}} / \mathrm{L}\right)$ will be referred to as Method $\mathrm{I}$.

In summary, two different methods have been presented to estimate solids phase wall shear stress and solids phase pressure drop.

Method I is to experimentally measure gas phase pressure and solids phase shear stress of the control volume, and then to use these measurements to calculate the solids phase pressure drop assuming a constant solids volume fraction and using Equation (7).

$$
\frac{\Delta P_{s z}}{\Delta z}=-\rho_{s} \varepsilon_{s} \frac{g}{g_{c}}+\frac{4 \tau_{s w}}{D}-\frac{\Delta P_{g}}{\Delta z}
$$

Method II is to measure gas phase pressure drop at increments along the standpipe and measure the height of the bed. Then equation (41) is applied successively down the standpipe until the solids pressure across the control volume of interest is known. These solids pressure values can be used with equation (27) to find shear stress. Take note that the second method is independent of direct shear stress measurements, and is the typical approach of researchers (Leung, 1985; Mountziaris, 1990; Picciotti, 1995). Further, both methods assume a constant solids volume fraction and use experimentally measured gas pressure differential.

In Figure 43 the solids phase pressure drop as determined by both methods is plotted versus circulation rate. The two methods utilize experimentally determined gas pressure drop and assume a constant void fraction. Solids pressures $\left(-\Delta \mathrm{P}_{\mathrm{s}} / \mathrm{L}\right)$ calculated using Method II were considerably lower in value than the solids pressure from shear stress measurements, Method I. For lower circulation rates Method I increases with 
increasing mass circulation, while the Method II decreases with increasing mass circulation rate.

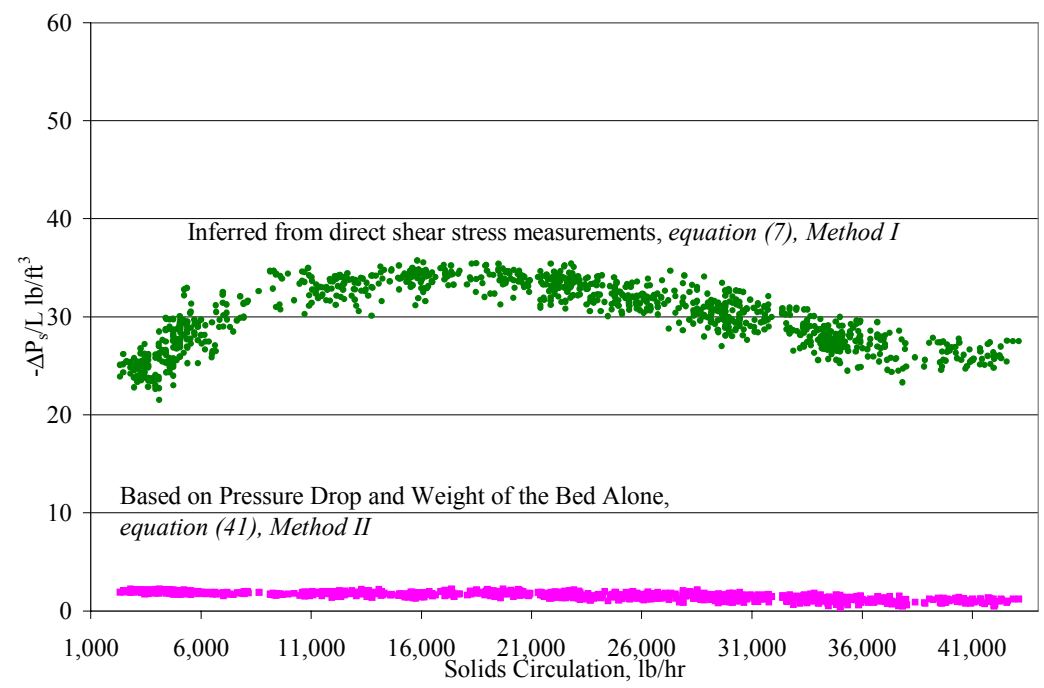

\section{Figure 43: Estimated Values of $\Delta P_{s} / L$ versus Mass Circulation for $230 \mu m$ coke}

In Figure 44 the predicted and measured values of the shear stress as a function of circulation rate are plotted. Here the predicted values over estimate the measured values. Similarly to Figure 43, the results show very different trends at mass circulation rates below $10,000 \mathrm{lb} / \mathrm{hr}$ where the measured values drop more steeply with increasing mass circulation.

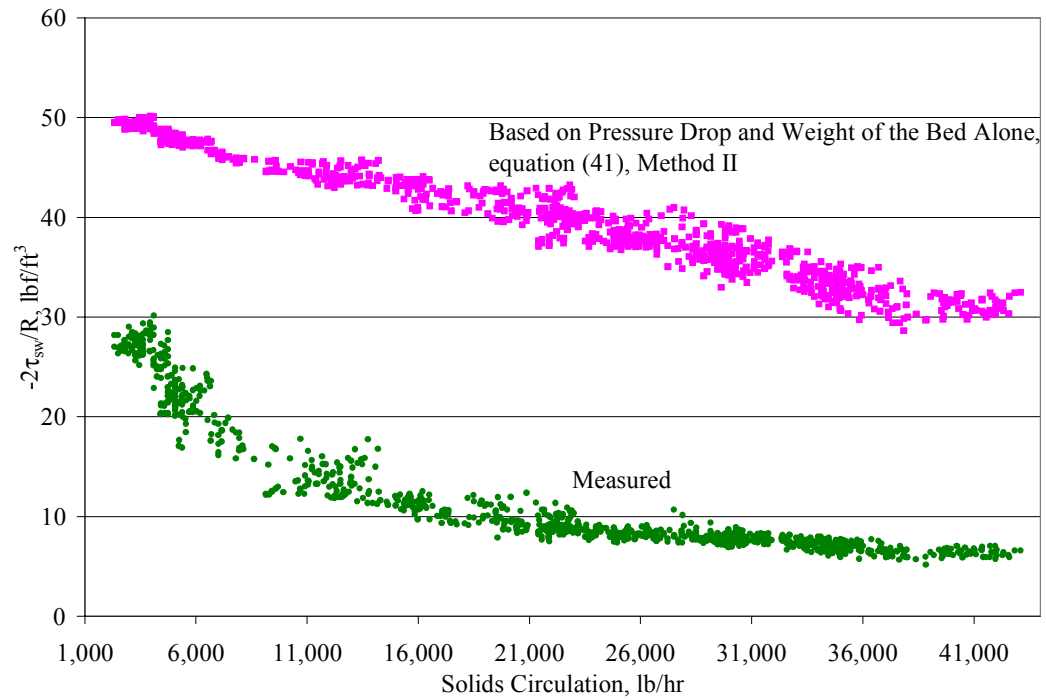

Figure 44: Measured and Estimated Values of $-2 \tau_{\mathrm{sw}} / \mathbf{R}$ versus Mass Circulation 230 $\mu \mathrm{m}$ Coke 
An explanation for this difference in trends for the two methods in Figures 43 and 44 may be explained by a regime change. It is the same initial region in the plot. Method II assumes a packed regime and an active state of stress. At the lower circulation rates which correspond to lower aeration rates, it is plausible that the bed is transitionally packed (slip-stick flow) and not in an active state.

In Figure 45 the solids phase shear stress as measured and from Method II is plotted versus solids volumetric flux. The predicted method used experimentally determined gas pressure drop and an assumed a constant solids volume fraction. Direct shear stress measurements are in gray. Shear stresses calculated with Method II using a $\mu_{\mathrm{w}} / \mathrm{K}$ of 0.059 are in black, and were higher in value then the measured values as in Figure 44. The black filled-in circles and the black line correspond to estimated shear stress such that $\mu_{\mathrm{w}} / \mathrm{K}$ was changed until the predicted fitted the measured shear stress. The product of the Janssen coefficient and coefficient of friction appeared to change with increasing solids volumetric flux until after a point where it reached a limiting value of 0.003 .

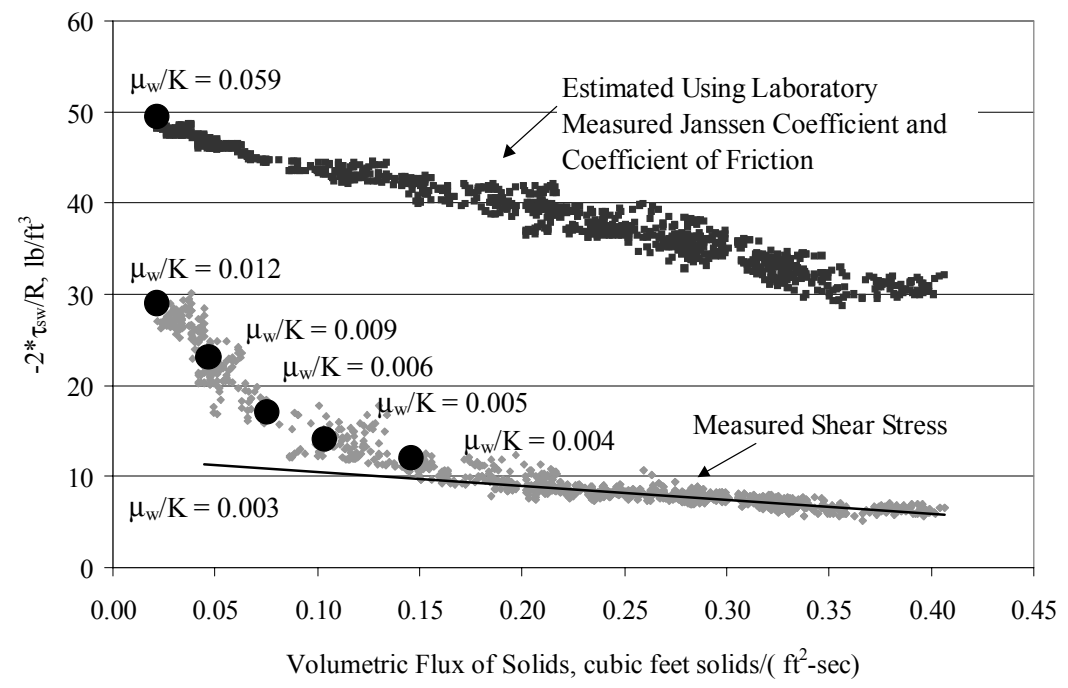

\section{Figure 45: Measured and Estimated Values of $-4 \tau_{\mathrm{sw}} / \mathrm{D}$ versus Solids Circulation, Coke Breeze}

The product of the Janssen coefficient and coefficient of friction that fitted the measured shear stresses was much lower then the product measured by a Jenike shear cell, 0.059. The Jenike shear cell measurements are under non-aerated incipient flow 
conditions. Most of the conditions in Figure 45 are aerated and high fluxes. Further, it is has been reported in the literature that the product of the Janssen coefficient and the coefficient of friction is a function of the solids volume fraction (Abou-Chakr, 1999). At lower solids volumetric fluxes, the bulk density could be changing.

In Figure 46, the Jenike shear cell measurements of the angle of wall friction, internal angle of friction, and bulk density have been plotted versus the normal stress applied to the cell. Due to the consolidation of the solids, the bulk density increased with increasing normal stress. The shear cell measurements showed that the internal angle of friction decreased with increasing normal stress, and that the angle of wall friction decreased steeply and leveled off at a constant value of $15^{\circ}$ with increasing normal stress. This suggested that the product of the coefficient of friction and Janssen coefficient varied with normal stress or bulk density, Figure 47.

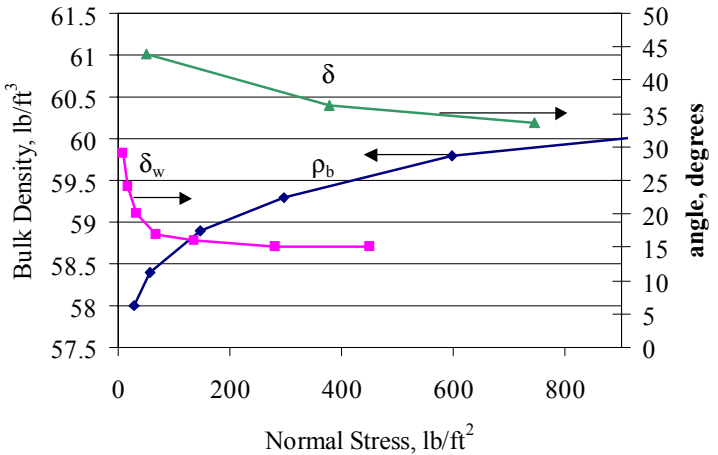

Figure 46: Jenike Shear Cell Measurements of Coke Breeze

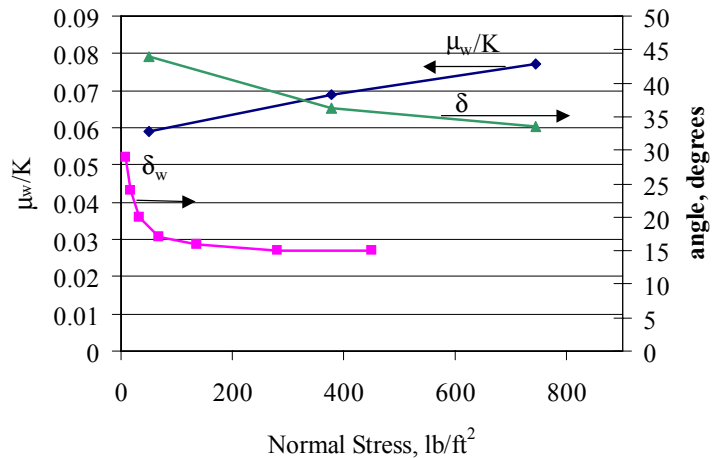

Figure 47: The Variation of the Product of the Coefficient of Friction and the Janssen Coefficient with Normal Stress

In Figure 48 the solids phase pressure drop $\left(-\Delta \mathrm{P}_{\mathrm{s}} / \mathrm{L}\right)$ as determined by difference (Method I) and from Equation (41) (Method II) is plotted versus solids volumetric flux. The two methods utilize experimentally determined gas pressure drop and assume a constant void fraction. Solids pressure drop $\left(-\Delta \mathrm{P}_{\mathrm{s}} / \mathrm{L}\right)$ from shear stress measurements are in gray. Solids pressure drop $\left(-\Delta \mathrm{P}_{\mathrm{s}} / \mathrm{L}\right)$ calculated using Method II using a $\mu_{\mathrm{w}} / \mathrm{K}$ of 0.059 are in black, and were lower in value then the solids pressure drop $\left(-\Delta \mathrm{P}_{\mathrm{s}} / \mathrm{L}\right)$ from shear stress measurements. As with the shear stress, the black filled-in circles correspond to estimated solids pressure drop $\left(-\Delta \mathrm{P}_{\mathrm{s}} / \mathrm{L}\right)$ such that $\mu_{\mathrm{w}} / \mathrm{K}$ was changed until the predicted solids pressure drop $\left(-\Delta \mathrm{P}_{\mathrm{s}} / \mathrm{L}\right)$ fitted the method using the experimental shear stress 
measurements (Method I). The product of the Janssen coefficient and coefficient of friction appear to change with increasing fluxes and come to a limiting value of 0.003 . Since solids pressure calculated by either method is strongly dependent on the shear stress of either method, the same fitted values of $\mu_{\mathrm{w}} / \mathrm{K}$ that worked for shear stress agree well for solids pressure.

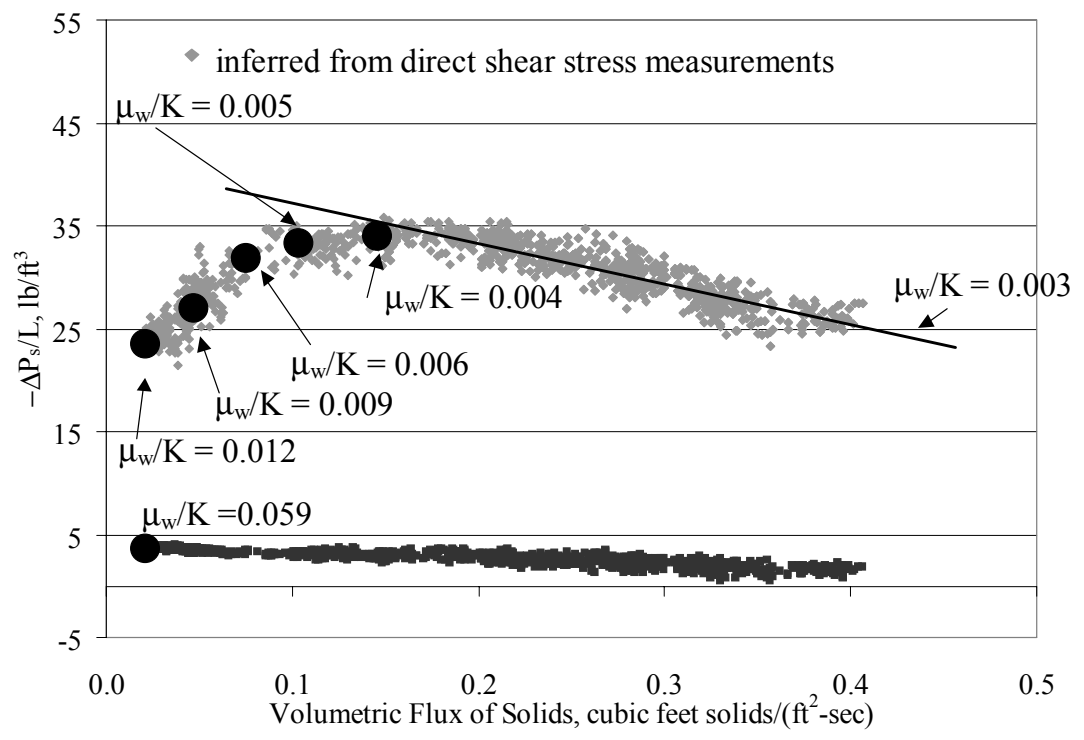

Figure 48: Estimated Values of $-\Delta \mathbf{P}_{s} / L$ versus Solids Volumetric Flux

The estimates using a coefficient value of 0.003 were also good for cork (Figures 49 and 50), except for very low circulation rates where the shear stress decreased. In Figure 49 the $\mu_{\mathrm{w}} / \mathrm{K}$ for the predicted shear stress was adjusted such that the estimated shear stress fitted the measured. These values are in green triangles and overlay the measured values which are blue diamonds. The corresponding $\mu_{\mathrm{w}} / \mathrm{K}$ are plotted in black on the right hand y-axis. For cork, the product of the Janssen coefficient and coefficient of friction necessary to fit the data increased with increasing flux. This is the opposite of the trend seen with coke breeze. It is hard to conjecture on the meaning of this trend, because shear cell measurements for this material have not yet been obtained. 


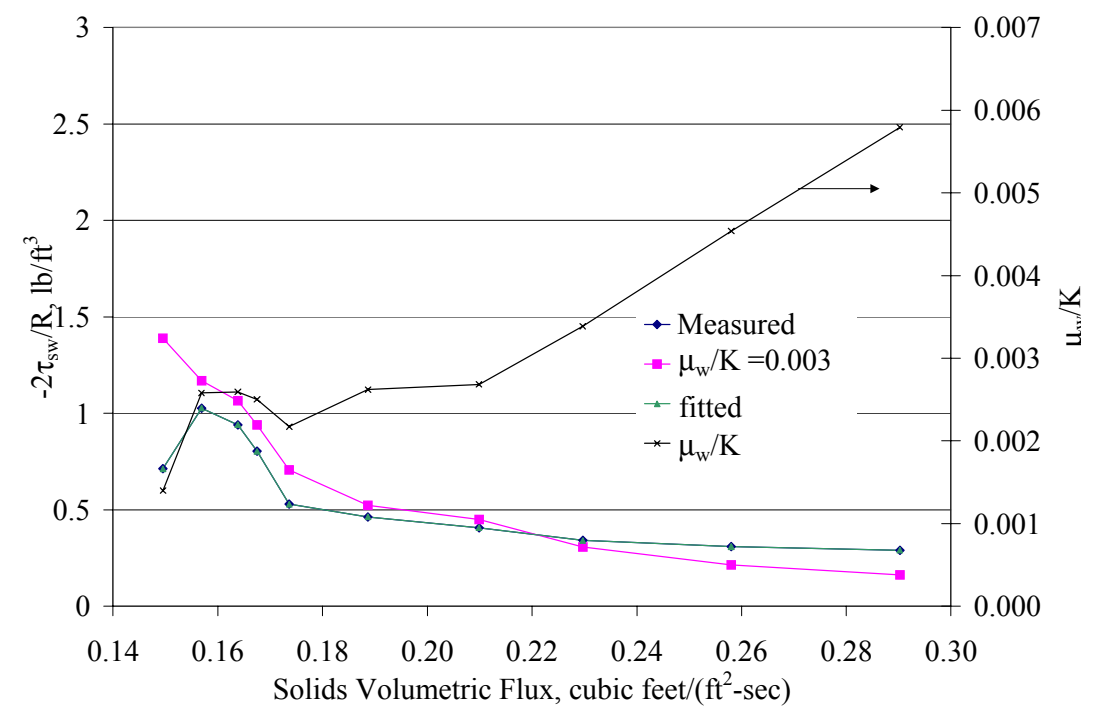

Figure 49: Measured and Estimated Values of $-2 \tau_{\text {sw }} / \mathbf{R}$ versus Solids Volumetric Flux, Cork

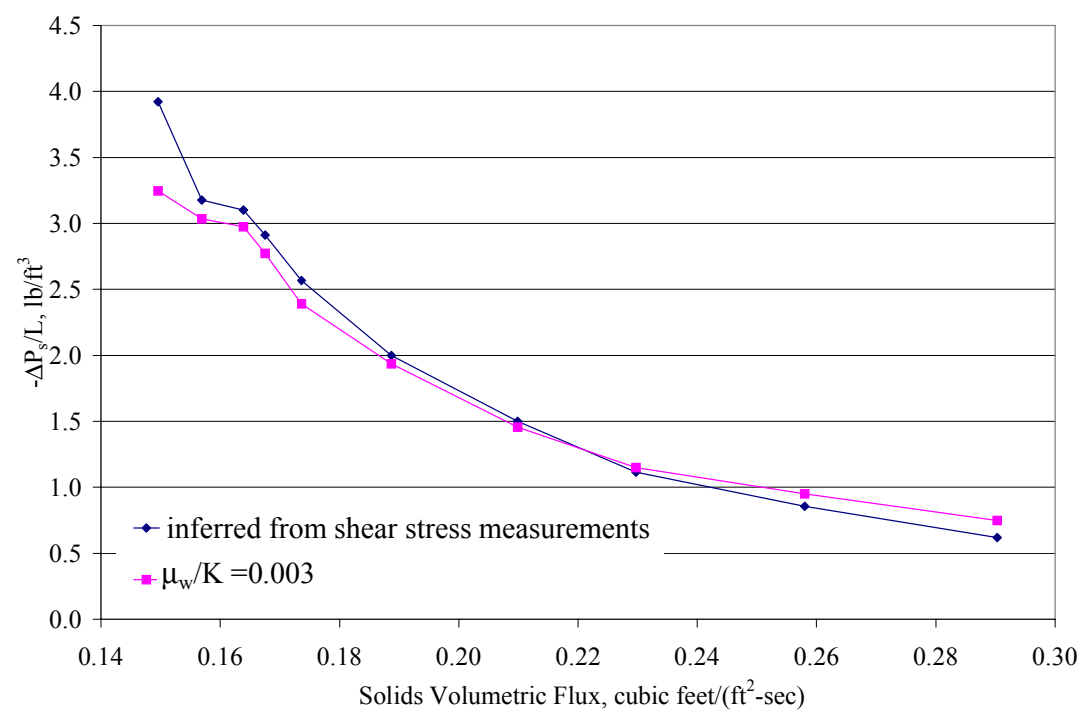

Figure 50: Measured and Estimated Values of $-\Delta \mathbf{P}_{\mathrm{s}} / \mathbf{L}$ versus Solids Volumetric Flux, Cork

Measurements of $\mu_{\mathrm{w}} / \mathrm{K}$ are shown in Table 15. Note that the measured values are much higher then those suggested by McCabe (1993), who suggests angles between $15^{\circ}$ and $30^{\circ}$ for free-flowing granular materials. Further, the measurement using the shear cell is significantly lower then the value obtained using the Zenz (1960) technique. The different values listed for coke breeze shows how the material properties change over 
time. Over time, the fines level decreased. Fines were intentionally added to the material referred to as coke-coarse-11/30. The resulting material is listed as Coke-coarse+fines12/6. The corresponding internal angle of friction increased.

Table 15: Estimated values of the Janssen Coefficient

\begin{tabular}{|c|c|c|c|}
\hline Material & $\begin{array}{l}\text { Angle of Internal } \\
\text { Friction, } \\
\quad{ }^{\circ} \delta\end{array}$ & $\begin{array}{l}\text { Angle of Wall } \\
\text { Friction for } \\
\text { galvanized sheet } \\
\text { metal, }{ }^{\circ}, \delta_{w}\end{array}$ & $\begin{array}{c}\frac{\mu_{w}}{K} \text { for } \\
\text { galvanized } \\
\text { sheet metal, } \\
\text { Equation }(41)\end{array}$ \\
\hline Coke Breeze-10/31 & 74.2 & 34.2 & 0.013 \\
\hline Coke Breeze-L-20 New & 76.4 & 30.8 & 0.008 \\
\hline Coke-coarse-11/30 & 73.1 & 34.7 & 0.0153 \\
\hline Coke-coarse+fines-12/6 & 74.4 & 34.4 & 0.0129 \\
\hline $\begin{array}{l}\text { Coke-coarse+fines- } \\
\text { 12/6-Shear Cell }\end{array}$ & $\begin{array}{c}\text { ranged between } \\
33.57-43.87\end{array}$ & 29-18 & 0.059-0.077 \\
\hline Sand 70/140 & 65.1 & 30.9 & 0.029 \\
\hline glass beads & 56.1 & 20.5 & .035 \\
\hline PVC new & 77.5 & 40.2 & .0101 \\
\hline Cork 20-40 & 74.3 & 37.2 & 0.014 \\
\hline
\end{tabular}

The angle of internal friction and the angle of wall friction give insight into when the material is stationary and when it moves. The angle of internal friction described carefully in Appendix A.3. The angle of internal friction is the angle that the yield locus makes with the normal stress axis on the Mohr diagram. If the stress state of the material is such that the Mohr circle touches the yield locus, the material will move (Brown, 1970).

According to Picciotti (1995) these angles can give insight into whether the bed moves at the wall or if there is a stationary film at the wall and the bed moves internally. He states that if the angle of wall friction is greater than the angle of internal friction the solids will be stationary at the wall and the bed will move internally. On the other hand, if the angle of wall friction is less than the angle of internal friction the solids will move along the wall. The measurements in Table 15 indicate that the angle of wall friction is less then the internal angle of friction for all materials studied. Therefore, all materials studied should slide at the wall. 


\section{CHAPTER 5 DEPENDENCE OF SOLIDS WALL SHEAR STRESS AND SOLIDS PRESSURE ON OPERATING CONDITIONS}

In Chapter 4 the relative magnitude of the forces was studied, and the experimental results were compared to results obtained using the product of the Janssen coefficient and coefficient of friction. In this chapter, the effects of key variables, discussed in Chapter 2 and Chapter 4, were tested. Furthermore, solids wall shear stress has been measured under a large variety of operating conditions. This chapter discusses the effects of different CFB operational variables such as mass circulation, standpipe height, and level of fines on shear stress and solids pressure. A list of variables has been provided in Table 16. A mixture of experimental techniques ranging from aeration ramps to statistical factorial studies has been used in this study. Both cork and coke breeze have been studied. The shear vane and the wall shear probe have been used.

Table 16 organizes all of the work of this study into three sections. Tests that were designed with the purpose in mind to test the theory developed in Chapters 2 and 4 are described in the first section. Transient aeration ramps that gave insight into the effect of gas pressure drop per unit length, bed material, bed compaction, and ramp direction are discussed in the second section. A few CFB operating variable tests are described in the last section. 
Table 16: Operational Variables Tested

\begin{tabular}{|c|c|c|}
\hline Purpose of Test & $\underline{\text { Variables Studied }}$ & Experimental Method \\
\hline \multirow{3}{*}{$\begin{array}{c}\text { Test Theoretical Variables } \\
5.1\end{array}$} & Solids Circulation Rate & \multirow[t]{3}{*}{ Factorial Design } \\
\hline & Standpipe Height & \\
\hline & $\Delta \mathrm{P}_{\mathrm{g}} / \mathrm{L}$ & \\
\hline \multirow[t]{6}{*}{ Qualitative Study } & Move Air Location & \multirow[t]{6}{*}{ Transient Ramps } \\
\hline & Bed Material & \\
\hline & Solids Circulation Rate & \\
\hline & $\Delta \mathrm{P}_{\mathrm{g}} / \mathrm{L} / \varepsilon_{\mathrm{s}}$ & \\
\hline & Bed Compaction & \\
\hline & Ramp Direction & \\
\hline \multirow[t]{10}{*}{ CFB Operational Variables } & Riser $\Delta \mathrm{P}$ & \multirow[t]{10}{*}{ Factorial } \\
\hline & Solids Circulation Rate & \\
\hline & Standpipe Height & \\
\hline & Gas Velocity in the Riser & \\
\hline & Aeration in the Loopseal & \\
\hline & $\begin{array}{l}\text { Gas Velocity into the } \\
\text { Standpipe }\end{array}$ & \\
\hline & $\begin{array}{c}\text { Concentration of Fines in } \\
\text { Coke }\end{array}$ & \\
\hline & Location of Move Aeration & \\
\hline & Staged Aeration & \\
\hline & Ramp Direction & \\
\hline
\end{tabular}




\subsection{Testing Theoretical Variables}

As described in Chapter 2, Leung and Jones (1985) suggest using a friction factor to estimate shear stress for a fluidized regime Equation (42). Others suggest that the shear stress for a fluidized regime is negligible (Knowlton, 1986; Mountziaris and Jackson, 1990). As a result, shear stress for a fluidized regime is dependent on solids volume fraction and solids circulation.

$$
\tau_{w}=\frac{1}{2} f \varepsilon_{s} \rho_{s} u_{s}^{2}
$$

As discussed in Chapters 2 and 4, for packed bed states researchers relate the shear stress to the solids pressure by Equation (27) (Leung, 1985; Mountziaris, 1990; Picciotti, 1995). This equation assumes a packed regime and an active state of stress.

$$
\tau_{s w}=\frac{\mu_{w}}{K} P_{s z}
$$

Equation (27) is then substituted into the steady state mixture momentum balance, and it is integrated between two different heights to give Equation (41). This development can be found in Chapter 4.

$$
\left.P_{s z}\right|_{z=z 1}=\frac{D K}{4 \mu_{w}}\left(e^{\frac{-4 \mu_{w}}{D K}\left(z_{2}-z_{1}\right)}\right)\left(\frac{\Delta P_{g}}{\Delta z}+\left.\frac{4 \mu_{w}}{D K} P_{s z}\right|_{z=z 2}-\rho_{s} \varepsilon_{s} \frac{g}{g_{c}}\right)-\frac{D K}{4 \mu_{w}}\left(\frac{\Delta P_{g}}{\Delta z}-\rho_{s} \varepsilon_{s} \frac{g}{g_{c}}\right)(41)
$$

Using Equations (41) and (27) gives a method for estimating shear stress. From Equation (41), shear stress for a packed regime is dependent on axial location in the bed, gas pressure drop per unit length, and solids volume fraction.

Chapter 4 discusses the magnitude and effect of the proportionality constant, $\mu_{\mathrm{w}} / \mathrm{K}$, in Equations (41) and (27). This section discusses the effects of the independent variables in Equations (41) and (42). A series of steady state runs were conducted to test the dependencies described above.

All data in this section was taken with cork in the standpipe at a level of 13.5'. In general shear stress measurements were made with the wall shear probe.

\section{1a The Effects of Solids Circulation Rate on a Fluidized Regime}

This study was designed to test Equation (42), which suggests that for a fluidized regime the shear stress is related to the solids velocity squared. Five different circulation 
rates were achieved while holding the gas pressure drop $\left(-\Delta \mathrm{P}_{\mathrm{g}} / \mathrm{L}\right)$ constant at $4 \mathrm{lb} / \mathrm{ft}^{3}$. This selected gas pressure drop $(-\Delta \mathrm{Pg} / \mathrm{L})$ of $4 \mathrm{lb} / \mathrm{ft}^{3}$ was selected because it is approaching the weight of the bed that is approximately $5-5.5 \mathrm{lb} / \mathrm{ft}^{3}$. Higher values were not used, because of the concern of slugs forming in the standpipe. In Figure 51 the shear stress as measured by the wall probe at 13.5', as measured by a shear vane at $8^{\prime}$, and as measured by a shear vane at $23^{\prime}$ in the standpipe is plotted versus circulation rate. In Figure 52 the shear stress as measured by the wall probe is plotted alone versus solids circulation.

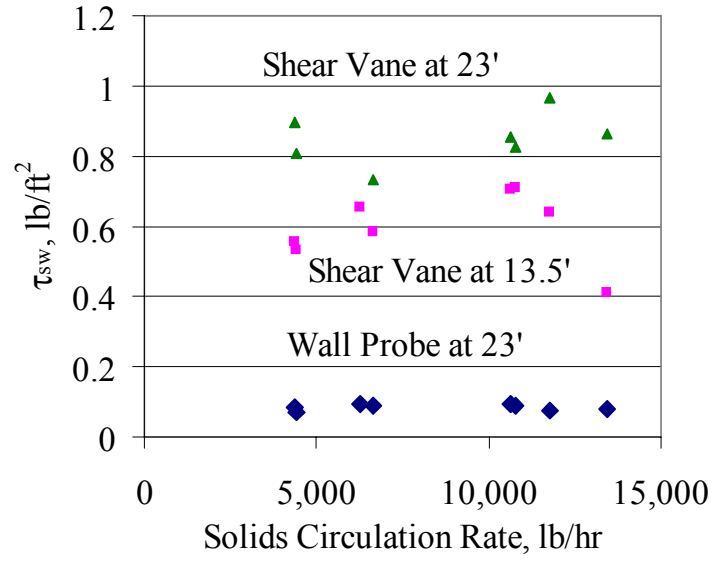

Figure 51: Shear Stress Measured by the Shear Vane and Wall Probe for a Fluidized Regime, Cork

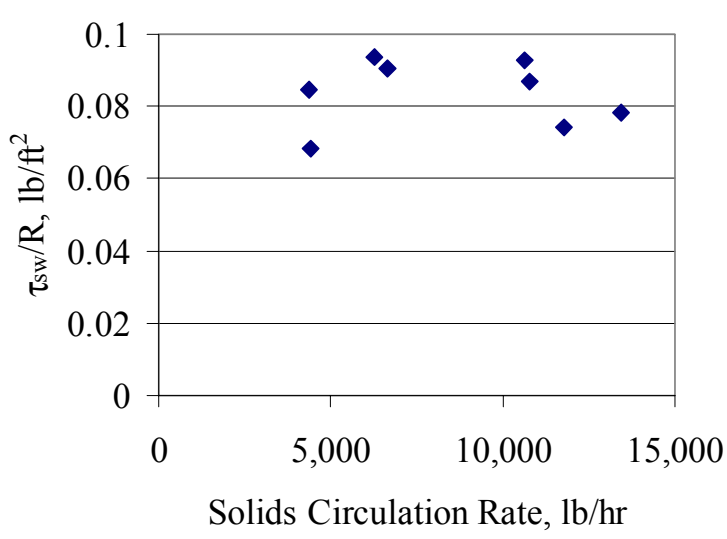

Figure 52: Shear Stress Measured by the Wall Probe for a Fluidized Regime, Cork

In Figure 51, the shear vane measurements are higher than the wall probe measurements. One explanation could be that parasitic drag is not accounted for in the shear vane measurements. However, as discussed in Section 3.4c, parasitic drag only accounted for $50 \%$ of the total force measured by the shear vane. Visual observations of the cork in the standpipe indicate that at high circulation rates the cork is stationary at the wall and is moving in the center. The fact that conditions at the wall are much different then in the center of the pipe may be a more plausible explanation for the differences in the shear vane and wall probe measurements in Figure 51. In Figure 52 the shear stress is very low in agreement with Knowlton (1986) and Mountziaris (1990). We cannot measure any significant change with solids circulation.

The momentum balance components are plotted in Figure 53. The shear stress component is the smallest component in the momentum balance for cork in a fluidized regime. The shear stress is measured at $13.5^{\prime}$ by the wall probe. This is different then 
results for coke breeze under packed regimes in Chapters 4 where the shear stress component at lower aeration rates was larger than gas pressure drop per unit length.

From this study, it is apparent that shear stress is small in this regime, and does not vary measurably with circulation rate. The dependence suggested by Equation (41) is either incorrect or the wall probe is not sensitive enough to pick up the dependence.

It has been found that there is very little difference between the shear stress and the probe zero. To illustrate this, when the standpipe was in a fluidized state, the valve above the wall probe in Figure 10 was closed, and the bed level was allowed to drop below the wall probe. This was done to give a direct comparison of the shear of a fluidized state with no shear. In Figure 54 the shear stress component is plotted versus time during the time period of interest.

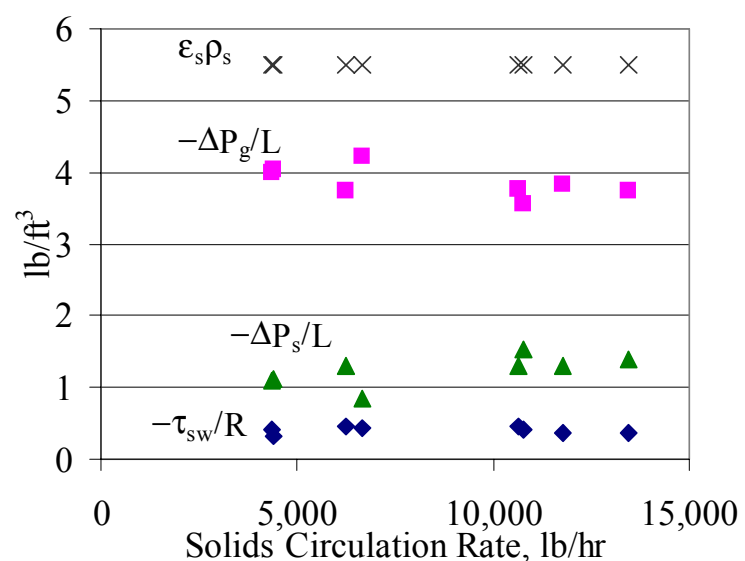

Figure 53: Momentum Balance Components versus Solids Circulation for a Fluidized Regime, Cork

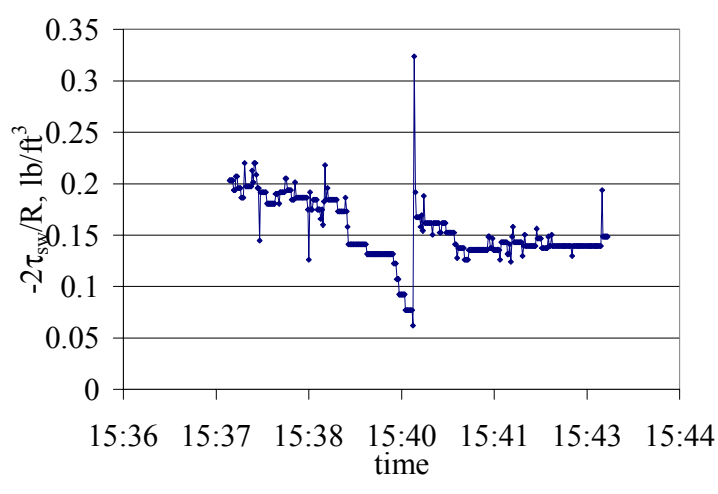

Figure 54: Shear Stress Component Zero, Cork

In Figure 54, the lowest shear stress component measured was approximately $0.062 \mathrm{lb} / \mathrm{ft}^{3}$. This corresponds to the point when the bed has been drained below the probe. The highest shear stress component measured was about $0.2 \mathrm{lb} / \mathrm{ft}^{3}$. This corresponds to a fluidized state. This shows that there is a measurable though very small difference between no shear and shear due to a fluidized regime.

\section{1b The Effect of Solids Circulation Rate and Standpipe Height on a Packed Regime}

From Equations (41) and (27) estimated values of shear stress for a packed bed regime are dependent on axial location in the bed, gas pressure drop $\left(-\Delta \mathrm{P}_{\mathrm{g}} / \mathrm{L}\right)$, and solids 
volume fraction. Further, studies presented in Chapters 4 and 5 suggest that shear stress is dependent on solids circulation. As a result, two different studies were conducted to understand standpipe height, gas pressure drop $\left(-\Delta \mathrm{P}_{\mathrm{g}} / \mathrm{L}\right)$ and solids circulation rate. The three independent variables could not be lumped together in one experiment, because we could not vary them independently. As a result, the effects of solids circulation and gas pressure drop $\left(-\Delta \mathrm{P}_{\mathrm{g}} / \mathrm{L}\right)$ on shear stress for a packed regime was studied, and it is discussed in the next section. Furthermore, the effects of solids circulation and standpipe height on shear stress in a packed bed regime was studied and is discussed in this section. Standpipe height was selected because the location of the probe is fixed. Therefore, to vary the axial location of the measured shear stress, the height was varied.

In Table 17 the independent variables and settings are listed, and the results are listed in Table 18. The shear stress was measured at $13.5^{\prime}$ by the wall shear probe. The test was a $2^{2}$ factorial, randomized, and fully duplicated. In Figure 55 and 56 the duplicates are portrayed as same symbols for each of the two levels of standpipe height. The repeatability is reflected by the spread in the shear for these duplicates.

Table: 17: Solids Circulation and Standpipe Height Test Independent Variables

\begin{tabular}{|c|c|c|c|}
\hline$\underline{\text { Run }}$ & $\begin{array}{c}\text { Standpipe Height } \\
\mathbf{f t}\end{array}$ & $\begin{array}{c}\text { Solids Circulation } \\
\mathbf{l b / h r}\end{array}$ & $\begin{array}{c}-\Delta \mathbf{P}_{\mathbf{g}} / \mathbf{L} \\
\mathbf{l b} / \mathbf{f t}^{\mathbf{3}}\end{array}$ \\
\hline 1 & 27 & 2,000 & 2.8 \\
\hline 2 & 27 & 4,000 & 2.8 \\
\hline 3 & 31 & 2,000 & 2.8 \\
\hline 4 & 31 & 4,000 & 2.8 \\
\hline 5 & 27 & 2,000 & 2.8 \\
\hline 6 & 27 & 4,000 & 2.8 \\
\hline 7 & 31 & 2,000 & 2.8 \\
\hline 8 & 31 & 4,000 & 2.8 \\
\hline
\end{tabular}


Table 18: Solids Circulation and Standpipe Height Results, Cork

\begin{tabular}{|c|c|c|c|c|c|}
\hline Run & $\begin{array}{c}\text { Standpipe } \\
\text { Height } \\
\underline{f t}\end{array}$ & $\begin{array}{c}\text { Solids } \\
\text { Circulation } \\
\underline{\text { lb/hr }}\end{array}$ & $\begin{array}{c}-\Delta \mathbf{P}_{\mathrm{g} / \mathbf{L}} \\
\underline{\mathbf{b} / \mathbf{f t}^{3}}\end{array}$ & $\begin{array}{c}-2 \tau_{\mathbf{s w}} / \mathbf{R} \\
\underline{\mathbf{l b} / \mathbf{f t}^{3}}\end{array}$ & $\begin{array}{c}-\Delta \mathbf{P}_{s} / \mathbf{L} \\
\underline{\mathbf{l b} / \mathbf{f t}^{3}}\end{array}$ \\
\hline 1 & 27 & 2,051 & $\overline{2.78}$ & $\overline{0.605}$ & $\overline{2.111}$ \\
\hline 2 & 27.5 & 3,799 & 2.78 & 0.666 & 2.053 \\
\hline 3 & 31 & 1,873 & 2.75 & 0.575 & 2.179 \\
\hline 4 & 31.4 & 3,762 & 2.73 & 0.531 & 2.241 \\
\hline 5 & 27.5 & 1,857 & 2.75 & 0.738 & 2.013 \\
\hline 6 & 27.5 & 3,703 & 2.76 & 0.649 & 2.092 \\
\hline 7 & 31.4 & 1,907 & 2.87 & 0.711 & 1.915 \\
\hline 8 & 31.2 & 3,757 & 2.71 & 0.682 & 2.109 \\
\hline
\end{tabular}

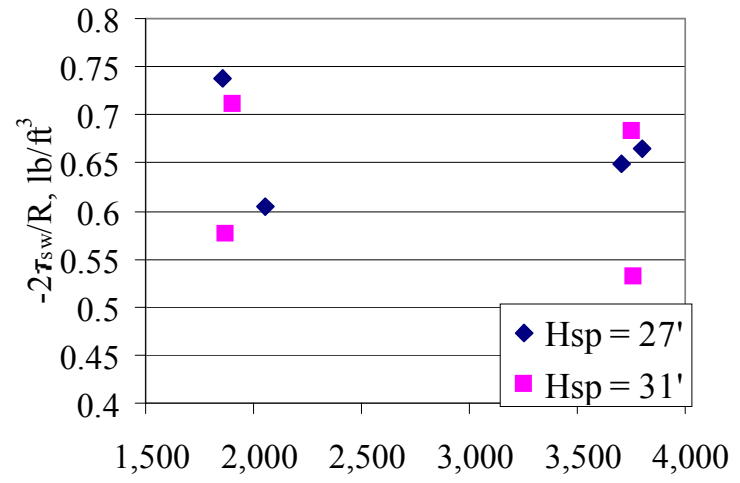

Solids Circulation, $\mathrm{lb} / \mathrm{hr}$

Figure 55: The Effect of Solids Circulation and Standpipe Height on the Shear Stress Component for a Packed Bed Regime, Cork

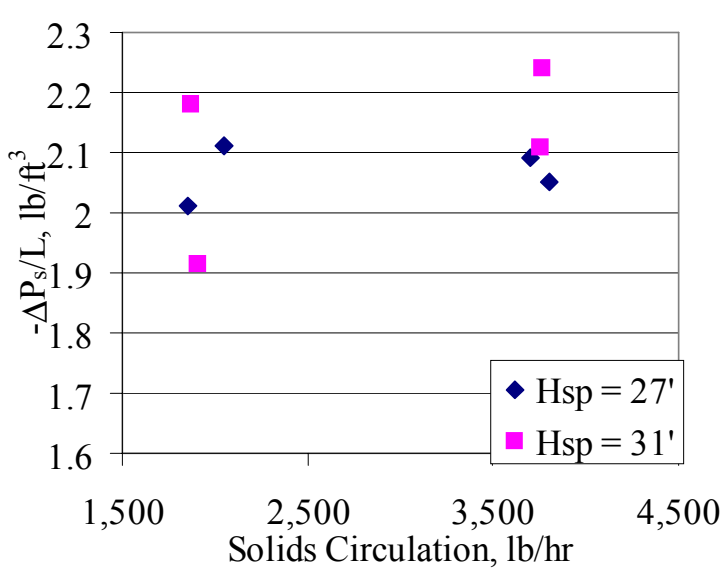

Figure 56: The Effect of Solids Circulation and Standpipe Height on the Solids Pressure Component for a Packed Bed Regime, Cork

Looking at Figures 55 and 56, neither solids circulation or standpipe height had an effect on the shear stress and solids pressure components of the momentum balance, at least within the ranges of the tested circulation rates and standpipe heights. The resulting ANOVA tables (Tables 19 and 20) for the shear stress component and the solids pressure component, which statistically confirm the lack of any significance for these factors. Notice that standpipe height and solids circulation are denoted as HSP and MS, respectively. 
Table 19: ANOVA Results for the Shear Stress Component of the Solids Circulation and Standpipe Height Test, Cork

Tests of Between-Subjects Effects

Dependent Variable: Shear Stress Component

\begin{tabular}{|c|c|c|c|c|c|}
\hline Source & $\begin{array}{c}\text { Type I } \\
\text { Sum of } \\
\text { Squares }\end{array}$ & df & $\begin{array}{c}\text { Mean } \\
\text { Square }\end{array}$ & $\mathrm{F}$ & Sig. \\
\hline $\begin{array}{l}\text { Corrected } \\
\text { Model }\end{array}$ & $4.624 \mathrm{E}-03^{a}$ & 3 & 1.541E-03 & .209 & .886 \\
\hline Intercept & 3.323 & 1 & 3.323 & 449.634 & .000 \\
\hline HSP & 3.096E-03 & 1 & 3.096E-03 & .419 & .553 \\
\hline MS & 1.281E-03 & 1 & $1.281 \mathrm{E}-03$ & .173 & 699 \\
\hline $\mathrm{HSP} * \mathrm{MS}$ & 2.470E-04 & 1 & 2.470E-04 & .033 & .864 \\
\hline Error & 2.957E-02 & 4 & 7.391E-03 & & \\
\hline Total & 3.358 & 8 & & & \\
\hline $\begin{array}{l}\text { Corrected } \\
\text { Total }\end{array}$ & 3.419E-02 & 7 & & & \\
\hline
\end{tabular}

a. $\mathrm{R}$ Squared $=.135$ (Adjusted $\mathrm{R}$ Squared $=-.513$ )

Table 20: ANOVA Results for the Solids Pressure Component of the Solids Circulation and Standpipe Height Test, Cork

Tests of Between-Subjects Effects

\begin{tabular}{|c|c|c|c|c|c|}
\hline Source & $\begin{array}{c}\text { Type I } \\
\text { Sum of } \\
\text { Squares } \\
\end{array}$ & df & $\begin{array}{c}\text { Mean } \\
\text { Square }\end{array}$ & $\mathrm{F}$ & Sig. \\
\hline $\begin{array}{l}\text { Corrected } \\
\text { Model }\end{array}$ & $2.036 \mathrm{E}-02^{a}$ & 3 & 6.787E-03 & .553 & .673 \\
\hline Intercept & 34.913 & 1 & 34.913 & 2842.483 & .000 \\
\hline HSP & 3.865E-03 & 1 & $3.865 \mathrm{E}-03$ & .315 & .605 \\
\hline MS & 9.597E-03 & 1 & 9.597E-03 & .781 & .427 \\
\hline $\mathrm{HSP}{ }^{*} \mathrm{MS}$ & 6.899E-03 & 1 & 6.899E-03 & .562 & .495 \\
\hline Error & 4.913E-02 & 4 & $1.228 \mathrm{E}-02$ & & \\
\hline Total & 34.983 & 8 & & & \\
\hline $\begin{array}{l}\text { Corrected } \\
\text { Total }\end{array}$ & 6.949E-02 & 7 & & & \\
\hline
\end{tabular}

a. $\mathrm{R}$ Squared $=.293$ (Adjusted $\mathrm{R}$ Squared $=-.237$ )

Section 3.5c discussed the information given in the ANOVA table in detail. From

Tables 19 and 20 neither of the independent variables have a significant effect on either of the dependent variables. 
5.1c The Effect of Solids Circulation Rate and Gas Pressure Drop $\left(-\Delta P_{g} / L\right)$ on a Packed Regime

In this section the test to determine the effect of solids circulation rate and gas pressure drop on the shear stress component is discussed. The experimental matrix listed in Table 21 was a randomized $2^{2}$ factorial test fully duplicated.

Table 21: Solids Circulation and Gas Pressure Drop $\left(-\Delta \mathbf{P}_{\mathrm{g}} / \mathbf{L}\right)$ Test Independent Variables

\begin{tabular}{|c|c|c|c|}
\hline$\underline{\text { Run }}$ & $\begin{array}{c}\text { Solids Circulation } \\
\mathbf{l b} / \mathbf{h r}\end{array}$ & $\begin{array}{c}-\Delta \mathbf{P}_{\mathbf{g}} / \mathbf{L} \\
\mathbf{l b} / \mathbf{f t}^{3}\end{array}$ & $\begin{array}{c}\text { Standpipe Height } \\
\mathbf{f t}\end{array}$ \\
\hline 1 & 2,000 & 2.3 & 29 \\
\hline 2 & 2,000 & 3.3 & 29 \\
\hline 3 & 4,000 & 2.3 & 29 \\
\hline 4 & 4,000 & 3.3 & 29 \\
\hline 5 & 2,000 & 2.3 & 29 \\
\hline 6 & 2,000 & 3.3 & 29 \\
\hline 7 & 4,000 & 2.3 & 29 \\
\hline 8 & 4,000 & 3.3 & 29 \\
\hline
\end{tabular}

The results and the response variables are listed in Table 22 and summarized in

Figures 57 and 58. The shear stress was measured at 13.5 ' by the wall shear probe

Table 22: Solids Circulation and Gas Pressure Drop $\left(-\Delta \mathbf{P}_{\mathrm{g}} / \mathbf{L}\right)$ Test Results, Cork

\begin{tabular}{|c|c|c|c|c|c|}
\hline$\underline{\text { Run }}$ & $\begin{array}{c}\text { Solids } \\
\text { Circulation } \\
\underline{\text { lb/hr }}\end{array}$ & $\begin{array}{c}-\Delta \mathbf{P}_{\mathrm{g} / \mathbf{L}} \\
\mathbf{l \mathbf { l } / \mathbf { f t } ^ { 3 }}\end{array}$ & $\begin{array}{c}\text { Standpipe } \\
\text { Height } \\
\underline{f t}\end{array}$ & $\begin{array}{c}-2 \tau_{\mathbf{s w}} / \mathbf{R} \\
\underline{\mathbf{l} / \mathbf{f t}^{3}}\end{array}$ & $\begin{array}{r}-\Delta \mathbf{P}_{s} / \mathbf{L} \\
\underline{\mathbf{l b} / \mathbf{f t}^{3}}\end{array}$ \\
\hline 1 & 1,904 & $\overline{2.349}$ & 29.3 & $\overline{0.148}$ & $\overline{2.919}$ \\
\hline 2 & 1,944 & 3.283 & 28.8 & 0.066 & 2.376 \\
\hline 3 & 4,101 & 2.372 & 28.7 & 0.092 & 3.189 \\
\hline 4 & 4,012 & 3.259 & 29.3 & 0.076 & 2.378 \\
\hline 5 & 2,040 & 2.295 & 29.3 & 0.100 & 3.225 \\
\hline 6 & 1,852 & 3.437 & 29 & 0.079 & 2.162 \\
\hline 7 & 4,193 & 2.252 & 29.1 & 0.121 & 3.144 \\
\hline 8 & 3,695 & 3.168 & 29 & 0.091 & 2.374 \\
\hline
\end{tabular}




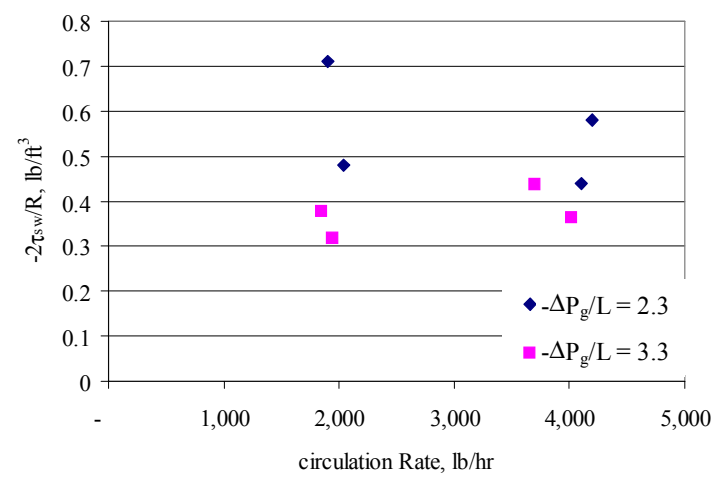

Figure 57: The Effect of Solids Circulation and Gas Pressure Drop ($\left.\Delta \mathbf{P}_{\mathrm{g}} / \mathrm{L}\right)$ on the Shear Stress Component for a Packed Regime, Cork

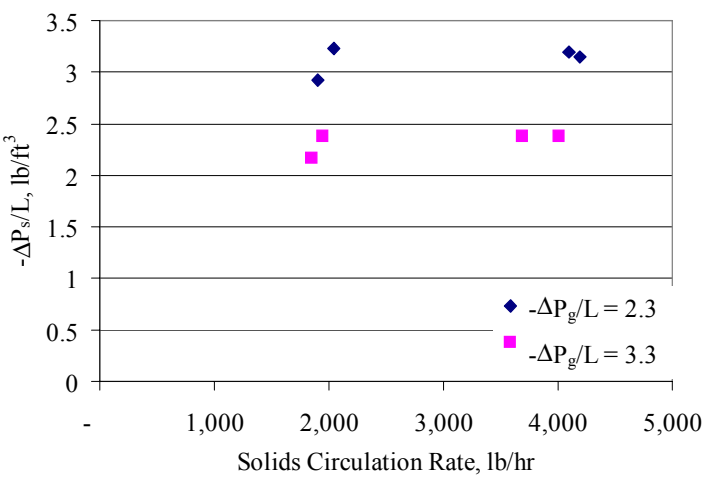

Figure 58: The Effect of Solids Circulation and Gas Pressure Drop ($\left.\Delta \mathbf{P}_{\mathrm{g}} / \mathbf{L}\right)$ on the Solids Pressure Component for a Packed Regime, Cork

In Figure 57 the shear stress component appeared to be higher with lower gas pressure drop $\left(-\Delta \mathrm{P}_{\mathrm{g}} / \mathrm{L}\right)$. In Figure 58 the solids pressure component appeared to increase with lower gas pressure drop $\left(-\Delta \mathrm{P}_{\mathrm{g}} / \mathrm{L}\right)$. In general the shear stress component measured were very small compared with the bulk density of cork, $6.6 \mathrm{lb} / \mathrm{ft}^{3}$.

A type I sum of square analyses was applied to the two independent variables listed in Table 22. Table 23 describes the results for the shear stress component of the momentum balance. Notice that gas pressure drop $\left(-\Delta \mathrm{P}_{\mathrm{g}} / \mathrm{L}\right)$ is denoted as DPGDL and solids circulation rate is denoted as MS.

Table 23: ANOVA Results for the Shear Stress Component of the Solids Circulation and Gas Pressure Drop $\left(-\Delta \mathbf{P}_{\mathrm{g}} / \mathbf{L}\right)$ Test, Cork

Tests of Between-Subjects Effects

Dependent Variable: Shear Stress Component

\begin{tabular}{|c|c|c|c|c|c|}
\hline Source & $\begin{array}{l}\text { Type I } \\
\text { Sum of } \\
\text { Squares }\end{array}$ & df & $\begin{array}{l}\text { Mean } \\
\text { Square }\end{array}$ & $\mathrm{F}$ & Sig. \\
\hline $\begin{array}{l}\text { Corrected } \\
\text { Model }\end{array}$ & $3.212 \mathrm{E}-03^{a}$ & 3 & 1.071E-03 & 2.433 & .205 \\
\hline Intercept & 7.441E-02 & 1 & 7.441E-02 & 169.077 & .000 \\
\hline MS & 2.476E-05 & 1 & 2.476E-05 & .056 & .824 \\
\hline DPGDL & 2.786E-03 & 1 & 2.786E-03 & 6.331 & .066 \\
\hline $\begin{array}{l}\text { MS * } \\
\text { DPGDL }\end{array}$ & 4.009E-04 & 1 & 4.009E-04 & .911 & .394 \\
\hline Error & 1.760E-03 & 4 & 4.401E-04 & & \\
\hline Total & 7.938E-02 & 8 & & & \\
\hline $\begin{array}{l}\text { Corrected } \\
\text { Total }\end{array}$ & 4.972E-03 & 7 & & & \\
\hline
\end{tabular}

a. R Squared $=.646($ Adjusted $R$ Squared $=.380)$ 
Section 3.5c discussed the information given in the ANOVA table in detail. From Table 23, the significance level for gas pressure drop $\left(-\Delta \mathrm{P}_{\mathrm{g}} / \mathrm{L}\right)$ on the shear stress component is within $90 \%$ confidence of being significant.

\section{Table 24: ANOVA Results for Solids Pressure Drop $\left(-\Delta \mathbf{P}_{s} / L\right)$ of the Solids} Circulation and Gas Pressure Drop $\left(-\Delta \mathbf{P}_{\mathrm{g}} / \mathrm{L}\right)$ Test, Cork

Tests of Between-Subjects Effects

Dependent Variable: solids pressure drop per unit length

\begin{tabular}{|c|c|c|c|c|c|}
\hline Source & $\begin{array}{c}\text { Type I } \\
\text { Sum of } \\
\text { Squares }\end{array}$ & $\mathrm{df}$ & $\begin{array}{l}\text { Mean } \\
\text { Square }\end{array}$ & $\mathrm{F}$ & Sig. \\
\hline $\begin{array}{l}\text { Corrected } \\
\text { Model }\end{array}$ & $1.290^{a}$ & 3 & .430 & 24.316 & .005 \\
\hline Intercept & 59.225 & 1 & 59.225 & 3349.065 & .000 \\
\hline MS & 2.030E-02 & 1 & $2.030 \mathrm{E}-02$ & 1.148 & .344 \\
\hline DPGDL & 1.270 & 1 & 1.270 & 71.794 & .001 \\
\hline $\begin{array}{l}\text { MS * } \\
\text { DPGDL }\end{array}$ & 7.813E-05 & 1 & 7.813E-05 & .004 & .950 \\
\hline Error & 7.074E-02 & 4 & 1.768E-02 & & \\
\hline Total & 60.586 & 8 & & & \\
\hline $\begin{array}{l}\text { Corrected } \\
\text { Total }\end{array}$ & 1.361 & 7 & & & \\
\hline
\end{tabular}

a. $\mathrm{R}$ Squared $=.948($ Adjusted $\mathrm{R}$ Squared $=.909)$

In Table 24, gas pressure drop $\left(-\Delta \mathrm{P}_{\mathrm{g}} / \mathrm{L}\right)$ has a significant effect on solids pressure $\operatorname{drop}\left(-\Delta \mathrm{P}_{\mathrm{S}} / \mathrm{L}\right)$. This is consistent, since solids pressure drop $\left(-\Delta \mathrm{P}_{\mathrm{s}} / \mathrm{L}\right)$ is calculated directly from gas pressure drop $\left(-\Delta \mathrm{P}_{\mathrm{g}} / \mathrm{L}\right)$ assuming a constant bulk density and using measured shear stress values, which are very small in comparison to the other three forces.

The experiment outlined in Table 21 was repeated using higher circulation rates and an adjusted gas pressure drop per unit length. Solids volume fraction measurements were obtained for this experiment. The experimental matrix outlined in Table 25 is a randomized $2^{2}$ factorial matrix fully duplicated. 
Table 25: Solids Circulation and Gas Pressure Drop $\left(-\Delta \mathbf{P}_{\mathrm{g}} / \mathbf{L}\right)$ Test, Higher Circulation Rates, Independent Variables

\begin{tabular}{|c|c|c|c|}
\hline$\underline{\text { Run }}$ & $\begin{array}{c}\text { Solids Circulation } \\
\mathbf{I b / h \mathbf { h }}\end{array}$ & $\begin{array}{c}-\Delta \mathbf{P}_{\mathbf{g}} / \mathbf{L} \\
\mathbf{\mathbf { b }} / \mathbf{f t}^{\mathbf{3}}\end{array}$ & $\begin{array}{c}\text { Standpipe Height } \\
\mathbf{f t}\end{array}$ \\
\hline 1 & 3,000 & 2.4 & 29 \\
\hline 2 & 3,000 & 3.3 & 29 \\
\hline 3 & 6,000 & 2.4 & 29 \\
\hline 4 & 6,000 & 3.3 & 29 \\
\hline 5 & 3,000 & 2.4 & 29 \\
\hline 6 & 3,000 & 3.3 & 29 \\
\hline 7 & 6,000 & 2.4 & 29 \\
\hline 8 & 6,000 & 3.3 & \\
\hline
\end{tabular}

The results and the response variables are given in Table 26 and summarized in Figures 59 and 61 . The last column, $\varepsilon_{\mathrm{s}}$, corresponds to the measured solids volume fraction at the wall, using the probe described in Chapter 3. The shear stress was measured at $13.5^{\prime}$ by the wall shear probe.

Table 26: Solids Circulation and Gas Pressure Drop $\left(-\Delta \mathbf{P}_{\mathrm{g}} / \mathrm{L}\right)$ Test Results, Higher Circulation Rates, Cork

\begin{tabular}{|c|c|c|c|c|c|c|}
\hline$\underline{\text { Run }}$ & $\begin{array}{c}\text { Solids } \\
\text { Circulation } \\
\text { lb/hr } \\
\end{array}$ & $\begin{array}{c}-\Delta \mathbf{P}_{\mathbf{g}} / \mathbf{L} \\
\underline{\mathbf{l b} / \mathbf{f t}^{\mathbf{3}}}\end{array}$ & $\begin{array}{c}\text { Standpipe } \\
\text { Height } \\
\text { ft }\end{array}$ & $\begin{array}{c}-2 \tau_{\mathbf{s w}} / \mathbf{R} \\
\underline{\mathbf{l b} / \mathbf{f t}^{3}}\end{array}$ & $\begin{array}{c}-\Delta \mathbf{P}_{\mathbf{s}} / \mathbf{L} \\
\underline{\mathbf{l b} / \mathbf{f} \mathbf{t}^{\mathbf{3}}}\end{array}$ & $\varepsilon_{\mathrm{s}}$ \\
\hline 1 & 3,047 & 2.374 & 29.2 & 0.495 & 3.131 & 0.342 \\
\hline 2 & 2,955 & 3.253 & 28.7 & 0.494 & 2.254 & 0.347 \\
\hline 3 & 5,862 & 2.496 & 29 & 0.473 & 3.032 & 0.344 \\
\hline 4 & 5,918 & 3.246 & 28.7 & 0.402 & 2.352 & 0.363 \\
\hline 5 & 3,047 & 2.400 & 28.8 & 0.513 & 3.087 & 0.352 \\
\hline 6 & 3,016 & 3.202 & 29.3 & 0.467 & 2.330 & 0.333 \\
\hline 7 & 5,920 & 2.436 & 28.8 & 0.586 & 2.978 & 0.358 \\
\hline 8 & 5,949 & 3.289 & 29 & 0.398 & 2.312 & 0.371 \\
\hline
\end{tabular}




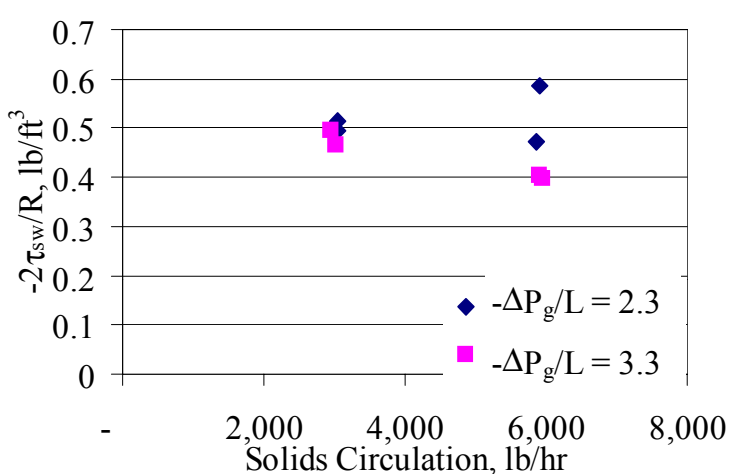

Figure 59: The Effect of Solids Circulation and Gas Pressure Drop ($\left.\Delta \mathbf{P}_{\mathbf{g}} / \mathbf{L}\right)$ (at Higher Circulation Rates) on the Shear Stress Component

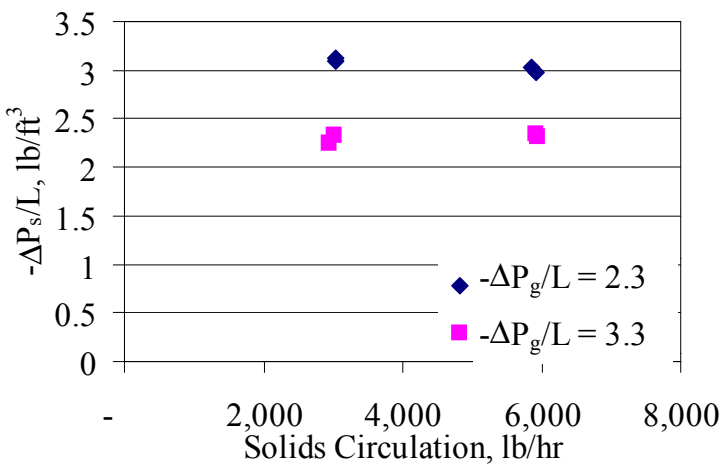

Figure 60: The Effect of Solids Circulation and Gas Pressure Drop ($\left.\Delta \mathbf{P}_{\mathrm{g}} / \mathrm{L}\right)$ (at Higher Circulation Rates) on the Solids Pressure Component

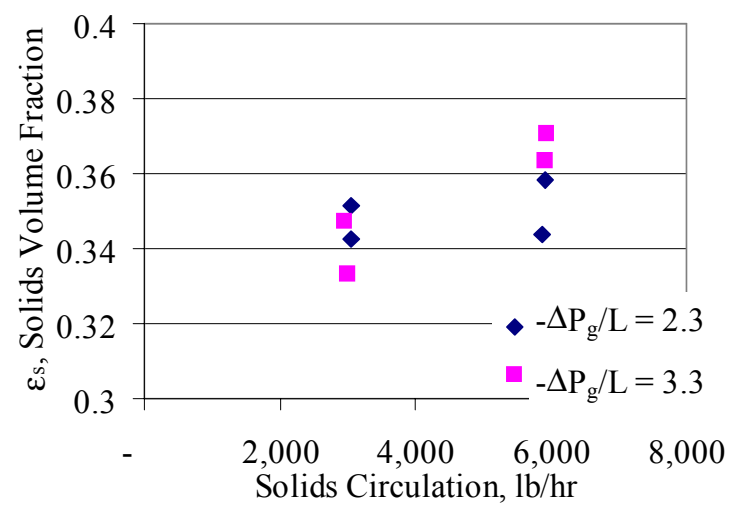

Figure 61: The Effect of Solids Circulation and Gas Pressure Drop (- $\left.\Delta \mathbf{P}_{g} / L\right)(a t$ Higher Circulation Rates) on the Wall Solids Volume Fraction

In Figure 60 , the solids pressure drop $\left(-\Delta \mathrm{P}_{\mathrm{s}} / \mathrm{L}\right)$ increased with decreasing gas phase pressure, which is consistent with what was seen in the previous test. However, in Figure 57 the shear stress component appeared to increase with decreasing gas pressure drop $\left(-\Delta \mathrm{P}_{\mathrm{g}} / \mathrm{L}\right)$ at high circulation rates. Furthermore, the solids volume fraction measurements in Figure 61 appear to increase with increasing gas pressure drop $\left(-\Delta \mathrm{P}_{\mathrm{g}} / \mathrm{L}\right)$ at higher circulation rates. As will become evident in Section 5.2d, absolute solids volume fraction measurements are not yet fully trusted due to the calibration of the instrument. Relative solids volume fraction measurements were not so much an issue.

A type I sum of square analyses was applied to the three independent variables listed in Table 26. Table 27 describes the results for the shear stress component of the 
momentum balance. Notice that gas pressure drop $\left(-\Delta \mathrm{P}_{\mathrm{g}} / \mathrm{L}\right)$ is denoted as DPGDL and solids circulation rate is denoted as MS.

Table 27: ANOVA Results for the Shear Stress Component of the Solids Circulation and Gas Pressure Drop $\left(-\Delta \mathbf{P}_{\mathrm{g}} / \mathbf{L}\right)$ Test, Higher Circulation Rates, Cork

Tests of Between-Subjects Effects

Dependent Variable: shear stress component

\begin{tabular}{|c|c|c|c|c|c|}
\hline Source & $\begin{array}{c}\text { Type I } \\
\text { Sum of } \\
\text { Squares }\end{array}$ & df & $\begin{array}{c}\text { Mean } \\
\text { Square }\end{array}$ & $F$ & Sig. \\
\hline $\begin{array}{l}\text { Corrected } \\
\text { Model }\end{array}$ & $1.870 \mathrm{E}-02^{\mathrm{a}}$ & 3 & $6.233 \mathrm{E}-03$ & 3.606 & .124 \\
\hline Intercept & 1.831 & 1 & 1.831 & 1059.403 & .000 \\
\hline MS & 1.525E-03 & 1 & $1.525 \mathrm{E}-03$ & .882 & .401 \\
\hline DPGDL & 1.167E-02 & 1 & 1.167E-02 & 6.751 & .060 \\
\hline $\begin{array}{l}\text { MS * } \\
\text { DPGDL }\end{array}$ & 5.505E-03 & 1 & 5.505E-03 & 3.185 & .149 \\
\hline Error & 6.914E-03 & 4 & $1.728 \mathrm{E}-03$ & & \\
\hline Total & 1.857 & 8 & & & \\
\hline $\begin{array}{l}\text { Corrected } \\
\text { Total }\end{array}$ & $2.561 \mathrm{E}-02$ & 7 & & & \\
\hline
\end{tabular}

a. $\mathrm{R}$ Squared $=.730($ Adjusted $\mathrm{R}$ Squared $=.528)$

Section 3.5c discussed the information given in the ANOVA table in detail. From Table 27, the significance level for gas pressure drop $\left(-\Delta \mathrm{P}_{\mathrm{g}} / \mathrm{L}\right)$ is within $90 \%$ confidence of being significant.

Table 28: ANOVA Results for the Solids Pressure Component of the Solids Circulation and Gas Pressure Drop $\left(-\Delta \mathbf{P}_{\mathrm{g}} / \mathrm{L}\right)$ Test, Higher Circulation rates, Cork

Tests of Between-Subjects Effects

\begin{tabular}{|c|c|c|c|c|c|}
\hline Source & $\begin{array}{l}\text { Type I } \\
\text { Sum of } \\
\text { Squares }\end{array}$ & df & $\begin{array}{l}\text { Mean } \\
\text { Square }\end{array}$ & $\mathrm{F}$ & Sig. \\
\hline $\begin{array}{l}\text { Corrected } \\
\text { Model }\end{array}$ & $1.122^{a}$ & 3 & .374 & 243.456 & .000 \\
\hline Intercept & 57.653 & 1 & 57.653 & 37525.903 & .000 \\
\hline MS & 2.060E-03 & 1 & $2.060 \mathrm{E}-03$ & 1.341 & .311 \\
\hline DPGDL & 1.110 & 1 & 1.110 & 722.276 & .000 \\
\hline $\begin{array}{l}\text { MS * } \\
\text { DPGDL }\end{array}$ & 1.037E-02 & 1 & 1.037E-02 & 6.751 & .060 \\
\hline Error & 6.145E-03 & 4 & 1.536E-03 & & \\
\hline Total & 58.781 & 8 & & & \\
\hline $\begin{array}{l}\text { Corrected } \\
\text { Total }\end{array}$ & 1.128 & 7 & & & \\
\hline
\end{tabular}

a. $\mathrm{R}$ Squared $=.995$ (Adjusted $\mathrm{R}$ Squared $=.990)$ 
Table 29: ANOVA Results for the Solids Volume Fraction of the Solids Circulation and Gas Pressure Drop (- $\left.\Delta \mathbf{P}_{\mathrm{g}} / \mathrm{L}\right)$ Test, Higher Circulation rates, Cork

Tests of Between-Subjects Effects

\begin{tabular}{|c|c|c|c|c|c|}
\hline Source & $\begin{array}{c}\text { Type I } \\
\text { Sum of } \\
\text { Squares }\end{array}$ & df & $\begin{array}{c}\text { Mean } \\
\text { Square } \\
\end{array}$ & $\mathrm{F}$ & Sig. \\
\hline $\begin{array}{l}\text { Corrected } \\
\text { Model }\end{array}$ & $7.815 \mathrm{E}-04^{a}$ & 3 & 2.605E-04 & 3.817 & .114 \\
\hline Intercept & .987 & 1 & .987 & 14463.969 & .000 \\
\hline MS & 4.777E-04 & 1 & 4.777E-04 & 7.000 & .057 \\
\hline DPGDL & 4.301E-05 & 1 & 4.301E-05 & .630 & .472 \\
\hline $\begin{array}{l}\text { MS * } \\
\text { DPGDL }\end{array}$ & 2.608E-04 & 1 & $2.608 \mathrm{E}-04$ & 3.821 & .122 \\
\hline Error & 2.730E-04 & 4 & $6.825 \mathrm{E}-05$ & & \\
\hline Total & .988 & 8 & & & \\
\hline $\begin{array}{l}\text { Corrected } \\
\text { Total }\end{array}$ & $1.055 \mathrm{E}-03$ & 7 & & & \\
\hline
\end{tabular}

a. $\mathrm{R}$ Squared $=.741$ (Adjusted $\mathrm{R}$ Squared $=.547$ )

In Table 28, the significance of gas pressure drop $\left(-\Delta \mathrm{P}_{\mathrm{g}} / \mathrm{L}\right)$ on solids pressure drop $\left(-\Delta \mathrm{P}_{\mathrm{g}} / \mathrm{L}\right)$ is apparent, which is consistent with previous results. In Table 29 , the solids circulation is very close to being significant for solids volume fraction at a $95 \%$ level. In Figure 61, the solids volume fraction increased with increasing solids circulation, though this was more evident for the higher level of gas pressure drop $\left(-\Delta \mathrm{P}_{\mathrm{g}} / \mathrm{L}\right)$. Variations in solids volume fraction were quite small. Because this is a local measurement of solids volume fraction, this may provide an indication that the solids are beginning to stick to the wall.

\subsection{Qualitative Study}

The qualitative tests discussed in this section in general are transient ramps. These ramps allowed us to compare material-material differences. Hysteresis and compaction of the bed were apparent in these studies. Several of the ramps were for a stationary condition (bubbling bed). In a stationary bed the fluidization regime was clearly defined. Therefore, fluidization regimes as well as the collective effect of gas pressure drop and solids volume fraction were studied. 


\section{2a Filling and draining Tests}

A series of tests in which the standpipe was filled and drained were run to determine the effects of bed height on shear stress. These tests were conducted under packed/moving, unaerated conditions. Bed heights up to 40 " above the shear vane were investigated, as well as heights below the vane. Along the length of the vane, a dependence on height was expected, since shear stress is force per unit area and the area is not constant as the bed either fills or drains past the vane. Further, heights that are below the vane do not register any force at all.

A list of relevant variables and their settings are shown in Table 30. A shear vane at $7^{\prime}$ measured the shear stress in this study.

Table 30: Filling and Draining Test Variables, $230 \mu \mathrm{m}$ Coke

\begin{tabular}{|c|c|c|}
\hline $\begin{array}{c}\text { Independent } \\
\text { Variables }\end{array}$ & $\begin{array}{l}\text { Dependent } \\
\text { Variables }\end{array}$ & $\begin{array}{c}\text { Controlled } \\
\text { Variables }\end{array}$ \\
\hline $\begin{array}{l}\text { Height of standpipe } \\
\text { (37" to } 108 \text { ") }\end{array}$ & $\begin{array}{c}\text { Shear stress }-2 \tau_{\mathrm{sw}} / \mathrm{R} \\
1.1 \text { to } 11.7 \mathrm{lb} / \mathrm{ft}^{3}\end{array}$ & $\begin{array}{l}\text { Standpipe Aeration } \\
0 \mathrm{scfh}\end{array}$ \\
\hline $\begin{array}{l}\text { Butterfly valve in standpipe } \\
\text { Closed Drain/ Opened Fill }\end{array}$ & $\begin{array}{l}-\Delta \mathrm{P}_{\mathrm{g}} \text { across } \mathrm{SV} \\
-0.07 \text { To } 0.35 \mathrm{psi}\end{array}$ & $\begin{array}{l}\text { Riser Aeration } \\
80,000 \mathrm{scfh}\end{array}$ \\
\hline $\begin{array}{c}\text { Loopseal Aeration } \\
\text { 2250scfh Drain/ } 0 \text { scfh Fill }\end{array}$ & $\begin{array}{c}\varepsilon \\
\text { (not measured) }\end{array}$ & $\begin{array}{l}\text { Aeration at } 15 \\
0 \mathrm{scfh}\end{array}$ \\
\hline $\begin{array}{c}\text { Aeration at } 7.5 \\
40 \mathrm{scfh} \text { Drain/0 scfh fill }\end{array}$ & & $\begin{array}{l}\text { The total inventory was } \\
\text { approximately } 750 \mathrm{lb}\end{array}$ \\
\hline
\end{tabular}

The test started with the standpipe filled. To drain the bed past the vane, aeration in the loopseal was set at 2,250 scfh and staged aeration at $7.5^{\prime}$ was set at 40 scfh. This staged aeration is directly above the shear vane. The butterfly valve at a height of $13.5^{\prime}$ in the standpipe was placed in the closed position to keep the bed from circulating back. The aeration allowed the bed to drain into the riser and return above the butterfly valve. Bed height measurements were taken as the bed drained past the vane. Once the bed was drained, all aeration was shut off to prohibit the bed from moving during the fill. To conduct the filling test the butterfly valve was cracked opened and the bed filled around the vane while height measurements were taken.

Shear stress versus height has been plotted in Figure 62. Keep in mind that the area of the vane is $1 \mathrm{ft}^{2}$. Therefore, a plot of force measured in $\mathrm{lb}$ versus height would give the exact same trends and magnitudes as a plot of shear stress in $1 \mathrm{~b} / \mathrm{ft}^{2}$ versus height. 
The 1-ft2 area was used for all of the shear stress calculations including the cases when the vane was not completely immersed in the bed.

The two bold, vertical lines indicate the location of the leading and trailing edges of the shear vane. The leading and trailing edges are at 68 " and 44 " respectively. As expected the shear stress increases as the length of the vane covered by the particles increases. This relationship is almost linear for the filling situation.

At the same heights the drain values are lower in magnitude then the fill values. This could be a result of the aeration that was used at $7.5^{\prime}$ and the loopseal aeration. No aeration other than riser flow was used during the fill. The aeration during the drain may have resulted in a higher void fraction and possibly another fluidization state. Unfortunately, void fraction was not measured. Due to the split of aeration at the bottom of the standpipe gas velocities and fluidization states are unknown. To give an idea of the difference made by the aeration, the pressure drop across the section of interest was plotted against the different heights during filling and draining (Figure 63). Notice that the pressure drop in the drain case was larger and in the opposite direction compared to the fill case. This indicates that the gas was moving down relative to the solids for the drain case and up for the fill case. Keep in mind that gas pressure drop $\left(-\Delta \mathrm{P}_{\mathrm{g}} / \mathrm{L}\right)$ was the only significant variable for the shear stress component when operating in a packed or transitionally packed regime in Section 5.1c.

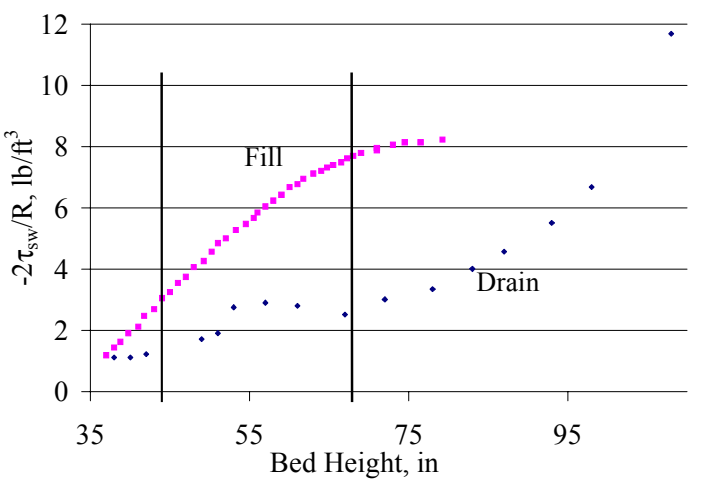

Figure 62: Shear Stress Versus Bed Height, Filling and Draining Tests, 230 $\mu \mathrm{m}$ Coke

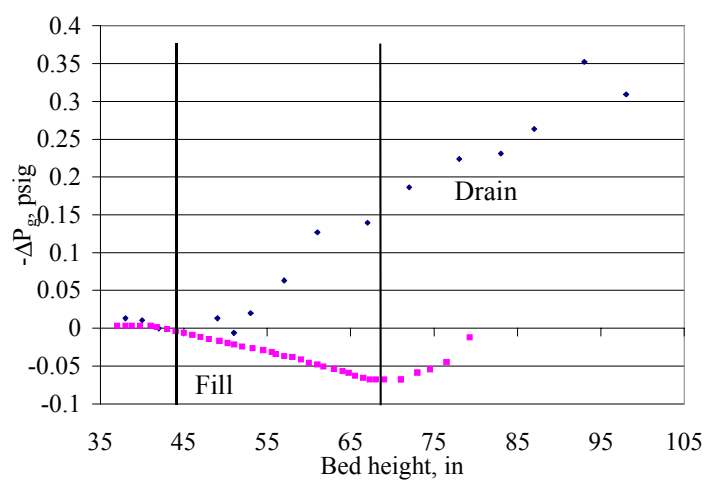

Figure 63: Gas Phase Pressure drop versus Bed Height, Draining and Filling Tests, $230 \mu \mathrm{m}$ Coke

The draining bed measurements are spaced farther apart, because the speed at which the bed was drained was faster than the speed at which it was filled. This may also 
be an explanation for the differences between the two behaviors, because the solids velocities and gas velocities are very different between the two cases.

The shear stress values for the draining bed are constant once the bed height is below the trailing edge of the vane. This is expected since there are no particles acting along the length of the vane. It is also expected that this constant value should be close to zero. Any offset can be attributed to calibration or possibly gas shear.

In contrast to the case for the draining bed, the magnitude of the shear stress values increase linearly as the bed height increases for values of height below the trailing edge of the vane. This is due to particle shear past the vane during filling.

The steady state momentum balance was not applied here because these were not steady conditions. Also, parasitic drag was not considered in this analysis.

Although it was not a significant variable in section 5.1b, height appears to have an effect on shear vane measurements in this study especially along the length of the vane. However, more importantly the pressure drop in the control volume that holds the shear vane had a strong effect on the measurements. This pressure drop indicates changes in gas flow direction, and possible changes in the void fraction and fluidization state. See section 5.1c. Further, this pressure drop may have a larger impact on the shear stress than the variation in bed height.

\section{2b Stationary Bed Aeration Ramps, Coke, in the Standpipe}

To understand the effect of aeration alone on shear stress measurements, aeration ramps were performed. Due to the split of aeration at the bottom of the standpipe

fluidization states can only be presumed using the gas pressure drop $\left(-\Delta \mathrm{P}_{\mathrm{g}} / \mathrm{L}\right)$. If the gas pressure drop $\left(-\Delta \mathrm{P}_{\mathrm{g}} / \mathrm{L}\right)$ was constant and high (near the weight of the bed), the bed is assumed to be fluidized, otherwise it is packed.

A list of variables and settings used in these ramps is shown in Table 31. A shear vane at $7^{\prime}$ measured shear stress in this section. 
Table 31 Stationary Bed Aeration Ramp Variables, Riser Flow 10,000 scfh, $230 \mu \mathrm{m}$ Coke

\begin{tabular}{|c|c|c|}
\hline $\begin{array}{l}\text { Independent } \\
\text { Variables }\end{array}$ & $\begin{array}{l}\text { Dependent } \\
\text { Variables }\end{array}$ & $\begin{array}{l}\text { Controlled } \\
\text { Variables }\end{array}$ \\
\hline \multirow[t]{7}{*}{$\begin{array}{l}\text { Standpipe Aeration } \\
\text { (move air) } \\
0 \text { to } 400 \mathrm{scfh}\end{array}$} & $\begin{array}{c}\text { Shear stress }-2 * \tau_{\mathrm{sw}} / \mathrm{R} \\
23 \text { to }-1.5 \mathrm{lb} / \mathrm{ft}^{3}\end{array}$ & $\begin{array}{l}\text { Loopseal Aeration } \\
0 \mathrm{scfh}\end{array}$ \\
\hline & $\begin{array}{l}\Delta \mathrm{P}_{\mathrm{g}} / \mathrm{L} \\
19.2 \text { to } 54 \mathrm{lb} / \mathrm{ft}^{3}\end{array}$ & $\begin{array}{l}\text { Riser Aeration } \\
10,000 \mathrm{scfh}\end{array}$ \\
\hline & $\begin{array}{c}\varepsilon \\
\text { not measured }\end{array}$ & $\begin{array}{c}\text { Aeration at } 15 \\
0 \mathrm{scfh}\end{array}$ \\
\hline & $\begin{array}{c}-\Delta \mathrm{P}_{\mathrm{s}} / \mathrm{L} \\
16 \text { to }-5 \mathrm{lb} / \mathrm{ft}^{3}\end{array}$ & $\begin{array}{c}\text { Aeration at } 7.5^{\prime} \\
0 \mathrm{scfh}\end{array}$ \\
\hline & $\begin{array}{c}\mathrm{V}_{\mathrm{g}} \\
\text { (unknown) }\end{array}$ & $\begin{array}{l}\text { Aeration at the bottom of } \\
\text { the standpipe } \\
0 \mathrm{scfh}\end{array}$ \\
\hline & & $\begin{array}{l}\text { Aeration at the dipleg } \\
0 \mathrm{scfh}\end{array}$ \\
\hline & & $\begin{array}{c}\text { Height of standpipe } \\
8 \mathrm{ft}\end{array}$ \\
\hline
\end{tabular}

Before the ramp test was conducted, a riser flow of 10,000 scfh was established, and the loopseal aeration was increased to $1,200 \mathrm{scfh}$ to move solids from the standpipe into the riser. This resulted in standpipe and fluidized riser heights of 8' and 7', respectively. Next, the loopseal aeration was cut off to stop circulation. The standpipe aeration was increased at a rate of $20 \mathrm{scfh} / \mathrm{min}$ from essentially 0 to $400 \mathrm{scfh}$. Then the aeration was decreased at a rate of $20 \mathrm{scfh} / \mathrm{min}$ from 400 to $0 \mathrm{scfh}$. No circulation took place during the ramps.

In Figure 64 the shear stress component of the momentum balance $\left(-2 \tau_{\mathrm{sw}} / \mathrm{R}\right)$ is plotted versus standpipe aeration for both ramping up and ramping down. Take note that parasitic drag was not considered since the bed was stationary. The discontinuities in the up ramp can be explained by the vane slipping through the bed. In other words on the ramp up the vane was under tension. Once the bed had relaxed enough, the shear decreased, and the vane slipped through the bed. There are no discontinuities in the down ramp since the bed is compacting around and pulling the vane down. Notice the sharp shift in shear stress from 10 to $-1.2 \mathrm{lb} / \mathrm{ft}^{3}$ between aeration rates of 270 to $315 \mathrm{scfh}$. This shift could be due to fluidization of the section in which the vane is immersed. This 
aeration rate corresponds to velocities of 1.4 and $1.6 \mathrm{ft} / \mathrm{sec}$, which is considerably higher than the measured minimum fluidization velocity of $0.07 \mathrm{ft} / \mathrm{sec}$. After this point the shear stress actually goes negative. The weight of the vane was lifted due to buoyancy. The maximum positive value measured was $1.59 \mathrm{lb} / \mathrm{ft}^{3}$.

In Figure 65 the components of the momentum balance are plotted against aeration air. The gas pressure $\operatorname{drop}\left(-\Delta \mathrm{P}_{\mathrm{g}} / \mathrm{L}\right)$ increased with aeration, and on the up ramp it flattened out around $50 \mathrm{lb} / \mathrm{ft}^{3}$ that corresponded to approximately $275 \mathrm{scfh}$ in the aeration. This is a typical minimum fluidization velocity determination, which appeared to have the same result as the shear stress. The gas pressure drop $\left(-\Delta \mathrm{P}_{\mathrm{g}} / \mathrm{L}\right)$ flattened at higher flows than the discontinuity in the shear stress, which suggests that shear stress may be a more sensitive measurement of fluidization. The velocity that corresponded to this point was approximately $1.5 \mathrm{ft} / \mathrm{sec}$.

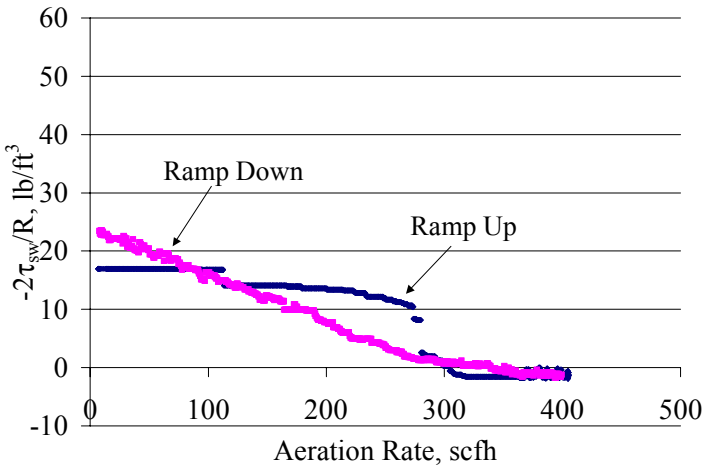

Figure 64 Shear Stress versus Aeration for a Stationary Bed, $230 \mu \mathrm{m}$ Coke

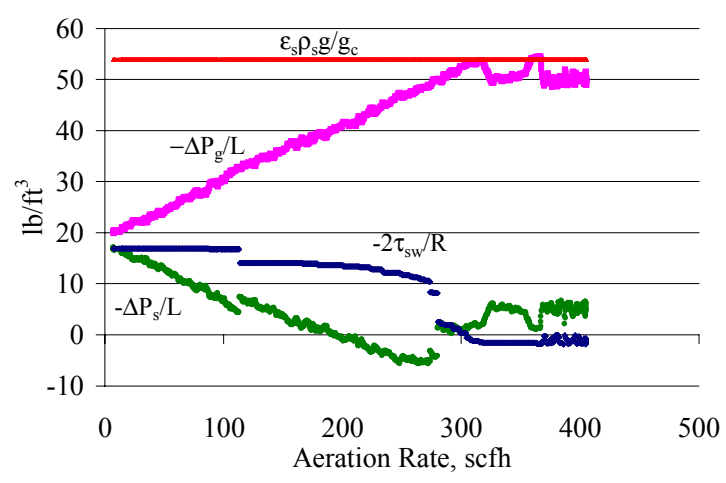

Figure 65: Momentum Balance Components for a Stationary Bed (Ramp Up), $230 \mu \mathrm{m}$ Coke

The solids pressure drop $\left(-\Delta \mathrm{P}_{\mathrm{s}} / \mathrm{L}\right)$ was found by difference using the mixture momentum balance, Equation (7) (Section 1.2). As in Figure 64 the magnitude of the solids pressure drop $\left(-\Delta \mathrm{P}_{\mathrm{s}} / \mathrm{L}\right)$ in Figure 65 decreased as the aeration increased. Also, note that if the bed was fluidized above $275 \mathrm{scfh}$, the method of estimation of solids pressure drop $\left(-\Delta \mathrm{P}_{\mathrm{s}} / \mathrm{L}\right)$ was flawed because one of the assumptions is a constant void fraction. Above fluidization, the solids volume fraction decreases with increasing aeration. This may lead to an estimation of larger magnitude of solids pressure drop $\left(-\Delta \mathrm{P}_{\mathrm{s}} / \mathrm{L}\right)$ than what 
is actually occurring because the actual solids volume fraction is lower than what is used to estimate solids pressure drop $\left(-\Delta \mathrm{P}_{\mathrm{s}} / \mathrm{L}\right)$.

Figure 65 illustrates the importance of each term in the mixture momentum balance as the aeration was increased. It is intuitive that the gas pressure drop $\left(-\Delta \mathrm{P}_{\mathrm{g}} / \mathrm{L}\right)$ increased with increasing aeration relieving shear stress at the wall and solids pressure drop $\left(-\Delta \mathrm{P}_{\mathrm{s}} / \mathrm{L}\right)$. At the point that the bed was assumed to be fluidized, $275 \mathrm{scfh}$, gas pressure drop $\left(-\Delta \mathrm{P}_{\mathrm{g}} / \mathrm{L}\right)$ had the largest magnitude contributing to the momentum balance, while shear stress $\left(-2 \tau_{\mathrm{sw}} / \mathrm{R}\right)$ and solids pressure drop $\left(-\Delta \mathrm{P}_{\mathrm{s}} / \mathrm{L}\right)$ were close to zero. Also note that at a very low aerations shear stress $\left(-2 \tau_{\mathrm{sw}} / \mathrm{R}\right)$ magnitudes were comparable to the magnitudes of the gas pressure drop $\left(-\Delta \mathrm{P}_{\mathrm{g}} / \mathrm{L}\right)$. This is similar to results presented for a moving standpipe in Chapter 4 (for coke breeze). This also supports the accepted method of including shear stress in models for standpipes that are in either packed bed or transitional packed regimes and neglecting shear stress in standpipes that are fluidized.

For completion the components of the momentum balance for the down ramp have been plotted against aeration in Figure 66. All of the trends discussed above apply here. However, the discontinuities seen in shear stress during the up ramps did not occur in the down ramps. In this case the bed was slowly compacting down.

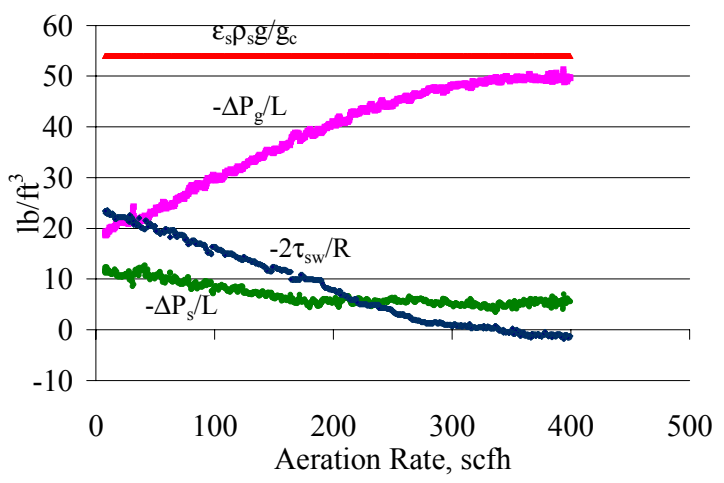

Figure 66: Momentum Balance Components for a Stationary Bed (Ramp Down), $230 \mu \mathrm{m}$ Coke

Another stationary bed aeration ramp test is worth mentioning, because it resulted in very different results. A list of variables and settings in this test is shown in Table 32 . Notice that all settings were similar except the riser flow in the above test was much lower than this test. A shear vane at 7' measured shear stress in this section. 
Table 32: Stationary Bed Aeration Ramp Variables, Riser Flow 50,000 scfh, $230 \mu \mathrm{m}$ Coke

\begin{tabular}{|c|c|c|}
\hline $\begin{array}{l}\text { Independent } \\
\text { Variables }\end{array}$ & $\begin{array}{c}\text { Dependent } \\
\text { Variables }\end{array}$ & $\begin{array}{l}\text { Controlled } \\
\text { Variables }\end{array}$ \\
\hline \multirow[t]{6}{*}{$\begin{array}{c}\text { Standpipe Aeration } \\
0 \text { to } 400 \mathrm{scfh}\end{array}$} & $\begin{array}{c}\text { Shear stress }-2^{*} \tau_{\mathrm{sw}} / \mathrm{R} \\
23 \text { to } 12 \mathrm{lbf} / \mathrm{ft}^{\wedge} 3\end{array}$ & $\begin{array}{l}\text { Loopseal Aeration } \\
0 \mathrm{scfh}\end{array}$ \\
\hline & $\begin{array}{c}\Delta \mathrm{P}_{\mathrm{g}} / \mathrm{L} \\
1.1 \text { to } 29 \mathrm{lbf} / \mathrm{ft}^{\wedge} 3\end{array}$ & $\begin{array}{l}\text { Riser Aeration } \\
50,000 \mathrm{scfh}\end{array}$ \\
\hline & $\begin{array}{c}\varepsilon \\
\text { not measured }\end{array}$ & $\begin{array}{l}\text { Aeration at } 15^{\prime} \\
0 \mathrm{scfh}\end{array}$ \\
\hline & $\begin{array}{c}\Delta \mathrm{P}_{\mathrm{s}} \\
48 \text { to } 5 \mathrm{lb} / \mathrm{ft}^{\wedge} 3\end{array}$ & $\begin{array}{c}\text { Aeration at } 7.5^{\prime} \\
0 \mathrm{scfh}\end{array}$ \\
\hline & $\begin{array}{c}\mathrm{v}_{\mathrm{g}} \\
\text { (unknown) }\end{array}$ & $\begin{array}{c}\text { Aeration at the bottom of } \\
\text { the standpipe } \\
0 \mathrm{scfh}\end{array}$ \\
\hline & & $\begin{array}{c}\text { Aeration at the dipleg } \\
0 \mathrm{scfh}\end{array}$ \\
\hline
\end{tabular}

There is one strong difference in this test as compared to the first one discussed. The riser flow is $50,000 \mathrm{scfh}$, which is 5 times that was used in the low riser flow test. Therefore, any solids that move into the riser were quickly returned to the standpipe. In the earlier test, the low riser flow was used to increase the amount of backpressure in the riser. The resulting difference is the amount of the aeration supplied to the standpipe that goes to the riser and the amount that goes up the standpipe. In the higher riser flow test, more aeration in the standpipe went toward the riser because there was less resistance to flow in the riser rather than the height of packed bed in the standpipe. In the lower riser flow test, more aeration went up the standpipe due to the $7^{\prime}$ fluid bed in the riser that resulted from low flow.

The riser flow was set at 50,000 scfh, and there was no aeration in the loopseal or along the standpipe except for the standpipe aeration at the bottom. The aeration was ramped from 20 to $400 \mathrm{scfh}$ at a rate of $20 \mathrm{scfh} / \mathrm{min}$.

Figure 67 is a plot of the components of the momentum balance versus standpipe aeration. There are two aspects that stand out when looking at Figure 67. The shear stress was almost flat with aeration, and the lack of noise in the shear stress signal. The flat profile can be explained by the low amount of aeration actually going up the standpipe due to the high riser flow as compared to the previous test where there was a 
significant amount of aeration rising through the standpipe. This low aeration also explains the lack of noise in the signal. There was more noise in the signal for the low riser flow test because of the fluctuations in the higher density bed in the riser. The pressure fluctuations in this bed caused the aeration split to vary more.

If Figure 67 is expanded, there are some interesting trends at higher aerations (Figure 68). It is interesting that the shear stress actually increased in magnitude at aerations of $300 \mathrm{scfh}$. It increased to a maximum and then started to decrease in magnitude. Further, it went through this maximum before the bed actually circulated at $375 \mathrm{scfh}$. The bed may in fact be rearranging and compacting while the stress magnitude was increasing.

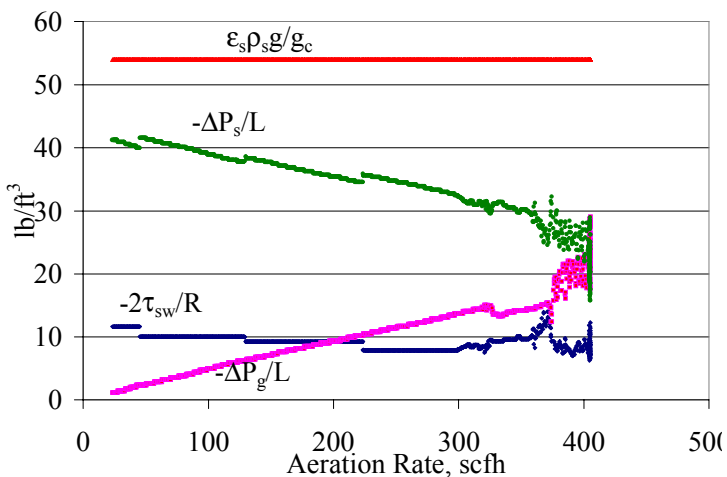

Figure 67: Momentum Balance Components for a Stationary Bed Ramp, High Riser Flow, $230 \mu \mathrm{m}$ Coke

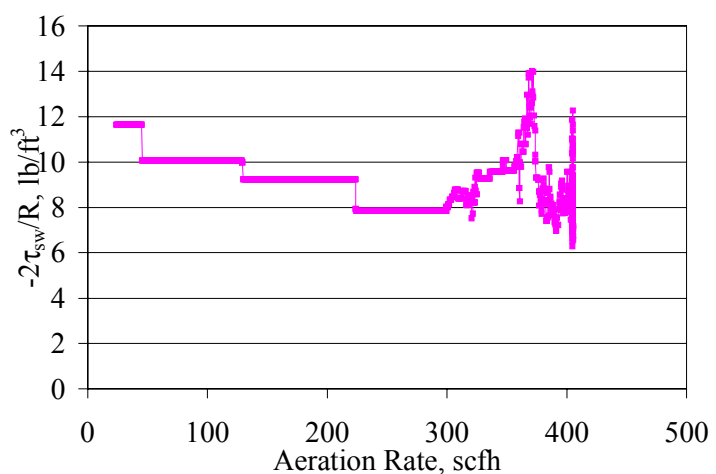

Figure 68: Shear Stress versus Aeration Rate, Stationary Bed, High Riser Flow, $230 \mu \mathrm{m}$ Coke

\section{2c Bubbling Bed Studies, Nylon Beads, in the 10” Test Bed}

Nylon beads, 1/8-inch diameter, were used in the bubbling test bed due to their size. This bed material was selected due to the issues regarding purge air discussed in Section $3.5 \mathrm{c}$. The particles were large enough not to get into the gap of the wall probe. In the test bed the aeration was increased from zero to $6,800 \mathrm{scfh}$. No nylon mesh or purge air was used.

The first aeration ramp is shown in Figure 69. In an increasing aeration ramp, the wall probe measured about half the shear stress measured by the shear vane. Although, the trends were similar for low aeration flows, at high flows the wall probe measurements went through a minimum, which was not exhibited by the shear vane. 
In Figure 70, the decreasing aeration trend is plotted. In the down ramp in aeration, the trends for both the wall probe and the shear vane were very similar. Also, the difference between the two was less than what was seen in the increasing aeration test. This suggested that there was either a hysteresis effect or a compaction effect.

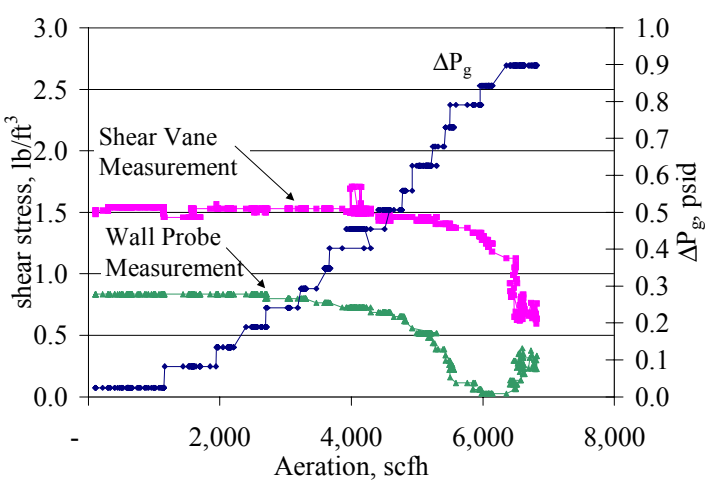

Figure 69: Bubbling Bed Aeration Ramp for Nylon Bead Bed Material

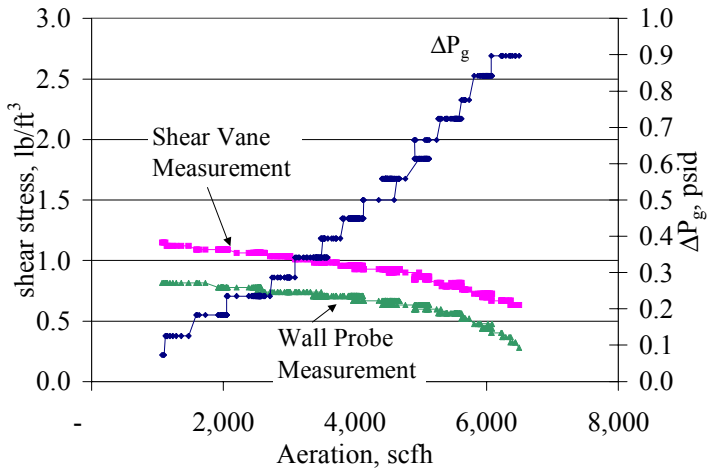

Figure 70: Bubbling Bed Aeration Ramp for Nylon Beads Bed Material, Decreasing Aeration

To see the effects of compaction, the bed was mechanically vibrated first, and then the aeration was increased over time, Figure 71. Comparing Figure 69 and Figure 71, much larger shear stress as measured by the wall probe were seen after the compaction. After the compaction, the wall probe measurements were significantly larger than the measurements by the shear vane for mid to lower flows. At high flows both instruments showed similar values. Like Figure 69, the minimum exhibited by the wall probe measurements at high flows was seen in Figure 71.

Figure 72 resulted when the aeration was decreased after compaction. The wall probe and shear vane had very similar results at high aeration in Figure 72. However, at lower aeration the wall probe measured higher stresses after compaction. It did not reach stress as high as seen in Figure 71, which still suggests a hysteresis effect. All four of the wall probe measurements have been plotted in Figure 73 to compare the difference between increasing aeration and decreasing aeration and to compare before and after compaction. All four of the shear vane measurements have been plotted in Figure 74. 


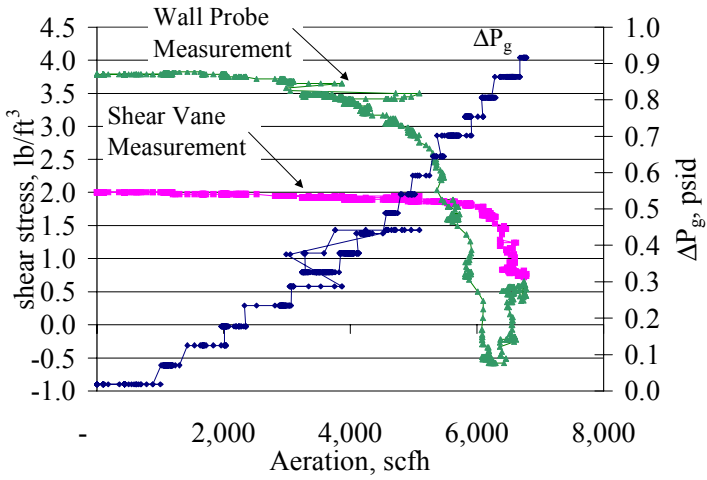

Figure 71: Bubbling Bed Aeration Ramp for Nylon Beads Bed Material, After Compaction

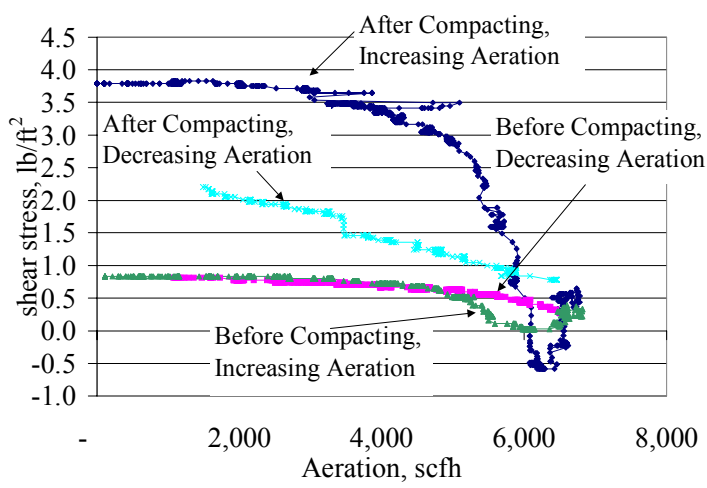

Figure 73: Comparison of the Wall Probe Measurements for the Nylon Bead Bubbling Bed Study

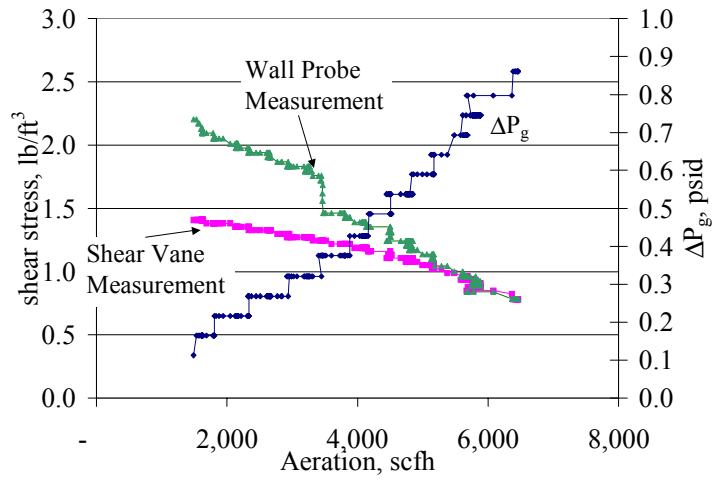

Figure 72: Bubbling Bed Aeration Ramp for Nylon Bead Bed Material, After Compaction, Decreasing Aeration

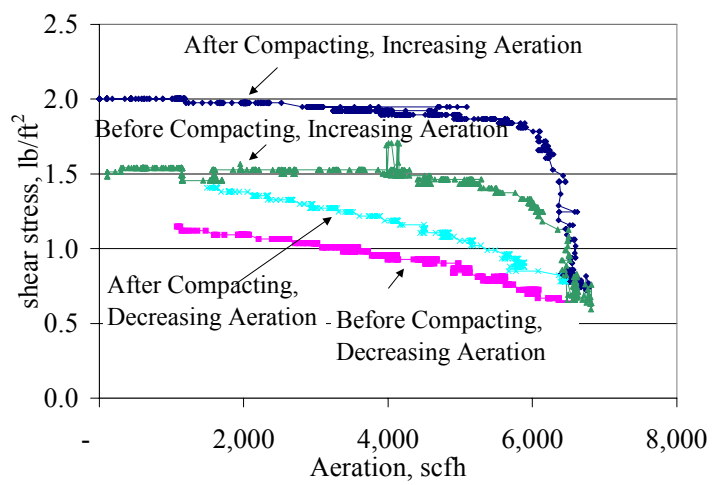

Figure 74: Comparison of the Shear Vane Measurements for the Nylon Bead Bubbling Bed Study

Compaction had a large effect on the wall probe and shear vane measurements (Figures 73 and 74), and at a high compaction the decreasing aeration trend gave a lower shear than the increasing aeration trend. Further, regardless of compaction the wall shear probe measurement exhibited a minimum at high flows for the increasing aeration trends. The impact of compaction gives insight into the importance of the history and stress state of the bed. In general, shear stress measurements from the shear vane do not approximate measurements from the wall probe. This suggests that either the shear stress at the center of the pipe is different then that at the wall, and/or that the measurement equipment are fundamentally different and are measuring different forces. 


\section{2d Bubbling Bed Studies, Cork, in the 10" Test Bed}

In the test bed the aeration was increased from zero to $500 \mathrm{scfh}$ for cork bed material. Nylon mesh was used for the wall probe as opposed to purge aeration. The bed height ranged from 28 to $32 \mathrm{ft}$.

In Figure 75 an increasing aeration trend is shown. As in the nylon bead study, the shear stress followed a similar trend of decreasing with increasing aeration. Further, the wall probe measured lower values than the shear vane. Also, the local solids volume fraction has been plotted in Figure 75. The probe described in Section 3.6 was used to measure it. This instrument was still in its early stages and is not necessarily trusted at this point obvious problems. However, the values reported in Figure 75 look reasonable and follow an intuitive trend. As aeration increased, solids volume fraction decreased.

Figure 76 is the corresponding decreasing aeration. There is a little more variability in the solids volume fraction measurements, but the values are reasonable. Further, the wall probe measurements do not increase up to the values seen in Figure 75. This is more evidence of a hysteresis effect. However, the shear vane shows measurements larger then that in Figure 75.

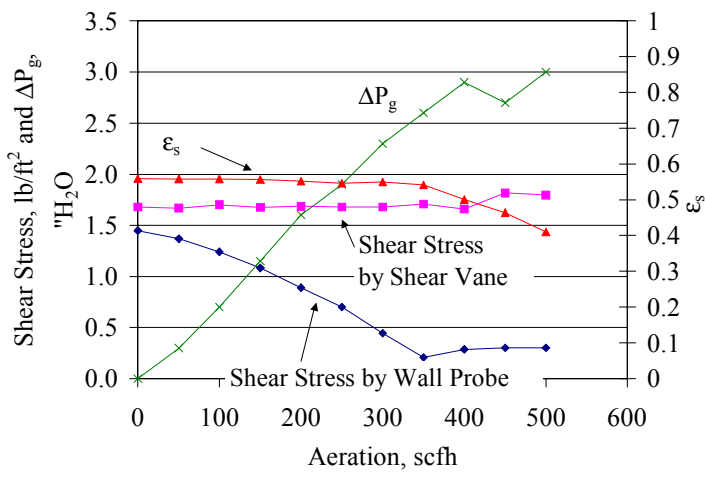

Figure 75: Bubbling Bed Aeration Ramp for Cork Bed Material

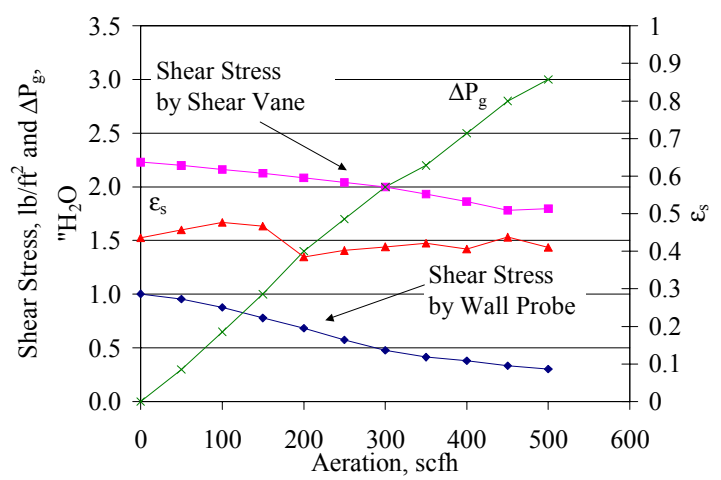

Figure 76: Bubbling Bed Aeration Ramp for Cork Bed Material, Decreasing Aeration

Figures 77 and 78 show another increasing/decreasing aeration ramp sequence. In this case unreasonable measurements of solids volume fraction measurements were seen. The trends in Figure 77 look reasonable except for the highest aeration rate at which 
point the solids volume fraction increases. The solids volume fraction measurements seen in Figure 78 are unreasonably high since the vibrated solids volume fraction has been estimated to be approximately 0.58 . Solids volume fraction measurements near 0.6 appear to be questionable. Solids volume fraction measurements of 0.88 cannot be correct. There are few speculations as to what caused these erroneous readings. The probe zero may have drifted. The calibration sequence described in Section $3.6 \mathrm{~b}$ may be poor. A dense piece of cork may be sitting in the measurement volume. Fines residue may be building up on the face of the probe.

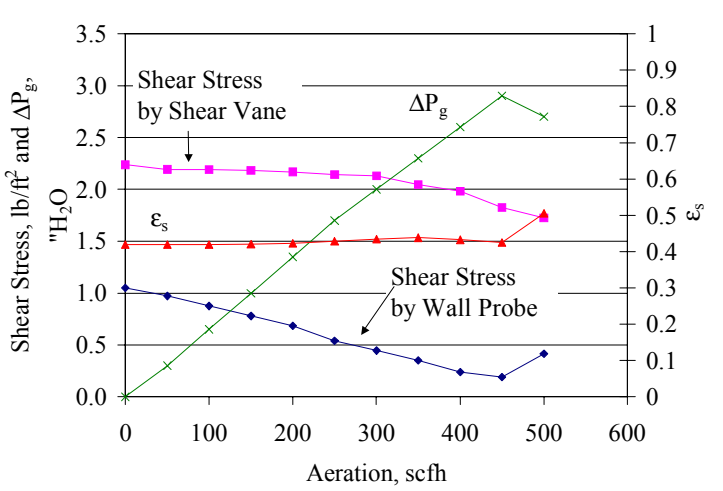

Figure 77: Bubbling Bed Ramp 2, Cork Bed Material, Increasing Aeration

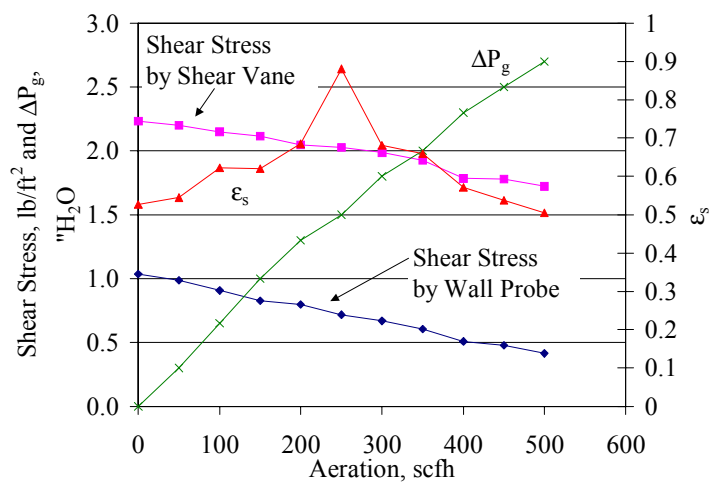

Figure 78: Bubbling Bed Ramp 2, Cork Bed Material, Decreasing Aeration

Further cork studies to understand the effects of purge air have been conducted and were summarized in Section 3.6b. From this study, we still do not have the capability to measure local solids volume fraction measurements. Either the probe readings or the calibration method is capable of giving unrealistic values at high aeration rates. Further, in general the shear vane did not give the same measurements as the wall probe. It is uncertain if this means that the shear at the center of the pipe is different from the shear at the wall, or if there is a fundamental difference between the measurements.

\section{2e Circulating Bed Aeration Ramp Tests}

Aeration ramps were performed to determine the effect of aeration alone on shear stress measurements in a circulating bed. Bed height in the standpipe was allowed to vary. Due to the split of aeration at the bottom of the standpipe fluidization states can only be presumed using the changes in pressure profile along the length of the standpipe. 
A list of variables and settings are shown in Table 33. Shear stress in this test was measured using a shear vane at the 7' level.

Table 33: Circulating Bed Aeration Ramp Variables, $230 \mu \mathrm{m}$ Coke

\begin{tabular}{|c|c|c|}
\hline $\begin{array}{l}\text { Independent } \\
\text { Variables }\end{array}$ & $\begin{array}{l}\text { Dependent } \\
\text { Variables }\end{array}$ & $\begin{array}{l}\text { Controlled } \\
\text { Variables }\end{array}$ \\
\hline \multirow[t]{8}{*}{$\begin{array}{l}\text { Standpipe Aeration } \\
0 \text { to } 400 \mathrm{scfh}\end{array}$} & $\begin{array}{c}\text { Shear stress } 2 * \tau_{\mathrm{sw}} / \mathrm{R} \\
26 \text { to } 9 \mathrm{lb} / \mathrm{ft}^{3}\end{array}$ & $\begin{array}{l}\text { Loopseal Aeration } \\
600 \mathrm{scfh}\end{array}$ \\
\hline & $\begin{array}{c}\Delta \mathrm{P}_{\mathrm{g}} / \mathrm{L} \\
0.3 \text { to } 26 \mathrm{lb} / \mathrm{ft}^{3}\end{array}$ & $\begin{array}{l}\text { Riser Aeration } \\
90,000 \mathrm{scfh}\end{array}$ \\
\hline & $\begin{array}{c}\varepsilon \\
\text { not measured } \\
\end{array}$ & $\begin{array}{l}\text { Aeration at } 15^{\prime} \\
25 \mathrm{scfh}\end{array}$ \\
\hline & $\begin{array}{c}\Delta \mathrm{P}_{\mathrm{s}} / \mathrm{L} \\
58 \text { to } 15 \mathrm{lb} / \mathrm{ft}^{\wedge} 3\end{array}$ & $\begin{array}{c}\text { Aeration at } 7.5^{\prime} \\
25 \mathrm{scfh}\end{array}$ \\
\hline & $\begin{array}{c}\mathrm{V}_{\mathrm{g}} \\
\text { (unknown) }\end{array}$ & $\begin{array}{c}\text { Aeration at the bottom of } \\
\text { the standpipe } \\
0 \mathrm{scfh}\end{array}$ \\
\hline & $\begin{array}{c}\text { Height of standpipe } \\
28 \text { to } 23 \mathrm{ft}\end{array}$ & $\begin{array}{l}\text { Aeration at the dipleg } \\
80 \mathrm{scfh}\end{array}$ \\
\hline & $\begin{array}{c}\text { Vs } \\
189 \text { to } 2,342.8 \mathrm{lb} / \mathrm{hr}\end{array}$ & $\begin{array}{c}\text { Total Inventory } \\
8561 \mathrm{bm}\end{array}$ \\
\hline & $\begin{array}{c}\text { Mass Circulation } \\
3,500 \text { to } 69,0001 \mathrm{bm} / \mathrm{hr}\end{array}$ & \\
\hline
\end{tabular}

A slow circulation of about $3,500 \mathrm{lb} / \mathrm{hr}$ was established with standpipe aeration of $50 \mathrm{scfh}$, riser flow of $90,000 \mathrm{scfh}$, and loopseal aeration of $600 \mathrm{scfh}$. The standpipe was then ramped to $400 \mathrm{scfh}$ at a rate of $20 \mathrm{scfh} / \mathrm{min}$. The standpipe bed height was allowed to vary.

Figure 79 is a plot of the change in momentum balance components with aeration rate. The wall shear stress magnitude decreased with increasing aeration. There were changes in slopes similar to what was seen in Chapter 4 . The curve appeared to be flat from 50 to just above $100 \mathrm{scfh}$. Between 100 and $300 \mathrm{scfh}$ it was steep and after 300 it appeared to be flat again. The magnitude of the shear stress component seen in this test was slightly larger than what was seen in the stationary cases. The shear stress components in the stationary cases were from 23 to about zero $\mathrm{lb} / \mathrm{ft}^{3}$. The shear stress component in this circulating case was from 28 to $5 \mathrm{lb} / \mathrm{ft}^{3}$, which was very similar to what was seen in Chapter 4. Other differences between this ramp and the stationary ramp were 
staged aeration. There was $25 \mathrm{scfh}$ at $15^{\prime}$, and $7.5^{\prime}$ in this situation. This aeration may have compressed the bed around the shear vane.

Keep that in mind other variables were changing along with the aeration. As aeration in the standpipe increased the bed height in the standpipe decreased and the mass circulation increased (Figure 80).

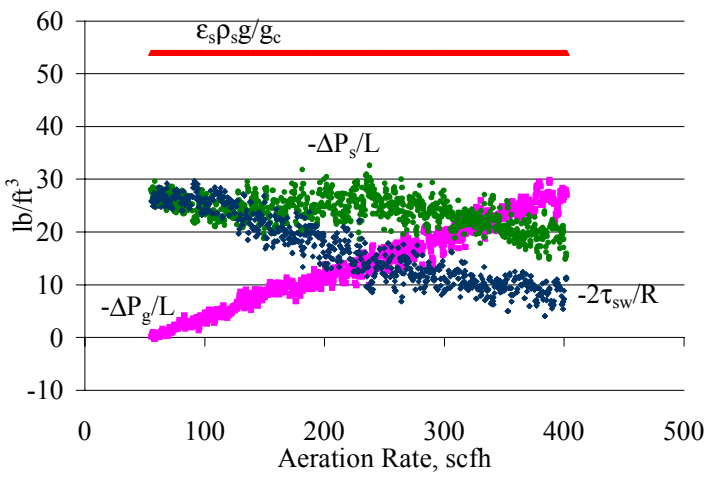

Figure 79: Momentum Balance Components for a Circulating Bed Aeration Ramp, $230 \mu \mathrm{m}$ Coke

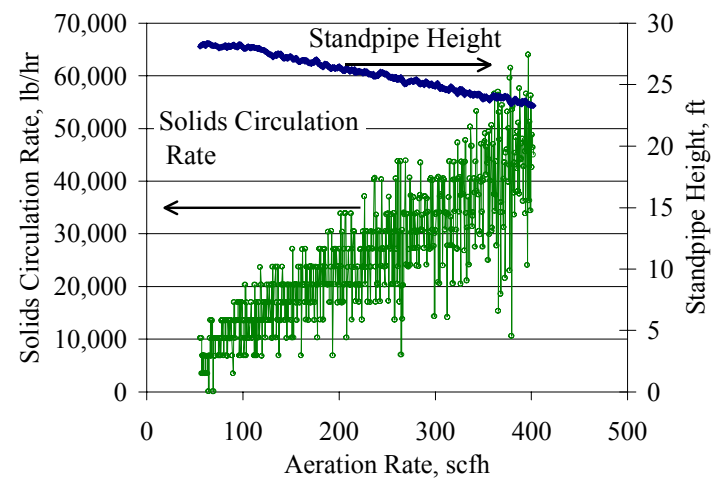

Figure 80: Mass Circulation and Standpipe Bed Height versus Aeration rate, $230 \mu \mathrm{m}$ Coke

The gas pressure drop $\left(-\Delta \mathrm{P}_{\mathrm{g}} / \mathrm{L}\right)$ increased in magnitude almost linearly with aeration (Figure 79). The magnitude increased from almost zero to about $30 \mathrm{lb} / \mathrm{ft}^{3}$. Like wall shear stress $\left(-2 \tau_{\mathrm{sw}} / \mathrm{R}\right)$ the magnitude of the solids pressure drop $\left(-\Delta \mathrm{P}_{\mathrm{s}} / \mathrm{L}\right)$ decreased with standpipe aeration. Note that if the standpipe was fluidized during the ramp, the method of estimation of the solids pressure drop $\left(-\Delta \mathrm{P}_{\mathrm{s}} / \mathrm{L}\right)$ was flawed because one of the assumptions was a constant void fraction. If the bed was fluidized or in a transitional packed bed state, then according to Leung (1985) the void fraction increased with gas velocity. The solids volume fraction was decreasing. This may have lead to an estimation of larger magnitude of solids pressure drop per unit length than what was actually occurring because the actual solids volume fraction was lower than what was used to estimate the solids pressure drop. Because a portion of the aeration fed to the standpipe splits and goes towards the riser, it is difficult to determine the gas velocity and corresponding fluidization state.

A similar experiment was run with ramping standpipe aeration, but with a different aeration scheme. A list of variables and settings is shown in Table 34. 
Table 34: Circulating Bed Aeration Ramp Variables, Aeration at the Bottom, 230 $\mu \mathrm{m}$ Coke

\begin{tabular}{|c|c|c|}
\hline $\begin{array}{l}\text { Independent } \\
\text { Variables }\end{array}$ & $\begin{array}{l}\text { Dependent } \\
\text { Variables }\end{array}$ & $\begin{array}{l}\text { Controlled } \\
\text { Variables }\end{array}$ \\
\hline \multirow[t]{7}{*}{$\begin{array}{l}\text { Standpipe Aeration } \\
0 \text { to } 400 \mathrm{scfh}\end{array}$} & $\begin{array}{c}\text { Shear stress } 2^{*} \tau_{\mathrm{sw}} / \mathrm{R} \\
9 \text { to } 3 \mathrm{lb} / \mathrm{ft}^{3}\end{array}$ & $\begin{array}{l}\text { Loopseal Aeration } \\
500 \mathrm{scfh}\end{array}$ \\
\hline & $\begin{array}{c}\Delta \mathrm{P}_{\mathrm{g}} / \mathrm{L} \\
1 \text { to } 32 \mathrm{lb} / \mathrm{ft}^{3}\end{array}$ & $\begin{array}{l}\text { Riser Aeration } \\
95,000 \mathrm{scfh}\end{array}$ \\
\hline & $\begin{array}{c}\varepsilon \\
\text { not measured }\end{array}$ & $\begin{array}{l}\text { Aeration at } 15^{\prime} \\
25 \mathrm{scfh}\end{array}$ \\
\hline & $\begin{array}{c}\Delta \mathrm{P}_{\mathrm{s}} / \mathrm{L} \\
43 \text { to } 17 \mathrm{lb} / \mathrm{ft}^{\wedge} 3\end{array}$ & $\begin{array}{l}\text { Aeration at } 7.5^{\prime} \\
25 \mathrm{scfh}\end{array}$ \\
\hline & $\begin{array}{c}\mathrm{V}_{\mathrm{g}} \\
\text { (unknown) }\end{array}$ & $\begin{array}{c}\text { Aeration at the bottom of } \\
\text { the standpipe } \\
100 \mathrm{scfh}\end{array}$ \\
\hline & $\begin{array}{c}\text { Mass Circulation } \\
10,000 \text { to } 74,000 \mathrm{lb} / \mathrm{hr}\end{array}$ & $\begin{array}{l}\text { Aeration at the dipleg } \\
90 \mathrm{scfh}\end{array}$ \\
\hline & & $\begin{array}{c}\text { Total Inventory } \\
1000 \mathrm{lbm}\end{array}$ \\
\hline
\end{tabular}

Figure 81 is a plot of the momentum balance components versus aeration rate. Although in Figure 79 there were similar trends to Figure 81, the shear stress values were much lower in Figure 81. One large difference between the two tests was the location of the aeration at the bottom of the standpipe. For the test depicted in Figure $81100 \mathrm{scfh}$ was always applied to the very bottom of the standpipe. Furthermore, solids circulation rates achieved in this ramp were from 10,000 to $74,000 \mathrm{lb} / \mathrm{hr}$, which was higher than those achieved in Figure 79, which were 3,500 to 69,000 lb/hr.

As a result, aeration located at the bottom of the standpipe had not only a large impact on solids circulation, but also a large impact on measure shear stress values. 


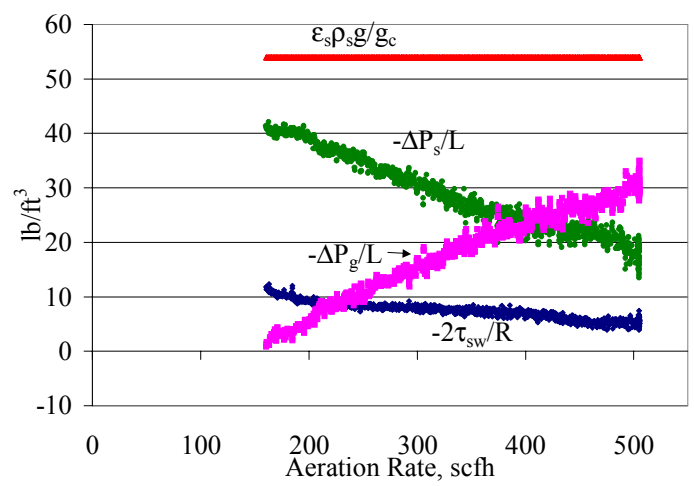

Figure 81: Momentum Balance Components for a Circulating Bed Aeration Ramp, Aeration at the Bottom, $230 \mu \mathrm{m}$ Coke

\section{2f Circulating Bed Aeration Ramp Tests - Low Flows}

A few aeration ramps at lower flows gave very different qualitative information regarding shear stress then what was discussed in section 5.2e. All of the aeration ramps presented in Chapter 4 and 5 start with aeration rates of $50 \mathrm{scfh}$. From this study, the ramps were run from 0 to $150 \mathrm{scfh}$.

An example of the how lower flows effect shear stress is in Figure 82. A shear vane at 7' was used to measure the shear stress in this section. In Figure 82, initially, the shear stress component increased with increasing aeration rate. It reached a maximum, and then decreased with increasing aeration rate. In Chapter 4 and Section 5.2e, the shear stress always decreased with increasing aeration. However, aeration rates below $50 \mathrm{scfh}$ were not seen in Chapter 4 and Section 5.2e.

In Figure 83, the shear stress component and gas pressure drop are plotted as a function of aeration (move air). As mentioned above, at low flows as aeration rate increased shear stress increased to a maximum after which it started to decrease. From Figure 83, as the aeration increased the gas pressure drop increased. However, at low flows the gas pressure drop was negative, which meant that the gas phase was pushing down, and the gas flow was flowing down. After a certain point, approximately $130 \mathrm{scfh}$ the gas pressure drop became positive, which meant that the gas pressure was pushing up on the bed and the gas was flowing up. 


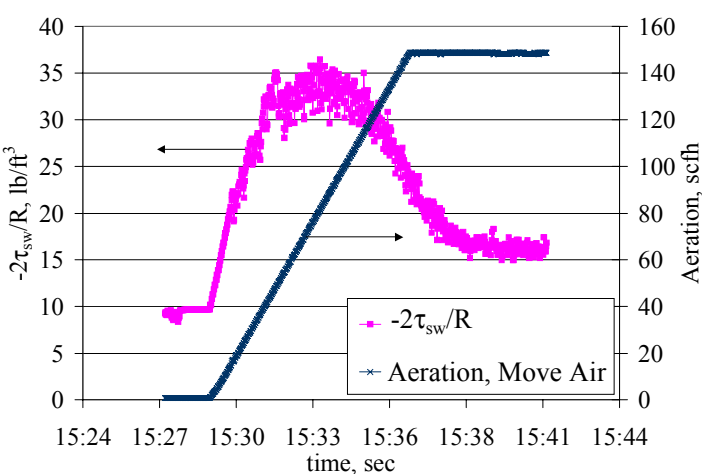

Figure 82: Shear Stress at Lower Aeration Ramps, $230 \mu \mathrm{m}$ Coke

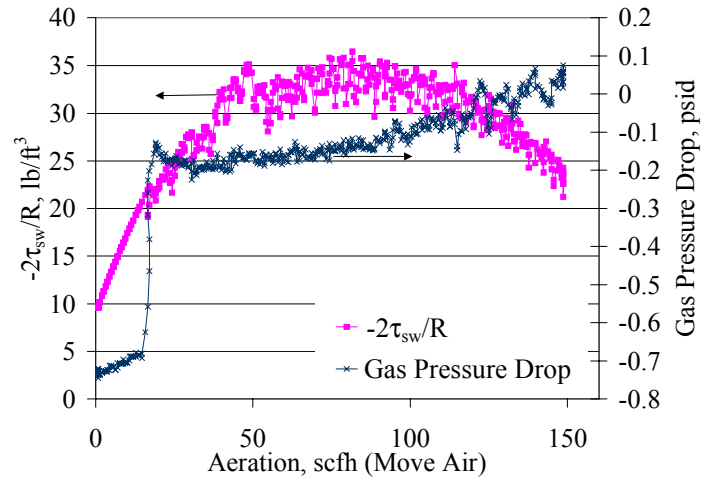

Figure 83: Shear Stress Component and Gas Pressure Drop versus Aeration Rate for Low Flows, $230 \mu \mathrm{m}$ Coke

All of the momentum balance components are shown in Figure 84. In Figure 84, the shear stress component was the largest force other than the weight of the bed. For most of the aeration ramp, the gas pressure drop component was negative which was added to the force necessary for the shear stress component and solids pressure component to balance.

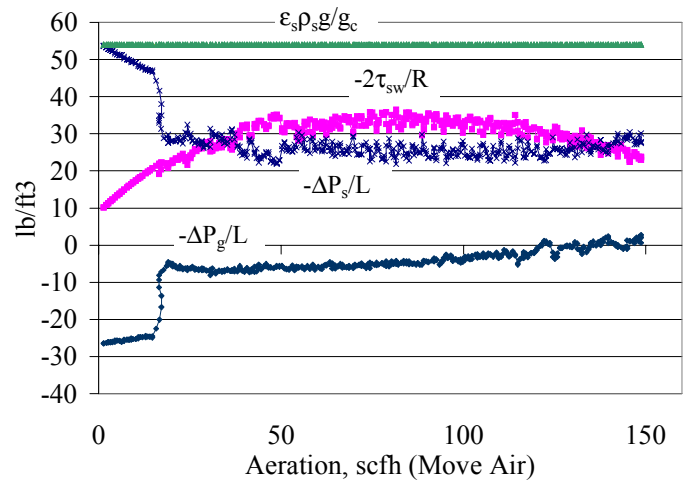

Figure 84: Momentum Balance Components versus Aeration for Low Flows, 230 $\mu \mathrm{m}$ Coke

At low flows for coke breeze, the shear stress was the largest component, and the gas pressure drop $\left(-\Delta \mathrm{P}_{\mathrm{g}} / \mathrm{L}\right)$ was working in the direction of the weight of the bed. Furthermore, the shear stress component at low flows increased with aeration and went through a maximum after which point it decreased with increasing aeration. 


\subsection{CFB Operational Variables}

Section 5.1 studied the effects of theoretical variables on shear stress. Section 5.2 was a qualitative study of shear stress using the aeration ramp to study effects such as hysteresis and compaction. In this section statistical, factorial studies were used to understand the effects of CFB operational variables. In Section 5.1, gas pressure drop ($\left.\Delta \mathrm{P}_{\mathrm{g}} / \mathrm{L}\right)$ was an independent variable, and it appeared to have an impact on the solids wall shear stress. In this section gas pressure drop $\left(-\Delta \mathrm{P}_{\mathrm{g}} / \mathrm{L}\right)$ was a dependent variable, and factors that effect it as well as the shear stress component and solids pressure drop ($\left.\Delta \mathrm{P}_{\mathrm{S}} / \mathrm{L}\right)$ were studied.

\section{3a The Effect of Solids Circulation Rate and Riser Pressure Drop}

A two-factor experiment was run to understand the effect of riser pressure and solids circulation rate on shear stress. An increase in riser pressure resulted in a corresponding increase in the incremental standpipe pressure. This pressure increase changed the aeration split at the bottom of the standpipe. Furthermore, changing solids circulation rate and the pressure drop in the riser changed the relative velocity in the standpipe. Therefore, the balance of the forces in the standpipe changed. Table 35 lists the runs made to understand these variables using a fully duplicated and randomized $2 \mathrm{X} 2$ factorial test.

Table 35: Riser Pressure Drop and Solids Circulation Rate Test Independent Variables, $230 \mu \mathrm{m}$ Coke

\begin{tabular}{|c|c|c|}
\hline$\underline{\text { Run }}$ & $\begin{array}{c}\text { Riser Pressure Drop } \\
\mathbf{p s i}\end{array}$ & $\begin{array}{c}\text { Solids Circulation Rate } \\
\mathbf{l b} / \mathrm{hr}\end{array}$ \\
\hline 1 & 1.5 & 10,000 \\
\hline 2 & 1.5 & 25,000 \\
\hline 3 & 2.0 & 10,000 \\
\hline 4 & 2.0 & 25,000 \\
\hline 5 & 1.5 & 10,000 \\
\hline 6 & 1.5 & 25,000 \\
\hline 7 & 2.0 & 10,000 \\
\hline 8 & 2.0 & 25,000 \\
\hline
\end{tabular}

The results from these runs were summarized in Table 36. Notice that the bed height was relatively constant. A shear vane at 7' was used to measure the shear stress in this experiment. 
Table 36: Riser Pressure Drop and Solids Circulation Rate Test Results, $230 \mu \mathrm{m}$ Coke

\begin{tabular}{|c|c|c|c|c|c|c|c|}
\hline$\underline{\mathbf{R u n}}$ & $\begin{array}{c}\text { Riser } \\
\text { Pressure } \\
\text { Drop } \\
\mathbf{p s i}\end{array}$ & $\begin{array}{c}\text { Solids } \\
\text { Circulation } \\
\text { Rate } \\
\mathbf{l b} / \mathbf{h r}\end{array}$ & $\begin{array}{c}\text { Standpipe } \\
\text { Height } \\
\mathbf{f t}\end{array}$ & $\begin{array}{c}\text { Shear } \\
\text { Stress } \\
\mathbf{l b / \mathbf { f t } ^ { \mathbf { 2 } }}\end{array}$ & $\begin{array}{c}\mathbf{- 2 * S h e a r} \\
\mathbf{S t r e s s} / \mathbf{R} \\
\mathbf{l b} / \mathbf{f t}^{\mathbf{2}}\end{array}$ & $\begin{array}{c}-\Delta \mathbf{P}_{\mathbf{g}} / \mathbf{L} \\
\mathbf{\mathbf { l b }} / \mathbf{f t}^{\mathbf{2}}\end{array}$ & $\begin{array}{c}-\Delta \mathbf{P}_{\mathbf{s}} / \mathbf{L} \\
\mathbf{l b} / \mathbf{f t}^{\mathbf{2}}\end{array}$ \\
\hline 1 & 1.48 & 11,365 & 21 & 3.02 & 14.51 & 23.06 & 16.43 \\
\hline 2 & 1.51 & 24,653 & 19 & 1.10 & 5.29 & 31.06 & 17.65 \\
\hline 3 & 1.97 & 13,461 & 19 & 2.65 & 12.71 & 29.18 & 12.1 \\
\hline 4 & 2.01 & 24,291 & 19 & 1.53 & 7.32 & 33.64 & 13.03 \\
\hline 5 & 1.51 & 11,339 & 19 & 1.18 & 5.67 & 26.22 & 22.11 \\
\hline 6 & 1.51 & 24,490 & 19 & 0.63 & 3.01 & 29.23 & 21.76 \\
\hline 7 & 2.00 & 12,581 & 19 & 1.48 & 7.11 & 30.55 & 16.34 \\
\hline 8 & 1.99 & 23,583 & 16.5 & 1.20 & 5.78 & 37.87 & 10.35 \\
\hline
\end{tabular}

Figures 85 through 87 illustrate these results graphically. Notice that the pressure drop in the riser is denoted as DPr.

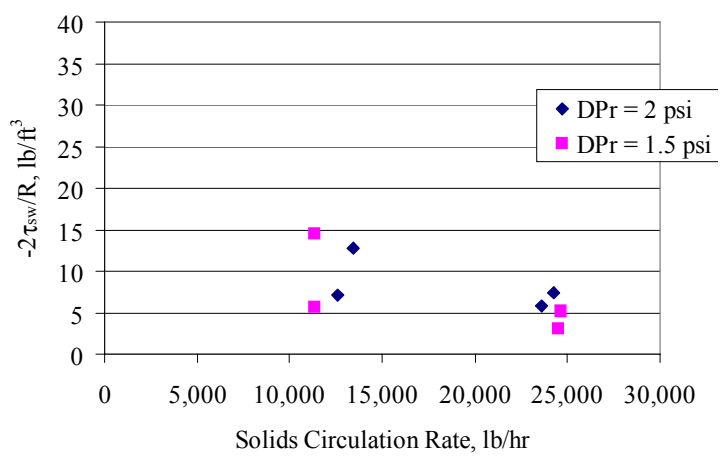

Figure 85: Shear Stress $\left(-2 \tau_{\mathrm{sw}} / \mathrm{R}\right)$ Results of $2 \times 2$ factorial, Riser $\Delta \mathrm{P}$ and Solids Circulation Rate, $230 \mu \mathrm{m}$ Coke

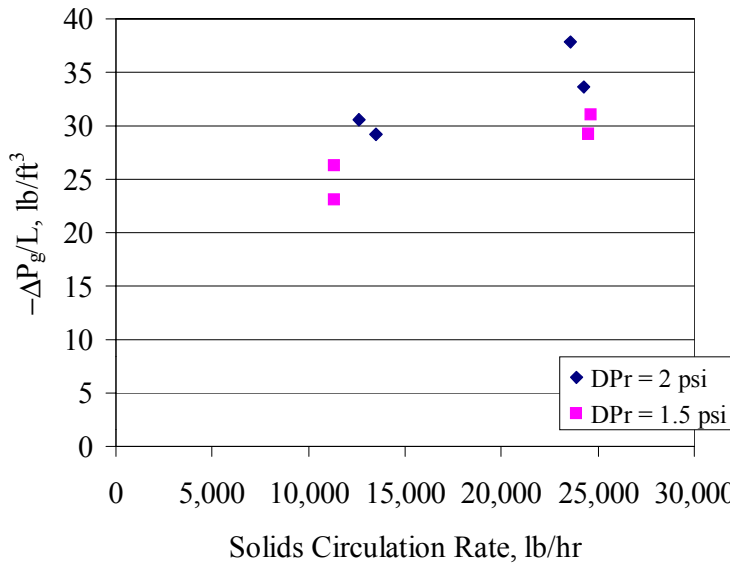

Figure 86: Gas Pressure Drop (- $\left.\Delta \mathbf{P}_{\mathrm{g}} / \mathbf{L}\right)$ Results of $2 \times 2$ factorial, Riser $\Delta P$ and Solids Circulation Rate, $230 \mu \mathrm{m}$ Coke 


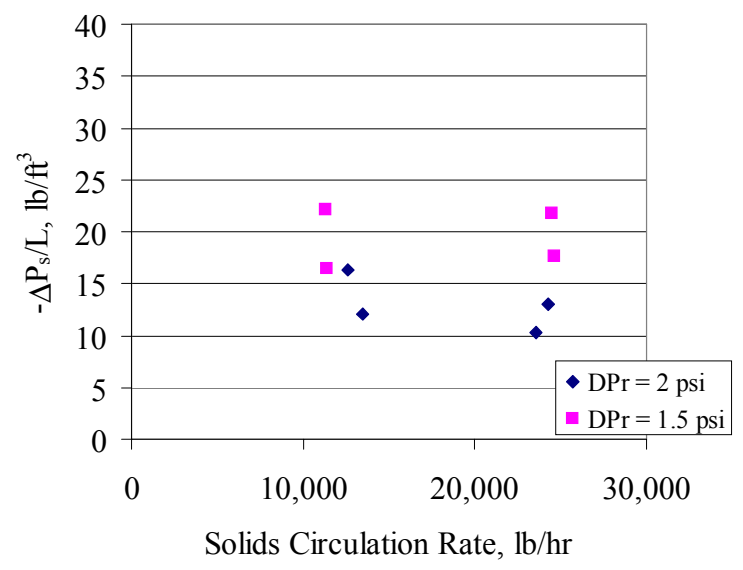

\section{Figure 87: Solids Pressure Drop $\left(-\Delta P_{s} / L\right)$ Results of $2 X 2$ factorial, Riser $\Delta P$ and Solids Circulation Rate, $230 \mu \mathrm{m}$ Coke}

A type I sum of squares analyses was applied to the three dependent variables listed in Table 36. Table 37 describes the results for the shear stress component of the momentum balance. Notice that pressure drop in the riser is denoted as DPR and solids circulation rate is denoted as MS.

Table 37: ANOVA of Riser Pressure drop and Solids Circulation Test for Shear Stress $\left(-2 \tau_{\mathrm{sw}} / \mathbf{R}\right), 230 \mu \mathrm{m}$ Coke

Tests of Between-Subjects Effects

Dependent Variable: shear stress

\begin{tabular}{|c|c|c|c|c|c|c|c|c|}
\hline Source & $\begin{array}{c}\text { Type I } \\
\text { Sum of } \\
\text { Squares }\end{array}$ & df & $\begin{array}{c}\text { Mean } \\
\text { Square }\end{array}$ & $F$ & Sig. & $\begin{array}{c}\text { Eta } \\
\text { Squared }\end{array}$ & $\begin{array}{l}\text { Noncent. } \\
\text { Parameter }\end{array}$ & $\begin{array}{c}\text { Observed } \\
\text { Power }^{\mathrm{a}}\end{array}$ \\
\hline $\begin{array}{l}\text { Corrected } \\
\text { Model }\end{array}$ & $49.037^{b}$ & 3 & 16.346 & 1.117 & .441 & .456 & 3.351 & .149 \\
\hline Intercept & 471.245 & 1 & 471.245 & 32.201 & .005 & .890 & 32.201 & .984 \\
\hline DPR & 2.464 & 1 & 2.464 & .168 & .703 & .040 & .168 & .062 \\
\hline MS & 43.245 & 1 & 43.245 & 2.955 & .161 & .425 & 2.955 & .264 \\
\hline $\mathrm{DPR}$ * MS & 3.328 & 1 & 3.328 & .227 & .658 & .054 & .227 & .066 \\
\hline Error & 58.538 & 4 & 14.634 & & & & & \\
\hline Total & 578.820 & 8 & & & & & & \\
\hline $\begin{array}{l}\text { Corrected } \\
\text { Total }\end{array}$ & 107.575 & 7 & & & & & & \\
\hline
\end{tabular}

a. Computed using alpha $=0.05$

b. $\mathrm{R}$ Squared $=.456$ (Adjusted R Squared $=.048$ )

Section 3.5c discussed the information given in the ANOVA table in detail. From Table 37 no variable variables were significant. The model explains only $4.8 \%$ of the variability of shear stress. The independent variables were not the right variables to 
explain the variability seen in the shear stress. The variability between the replicates was as large as the variability from level to level of the controlled variables.

Due to Section 5.1 it was not surprising that solids circulation rate did not have a significant effect on the shear stress. However, Section 5.1 suggested that gas pressure drop $\left(-\Delta \mathrm{P}_{\mathrm{g}} / \mathrm{L}\right)$ affected shear stress. If the riser pressure was significant for gas pressure drop $\left(-\Delta \mathrm{P}_{\mathrm{g}} / \mathrm{L}\right)$, then it could have had an effect on the shear stress $\left(-2 \tau_{\mathrm{sw}} / \mathrm{R}\right)$. The ANOVA results for gas pressure drop $\left(-\Delta \mathrm{P}_{\mathrm{g}} / \mathrm{L}\right)$ in the standpipe section around the shear vane are in Table 38.

\section{Table 38: ANOVA of Riser Pressure drop and Solids Circulation Test for Gas Pressure Drop $\left(-\Delta \mathbf{P}_{\mathrm{g}} / \mathrm{L}\right), 230 \mu \mathrm{m}$ Coke}

Tests of Between-Subjects Effects

Dependent Variable: Pressure Drop per Unit Length across shear vane interval

\begin{tabular}{|c|c|c|c|c|c|c|c|c|}
\hline Source & $\begin{array}{c}\text { Type I } \\
\text { Sum of } \\
\text { Squares }\end{array}$ & df & $\begin{array}{c}\text { Mean } \\
\text { Square }\end{array}$ & $\mathrm{F}$ & Sig. & $\begin{array}{c}\text { Eta } \\
\text { Squared }\end{array}$ & $\begin{array}{l}\text { Noncent. } \\
\text { Parameter }\end{array}$ & $\begin{array}{c}\text { Observed } \\
\text { Power }^{a}\end{array}$ \\
\hline $\begin{array}{l}\text { Corrected } \\
\text { Model }\end{array}$ & $123.809^{b}$ & 3 & 41.270 & 9.961 & .025 & .882 & 29.882 & .795 \\
\hline Intercept & 7249.808 & 1 & 7249.808 & 1749.774 & .000 & .998 & 1749.774 & 1.000 \\
\hline DPR & 58.750 & 1 & 58.750 & 14.179 & .020 & .780 & 14.179 & .801 \\
\hline MS & 64.988 & 1 & 64.988 & 15.685 & .017 & .797 & 15.685 & .837 \\
\hline DPR * MS & 7.214E-02 & 1 & 7.214E-02 & .017 & .901 & .004 & .017 & .051 \\
\hline Error & 16.573 & 4 & 4.143 & & & & & \\
\hline Total & 7390.190 & 8 & & & & & & \\
\hline $\begin{array}{l}\text { Corrected } \\
\text { Total }\end{array}$ & 140.382 & 7 & & & & & & \\
\hline
\end{tabular}

a. Computed using alpha $=0.05$

b. $\mathrm{R}$ Squared $=.882($ Adjusted $\mathrm{R}$ Squared $=.793)$

Unlike the shear stress component model, the main effects were significant, and were almost equal in magnitude of importance according to Eta squared. From Figure 86 it was apparent that an increase in solids circulation rate and riser pressure drop both resulted in an increase in gas pressure drop $\left(-\Delta \mathrm{P}_{\mathrm{g}} / \mathrm{L}\right)$ in the control volume.

ANOVA results for solids pressure $\left(-\Delta \mathrm{P}_{\mathrm{s}} / \mathrm{L}\right)$ as calculated from the force balance in the control volume are in Table 39. 


\section{Table 39: ANOVA of Riser Pressure drop and Solids Circulation Test for Solids Pressure Drop $\left(-\Delta \mathbf{P}_{\mathrm{s}} / \mathrm{L}\right), 230 \mu \mathrm{m}$ Coke}

Tests of Between-Subjects Effects

Dependent Variable: Solids Pressure drop per unit length

\begin{tabular}{|c|c|c|c|c|c|c|c|c|}
\hline Source & $\begin{array}{l}\text { Type I } \\
\text { Sum of } \\
\text { Squares }\end{array}$ & $\mathrm{df}$ & $\begin{array}{c}\text { Mean } \\
\text { Square }\end{array}$ & $\mathrm{F}$ & Sig. & $\begin{array}{c}\text { Eta } \\
\text { Squared }\end{array}$ & $\begin{array}{l}\text { Noncent. } \\
\text { Parameter }\end{array}$ & $\begin{array}{c}\text { Observed } \\
\text { Power }^{a}\end{array}$ \\
\hline $\begin{array}{l}\text { Corrected } \\
\text { Model }\end{array}$ & $91.937^{b}$ & 3 & 30.646 & 3.299 & .140 & .712 & 9.897 & .358 \\
\hline Intercept & 2105.032 & 1 & 2105.032 & 226.608 & .000 & .983 & 226.608 & 1.000 \\
\hline DPR & 85.347 & 1 & 85.347 & 9.188 & .039 & .697 & 9.188 & .628 \\
\hline MS & 2.195 & 1 & 2.195 & .236 & .652 & .056 & .236 & .067 \\
\hline $\mathrm{DPR} * \mathrm{MS}$ & 4.396 & 1 & 4.396 & .473 & .529 & .106 & .473 & .084 \\
\hline Error & 37.157 & 4 & 9.289 & & & & & \\
\hline Total & 2234.126 & 8 & & & & & & \\
\hline $\begin{array}{l}\text { Corrected } \\
\text { Total }\end{array}$ & 129.094 & 7 & & & & & & \\
\hline
\end{tabular}

a. Computed using alpha $=0.05$

b. $\mathrm{R}$ Squared $=.712$ (Adjusted R Squared $=.496)$

Like in the gas pressure drop across the shear vane $\left(-\Delta \mathrm{P}_{\mathrm{g}} / \mathrm{L}\right)$ model, the riser pressure drop was significant for the solids phase pressure drop $\left(-\Delta \mathrm{P}_{\mathrm{s}} / \mathrm{L}\right)$. From Figure 87 it can be seen that an increase in riser pressure drop resulted in a decrease in solids pressure drop $\left(-\Delta \mathrm{P}_{\mathrm{g}} / \mathrm{L}\right)$ in the control volume.

\section{3b Four Factor Test: Standpipe Height, Riser Flow, Loopseal Flow, and Solids}

\section{Circulation Rate}

A four-factor experiment was run to understand the effect of riser flow, solids circulation rate, standpipe height, and loopseal flow on shear stress. It was felt that changes in these variables could change the aeration split and pressure drop across the interval of interest. Changes in these variables could also change the relative velocity and the void fraction in the interval of interest. Therefore, the balance of the forces in the standpipe would change. Table 40 lists the runs made to understand these variables. 
Table 40: Four Factor Test Independent Variables

\begin{tabular}{|c|c|c|c|c|}
\hline$\underline{\text { Run }}$ & $\begin{array}{c}\text { Riser Flow } \\
\mathbf{f t} / \mathbf{s e c}\end{array}$ & $\begin{array}{c}\text { Solids } \\
\text { Circulation Rate } \\
\mathbf{l b / h \mathbf { l }}\end{array}$ & $\begin{array}{c}\text { Standpipe } \\
\text { Height } \\
\mathbf{f t}\end{array}$ & $\begin{array}{c}\text { Loopseal Flow } \\
\text { scfh }\end{array}$ \\
\hline 1 & 15.9 & 12,500 & 16.5 & 600 \\
\hline 2 & 15.9 & 12,500 & 16.5 & 1200 \\
\hline 3 & 15.9 & 12,500 & 19.0 & 600 \\
\hline 4 & 15.9 & 12,500 & 19.0 & 1200 \\
\hline 5 & 15.9 & 25,000 & 16.5 & 600 \\
\hline 6 & 15.9 & 25,000 & 16.5 & 1200 \\
\hline 7 & 15.9 & 25,000 & 19.0 & 600 \\
\hline 8 & 15.9 & 25,000 & 19.0 & 1200 \\
\hline 9 & 19.1 & 12,500 & 16.5 & 600 \\
\hline 10 & 19.1 & 12,500 & 16.5 & 1200 \\
\hline 11 & 19.1 & 12,500 & 19.0 & 600 \\
\hline 12 & 19.1 & 12,500 & 19.0 & 1200 \\
\hline 13 & 19.1 & 25,000 & 16.5 & 600 \\
\hline 14 & 19.1 & 25,000 & 16.5 & 1200 \\
\hline 15 & 19.1 & 25,000 & 19.0 & 600 \\
\hline 16 & 19.1 & 25,000 & 19.0 & 1200 \\
\hline
\end{tabular}

The results from these runs are summarized in Table 41. A shear vane at 7' was used to measure the shear stress in this study. 
Table 41: Four Factor Test Results, $230 \mu \mathrm{m}$ Coke

\begin{tabular}{|c|c|c|c|c|c|c|c|c|}
\hline Run & $\begin{array}{c}\text { Riser } \\
\text { Flow } \\
\text { VR } \\
\text { ft } / \text { sec } \\
\end{array}$ & $\begin{array}{c}\text { Solids } \\
\text { Circulation } \\
\text { Rate } \\
\text { MS } \\
\underline{\text { lb/hr }}\end{array}$ & $\begin{array}{c}\text { Standpipe } \\
\text { Height } \\
\text { HSP } \\
\text { ft }\end{array}$ & $\begin{array}{c}\text { Loopseal } \\
\text { Flow } \\
\text { FLPSL } \\
\underline{\text { scfh }}\end{array}$ & $\begin{array}{c}-2 * \text { Shear } \\
\text { Stress/R } \\
\underline{\text { lb/ftt }}\end{array}$ & $\begin{array}{c}-\Delta \mathbf{P}_{\mathrm{g}} / \mathbf{L} \\
\mathbf{l b} / \mathbf{f t}^{2}\end{array}$ & $\begin{array}{c}-\Delta \mathbf{P}_{s} / \mathbf{L} \\
\mathbf{l b} / \mathbf{f t} \mathbf{t}^{2}\end{array}$ & Comments \\
\hline 1 & 15.61 & 12,604 & 16.5 & 601.82 & 5.62 & $\overline{33.48}$ & 14.90 & \\
\hline 2 & 15.82 & 12,460 & 16.5 & 1201.29 & 7.38 & 27.90 & 18.73 & \\
\hline 3 & 15.80 & 12,569 & 19 & 597.92 & 9.18 & 27.21 & 17.61 & \\
\hline 4 & 15.95 & 12,480 & 19 & 1202.71 & 10.68 & 20.67 & 22.65 & \\
\hline 5 & 15.77 & 24,406 & 16.5 & 600.47 & 0.12 & 46.73 & 7.14 & vane tangled? \\
\hline 6 & 15.65 & 25,414 & 16.5 & 1200.85 & 0.87 & 49.45 & 3.68 & vane tangled? \\
\hline 7 & 15.94 & 25,090 & 19 & 603.21 & 6.32 & 32.71 & 14.97 & $\begin{array}{l}7.5 \text { ' } 40 \mathrm{scfh}, \\
\text { slugging }\end{array}$ \\
\hline 8 & 16.07 & 24,059 & 19 & 1201.05 & 1.68 & 39.11 & 13.21 & $\begin{array}{l}\text { vane tangled? } \\
\text { slugging }\end{array}$ \\
\hline 9 & 19.13 & 12,464 & 16.5 & 601.68 & 9.26 & 25.51 & 19.22 & \\
\hline 10 & 19.30 & 12,529 & 16.5 & 1201.34 & 6.07 & 23.89 & 24.04 & \\
\hline 11 & 19.15 & 12,629 & 19 & 599.22 & 7.70 & 21.86 & 24.44 & \\
\hline 12 & 19.38 & 12,691 & 19 & 1200.32 & 7.30 & 14.19 & 32.51 & vane tangled? \\
\hline 13 & 18.84 & 24,693 & 16.5 & 603.02 & 4.16 & 37.52 & 12.32 & \\
\hline 14 & 19.19 & 24,254 & 16.5 & 1203.01 & 4.02 & 25.98 & 24.00 & $7.5^{\prime} 40 \mathrm{scfh}$ \\
\hline 15 & 18.95 & 25,067 & 19 & 594.60 & 4.29 & 38.16 & 11.55 & $\begin{array}{l}7.5^{\prime} 40 \mathrm{scfh}, \\
\text { SP B } 200 \mathrm{scff}\end{array}$ \\
\hline 16 & 19.05 & 25,373 & 19 & 1205.44 & 5.48 & 30.87 & 17.65 & $7.5^{\prime} 40 \mathrm{scfh}$ \\
\hline
\end{tabular}

Figures 88 through 90 illustrate these results graphically. Notice that the standpipe bed height is represented as Hsp.

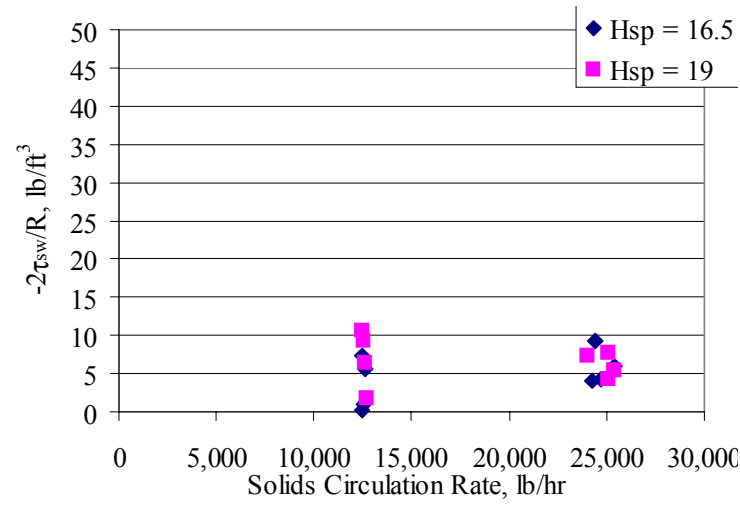

Figure 88: Shear Stress $\left(-2 \tau_{\mathrm{sw}} / \mathbf{R}\right)$ results of the Four Factor Test, $230 \mu \mathrm{m}$ Coke

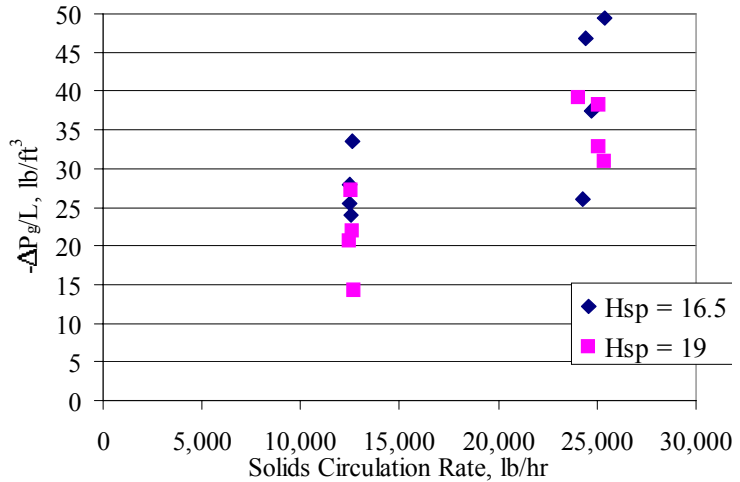

Figure 89: Gas Pressure Drop $\left(-\Delta \mathbf{P}_{\mathrm{g}} / \mathrm{L}\right)$ Results of the Four Factor Test, $230 \mu \mathrm{m}$ Coke 


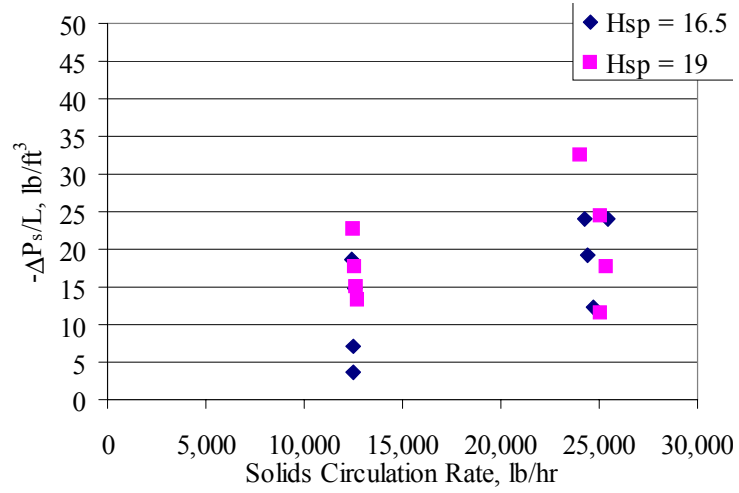

Figure 90: Solids Pressure $\left(-\Delta \mathbf{P}_{\mathrm{s}} / \mathrm{L}\right)$ Length Results of the Four Factor Test, $230 \mu \mathrm{m}$ Coke

A type I sum of squares analyses was applied to the three dependent variables listed in Table 41. Table 42 describes the results for the shear stress component of the momentum balance.

Table 42: ANOVA of Four Factor Test for Shear Stress $\left(-2 \tau_{\mathrm{sw}} / \mathrm{R}\right), 230 \mu \mathrm{m}$ Coke

Tests of Between-Subjects Effects

Dependent Variable: Shear Stress Component

\begin{tabular}{|c|c|c|c|c|c|c|c|c|}
\hline Source & $\begin{array}{l}\text { Type I } \\
\text { Sum of } \\
\text { Squares }\end{array}$ & df & $\begin{array}{l}\text { Mean } \\
\text { Square }\end{array}$ & $F$ & Sig. & $\begin{array}{c}\text { Eta } \\
\text { Squared }\end{array}$ & $\begin{array}{l}\text { Noncent. } \\
\text { Parameter }\end{array}$ & $\begin{array}{c}\text { Observed } \\
\text { Power }^{\mathrm{a}}\end{array}$ \\
\hline $\begin{array}{l}\text { Corrected } \\
\text { Model }\end{array}$ & $118.799^{b}$ & 10 & 11.880 & 3.229 & .104 & .866 & 32.292 & .499 \\
\hline Intercept & 507.915 & 1 & 507.915 & 138.063 & .000 & .965 & 138.063 & 1.000 \\
\hline VR & 2.578 & 1 & 2.578 & .701 & .441 & .123 & .701 & .106 \\
\hline MS & 82.073 & 1 & 82.073 & 22.309 & .005 & .817 & 22.309 & .961 \\
\hline HSP & 14.290 & 1 & 14.290 & 3.884 & .106 & .437 & 3.884 & .360 \\
\hline FLPSL & .631 & 1 & .631 & .172 & .696 & .033 & .172 & .063 \\
\hline $\mathrm{VR} * \mathrm{MS}$ & 8.235 & 1 & 8.235 & 2.238 & .195 & .309 & 2.238 & .231 \\
\hline VR * HSP & 9.961 & 1 & 9.961 & 2.708 & .161 & .351 & 2.708 & .268 \\
\hline $\begin{array}{l}\text { VR * } \\
\text { FLPSL }\end{array}$ & .229 & 1 & .229 & .062 & .813 & .012 & .062 & .055 \\
\hline $\mathrm{MS}{ }^{*} \mathrm{HSP}$ & .269 & 1 & .269 & .073 & .798 & .014 & .073 & .056 \\
\hline $\begin{array}{l}\text { MS * } \\
\text { FLPSL }\end{array}$ & .390 & 1 & .390 & .106 & .758 & .021 & .106 & .058 \\
\hline $\begin{array}{l}\text { HSP * } \\
\text { FLPSL }\end{array}$ & .143 & 1 & .143 & .039 & .852 & .008 & .039 & .053 \\
\hline Error & 18.394 & 5 & 3.679 & & & & & \\
\hline Total & 645.108 & 16 & & & & & & \\
\hline $\begin{array}{l}\text { Corrected } \\
\text { Total }\end{array}$ & 137.193 & 15 & & & & & & \\
\hline
\end{tabular}

a. Computed using alpha $=0.05$

b. $\mathrm{R}$ Squared $=.866$ (Adjusted $\mathrm{R}$ Squared $=.598)$

Section 3.5c discussed the information given in the ANOVA table in detail. From Table 42 mass circulation rate was the only significant main effect. The model explains 
$60 \%$ of the variability of shear stress and $40 \%$ of the variation is noise or unexplained variation.

These results are surprising, since solids circulation in Section 5.1 was not a significant variable. Keep in mind that in Section 5.1 the gas pressure drop per unit length was a controlled variable. In this experiment it was not controlled, and it may have changed with solids circulation rate, making solids circulation rate significant.

ANOVA results for the gas pressure drop $\left(-\Delta \mathrm{P}_{\mathrm{g}} / \mathrm{L}\right)$ in the control volume are in Table 43. As in the shear stress component model the solids circulation rate was significant. However, gas velocity in the riser was also significant, and the standpipe height was almost significant. Using the Eta squared values, the change in solids circulation had the largest impact on the gas pressure drop $\left(-\Delta \mathrm{P}_{\mathrm{g}} / \mathrm{L}\right)$ followed by the riser velocity and the standpipe height. None of the interactions were significant, and all of the interactions were almost equal in magnitude of importance according to Eta squared. From Figure 89, an increase in solids circulation rate resulted in an increase in gas pressure drop $\left(-\Delta \mathrm{P}_{\mathrm{g}} / \mathrm{L}\right)$ in the control volume. 


\section{Table 43: ANOVA of Four Factor Test for Gas Pressure Drop $\left(-\Delta \mathbf{P}_{\mathrm{g}} / \mathbf{L}\right)$ across the shear vane, $230 \mu \mathrm{m}$ Coke}

Tests of Between-Subjects Effects

Dependent Variable: Gas Pressure Drop Per Unit Length across the shear vane interval

\begin{tabular}{|c|c|c|c|c|c|c|c|c|}
\hline Source & $\begin{array}{l}\text { Type I } \\
\text { Sum of } \\
\text { Squares }\end{array}$ & $\mathrm{df}$ & $\begin{array}{c}\text { Mean } \\
\text { Square }\end{array}$ & $\mathrm{F}$ & Sig. & $\begin{array}{c}\text { Eta } \\
\text { Squared }\end{array}$ & $\begin{array}{l}\text { Noncent. } \\
\text { Parameter }\end{array}$ & $\begin{array}{c}\text { Observed } \\
\text { Power }^{\mathrm{a}}\end{array}$ \\
\hline $\begin{array}{l}\text { Corrected } \\
\text { Model }\end{array}$ & $1227.408^{b}$ & 10 & 122.741 & 4.659 & .052 & .903 & 46.591 & .666 \\
\hline Intercept & 15328.916 & 1 & 15328.916 & 581.868 & .000 & .991 & 581.868 & 1.000 \\
\hline VR & 219.632 & 1 & 219.632 & 8.337 & .034 & .625 & 8.337 & .640 \\
\hline MS & 699.867 & 1 & 699.867 & 26.566 & .004 & .842 & 26.566 & .981 \\
\hline HSP & 130.416 & 1 & 130.416 & 4.950 & .077 & .498 & 4.950 & .437 \\
\hline FLPSL & 60.528 & 1 & 60.528 & 2.298 & .190 & .315 & 2.298 & .235 \\
\hline $\mathrm{VR} * \mathrm{MS}$ & 8.497 & 1 & 8.497 & .323 & .595 & .061 & .323 & .075 \\
\hline VR * HSP & 56.400 & 1 & 56.400 & 2.141 & .203 & .300 & 2.141 & .223 \\
\hline $\begin{array}{l}\text { VR * } \\
\text { FLPSL }\end{array}$ & 39.438 & 1 & 39.438 & 1.497 & .276 & .230 & 1.497 & .170 \\
\hline $\mathrm{MS} * \mathrm{HSP}$ & 4.020 & 1 & 4.020 & .153 & .712 & .030 & .153 & .062 \\
\hline $\begin{array}{l}\text { MS * } \\
\text { FLPSL }\end{array}$ & 8.556 & 1 & 8.556 & .325 & .593 & .061 & .325 & .076 \\
\hline $\begin{array}{l}\text { HSP * } \\
\text { FLPSL }\end{array}$ & $5.290 \mathrm{E}-02$ & 1 & $5.290 \mathrm{E}-02$ & .002 & .966 & .000 & .002 & .050 \\
\hline Error & 131.722 & 5 & 26.344 & & & & & \\
\hline Total & 16688.046 & 16 & & & & & & \\
\hline $\begin{array}{l}\text { Corrected } \\
\text { Total }\end{array}$ & 1359.130 & 15 & & & & & & \\
\hline
\end{tabular}

a. Computed using alpha $=0.05$

b. R Squared $=.903$ (Adjusted R Squared $=.709)$

ANOVA results for solids pressure drop $\left(-\Delta \mathrm{P}_{\mathrm{s}} / \mathrm{L}\right)$ in the control volume are in Table 44. Similarly to the gas pressure drop $\left(-\Delta \mathrm{P}_{\mathrm{g}} / \mathrm{L}\right)$ across the shear vane model the riser gas velocity and solids circulation main effects were significant for the solids pressure drop $\left(-\Delta \mathrm{P}_{\mathrm{s}} / \mathrm{L}\right)$ model, and were almost equal in magnitude of importance according to Eta squared. From Figure 90, an increase in solids circulation rate resulted in a decrease in solids pressure $\left(-\Delta \mathrm{P}_{\mathrm{s}} / \mathrm{L}\right)$ in the control volume. 
Table 44: ANOVA of Four Factor Test for Solids Pressure Drop $\left(-\Delta \mathbf{P}_{s} / L\right), 230 \mu \mathrm{m}$ Coke

Tests of Between-Subjects Effects

Dependent Variable: Solids Pressure Drop Per Unit Length

\begin{tabular}{|c|c|c|c|c|c|c|c|c|}
\hline Source & $\begin{array}{l}\text { Type I } \\
\text { Sum of } \\
\text { Squares }\end{array}$ & df & $\begin{array}{c}\text { Mean } \\
\text { Square } \\
\end{array}$ & $\mathrm{F}$ & Sig. & $\begin{array}{c}\text { Eta } \\
\text { Squared } \\
\end{array}$ & $\begin{array}{c}\text { Noncent. } \\
\text { Parameter }\end{array}$ & $\begin{array}{c}\text { Observed } \\
\text { Power }^{\mathrm{a}} \\
\end{array}$ \\
\hline $\begin{array}{l}\text { Corrected } \\
\text { Model }\end{array}$ & $685.488^{b}$ & 10 & 68.549 & 3.563 & .087 & .877 & 35.629 & .542 \\
\hline Intercept & 4852.186 & 1 & 4852.186 & 252.194 & .000 & .981 & 252.194 & 1.000 \\
\hline VR & 174.533 & 1 & 174.533 & 9.071 & .030 & .645 & 9.071 & .675 \\
\hline MS & 302.685 & 1 & 302.685 & 15.732 & .011 & .759 & 15.732 & .882 \\
\hline HSP & 58.382 & 1 & 58.382 & 3.034 & .142 & .378 & 3.034 & .294 \\
\hline FLPSL & 73.588 & 1 & 73.588 & 3.825 & .108 & .433 & 3.825 & .355 \\
\hline $\mathrm{VR} * \mathrm{MS}$ & 2.172E-03 & 1 & 2.172E-03 & .000 & .992 & .000 & .000 & .050 \\
\hline VR * HSP & 18.961 & 1 & 18.961 & .985 & .366 & .165 & .985 & .129 \\
\hline $\begin{array}{l}\text { VR * } \\
\text { FLPSL }\end{array}$ & 45.659 & 1 & 45.659 & 2.373 & .184 & .322 & 2.373 & .242 \\
\hline $\mathrm{MS}{ }^{*} \mathrm{HSP}$ & 6.380 & 1 & 6.380 & .332 & .590 & .062 & .332 & .076 \\
\hline $\begin{array}{l}\text { MS * } \\
\text { FLPSL }\end{array}$ & 5.278 & 1 & 5.278 & .274 & .623 & .052 & .274 & .072 \\
\hline $\begin{array}{l}\text { HSP * } \\
\text { FLPSL }\end{array}$ & 2.126E-02 & 1 & 2.126E-02 & .001 & .975 & .000 & .001 & .050 \\
\hline Error & 96.199 & 5 & 19.240 & & & & & \\
\hline Total & 5633.873 & 16 & & & & & & \\
\hline $\begin{array}{l}\text { Corrected } \\
\text { Total }\end{array}$ & 781.688 & 15 & & & & & & \\
\hline
\end{tabular}

a. Computed using alpha $=0.05$

b. $\mathrm{R}$ Squared $=.877$ (Adjusted R Squared $=.631)$

\section{3c The effect of Standpipe Aeration Rate, Riser Gas Velocity, and Fines Concentration}

At any time the balance of pressures determines this split in the system, and because the split is unknown, it is very difficult to determine the relative velocities in the standpipe. Because operational variables such as standpipe aeration rate and the riser gas velocity change the balance of pressures, they also have an effect on the relative velocity of solids and gases in the standpipe. The level of fines is also of interest, because fines have an impact on the solids volume fraction, which will also affect relative velocities.

A three-factor experiment was run to understand the effect of standpipe gas velocity, riser gas velocity and level of fines on shear stress. Table 45 lists the runs completed to understand these variables. 
Table 45: Standpipe Aeration Rate, Riser Gas Velocity and Fines Level Test Independent Variables

\begin{tabular}{|c|c|c|c|}
\hline$\underline{\text { Run }}$ & $\begin{array}{c}\text { Riser Gas Velocity } \\
\text { ft/sec }\end{array}$ & $\begin{array}{c}\text { Standpipe Gas Velocity } \\
\text { ft/sec }\end{array}$ & $\begin{array}{c}\text { Fines Level } \\
\underline{\text { Lb }} \\
\end{array}$ \\
\hline 1 & 17.5 & .099 & 0 \\
\hline 2 & 17.5 & .099 & 200 \\
\hline 3 & 17.5 & .155 & 0 \\
\hline 4 & 17.5 & .155 & 200 \\
\hline 5 & 22.5 & .099 & 0 \\
\hline 6 & 22.5 & .099 & 200 \\
\hline 7 & 22.5 & .155 & 0 \\
\hline 8 & 22.5 & .155 & 200 \\
\hline 9 & 17.5 & .099 & 0 \\
\hline 10 & 17.5 & .099 & 200 \\
\hline 11 & 17.5 & .155 & 0 \\
\hline 12 & 17.5 & .155 & 200 \\
\hline 13 & 22.5 & .099 & 0 \\
\hline 14 & 22.5 & .099 & 200 \\
\hline 15 & 22.5 & .155 & 0 \\
\hline 16 & 22.5 & .155 & 200 \\
\hline
\end{tabular}

The results from the independent variables are summarized in Table 46. Notice that the high level for fines was always reported as $200 \mathrm{lb}$. Throughout the test fines were separated out using the secondary cyclone. In an effort to maintain a constant level of fines, they were collected and returned to the system. The total inventory of the system was maintained as constant. This was done with the use of the initial standpipe height when the material was completely stored in the standpipe. When the system was operated with coarse material the mass of the solids was determined using the initial height of the standpipe with no circulation and the known bulk density of coarse material. Once the fines were mixed into the system, the standpipe height with no circulation was adjusted so that the same amount of mass was in the system as in the coarse material cases. The change in bulk density, which varied from 54 to $56 \mathrm{lb} / \mathrm{ft}^{3}$ from coarse to coarse mixed with fines, was considered. Eight dependent variables were considered and the results for the independent and dependent variables are summarized in Tables 46 through 48. A shear vane at 7' was used to measure the shear stress. 
Table 46: Standpipe Aeration Rate, Riser Gas Velocity and Fines Level Test Independent Variable Results, Coke

\begin{tabular}{|c|c|c|c|}
\hline$\underline{\text { Run }}$ & $\begin{array}{c}\text { Riser Gas Velocity } \\
\mathbf{f t} / \mathbf{s e c}\end{array}$ & $\begin{array}{c}\text { Standpipe Gas Velocity } \\
\mathbf{f t} / \mathbf{s e c}\end{array}$ & $\begin{array}{c}\text { Fines Level } \\
\mathbf{\mathbf { l b }}\end{array}$ \\
\hline 1 & 17.519 & 0.098 & 0 \\
\hline 2 & 17.548 & 0.100 & 200 \\
\hline 3 & 17.479 & 0.153 & 0 \\
\hline 4 & 17.487 & 0.154 & 200 \\
\hline 5 & 22.538 & 0.099 & 0 \\
\hline 6 & 22.461 & 0.099 & 200 \\
\hline 7 & 22.358 & 0.157 & 0 \\
\hline 8 & 22.510 & 0.155 & 0 \\
\hline 9 & 17.517 & 0.099 & 200 \\
\hline 10 & 17.430 & 0.099 & 0 \\
\hline 11 & 17.510 & 0.153 & 200 \\
\hline 12 & 17.528 & 0.154 & 0 \\
\hline 13 & 22.419 & 0.099 & 0 \\
\hline 14 & 22.464 & 0.099 & 200 \\
\hline 15 & 22.458 & 0.157 & \\
\hline 16 & 22.483 & 0.154 & 0 \\
\hline
\end{tabular}

Table 47: Standpipe Aeration Rate, Riser Gas Velocity and Fines Level Test Dependent Variable Results, Coke

\begin{tabular}{|c|c|c|c|c|c|c|}
\hline$\underline{\text { Run }}$ & $\begin{array}{c}-2 \tau_{\mathrm{sw}} / \mathbf{R} \\
\underline{\mathbf{l b} / \mathbf{f t}^{3}} \\
\end{array}$ & $\begin{array}{c}\left(-\Delta \mathbf{P}_{\mathbf{g}} / \mathbf{L}\right)_{\text {Shear Vane }} \\
\underline{\underline{\mathbf{b}} / \mathbf{f t}^{3}} \\
\end{array}$ & $\begin{array}{l}-\Delta \mathbf{P}_{s} / \mathbf{L} \\
\underline{\mathbf{l b} / \mathbf{f t}^{3}} \\
\end{array}$ & $\begin{array}{c}\text { Solids } \\
\text { Circulation } \\
\underline{\text { lb/hr }} \\
\end{array}$ & $\begin{array}{c}\text { Standpipe } \\
\text { Height } \\
\text { ft }\end{array}$ & $\begin{array}{c}\left(-\Delta \mathbf{P}_{\mathbf{g}}\right)_{\text {Riser }} \\
\text { psid }\end{array}$ \\
\hline 1 & 8.560 & 11.515 & 34.949 & 22,262 & 27.7 & 0.875 \\
\hline 2 & 11.392 & 11.781 & 34.553 & 28,405 & 27.6 & 1.125 \\
\hline 3 & 5.920 & 21.222 & 28.745 & 30,409 & 23.5 & 1.635 \\
\hline 4 & 5.773 & 28.602 & 23.441 & 39,627 & 23.4 & 2.007 \\
\hline 5 & 9.373 & 10.310 & 36.240 & 23,939 & 28.5 & 0.649 \\
\hline 6 & 11.059 & 10.158 & 35.647 & 28,790 & 28.4 & 0.863 \\
\hline 7 & 8.142 & 17.790 & 28.195 & 32,521 & 25.5 & 1.102 \\
\hline 8 & 7.735 & 23.848 & 24.977 & 41,636 & 26.2 & 1.379 \\
\hline 9 & 8.726 & 11.612 & 34.712 & 22,219 & 27 & 0.903 \\
\hline 10 & 9.671 & 12.260 & 37.599 & 28,734 & 27 & 1.138 \\
\hline 11 & 7.070 & 21.499 & 27.054 & 29,686 & 23.8 & 1.657 \\
\hline 12 & 6.733 & 28.639 & 22.061 & 40,572 & 23.4 & 1.999 \\
\hline 13 & 10.640 & 10.984 & 33.794 & 23,198 & 28.4 & 0.644 \\
\hline 14 & 10.578 & 10.308 & 36.917 & 29,440 & 28.2 & 0.889 \\
\hline 15 & 7.482 & 17.583 & 29.731 & 33,590 & 25.5 & 1.089 \\
\hline 16 & 8.772 & 23.533 & 24.965 & 42,982 & 28.2 & 1.380 \\
\hline
\end{tabular}


Table 48: Standpipe Aeration Rate, Riser Gas Velocity and Fines Level Test Dependent Variable Results-continued, Coke

\begin{tabular}{|c|c|c|c|}
\hline Run & $\begin{array}{c}\text { Bulk } \\
\text { Density } \\
\rho_{\mathbf{b}} \\
\mathbf{l} \mathbf{b} / \mathbf{f t}^{3}\end{array}$ & $\begin{array}{c}\text { Average } \\
\text { Particle } \\
\text { Diameter } \\
\mathbf{d}_{\mathbf{p}} \\
\mu \mathbf{m}\end{array}$ & $\begin{array}{c}\text { Standard } \\
\text { deviation } \\
\text { of } d_{p} \\
\mu m\end{array}$ \\
\hline$\overline{11}$ & $5 \overline{55.023}$ & 253.08 & 9.515 \\
\hline 2 & 57.727 & 197.45 & 5.469 \\
\hline 3 & 55.887 & 261.33 & 9.492 \\
\hline 4 & 57.817 & 211.88 & 4.170 \\
\hline 5 & 55.923 & 241.78 & 6.096 \\
\hline 6 & 56.863 & 205.91 & 18.860 \\
\hline 7 & 54.127 & 262.31 & 8.647 \\
\hline 8 & 56.560 & 211.61 & 23.363 \\
\hline 9 & 55.050 & 258.39 & 4.825 \\
\hline 10 & 59.530 & 212.56 & 17.180 \\
\hline 11 & 55.623 & 257.34 & 3.222 \\
\hline 12 & 57.433 & 230.13 & 7.896 \\
\hline 13 & 55.417 & 252.67 & 8.062 \\
\hline 14 & 57.803 & 221.49 & 22.704 \\
\hline 15 & 54.797 & 274.12 & 3.478 \\
\hline 16 & 57.270 & 213.52 & 10.147 \\
\hline
\end{tabular}

Figures 91 through 94 illustrate these results graphically.

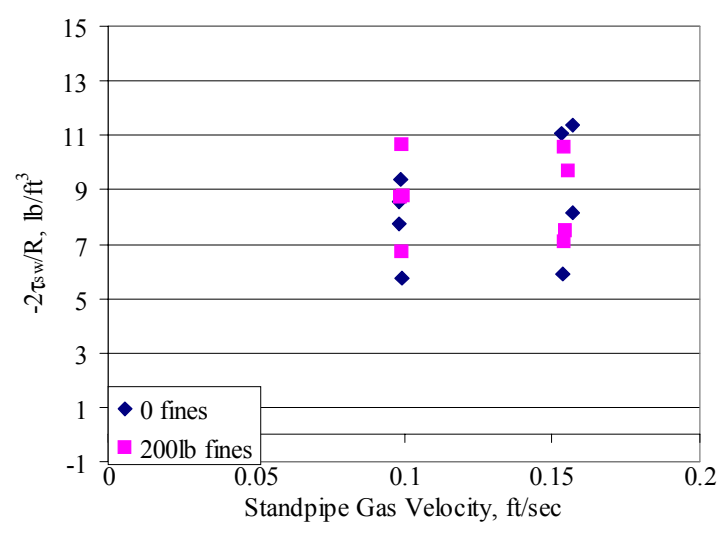

Figure 91: Shear Stress Component Results of 3 Factor Factorial, Riser Gas Velocity, Standpipe Gas Velocity, and Fines Concentration, Coke

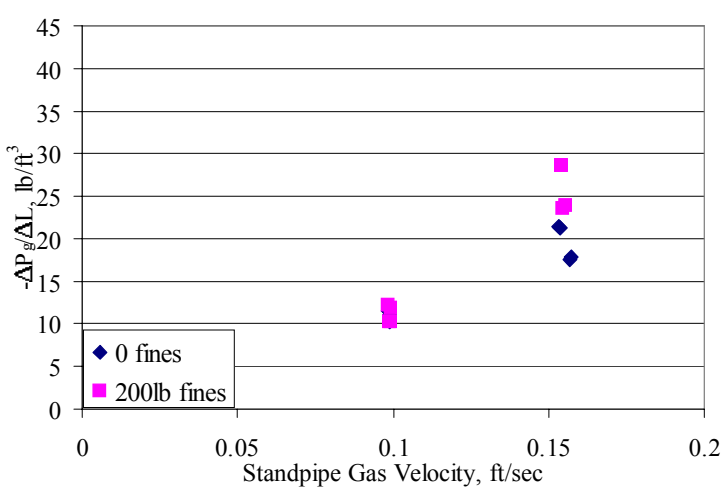

Figure 92: Gas Pressure Drop $\left(-\Delta \mathbf{P}_{\mathrm{g}} / \mathrm{L}\right)$ Results of 3 Factor Factorial, Riser Gas Velocity, Standpipe Gas Velocity, and Fines Concentration, Coke 


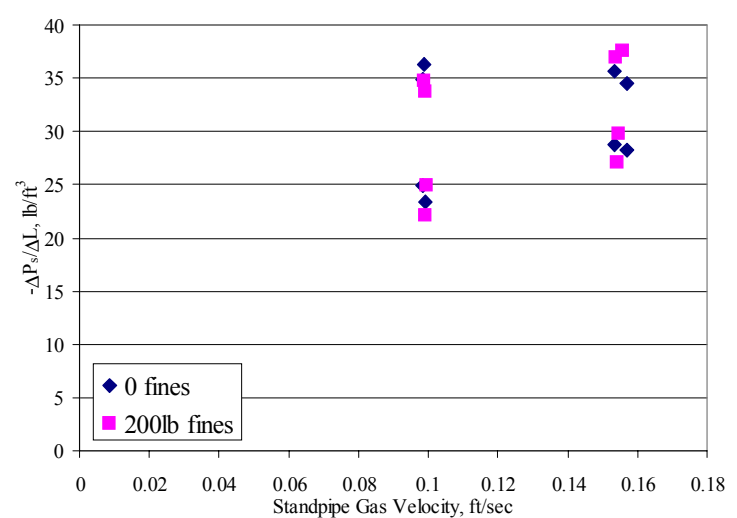

Figure 93: Solids Pressure Drop $\left(-\Delta \mathbf{P}_{s} / \mathbf{L}\right)$ Results of 3 Factor Factorial, Riser Gas Velocity, Standpipe Gas Velocity, and fines Concentration, Coke

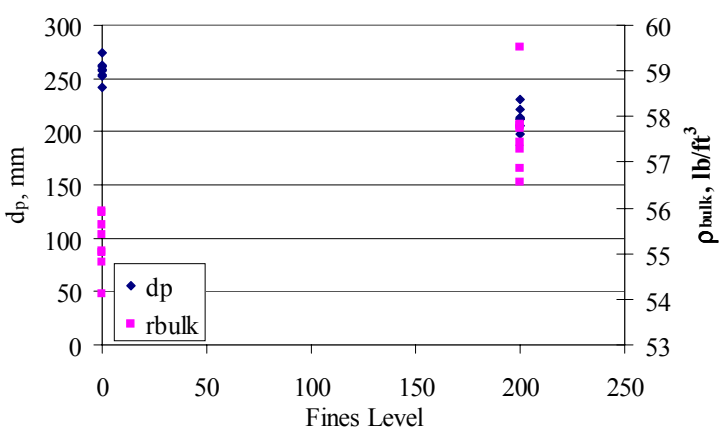

Figure 94: Bed Material Property Results of 3 Factor Factorial, Riser Gas Velocity, Standpipe Gas Velocity, and fines Concentration, Coke

A type I sum of squares analyses was applied to the nine dependent variables listed in Tables 47 and 48. The ANOVA results for the shear stress component are listed in Table 49. Notice that riser gas velocity, standpipe gas velocity, and fines concentration are denoted as VR and FM, and FINES respectively.

Table 49: ANOVA of Fines Test for Shear Stress Component, Coke

Tests of Between-Subjects Effects

\begin{tabular}{|c|c|c|c|c|c|c|c|c|}
\hline Source & $\begin{array}{l}\text { Type I } \\
\text { Sum of } \\
\text { Squares }\end{array}$ & $\mathrm{df}$ & $\begin{array}{c}\text { Mean } \\
\text { Square }\end{array}$ & $F$ & Sig. & $\begin{array}{c}\text { Eta } \\
\text { Squared }\end{array}$ & $\begin{array}{l}\text { Noncent. } \\
\text { Parameter }\end{array}$ & $\begin{array}{c}\text { Observed } \\
\text { Power }^{\mathrm{a}} \\
\end{array}$ \\
\hline $\begin{array}{l}\text { Corrected } \\
\text { Model }\end{array}$ & $41.810^{b}$ & 5 & 8.362 & 16.385 & .000 & .891 & 81.926 & 1.000 \\
\hline Intercept & 1183.771 & 1 & 1183.771 & 2319.599 & .000 & .996 & 2319.599 & 1.000 \\
\hline VR & 6.171 & 1 & 6.171 & 12.092 & .006 & .547 & 12.092 & .879 \\
\hline FM & 31.277 & 1 & 31.277 & 61.288 & .000 & .860 & 61.288 & 1.000 \\
\hline FINES & 2.103 & 1 & 2.103 & 4.121 & .070 & .292 & 4.121 & .450 \\
\hline$V R{ }^{*} F M$ & .695 & 1 & .695 & 1.363 & .270 & .120 & 1.363 & .185 \\
\hline $\begin{array}{l}\text { FM * } \\
\text { FINES }\end{array}$ & 1.563 & 1 & 1.563 & 3.063 & .111 & .234 & 3.063 & .353 \\
\hline Error & 5.103 & 10 & .510 & & & & & \\
\hline Total & 1230.684 & 16 & & & & & & \\
\hline $\begin{array}{l}\text { Corrected } \\
\text { Total }\end{array}$ & 46.913 & 15 & & & & & & \\
\hline
\end{tabular}

a. Computed using alpha $=0.05$

b. R Squared $=.891$ (Adjusted R Squared $=.837$ )

Section 3.5c discussed the information given in the ANOVA table in detail. From Table 49, riser gas velocity and standpipe gas velocity were significant, and fines concentration was very close to being significant. No interactions between independent 
variables were significant. Standpipe gas velocity had the largest eta-squared which meant that changes in standpipe gas velocity resulted in the largest changes of shear stress. The model explained $84 \%$ of the variability of shear stress and $16 \%$ of the variation was noise or unexplained variation.

ANOVA results for all of the dependent variables are summarized in Table 50 and 51. All of the models for the independent variables were very strong, above 0.89 except for the shear stress model. However, $\mathrm{R}^{2}$ value of 0.837 for the shear stress component was very high compared to other tests. In all cases standpipe velocity was significant. Level of fines was significant for all variables except for the standpipe height. None of the interaction effects were significant for the shear stress model. However, all of the interaction effects were significant for the gas pressure drop $\left(-\Delta \mathrm{P}_{\mathrm{s}} / \mathrm{L}\right)$.

Segregation in the riser may have been an indication of the poor fit for shear stress. Further, shear stress was the last variable to come to steady state. It may have not been at steady state for all of the conditions in the fines test. 
Table 50: ANOVA of Fines Test for Dependent Variables, Coke

\begin{tabular}{|c|c|c|c|c|c|}
\hline$\underline{\text { Statistic }}$ & $\begin{array}{c}-2 \tau_{\mathrm{sw}} / \mathbf{R} \\
\underline{\mathbf{l b} / \mathbf{f t}^{3}}\end{array}$ & $\begin{array}{c}-\Delta \mathbf{P}_{\mathbf{g}} / \mathbf{L} \\
\text { shear vane } \\
\underline{\mathbf{l b} / \mathbf{f t}^{\mathbf{3}}}\end{array}$ & $\begin{array}{l}-\Delta \mathbf{P}_{\mathbf{s}} / \mathbf{L} \\
\underline{\mathbf{l b} / \mathbf{f t}^{3}}\end{array}$ & $\begin{array}{c}\text { Solids } \\
\text { Circulation, } \\
\underline{\mathbf{l b} / \mathbf{h r}}\end{array}$ & $\begin{array}{c}\text { Standpipe } \\
\text { Height, } \\
\text { ft }\end{array}$ \\
\hline Mean Square, VR & 1.537 & 31.978 & 3.379 & $12, \overline{570,217}$ & 15.016 \\
\hline Mean Square, FM & 7.788 & 549.762 & $\begin{array}{c}353.82 \\
5\end{array}$ & $4.41 \mathrm{E}+08$ & 33.931 \\
\hline Mean Square, Fines & 0.524 & 44.268 & 10.986 & $2.43 \mathrm{E}+08$ & 0.391 \\
\hline $\begin{array}{l}\text { Mean Square, } \\
\text { VR*FM }\end{array}$ & 0.173 & 8.704 & 2.090 & $2,796,763.0$ & 3.151 \\
\hline $\begin{array}{l}\text { Mean Square, } \\
\text { VR*FINES }\end{array}$ & & 1.131 & & $624,433.32$ & 0.856 \\
\hline $\begin{array}{l}\text { Mean Square, } \\
\text { FM*FINES }\end{array}$ & 0.389 & 43.699 & 33.944 & $13,799,578$ & 0.681 \\
\hline $\mathrm{F}, \mathrm{VR}$ & 12.092 & 571.076 & 2.662 & 41.492 & 38.115 \\
\hline $\mathrm{F}, \mathrm{FM}$ & 61.288 & $9,817.815$ & $\begin{array}{c}278.66 \\
9\end{array}$ & $1,456.861$ & 86.127 \\
\hline F, Fines & 4.121 & 790.556 & 8.652 & 802.310 & 0.992 \\
\hline $\mathrm{F}, \mathrm{VR} * \mathrm{FM}$ & 1.363 & 155.447 & 1.646 & 9.232 & 7.997 \\
\hline F, VR*FINES & & 20.196 & & 2.061 & 2.172 \\
\hline F, FM*FINES & 3.063 & 780.395 & 26.734 & 45.550 & 1.728 \\
\hline Sig, VR & 0.006 & 0.000 & 0.134 & 0.000 & 0.000 \\
\hline Sig, FM & 0.000 & 0.000 & 0.000 & 0.000 & 0.000 \\
\hline Sig, FINES & 0.070 & 0.000 & 0.015 & 0.000 & 0.345 \\
\hline Sig, VR*FM & 0.270 & 0.000 & 0.228 & 0.014 & 0.020 \\
\hline Sig, VR*FINES & & 0.002 & & 0.185 & 0.175 \\
\hline Sig, FM*FINES & 0.111 & 0.000 & 0.000 & 0.000 & 0.221 \\
\hline Eta Squared, VR & 0.547 & 0.984 & 0.210 & 0.822 & 0.809 \\
\hline Eta Squared, FM & 0.860 & 0.999 & 0.965 & 0.994 & 0.905 \\
\hline Eta Squared, FINES & 0.292 & 0.989 & 0.464 & 0.989 & 0.099 \\
\hline $\begin{array}{l}\text { Eta Squared, } \\
\text { VR*FM }\end{array}$ & 0.120 & 0.945 & 0.141 & 0.506 & 0.471 \\
\hline $\begin{array}{l}\text { Eta Squared, } \\
\text { VR*FINES }\end{array}$ & & 0.692 & & 0.186 & 0.194 \\
\hline $\begin{array}{l}\text { Eta Squared, } \\
\text { FM*FINES }\end{array}$ & 0.234 & 0.989 & 0.728 & 0.835 & 0.161 \\
\hline Adjusted R squared & 0.837 & 0.999 & 0.954 & 0.994 & 0.897 \\
\hline
\end{tabular}


Table 51: ANOVA of Fines Test for Dependent Variables- Continued, Coke

\begin{tabular}{|c|c|c|c|c|}
\hline$\underline{\text { Statistic }}$ & $\begin{array}{r}D_{p} \\
\mu \mathrm{m} \\
\end{array}$ & $\begin{array}{c}\text { St. Dev } \\
d_{p} \\
\underline{\mu m}\end{array}$ & $\begin{array}{c}\rho_{b} \\
l \mathbf{l b} / \mathbf{f t}^{3}\end{array}$ & $\begin{array}{c}\left(-\Delta \mathbf{P}_{\mathbf{g}}\right)_{\text {Riser }} \\
\text { psid }\end{array}$ \\
\hline Mean Square, VR & 0.0995 & 97.963 & 1.776 & 0.699 \\
\hline Mean Square, FM & 389.13 & 31.068 & 0.914 & 1.644 \\
\hline Mean Square, Fines & 7,942 & 199.168 & 22.936 & 0.310 \\
\hline Mean Square, VR*FM & & & & 0.114 \\
\hline $\begin{array}{c}\text { Mean Square, } \\
\text { VR*FINES }\end{array}$ & & 105.723 & & 0.00186 \\
\hline $\begin{array}{l}\text { Mean Square, } \\
\text { FM*FINES }\end{array}$ & & & & 0.00711 \\
\hline $\mathrm{F}, \mathrm{VR}$ & 0.001 & 4.664 & 3.890 & 3,045 \\
\hline $\mathrm{F}, \mathrm{FM}$ & 5.325 & 1.479 & 2.002 & 7,252 \\
\hline F, Fines & 108.68 & 9.483 & 50.248 & 1,349 \\
\hline $\mathrm{F}, \mathrm{VR} * \mathrm{FM}$ & & & & 497 \\
\hline F, VR*FINES & & 5.034 & & 8.09 \\
\hline F, FM*FINES & & & & 30.97 \\
\hline Sig, VR & 0.971 & 0.054 & 0.072 & 0.000 \\
\hline Sig, FM & 0.040 & 0.249 & 0.183 & 0.000 \\
\hline Sig, FINES & 0.000 & 0.010 & 0.000 & 0.000 \\
\hline Sig, VR*FM & & & & 0.000 \\
\hline Sig, VR*FINES & & 0.046 & & 0.019 \\
\hline Sig, FM*FINES & & & & 0.000 \\
\hline Eta Squared, VR & 0.000 & 0.298 & 0.245 & 0.997 \\
\hline Eta Squared, FM & 0.307 & 0.119 & 0.143 & 0.999 \\
\hline Eta Squared, FINES & 0.901 & 0.463 & 0.807 & 0.993 \\
\hline Eta Squared, VR*FM & & & & 0.982 \\
\hline $\begin{array}{c}\text { Eta Squared, } \\
\text { VR*FINES }\end{array}$ & & 0.314 & & 0.473 \\
\hline $\begin{array}{c}\text { Eta Squared, } \\
\text { FM*FINES }\end{array}$ & & & & 0.775 \\
\hline Adjusted R squared & 0.881 & 0.526 & 0.780 & 0.999 \\
\hline
\end{tabular}

Most of the variables in Table 51 are related to intended changes when adding fines to the system. Although the models had lower R squared values, they indicated that the addition of fines was a significant variable for all three dependent variables. This suggested that effect of changing the average particle diameter or fines content in the bed was accomplished. 
5.3d The Effect of Location of Standpipe Move Air, Aeration at 20.8 feet, and

\section{Direction of Ramp}

A study was conducted to understand the effects of the location of the move air on the momentum balance components. In section 5.2, evidence of hysteresis was discussed. Furthermore, a difference between the behavior of the momentum balance components for aeration ramps with and without aeration at the very bottom of the standpipe was suggested. Mountziaris (1990) studied the effects of hysteresis on standpipe circulation. Hysteresis in this context means the effect of a condition may be dependent on the way you come to that condition. As a result, part of this experiment was to study the difference between ramping up to the desired move aeration and ramping down to it. Also, the aeration at 20.8 feet was tested to see if it could compress the bed below it. The experimental matrix is in Table 52 .

Table 52: Standpipe Aeration Location, Aeration at 20.8 feet, and Ramp Direction Test Matrix

\begin{tabular}{|c|c|c|c|c|}
\hline Standard & Run Order & $\begin{array}{c}\text { Location of } \\
\text { Move Aeration }\end{array}$ & $\begin{array}{c}\text { Aeration at } \\
\mathbf{2 0 . 8} \text { feet, } \\
\text { scfh }\end{array}$ & $\begin{array}{c}\text { Ramp } \\
\text { Direction }\end{array}$ \\
\hline 1 & 12 & $-0.8^{\prime}$ & 25 & increasing \\
\hline 2 & 11 & $-0.8^{\prime}$ & 25 & decreasing \\
\hline 3 & 4 & $-0.8^{\prime}$ & 50 & increasing \\
\hline 4 & 3 & $-0.8^{\prime}$ & 50 & decreasing \\
\hline 5 & 2 & $0.3^{\prime}$ & 25 & increasing \\
\hline 6 & 1 & $0.3^{\prime}$ & 25 & decreasing \\
\hline 7 & 8 & $0.3^{\prime}$ & 50 & increasing \\
\hline 8 & 7 & $0.3^{\prime}$ & 50 & decreasing \\
\hline 9 & 14 & $-0.8^{\prime}$ & 25 & increasing \\
\hline 10 & 13 & $-0.8^{\prime}$ & 25 & decreasing \\
\hline 11 & 16 & $-0.8^{\prime}$ & 50 & increasing \\
\hline 12 & 15 & $-0.8^{\prime}$ & 50 & decreasing \\
\hline 13 & 6 & $0.3^{\prime}$ & 25 & increasing \\
\hline 14 & 5 & $0.3^{\prime}$ & 25 & decreasing \\
\hline 15 & 10 & $0.3^{\prime}$ & 50 & increasing \\
\hline 16 & 9 & $0.3^{\prime}$ & 50 & decreasing \\
\hline
\end{tabular}

All of the tests in Table 52 were for a move air of $150 \mathrm{scfh}$. The way this aeration

was achieved was one of the variables studied, ramp direction. The location of the move air was another variable studied. The location of $0.3^{\prime}$ corresponded to the typical move air location in Figure 10, and the location of $-0.8^{\prime}$ corresponded to aeration at the bottom 
of the standpipe. For example, the first row in Table 52 corresponded to a condition in which the aeration at the bottom of the standpipe was set at 150 and the aeration at 0.3 ' was zero. Furthermore, this total aeration of 150 was achieved by ramping the aeration from 0 to $150 \mathrm{scfh}$. In contrast, the next condition was achieved by ramping the same aeration from 300 to $150 \mathrm{scfh}$. A strict regimen was used in that the steady states were taken holding this condition for exactly six minutes. This was done so the ramps could also be directly compared over the time domain. As a result, variables slow to reach steady state were less likely to provide reproducible results over up and down flow periods. The results for the dependent variables are in Table 53. A shear vane at 7' was used to measure the shear stress in this study.

Table 53: Standpipe Aeration Location, Aeration at 20.8', and Ramp Direction Dependent Variable Results, $230 \mu \mathrm{m}$ Coke

\begin{tabular}{|c|c|c|c|c|c|}
\hline Standard & $\begin{array}{c}-2 \tau_{\mathrm{sw}} / \mathbf{R} \\
\mathbf{l b} / \mathbf{f t}^{3}\end{array}$ & $\frac{-\Delta \mathbf{P}_{\mathrm{g}} / \Delta \mathbf{L}}{\mathbf{l b} / \mathbf{f t}^{3}}$ & $\frac{-\Delta \mathbf{P}_{s} / \Delta \mathbf{L}}{\mathbf{l b} / \mathbf{f t}^{3}}$ & $\begin{array}{c}\text { Standpipe } \\
\text { Height } \\
\text { ft }\end{array}$ & $\begin{array}{c}\text { Solids } \\
\text { Circulation } \\
\text { lb/hr }\end{array}$ \\
\hline 1 & $22 . \overline{134789}$ & 2.77 & 29.090295 & $2 \overline{7} .2$ & 19,079 \\
\hline 2 & 19.810634 & 3.12 & 31.222534 & 27 & 19,095 \\
\hline 3 & 15.598503 & 0.73 & 37.669617 & 27.3 & 19,413 \\
\hline 4 & 15.539647 & 0.57 & 37.894037 & 27.6 & 19,542 \\
\hline 5 & 12.839003 & 4.46 & 36.701641 & 27.4 & 20,096 \\
\hline 6 & 18.559469 & 1.79 & 33.648955 & 28.6 & 18,827 \\
\hline 7 & 14.188862 & 2.17 & 37.644838 & 27 & 20,510 \\
\hline 8 & 15.778635 & 2.25 & 35.971185 & 27.2 & 20,395 \\
\hline 9 & 22.439678 & 2.98 & 28.581934 & 27.1 & 19,282 \\
\hline 10 & 17.521493 & 1.97 & 34.505419 & 27.2 & 18,615 \\
\hline 11 & 16.900975 & 1.37 & 35.724473 & 26.9 & 20,295 \\
\hline 12 & 24.531632 & 0.97 & 28.498960 & 26.9 & 19,895 \\
\hline 13 & 14.603802 & 4.68 & 34.718898 & 27.2 & 19,839 \\
\hline 14 & 14.667025 & 4.20 & 35.136815 & 27.5 & 19,698 \\
\hline 15 & 23.933653 & 2.59 & 27.476795 & 27 & 20,520 \\
\hline 16 & 17.298615 & 2.19 & 34.509453 & 27 & 20,798 \\
\hline
\end{tabular}

The data in Table 53 is plotted in Figures 95 through 97. 


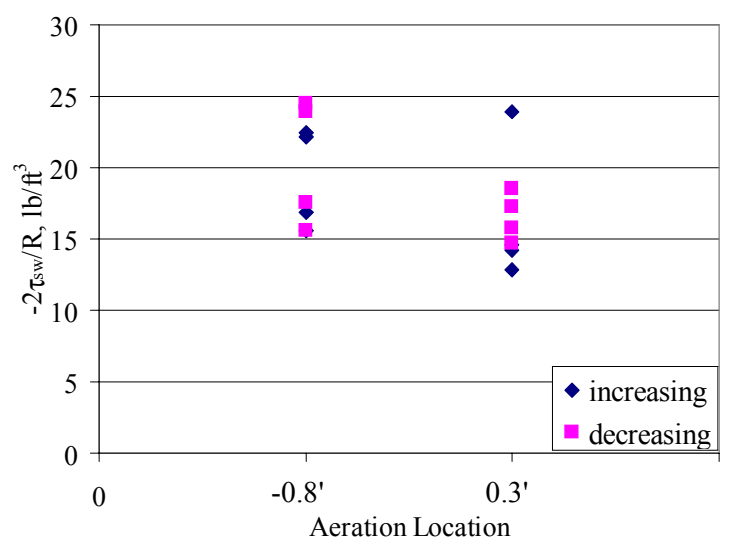

Figure 95: Results of Shear Stress Component for Hysteresis Test, $230 \mu \mathrm{m}$ Coke

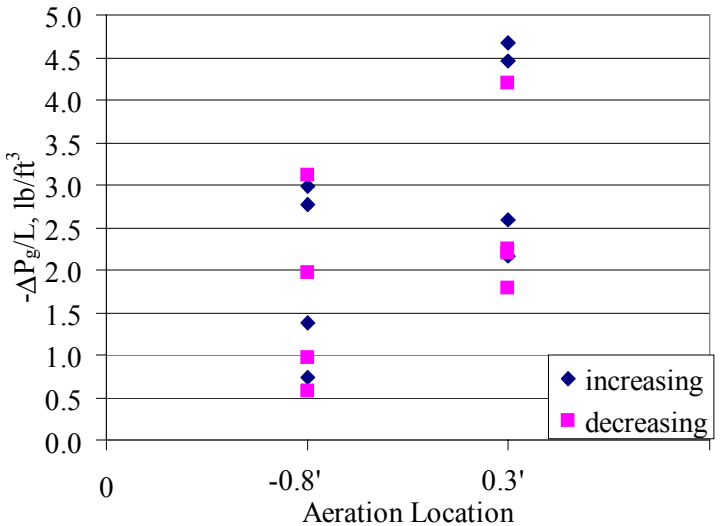

Figure 96: Results of Gas Pressure Drop Component for Hysteresis Test, $230 \mu \mathrm{m}$ Coke

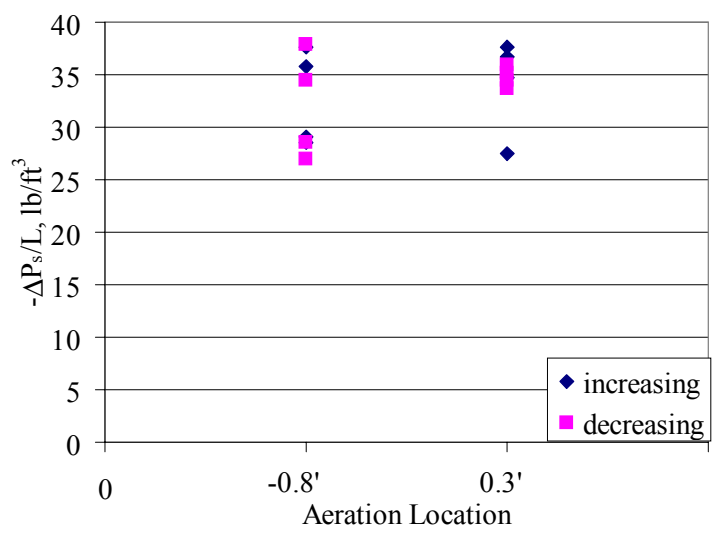

Figure 97: Results of Solids Pressure Drop Component for Hysteresis Test, $230 \mu \mathrm{m}$ Coke

A type I sum of squares analyses was applied to the five dependent variables listed in Table 53. The ANOVA results for the shear stress component are listed in Table 54. Notice that aeration location, aeration at the dipleg, and ramp direction are denoted as AERATLOC and DPLGAERA, and RAMPDIR respectively. 
Table 54: ANOVA Results of the Shear Stress Component of the Hysteresis Test, $230 \mu \mathrm{m}$ Coke

Tests of Between-Subjects Effects

Dependent Variable: Shear Stress Component

\begin{tabular}{|c|c|c|c|c|c|c|c|c|}
\hline Source & $\begin{array}{c}\text { Type I } \\
\text { Sum of } \\
\text { Squares }\end{array}$ & df & $\begin{array}{l}\text { Mean } \\
\text { Square }\end{array}$ & $\mathrm{F}$ & Sig. & $\begin{array}{c}\text { Eta } \\
\text { Squared }\end{array}$ & $\begin{array}{l}\text { Noncent. } \\
\text { Parameter }\end{array}$ & $\begin{array}{c}\text { Observed } \\
\text { Power }^{\mathrm{a}}\end{array}$ \\
\hline $\begin{array}{l}\text { Corrected } \\
\text { Model }\end{array}$ & $98.874^{\mathrm{b}}$ & 7 & 14.125 & 1.111 & .438 & .493 & 7.777 & .244 \\
\hline Intercept & 5124.642 & 1 & 5124.642 & 403.074 & .000 & .981 & 403.074 & 1.000 \\
\hline AERATLOC & 31.946 & 1 & 31.946 & 2.513 & .152 & .239 & 2.513 & .287 \\
\hline DPLGAERA & 8.920E-02 & 1 & 8.920E-02 & .007 & .935 & .001 & .007 & .051 \\
\hline RAMPDIR & 7.127E-02 & 1 & 7.127E-02 & .006 & .942 & .001 & .006 & .051 \\
\hline $\begin{array}{l}\text { AERATLOC } \\
\text { * } \\
\text { DPLGAERA }\end{array}$ & 24.667 & 1 & 24.667 & 1.940 & .201 & .195 & 1.940 & .233 \\
\hline $\begin{array}{l}\text { AERATLOC } \\
{ }^{*} \text { RAMPDIR }\end{array}$ & 1.045E-02 & 1 & 1.045E-02 & .001 & .978 & .000 & .001 & .050 \\
\hline $\begin{array}{l}\text { DPLGAERA } \\
\text { * RAMPDIR }\end{array}$ & .993 & 1 & .993 & .078 & .787 & .010 & .078 & .057 \\
\hline$\underset{*}{\text { AERATLOC }}$ & & & & & & & & \\
\hline $\begin{array}{l}\text { DPLGAERA } \\
\text { * RAMPDIR }\end{array}$ & 41.098 & 1 & 41.098 & 3.233 & .110 & .288 & 3.233 & .354 \\
\hline Error & 101.711 & 8 & 12.714 & & & & & \\
\hline Total & 5325.227 & 16 & & & & & & \\
\hline $\begin{array}{l}\text { Corrected } \\
\text { Total }\end{array}$ & 200.585 & 15 & & & & & & \\
\hline
\end{tabular}

a. Computed using alpha $=0.05$

b. $\mathrm{R}$ Squared $=.493$ (Adjusted R Squared $=.049$ )

Section 3.5c discussed the information given in the ANOVA table in detail. From Table 54, there were no significant variables, which was seen in Figure 95. The model explained $5 \%$ of the variability of shear stress. The shear stress component was not affected by any of the variables tested. Explanations for the lack of dependence could have been that the shear stress was not quite at steady state when the data was recorded. In Figure 98 the range of the shear stress component can be seen as well as how well the replicates repeated. 


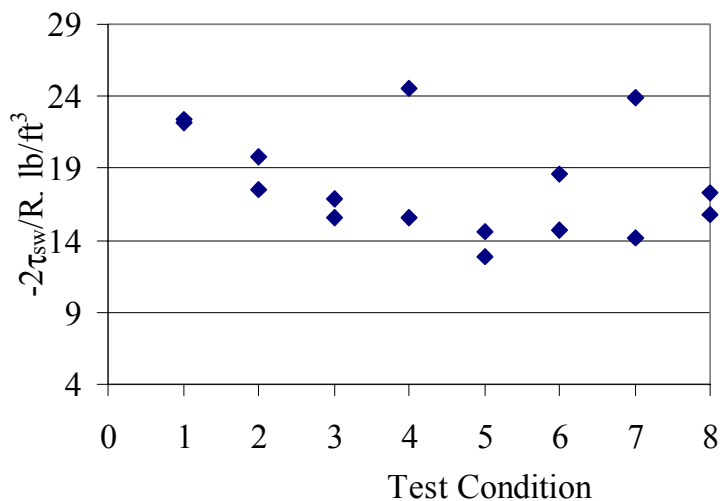

Figure 98: Comparison of Hysteresis Test Replicates, $230 \mu \mathrm{m}$ Coke

In Figure 98 the test condition corresponds to the eight replicated runs that are outlined in Table 52. For example, test condition number 3 in Figure 98 corresponds to standard number 3 and 11 in Table 52. Both have identical test conditions. From Figure 98 three of the replicates did not repeat well and the overall changes in the test were small compared to the differences in the replicates for conditions four and seven. There were no obvious reasons for the lack of repeatability for conditions four, six, and seven.

Already mentioned was the concern that shear stress was not at steady state for a number of the test conditions. It has been found that for several conditions the shear stress was not steady state. Figures 99 and 100 are examples of this for runs two and nine. These are plots of the shear stress component over time for the five-minute period over which the steady state was averaged.

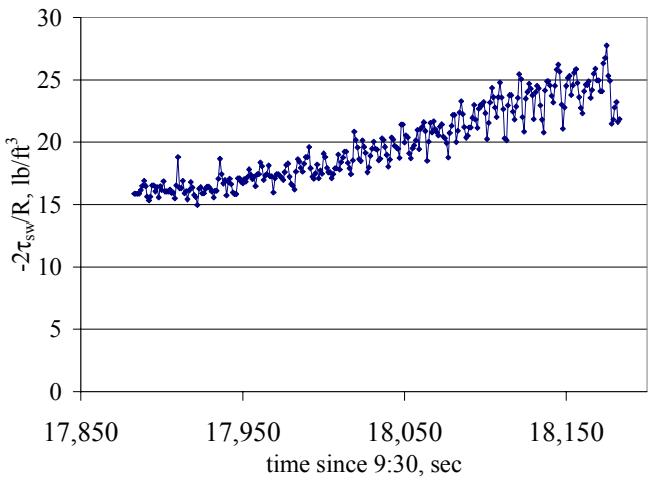

Figure 99: Example of Five Minute Steady State for Run Two, $230 \mu \mathrm{m}$ Coke

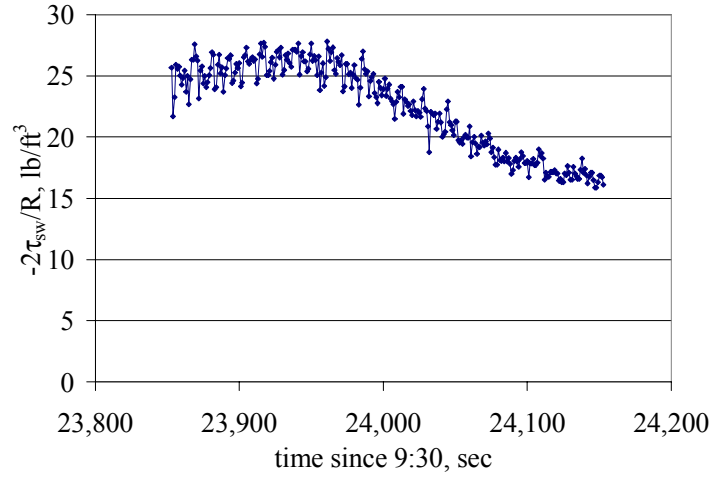

Figure 100: Example of Five Minute Steady State for Run Nine, $230 \mu \mathrm{m}$ Coke

From Table 55, the models for the hysteresis were relatively poor. Only two that had significant variables were the gas pressure drop $\left(-\Delta \mathrm{P}_{\mathrm{g}} / \mathrm{L}\right)$ and the solids circulation, 
which had $\mathrm{R}$ squared values of 0.72 and 0.71 respectively. The significant variables were aeration location and aeration at the dipleg. Further, ramp direction was close to being significant for the gas pressure drop $\left(-\Delta \mathrm{P}_{\mathrm{g}} / \mathrm{L}\right)$.

Table 55: ANOVA of Hysteresis Test for Gas Pressure Drop $\left(-\Delta \mathbf{P}_{\mathrm{g}} / \mathbf{L}\right)$, Solids Pressure Drop $\left(-\Delta P_{s} / L\right)$, Solids Circulation, and Standpipe Height, $230 \mu \mathrm{m}$ Coke

\begin{tabular}{|c|c|c|c|c|}
\hline Statistic & $\begin{array}{c}-\Delta \mathbf{P}_{\mathrm{g}} / \Delta \mathbf{L} \\
\text { Shear Vane } \\
\underline{\mathbf{l b} / \mathbf{f t}^{3}}\end{array}$ & $\begin{array}{l}-\Delta \mathbf{P}_{\mathbf{s}} / \Delta \mathbf{L} \\
\underline{\mathbf{b} / \mathbf{f t}^{3}}\end{array}$ & $\begin{array}{c}\text { Solids } \\
\text { Circulation } \\
\underline{\mathbf{l b} / \mathbf{h r}}\end{array}$ & $\begin{array}{c}\text { Standpipe } \\
\text { Height } \\
\text { ft }\end{array}$ \\
\hline Mean Square, AERATLOC & 6.234 & 9.956 & $1,808,654$ & 0.181 \\
\hline Mean Square, DPLGAERA & 10.526 & 8.677 & $2,846,390$ & 0.331 \\
\hline Mean Square, RAMPDIR & 1.468 & 0.892 & 269,987 & 0.226 \\
\hline $\begin{array}{c}\text { Mean Square, } \\
\text { AERATLOC*DPLGAERA }\end{array}$ & & 27.539 & & 0.456 \\
\hline $\begin{array}{c}\text { Mean Square, } \\
\text { AERATLOC*RAMPDIR }\end{array}$ & & 0.174 & & \\
\hline $\begin{array}{c}\text { Mean Square, } \\
\text { DPLGAERA*RAMPDIR }\end{array}$ & & 3.118 & & \\
\hline $\begin{array}{l}\text { Mean Square, AERATLOC* } \\
\text { DPLGAERA*RAMPDIR }\end{array}$ & & 33.208 & & \\
\hline $\mathrm{F}$, AERATLOC & 14.470 & 0.742 & 14.509 & 1.454 \\
\hline F, DIPLGAERA & 24.434 & 0.646 & 22.834 & 2.661 \\
\hline F, RAMPDIR & 3.408 & 0.066 & 2.166 & 1.816 \\
\hline F, AERATLOC*DPLGAERA & & 2.052 & & 3.667 \\
\hline F, AERATLOC*RAMPDIR & & 0.013 & & \\
\hline F, DPLGAERA*RAMPDIR & & 0.232 & & \\
\hline $\begin{array}{l}\text { F,AERATLOC*DPLGAERA* } \\
\text { RAMPDIR }\end{array}$ & & 2.474 & & \\
\hline Sig, AERATLOC & 0.003 & 0.414 & 0.002 & 0.253 \\
\hline Sig, DPLGAERA & 0.000 & 0.445 & 0.000 & 0.131 \\
\hline Sig, RAMPDIR & 0.090 & 0.803 & 0.167 & 0.205 \\
\hline Sig, AERATLOC*DPLGAERA & & 0.190 & & 0.082 \\
\hline Sig, AERATLOC*RAMPDIR & & 0.912 & & \\
\hline Sig, DPLGAERA*RAMPDIR & & 0.643 & & \\
\hline $\begin{array}{c}\text { Sig, AERATLOC*DPLGAERA* } \\
\text { RAMPDIR }\end{array}$ & & 0.154 & & \\
\hline Eta Squared, AERATLOC & 0.547 & 0.085 & 0.547 & 0.117 \\
\hline Eta Squared, DPLGAERA & 0.671 & 0.075 & 0.656 & 0.195 \\
\hline Eta Squared, RAMPDIR & 0.221 & 0.008 & 0.153 & 0.142 \\
\hline $\begin{array}{c}\text { Eta Squared, } \\
\text { AERATLOC*DPLGAERA }\end{array}$ & & 0.204 & & 0.250 \\
\hline Eta Squared, AERATLOC*RAMPDIR & & 0.002 & & \\
\hline Eta Squared, DPLGAERA*RAMPDIR & & 0.028 & & \\
\hline $\begin{array}{l}\text { Eta Squared, AERATLOC* } \\
\text { DPLGAERA*RAMPDIR }\end{array}$ & & 0.236 & & \\
\hline
\end{tabular}




\section{CHAPTER 6 CONCLUSIONS}

Solids phase shear stress has been experimentally measured, and solids phase pressure drop $\left(-\Delta \mathrm{P}_{\mathrm{S}} / \mathrm{L}\right)$ has been inferred under a large variety of CFB operating conditions. The purpose of the thesis was to experimentally measure solids phase shear stress to close the force balance in a section of the standpipe.

The relative contribution of the solids phase shear stress was heavily dependent on bed material. For coke breeze, solids phase shear stress and solids phase pressure drop per unit length were important forces in the momentum balance that could not be ignored. For coke breeze, the wall shear stress component was on the same order of magnitude as the gas phase pressure drop per unit length. However, for cork the wall shear stress component was always the smallest contribution to the momentum balance. It ranged from 9 to $2 \%$ of the total forces.

Equation (37) was developed from the theory commonly used for handling solids wall shear stress in standpipes that are in a packed regime (Leung, 1985; Mountziaris, 1990; Picciotti, 1995).

$\left.P_{s z}\right|_{z=z 1}=\frac{D K}{4 \mu_{w}}\left(e^{\frac{-4 \mu_{w}}{D K}\left(z_{2}-z_{1}\right)}\right)\left(\frac{\Delta P_{g}}{\Delta z}+\left.\frac{4 \mu_{w}}{D K} P_{s z}\right|_{z=z 2}-\rho_{s} \varepsilon_{s} \frac{g}{g_{c}}\right)-\frac{D K}{4 \mu_{w}}\left(\frac{\Delta P_{g}}{\Delta z}-\rho_{s} \varepsilon_{s} \frac{g}{g_{c}}\right)$ (37)

The constant $\mu_{\mathrm{w}} / \mathrm{K}$, the product of the Janssen coefficient and coefficient of friction, is repeatedly in Equation (37). The values of this constant are dependent on bed material properties. Using this product to predict wall shear stress resulted in values higher then four times the measured values. When the product of the Janssen coefficient and coefficient of friction was adjusted such that the predicted values matched the measured values, a value of 0.003 was found for both cork and coke breeze. This result was startling due to its magnitude and the fact that the same value worked well for both materials. This demonstrates that the Janssen coefficient, which is measured under nonaerated, incipient flow conditions, may not be the correct parameter to be used in the standpipe of a CFB.

Further examination of Equation (37), indicates that for a packed regime, solids phase shear stress and solids phase pressure drop $\left(-\Delta \mathrm{P}_{s} / \mathrm{L}\right)$ are based on the gas pressure drop $\left(-\Delta \mathrm{P}_{\mathrm{g}} / \mathrm{L}\right)$, axial location in the bed, and solids volume fraction of the bed material. 
For a packed regime, the axial location dependence could not be measured with confidence, and the gas pressure drop $\left(-\Delta \mathrm{P}_{\mathrm{g}} / \mathrm{L}\right)$ dependence was detected with a $90 \%$ confidence.

For a fluidized regime the solids phase shear stress and pressure drop $\left(-\Delta \mathrm{P}_{s} / \mathrm{L}\right)$ are based on the solids velocity and solids volume fraction. For a fluidized regime, the solids velocity dependence was quite small and differences were below detectable limits.

Stationary bed aeration ramps show that shear stress is a strong indicator of fluidization. These ramps also indicate that effects such as hysteresis and compaction have a large impact on solids wall shear stress.

The completed work on this project is only the start. A list of recommendations for continuing this work is below.

1. Collaborate with CFB modelers, to understand how the solids wall shear stress measurements can enhance their efforts.

2. Build a more sensitive device to measure solids-wall shear stress in the riser.

3. Evaluate the effects of wall surface roughness on wall shear stress and solids pressure. Currently, galvanized sheet metal is under study. However, there is utility in studying acrylic pipe and refractory lined pipe. Most of the CFB at NETL is constructed of acrylic, and standpipes found in energy facilities are generally refractory lined.

4. Improving calibration of probe. Check slope for upward forces. Calibrate for side-to-side stresses.

5. Use the shear vane to measure particle-particle shear, coating the sides of the vane with particles can do this. Studying particle-particle shear can give insight into what is happening away from the wall.

6. Develop a 2-D mixture momentum balance; try to predict location of inner shear layer. An interpretation of the internal angle being larger then the angle of wall friction is that the material does not slide at the wall, but breaks within the bulk. A 2-D momentum balance may be useful in predicting where this occurs. 
7. Explore the option of using the shear vane or wall probe to define fluidization. Of course standpipe regimes would have to be expressed in terms of shear stress first.

8. Continue studying different bed materials to see if the Janssen coefficient that fits the operational data varies from 0.003 . This should also bed done with different surface roughness as discussed in number 1 .

9. Continue development of solids volume fraction probe. Suspect problems are changing zeros, too small of a sampling volume, poor equation that relates $\varepsilon_{\mathrm{s}}$ to $\mathrm{K}_{\mathrm{eff}}$, and static discharge. 


\section{APPENDIX}

\section{A.1 Derivation of Mixture Momentum Balance using Shell Balance Technique}

\section{A.1.a Gas Momentum Balance:}

Consider the section of standpipe understudy in the Figure 101 below.

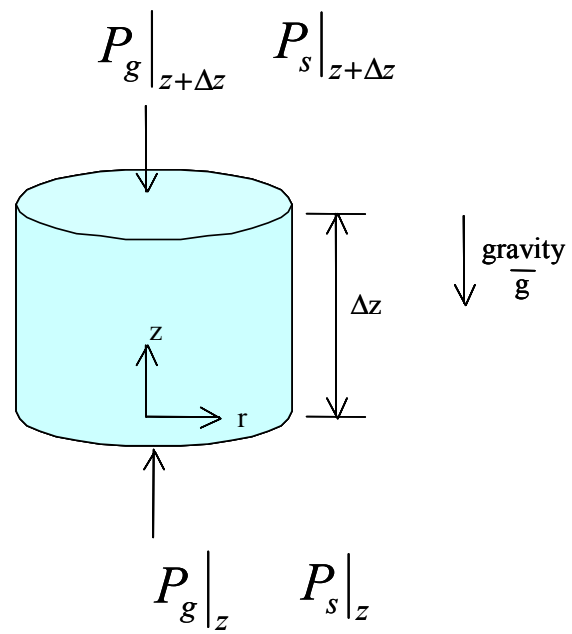

\section{Figure 101: Standpipe Force Balance Shell Balance}

The momentum balance is presented by Bird as follows:

\{rate of momentum accum. $\}=\{$ rate of momentum in $\}-\{$ rate of momentum out $\}+\{$ sum of forces acting on the system $\}$ (Bird, 1960) Each component of the momentum balance in the $\mathrm{z}$-direction will be summarized below:

- $\{$ rate of momentum accumulation $\}=0$. This is due to an assumption of steady state.

- $\quad$ rate of momentum in $\}=\left.\left(\pi R^{2} v_{g z}\right)\left(\rho_{g} \varepsilon_{g} v_{g z}\right)\right|_{z=z+\Delta z}$

- $\quad$ rate of momentum out $\}=\left.\left(\pi R^{2} v_{g z}\right)\left(\rho_{g} \varepsilon_{g} v_{g z}\right)\right|_{z=z}$

- $\{$ sum of forces action on the system $\}=\{$ gravity $\}+\{$ gas-wall shear stress $\}+\{$ gasparticle drag $\}+\{$ pressure force acting at $\mathrm{z}=\mathrm{z}\}+\{$ pressure force acting at $\mathrm{z}=\Delta \mathrm{z}\}$ Each force is described as follows:

- $\{$ gravity $\}=-\left(\pi R^{2} \Delta z\right) \rho_{g} \varepsilon_{g} \frac{g}{g_{c}}$. Note that gravity in the z-direction is negative since the $\mathrm{z}$-axis was defined to be positive up. 
- $\quad$ gas-wall shear stress $\}=(2 \pi R \Delta z) \tau_{g w}$

- $\{$ gas-particle drag $\}=-B_{A}\left(v_{g z}-v_{s z}\right)\left(\pi R^{2} \Delta z\right)$

- $\quad\{$ pressure force acting at $\mathrm{z}=\mathrm{z}\}=\left.\pi R^{2} P_{g}\right|_{z=z}$ Force is acting in the positive $\mathrm{z}$ direction.

- $\quad\{$ pressure force acting at $\mathrm{z}=\mathrm{z}+\Delta \mathrm{z}\}=-\left.\pi R^{2} P_{g}\right|_{z=z+\Delta z}$ Force is acting in the negative $\mathrm{z}-$ direction.

Placing all the components into the momentum balance gives the following assuming that the gas flows down:

$$
\begin{aligned}
& 0=\left.\left(\pi R^{2} v_{g z}\right)\left(\rho_{g} \varepsilon_{g} v_{g z}\right)\right|_{z=z+\Delta z}-\left.\left(\pi R^{2} v_{g z}\right)\left(\rho_{g} \varepsilon_{g} v_{g z}\right)\right|_{z=z}-\left(\pi R^{2} \Delta z\right) \rho_{g} \varepsilon_{g} \frac{g}{g_{c}}+(2 \pi R \Delta z) \tau_{g w}+ \\
& -B_{A}\left(v_{g z}-v_{s z}\right)\left(\pi R^{2} \Delta z\right)+\left.\left(\pi R^{2}\right) P_{g}\right|_{z=z}-\left.\left(\pi R^{2}\right) P_{g}\right|_{z=z+\Delta z}
\end{aligned}
$$

If $\varepsilon_{\mathrm{g}}$ is assumed to be constant over $\Delta \mathrm{z}$, then by the continuity equation and the assumption of steady state, the first two terms cancel out, and the following equation results:

$$
0=-\left(\pi R^{2} \Delta z\right) \rho_{g} \varepsilon_{g} \frac{g}{g_{c}}+(2 \pi R \Delta z) \tau_{g w}-B_{A}\left(v_{g z}-v_{s z}\right)\left(\pi R^{2} \Delta z\right)+\left.\left(\pi R^{2}\right) P_{g}\right|_{z=z}-\left.\left(\pi R^{2}\right) P_{g}\right|_{z=z+\Delta z}
$$

Dividing through by $\pi R^{2} \Delta z$ results in the following:

$$
0=-\rho_{g} \varepsilon_{g} \frac{g}{g_{c}}+\frac{2 \tau_{g w}}{R}-B_{A}\left(v_{g z}-v_{s z}\right)+\frac{\left.P_{g}\right|_{z=z}-\left.\left(\pi R^{2}\right) P_{g}\right|_{z=z+\Delta z}}{\Delta z}
$$

Rearranging and taking the limit as $\Delta \mathrm{z}$ goes to zero gives the following equation.

$$
\begin{aligned}
& 0=-\rho_{g} \varepsilon_{g} \frac{g}{g_{c}}+\frac{2 \tau_{g w}}{R}-B_{A}\left(v_{g z}-v_{s z}\right)-\lim _{z \rightarrow 0}\left(\frac{\left.P_{g}\right|_{z=z+\Delta z}-\left.P_{g}\right|_{z=z}}{\Delta z}\right) \\
& 0=-\rho_{g} \varepsilon_{g} \frac{g}{g_{c}}+\frac{2 \tau_{g w}}{R}-B_{A}\left(v_{g z}-v_{s z}\right)-\frac{d P_{g}}{d z}
\end{aligned}
$$

The first two terms are so small that they can be ignored. As a result, the gas momentum balance is given as follows:

$$
0=-B_{A}\left(v_{g z}-v_{s z}\right)-\frac{d P_{g}}{d z}
$$




\section{A.1.b Solids Momentum Balance:}

The derivation of the solids momentum balance follows exactly the derivation of the gas momentum balance.

The momentum balance as presented by Bird is as follows:

\{rate of momentum accum. $\}=\{$ rate of momentum in $\}-\{$ rate of momentum out $\}+\{$ sum of forces acting on the system $\}$ (Bird, 1960). Each component of the momentum balance in the z-direction will be summarized below.

- $\quad\{$ rate of momentum accumulation $\}=0$. This is due to an assumption of steady state.

- $\quad\{$ rate of momentum in $\}=\left.\left(\pi R^{2} v_{s z}\right)\left(\rho_{s} \varepsilon_{s} v_{s z}\right)\right|_{z=z+\Delta z}$

- $\quad\{$ rate of momentum out $\}=\left.\left(\pi R^{2} v_{s z}\right)\left(\rho_{s} \varepsilon_{s} v_{s z}\right)\right|_{z=z}$

- $\{$ sum of forces action on the system $\}=\{$ gravity $\}+\{$ solid-wall shear stress $\}+\{$ particle-gas drag $\}+\{$ solids pressure force acting at $\mathrm{z}=\mathrm{z}\}+\{$ solids pressure force acting at $\mathrm{z}=\Delta \mathrm{z}$ \}

Each force is described as follows:

- $\{$ gravity $\}=-\left(\pi R^{2} \Delta z\right) \rho_{s} \varepsilon_{s} \frac{g}{g_{c}}$. Note that gravity in the $\mathrm{z}$-direction is negative since the z-axis was defined to be positive up.

- $\{$ solids-wall shear stress $\}=(2 \pi R \Delta z) \tau_{s w}$

- $\{$ particle-gas drag $\}=-B_{A}\left(v_{s z}-v_{g z}\right)\left(\pi R^{2} \Delta z\right)$

- $\quad\{$ pressure force acting at $\mathrm{z}=\mathrm{z}\}=\left.\pi R^{2} P_{s}\right|_{z=z}$ Force is acting in the positive $\mathrm{z}-$ direction.

- $\quad\{$ pressure force acting at $\mathrm{z}=\mathrm{z}+\Delta \mathrm{z}\}=-\left.\pi R^{2} P_{s}\right|_{z=z+\Delta z}$ Force is acting in the negative $\mathrm{z}$ direction.

Placing all the components into the momentum balance gives the following:

$$
\begin{aligned}
& 0=\left.\left(\pi R^{2} v_{s z}\right)\left(\rho_{s} \varepsilon_{s} v_{s z}\right)\right|_{z=z+\Delta z}-\left.\left(\pi R^{2} v_{s z}\right)\left(\rho_{s} \varepsilon_{s} v_{s z}\right)\right|_{z=z}-\left(\pi R^{2} \Delta z\right) \rho_{s} \varepsilon_{s} \frac{g}{g_{c}}+(2 \pi R \Delta z) \tau_{s w}+ \\
& -B_{A}\left(v_{s z}-v_{g z}\right)\left(\pi R^{2} \Delta z\right)+\left.\left(\pi R^{2}\right) P_{s}\right|_{z=z}-\left.\left(\pi R^{2}\right) P_{s}\right|_{z=z+\Delta z}
\end{aligned}
$$


If $\varepsilon_{\mathrm{s}}$ is assumed to be constant over $\Delta \mathrm{z}$, then by the continuity equation and the assumption of steady state, the first two terms cancel out, and the following equation results:

$$
0=-\left(\pi R^{2} \Delta z\right) \rho_{s} \varepsilon_{s} \frac{g}{g_{c}}+(2 \pi R \Delta z) \tau_{s w}-B_{A}\left(v_{s z}-v_{g z}\right)\left(\pi R^{2} \Delta z\right)+\left.\left(\pi R^{2}\right) P_{s}\right|_{z=z}-\left.\left(\pi R^{2}\right) P_{s}\right|_{z=z+\Delta z}
$$

Dividing through by $\pi R^{2} \Delta z$ results in the following:

$$
0=-\rho_{s} \varepsilon_{s} \frac{g}{g_{c}}+\frac{2 \tau_{s w}}{R}-B_{A}\left(v_{s z}-v_{g z}\right)+\frac{\left.P_{s}\right|_{z=z}-\left.\left(\pi R^{2}\right) P_{s}\right|_{z=z+\Delta z}}{\Delta z}
$$

Rearranging and taking the limit as $\Delta \mathrm{z}$ goes to zero gives the following equation.

$$
\begin{aligned}
& 0=-\rho_{s} \varepsilon_{s} \frac{g}{g_{c}}+\frac{2 \tau_{s w}}{R}-B_{A}\left(v_{s z}-v_{g z}\right)-\lim _{z \rightarrow 0}\left(\frac{\left.P_{s}\right|_{z=z+\Delta z}-\left.P_{s}\right|_{z=z}}{\Delta z}\right) \\
& 0=-\rho_{s} \varepsilon_{s} \frac{g}{g_{c}}+\frac{2 \tau_{s w}}{R}-B_{A}\left(v_{s z}-v_{g z}\right)-\frac{d P_{s}}{d z}
\end{aligned}
$$

Unlike in the gas momentum balance the first term cannot be ignored. The second term is solids-wall shear stress, and is the term understudy.

\section{A.1.c Mixture Momentum Balance:}

The mixture momentum balance is found simply by adding the gas momentum balance and solids momentum balance. (Gidaspow, 1994)

$$
0+0=-B_{A}\left(v_{g z}-v_{s z}\right)-\frac{d P_{g}}{d z}-\rho_{s} \varepsilon_{s} \frac{g}{g_{c}}+\frac{2 \tau_{s w}}{R}-B_{A}\left(v_{s z}-v_{g z}\right)-\frac{d P_{s}}{d z}
$$

Fortunately, the gas-particle drag terms cancel out and the resulting equation is as follows: $0=-\frac{d P_{g}}{d z}-\rho_{s} \varepsilon_{s} \frac{g}{g_{c}}+\frac{2 \tau_{s w}}{R}-\frac{d P_{s}}{d z}$ 


\section{A.2 Derivation of Equations For Estimating Shear Stress and Solids Pressure}

\section{A.2a Assuming Constant $\mathrm{DP}_{g} / \mathrm{L}$ Along the Standpipe}

Starting with the microscopic form of the mixture momentum balance below:

$$
\frac{\partial P_{s z}}{\partial z}+\frac{\partial P_{g}}{\partial z}+\frac{2 \tau_{s w}}{R}-\rho_{s} \varepsilon_{s} \frac{g}{g_{c}}+v_{s} \varepsilon_{s} \rho_{s} \frac{d v_{s}}{d z}=0
$$

Signs are slightly different due to positive z-axis is down in the direction of gravity. See Figure 106.

It is assumed that the solids velocity is not a function of height in the standpipe. Therefore, the last term is zero.

$$
\frac{\partial P_{s z}}{\partial z}+\frac{\partial P_{g}}{\partial z}+\frac{2 \tau_{s w}}{R}-\rho_{s} \varepsilon_{s} \frac{g}{g_{c}}=0
$$

From bulk solids mechanics, shear stress is related to the axial solids pressure by the following equation.

$$
\tau_{s w}=\frac{\mu_{w}}{K} P_{s z}
$$

Substituting this equation into the into the mixture momentum balance gives

$$
\frac{\partial P_{s z}}{\partial z}+\frac{\partial P_{g}}{\partial z}+\frac{2 \mu_{w} P_{s z}}{R K}-\rho_{s} \varepsilon_{s} \frac{g}{g_{c}}=0
$$

Assuming that pressure drop per unit length is constant, the following relationship can be substituted for $\mathrm{dP}_{\mathrm{g}} / \mathrm{dz}$. See Figure 102 below.

$$
\frac{d P_{g}}{d z}=\frac{P 1-P 2}{0-H}=-\frac{\Delta P_{g}}{H}
$$




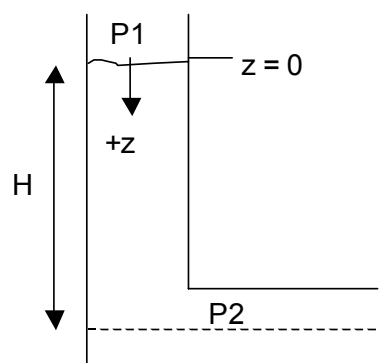

\section{Figure 102: Derivation of Solids Pressure Equation Drawing 1}

Substituting this realationship into the mixture momentum balance gives

$\frac{d P_{s z}}{d z}-\frac{\Delta P_{g}}{H}+\frac{2 \mu_{w} P_{s z}}{R K}-\rho_{s} \varepsilon_{s} \frac{g}{g_{c}}=0$

The above equation is integrated from $\mathrm{z}=0$ to $\mathrm{z}=\mathrm{z}$. Keep in mind that solids pressure is zero at $\mathrm{z}=0$, the top of the bed. This integration is performed using separation of variables below.

Rearranging.

$\frac{\partial P_{s z}}{\partial z}=\frac{\Delta P_{g}}{H}-\frac{2 \mu_{w} P_{s z}}{R K}+\rho_{s} \varepsilon_{s} \frac{g}{g_{c}}$

Dividing by $\mathrm{dz}$

$d P_{s z}=\left(\frac{\Delta P_{g}}{H}-\frac{2 \mu_{w}}{R K} P_{s z}+\rho_{s} \varepsilon_{s} \frac{g}{g_{c}}\right) d z$

Rearranging

$\frac{1}{\left(\frac{\Delta P_{g}}{H}-\frac{2 \mu_{w}}{R K} P_{s z}+\rho_{s} \varepsilon_{s} \frac{g}{g_{c}}\right)} d P_{s z}=d z$

$\int \frac{1}{\left(\frac{\Delta P_{g}}{H}-\frac{2 \mu_{w}}{R K} P_{s z}+\rho_{s} \varepsilon_{s} \frac{g}{g_{c}}\right)} d P_{s z}=\int d z$

let $u=\frac{\Delta P_{g}}{H}-\frac{2 \mu_{w}}{R K} P_{s z}+\rho_{s} \varepsilon_{s} \frac{g}{g_{c}}$ 


$$
\begin{aligned}
& \frac{d u}{d P_{s, z}}=-\frac{2 \mu_{w}}{R K} \\
& d P_{s z}=-\frac{R K}{2 \mu_{w}} d u \\
& -\frac{R K}{2 \mu_{w}} \int_{u_{1}}^{u_{2}} \frac{1}{u} d u=\int_{0}^{z} d z \\
& -\frac{R K}{2 \mu_{w}} \ln \frac{u_{2}}{u_{1}}=z \\
& \ln \frac{u_{2}}{u_{1}}=-\frac{2 \mu_{w}}{R K} z \\
& \frac{u_{2}}{u_{2}}=e^{-\frac{2 \mu_{w}}{R K}} \\
& \frac{u_{2}}{u_{1}}=\frac{\frac{\Delta P_{g}}{H}-\left.\frac{2 \mu_{w}}{R K} P_{s z}\right|_{z 2}+\rho_{s} \varepsilon_{s} \frac{g}{g_{c}}}{\frac{\Delta P_{g}}{H}+\rho_{s} \varepsilon_{s} \frac{g}{g_{c}}}=e^{-\frac{2 \mu_{w}}{R K} z} \\
& \frac{\Delta P_{g}}{H}-\left.\frac{2 \mu_{w}}{R K} P_{s z}\right|_{z 2}+\rho_{s} \varepsilon_{s} \frac{g}{g_{c}}=\left(e^{\frac{-2 \mu_{w}}{R K}}\right)\left(\frac{\Delta P_{g}}{H}+\rho_{s} \varepsilon_{s} \frac{g}{g_{c}}\right) \\
& -\left.\frac{2 \mu_{w}}{R K} P_{s z}\right|_{z 2}=\left(e^{\frac{-2 \mu_{w}}{R K}} z\right)\left(\frac{\Delta P_{g}}{H}+\rho_{s} \varepsilon_{s} \frac{g}{g_{c}}\right)-\left(\frac{\Delta P_{g}}{H}+\rho_{s} \varepsilon_{s} \frac{g}{g_{c}}\right) \\
& \left.P_{s z}\right|_{z 2}=-\frac{R K}{2 \mu_{w}}\left(e^{\frac{-2 \mu_{w}}{R K}}\right)\left(\frac{\Delta P_{g}}{H}+\rho_{s} \varepsilon_{s} \frac{g}{g_{c}}\right)+\frac{R K}{2 \mu_{w}}\left(\frac{\Delta P_{g}}{H}+\rho_{s} \varepsilon_{s} \frac{g}{g_{c}}\right) \\
& P_{s, z}=\frac{R K}{2 \mu_{w}}\left[\rho_{s} \varepsilon_{s} \frac{g}{g_{c}}+\frac{\Delta P_{g}}{H}\right]\left[1-e^{\frac{-2 \mu_{w} z}{R K}}\right]
\end{aligned}
$$

\section{A.2b Integrating the Mixture Momentum Balance from $z=z_{1}$ to $z=z_{2}$}

Starting with the microscopic form of the mixture momentum balance below:

$$
\frac{-\partial P_{s z}}{\partial z}-\frac{\partial P_{g}}{\partial z}+\frac{4 \tau_{s w}}{D}-\rho_{s} \varepsilon_{s} \frac{g}{g_{c}}+v_{s} \varepsilon_{s} \rho_{s} \frac{d v_{s}}{d z}=0
$$


It is assumed that the solids velocity is not a function of height in the standpipe. Therefore, the last term is zero.

$$
\frac{-\partial P_{s z}}{\partial z}-\frac{\partial P_{g}}{\partial z}+\frac{4 \tau_{s w}}{D}-\rho_{s} \varepsilon_{s} \frac{g}{g_{c}}=0
$$

From bulk solids mechanics, shear stress is related to the axial solids pressure by the following equation.

$$
\tau_{s w}=\frac{\mu_{w}}{K} P_{s z}
$$

Substituting this equation into the into the mixture momentum balance gives

$$
\frac{-\partial P_{s z}}{\partial z}-\frac{\partial P_{g}}{\partial z}+\frac{4 \mu_{w} P_{s z}}{D K}-\rho_{s} \varepsilon_{s} \frac{g}{g_{c}}=0
$$

Assuming that pressure drop per unit length is constant, the following relationship can be substituted for $\mathrm{dP}_{\mathrm{g}} / \mathrm{dz}$. See Figure 103 below

$$
-\frac{d P_{g}}{d z}=-\frac{\left.P_{g}\right|_{z 2}-\left.P_{g}\right|_{z 1}}{z 2-z 1}=-\frac{\Delta P_{g}}{\Delta z}
$$

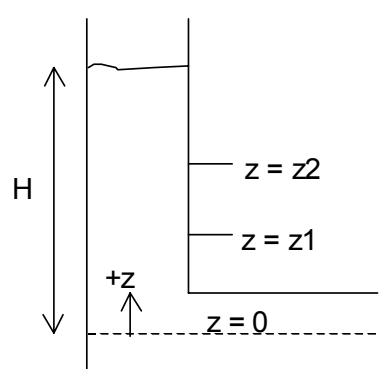

Figure 103: Derivation of Solids Pressure Equation Drawing 2

Substituting this realationship into the mixture momentum balance gives

$\frac{-d P_{s z}}{d z}-\frac{\Delta P_{g}}{\Delta z}+\frac{4 \mu_{w} P_{s z}}{D K}-\rho_{s} \varepsilon_{s} \frac{g}{g_{c}}=0$

The above equation is integrated from $\mathrm{z}=\mathrm{z} 1$ to $\mathrm{z}=\mathrm{z} 2$. Keep in mind that solids pressure is zero at $\mathrm{z}=\mathrm{H}$, the top of the bed. This integration is performed using separation of variables below.

Rearranging. 


$$
\frac{\partial P_{s z}}{\partial z}=-\frac{\Delta P_{g}}{\Delta z}+\frac{4 \mu_{w} P_{s z}}{D K}-\rho_{s} \varepsilon_{s} \frac{g}{g_{c}}
$$

Dividing by $\mathrm{dz}$

$$
d P_{s z}=\left(-\frac{\Delta P_{g}}{\Delta z}+\frac{4 \mu_{w}}{D K} P_{s z}-\rho_{s} \varepsilon_{s} \frac{g}{g_{c}}\right) d z
$$

Rearranging

$$
\begin{aligned}
& \frac{1}{\left(-\frac{\Delta P_{g}}{\Delta z}+\frac{4 \mu_{w}}{D K} P_{s z}-\rho_{s} \varepsilon_{s} \frac{g}{g_{c}}\right)} d P_{s z}=d z \\
& \int \frac{1}{\left(-\frac{\Delta P_{g}}{\Delta z}+\frac{4 \mu_{w}}{D K} P_{s z}-\rho_{s} \varepsilon_{s} \frac{g}{g_{c}}\right)} d P_{s z}=\int d z
\end{aligned}
$$

let $u=-\frac{\Delta P_{g}}{\Delta z}+\frac{4 \mu_{w}}{D K} P_{s z}-\rho_{s} \varepsilon_{s} \frac{g}{g_{c}}$

$$
\begin{aligned}
& \frac{d u}{d P_{s, z}}=\frac{4 \mu_{w}}{D K} \\
& d P_{s z}=\frac{D K}{4 \mu_{w}} d u
\end{aligned}
$$

$$
\frac{D K}{4 \mu_{w}} \int_{u_{1}}^{u_{2}} \frac{1}{u} d u=\int_{z_{1}}^{z_{2}} d z
$$$$
\frac{D K}{4 \mu_{w}} \ln \frac{u_{2}}{u_{1}}=\left(z_{2}-z_{1}\right)
$$$$
\ln \frac{u_{2}}{u_{1}}=\frac{4 \mu_{w}}{D K}\left(z_{2}-z_{1}\right)
$$$$
\frac{u_{2}}{u_{1}}=e^{\frac{4 \mu_{w}}{D K}\left(z_{2}-z_{1}\right)}
$$

$$
\frac{u_{2}}{u_{1}}=\frac{-\frac{\Delta P_{g}}{\Delta z}+\left.\frac{4 \mu_{w}}{D K} P_{s z}\right|_{z=z 2}-\rho_{s} \varepsilon_{s} \frac{g}{g_{c}}}{-\frac{\Delta P_{g}}{\Delta z}+\left.\frac{4 \mu_{w}}{D K} P_{s z}\right|_{z=z 1}-\rho_{s} \varepsilon_{s} \frac{g}{g_{c}}}=e^{\frac{4 \mu_{w}}{D K}\left(z_{2}-z_{1}\right)}
$$




$$
\begin{aligned}
& -\frac{\Delta P_{g}}{\Delta z}+\left.\frac{4 \mu_{w}}{D K} P_{s z}\right|_{z=z 1}-\rho_{s} \varepsilon_{s} \frac{g}{g_{c}}=\left(e^{\left.\frac{-4 \mu_{w}}{D K} z_{2}-z_{1}\right)}\right)\left(-\frac{\Delta P_{g}}{\Delta z}+\left.\frac{4 \mu_{w}}{D K} P_{s z}\right|_{z=z 2}-\rho_{s} \varepsilon_{s} \frac{g}{g_{c}}\right) \\
& \left.\frac{4 \mu_{w}}{D K} P_{s z}\right|_{z=z 1}=\left(e^{\frac{-4 \mu_{w}}{D K}\left(z_{2}-z_{1}\right)}\right)\left(-\frac{\Delta P_{g}}{\Delta z}+\left.\frac{4 \mu_{w}}{D K} P_{s z}\right|_{z=z 2}-\rho_{s} \varepsilon_{s} \frac{g}{g_{c}}\right)-\left(-\frac{\Delta P_{g}}{\Delta z}-\rho_{s} \varepsilon_{s} \frac{g}{g_{c}}\right) \\
& \left.P_{s z}\right|_{z=z 1}=\frac{D K}{4 \mu_{w}}\left(e^{\frac{-4 \mu_{w}}{D K}\left(z_{2}-z_{1}\right)}\right)\left(-\frac{\Delta P_{g}}{\Delta z}+\left.\frac{4 \mu_{w}}{D K} P_{s z}\right|_{z=z 2}-\rho_{s} \varepsilon_{s} \frac{g}{g_{c}}\right)-\frac{D K}{4 \mu_{w}}\left(-\frac{\Delta P_{g}}{\Delta z}-\rho_{s} \varepsilon_{s} \frac{g}{g_{c}}\right)
\end{aligned}
$$




\section{A.3 Bulk Solids Mechanics}

This section discusses bulk solids mechanics and the derivation of equations (22) thru (27). McCabe (1993) listed distinctive properties of solids:

1. Solids exert pressure, which is not the same in all directions. The pressure is a minimum at right angles to the direction it is applied.

2. Shear stress applied to the surface of a static mass is transmitted throughout the mass until failure occurs.

3. The density of the mass depends on the packing (solids volume fraction)

4. Before a mass of tightly packed particles can flow, it must expand to permit interlocking particles to move past one another.

McCabe (1993) also discussed the two classes of particulate solids, cohesive and noncohesive. Noncohesive materials readily flow, and cohesive solids are more resistant to flow. Some examples of noncohesive materials are dry sand and grain. An example of cohesive materials is clay.

Number (4) above suggests that the pressure normal to the applied is the minimum pressure. McCabe suggests that the ratio of the applied to normal pressure is a constant $\mathrm{K}^{\prime}$, and that this constant is a function of material properties such as shape and stickiness. Consider the right-angled triangular differential section of thickness, $b$, and hypotenuse, dL in Figure 104 below.

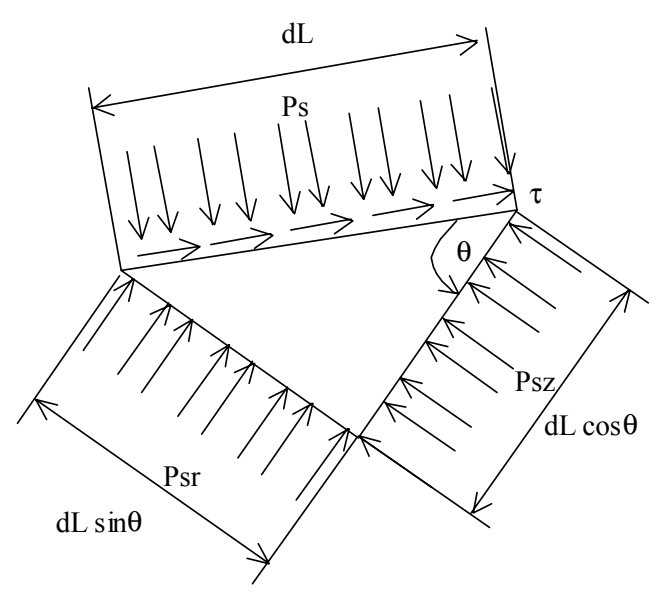

Figure 104: Differential Triangular Element 
The applied pressure is $\mathrm{P}_{\mathrm{sz}}$ and the normal pressure is $\mathrm{P}_{\mathrm{sr}}$. $\mathrm{P}_{\mathrm{s}}$ is the pressure at any intermediate angle, and $\tau$ is the shear stress necessary to keep the element from rotating. The element and the forces resulting from the pressures and stresses are shown in Figure 105.

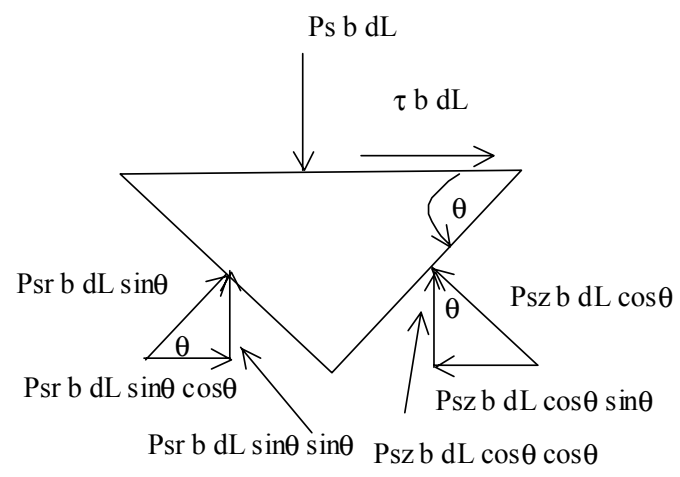

\section{Figure 105: Differential Element and Resulting Forces}

Equating the components at right angles to the hypotenuse gives the following:

$P_{s} b d L=P_{s r} b d L \sin ^{2} \theta+P_{s z} b d L \cos ^{2} \theta$

Dividing by bdL gives the following

$P_{s}=P_{s r} \sin ^{2} \theta+P_{s z} \cos ^{2} \theta$

Note that $\sin ^{2} \theta=1-\cos ^{2} \theta$

$P_{s}=P_{s r}\left(1-\cos ^{2} \theta\right)+P_{s z} \cos ^{2} \theta$

$P_{s}=\left(P_{s z}-P_{s r}\right) \cos ^{2} \theta+P_{s r}$

Equating forces parallel to the hypotenuse gives the following:

$\tau b d L=P_{s z} b d L \cos \theta \sin \theta-P_{s r} b d L \sin \theta \cos \theta$

dividing by bdL

$\tau=\left(P_{s z}-P_{s r}\right) \sin \theta \cos \theta$ 
If all corresponding values of $\mathrm{P}_{\mathrm{s}}$ and $\tau$ are plotted for all $\theta$, then a Mohr circle results.

This circle has a radius of $\left(P_{s z}-P_{s r}\right) / 2$, and its horizontal circle is at $P_{s}=\left(P_{s z}+P_{s r}\right) / 2$. See Figure 106 below.

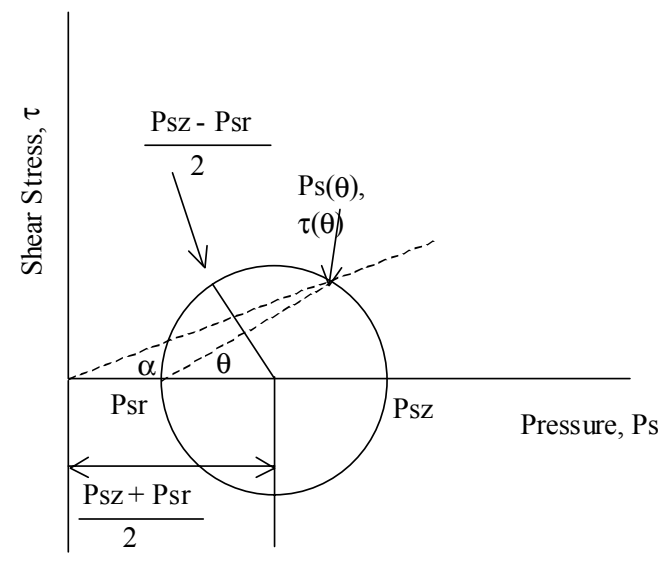

Figure 106: Mohr Stress Circle for Particulate Solids 1

Looking at Figure 106, it is evident that when $\theta$ is zero degrees, $\mathrm{P}_{\mathrm{s}}$ is $\mathrm{P}_{\mathrm{sz}}$ and shear stress is zero. Also, when $\theta$ is 90 degrees, $P_{s}$ is $P_{s r}$ and shear stress is zero. For an intermediate value of $\theta$, there is a corresponding $P_{s}$ and shear stress. The ratio of $\tau$ to $P_{s}$ at any value of $\theta$ is the tangent of the angle, $\alpha$. This angle is formed by a line drawn from the origin to the corresponding point on the Mohr circle with the x-axis. As $\theta$ is increased, this ratio increases to a maximum at which point the line through the origin is tangent to the Mohr circle after which point the ratio decreases. Figure 107 shows this maximum point. 


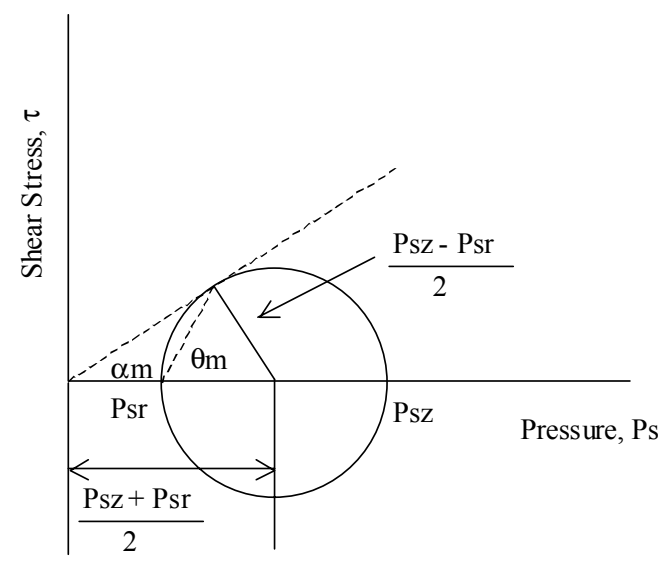

Figure 107: Mohr Stress Circle for Particulate Solids Maximum Ratio of $\tau$ to $P_{s}$

From Figure 107, $\sin \alpha_{m}=\frac{\left(P_{s z}-P_{s r}\right) / 2}{\left(P_{s z}+P_{s r}\right) / 2}=\frac{P_{s z}-P_{s r}}{P_{s z}+P_{s r}}$

Let $\frac{P_{s r}}{P_{s z}}=K$. Then, $P_{s r}=K P_{s z}$

$\sin \alpha_{m}=\frac{P_{s z}-K P_{s z}}{P_{s z}+K P_{s z}}=\frac{P_{s z}((1-K)}{P_{s z}((1+K)}=\frac{1-K}{1+K}$

$\sin \alpha_{m}=\frac{1-K}{1+K}$

$1-K=(1+K) \sin \alpha_{m}=\sin \alpha_{m}+K \sin \alpha_{m}$

$1-\sin \alpha_{m}=K+K \sin \alpha_{m}=K\left(1+\sin \alpha_{m}\right)$

$K=\frac{1-\sin \alpha_{m}}{1+\sin \alpha_{m}}$

The tangent of the internal angle of friction is the coefficient of friction between two layers of particles. 


\section{NOMENCLATURE}

A Surface area of the control volume

$\mathrm{B}_{\mathrm{A}} \quad$ Drag

CV Contol Volume

CS Control Surface

D Diameter of the standpipe

d Displacement distance for the bending tube in the wall probe

$\mathrm{d}_{\mathrm{p}} \quad$ Particle diameter

E Modulus of elasticity

F Total Force applied to the control volume

F Total force applied to the free end of the bending tube in the wall probe

$\mathrm{F}_{\mathrm{m}} \quad$ Aeration rate at $0.3^{\prime}$ in the standpipe

$\mathrm{F}_{\mathrm{z}} \quad$ Forces in the $\mathrm{z}$-direction

e Coefficient of restitution for particle-particle collisions

g Acceleration due to gravity

$\mathrm{g}_{\mathrm{c}} \quad$ Universal gravitational constant

go Radial distribution function

$\mathrm{H} \quad$ Height of the bed in the standpipe

I Moment of inertia

1/K Janssen coefficient

$\mathrm{K}_{\mathrm{p}} \quad$ Particle dielectric constant

$\mathrm{K}_{\mathrm{h}} \quad$ Dielectric constant of host material (air)

$\mathrm{K}_{\text {eff }}$ Effective Dielectric constant of the suspension

L Length of the control volume, or the length of the bending tube in the wall probe

$\dot{m}_{g} \quad$ Mass flowrate of gas phase

$\dot{m}_{s} \quad$ Mass flowrate of solids phase

$\mathrm{P}_{1} \quad$ Gas phase pressure at the top of the standpipe

$\mathrm{P}_{2} \quad$ Gas phase pressure at the bottom of the standpipe

$\mathrm{P}_{\mathrm{g}} \quad$ Gas phase pressure

$\mathrm{P}_{\mathrm{s}} \quad$ Solids phase pressure 
$\mathrm{P}_{\mathrm{sz}} \quad$ Solids phase pressure in the axial direction

$\mathrm{P}_{\mathrm{sr}} \quad$ Solids phase pressure in the radial direction

$\mathrm{T}_{\mathrm{s}} \quad$ Granular Temperature

$\mathrm{U}_{\mathrm{g}} \quad$ Gas phase velocity

$\mathrm{U}_{\mathrm{s}} \quad$ Solids phase velocity

$\mathrm{U}_{\mathrm{sl}} \quad$ Slip velocity

$\mathrm{U}_{\mathrm{mf}} \quad$ Superficial minimum fluidization velocity

$\mathrm{V} \quad$ Volume of control volume

$\mathrm{V} \quad$ Voltage response to to suspension

$\mathrm{V}_{\text {bed }} \quad$ Volume of the bed

$\mathrm{V}_{0} \quad$ Voltage response due to air

$\mathrm{v}_{\mathrm{gz}} \quad$ Gas phase velocity in the axial direction

$\vec{v}_{g} \quad$ Gas phase velocity vector

$\vec{v}_{s} \quad$ Solids phase velocity vector

$\mathrm{v}_{\mathrm{sz}} \quad$ Solids phase velocity in the axial direction

$\mathrm{R} \quad$ Radius of standpipe

$\mathrm{r}_{\mathrm{o}} \quad$ Outside radius of the bending tube in the wall probe

$\mathrm{r}_{\mathrm{i}} \quad$ Inside radius of the bending tube in the wall probe

$\mathrm{x}$ distance from the fixed end of the tube to the estimation of "d" for the bending tube in the wall probe

$\mathrm{z} \quad$ axial direction

$\mathrm{Z}_{1} \quad$ Top of standpipe section measured down from the top of the bed

$z_{2} \quad$ Bottom of standpipe section measured down from the top of the bed

$\alpha \quad$ Resistance of the material to flow

$\delta \quad$ Effective internal angle of friction

$\delta_{\mathrm{w}} \quad$ External angle of friction

$\Delta \mathrm{P} \quad$ Total pressure drop across the standpipe

$\varepsilon_{\mathrm{c}} \quad$ Vibrated void fraction

$\varepsilon_{\mathrm{g}} \quad$ Void fraction

$\varepsilon \quad$ Void fraction

$\varepsilon_{\mathrm{mf}} \quad$ Void fraction at minimum fluidization 
$\varepsilon_{\mathrm{s}} \quad$ Volume fraction of the solids phase

$\rho_{b} \quad$ Bulk density

$\rho_{g} \quad$ Density of gas phase

$\rho_{\mathrm{s}} \quad$ Density of solids phase

$\tau_{\mathrm{sw}} \quad$ Solids wall shear stress

$\tau_{\mathrm{gw}} \quad$ Gas wall shear stress

$\mu_{\mathrm{w}} \quad$ Coefficient of friction between solid and wall surface 


\section{REFERENCES}

- Bird, R.B., W.E. Stewart, and E.N. Lightfoot. Transport Phenomena. New York: John Wiley \& Sons (1960).

- Brown, R.L., J.C. Richards. Principles of Powder Mechanics. Oxford: Pergamon Press (1970).

- Doebelin, Ernest O. Measurement Systems Application and Design $3^{\text {rd }}$ Edition. New York: McGraw-Hill Book Company (1983).

- Geankoplis, Christie J. Transport Process and Unit Operations $3^{\text {rd }}$ Edition.. Englewood Cliffs, NJ: PTR Prentice Hall (1993)

- Gidaspow, Dimitri. Multiphase Flow and Fluidization Continuum and Kinetic Theory Descriptions. San Diego, California: Academic Press, Inc (1994).

- GRANORTE - Revestimentos de Cortiça, Lda. "Properties of Cork," http://www.granorte.pt/properties.htm (2001).

- Higdon, Archie, Edward Ohlsen, William Stiles, John Weese, William Riley. Mechanics of Materials Fourth Edition. New York: John Wiley \& Sons (1985).

- Knowlton, T.M. "Standpipes," in D. Geldart. Gas Fluidization Technology. Chichester, New York: John Wiley and Sons Ltd. (1986).

- Jones, P.J. and L.S. Leung. "Downflow of Solids through Pipes and Valves," in J.E.Davidson. Fluidization second Edition. London: Academic Press (1985).

- Louge, Michel. "Measuring particle concentration with capacitance probes," provided by Capacitech Inc. (1992).

- Louge, Michel, Mark Tuccio, Euardo Lander, and Patric Connors. "Capacitance measurements of the volume fraction and velocity of dielectric near a grounded wall,” Rev. Sci. Instrum., Vol. 67, No.5, May, pp. 1869-1877 (1996).

- Leung, L.S. and Robert J. Wiles. "A Quantitative Design Procedure for Vertical Pneumatic Conveying Systems," Ind. Eng. Chem., Process Des. Dev., Vol. 15, No. 4, pp. 552-557 (1976).

- Ludlow, J. Christopher, Lawrence J. Shadle, and Madhava Syamlal. (2002). "Development of Spiral Device for Measuring Solids Flow," to be presented at the $7^{\text {th }}$ International Conference on Circulating Fluidized beds, (2002). 
- Matsen, J.M. "Some Characteristics of Large Solids Circulation Systems," in D.L. Keairns. Fluidization Technology Vol II. Washington, D.C.: Hemisphere Publishing Corporation, pp. 135-149 (1976).

- McCabe, Warren L., Julian C. Smith, and Peter Harriott. Unit Operations of Chemical Engineering. New York: McGraw-Hill, Inc. (1993).

- Miller, A. and D. Gidaspow. "Dense, Vertical Gas-Solids Flow in a Pipe," AIChE Journal. 1992, 38, 1801 (199).

- Mountziaris, Triantafillos and Roy Jackson. "The Effects of Aeration on the Gravity Flow of Particles and Gas in Vertical Standpipes," Chemical Engineering Science, Vol. 46, No.2 pp. 381-407 (1990).

- Picciotti, Marcello. "Specify standpipes and feeder valves for packed beds," Chem. Eng. Prog. 91(1),54-63 (1995).

- Polashenski, William Jr., and John C. Chen. "Measurement of Particle Phase Stresses in Fast Fluidized Beds," Ind. Eng. Chem. Res., 38, 705-713 (1999).

- Shadle, Lawrence J., J. Christopher Ludlow, Larry O. Lawson, and Esmail R. Monazam. "Transport Reactor studies in FETC's Cold Flow Circulating Fluid Bed," Transport Reactor Cooperative Research and Development Agreement Report. CRADA NO. 98-F015, December 1999

- SPSS Inc., Trial Run 1.0 User's Guide. (1997).

- Schmidt, Stephen, and Robert Launsby. Understanding Industrial Designed Experiments. Colorado Springs, Colorado: Air Academy Press (1998).

- Schulze, Dietmar. "Fundamentals of Bulk Solids Mechanics," http://www.dietmar-schulze.de/grdle1.html (2000).

- Stermerding, S. "The pneumatic transport of cracking catalyst in vertical risers," Chemical Engineering Science, 1962, 17, 599-608 (1962).

- Von Hippel, Arthur. Dielectric Materials and Applications. Cambridge, Massachusetts: The MIT Press (1954)

- Zenz, Frederick A. and Donald F. Othmer. Fluidization and Fluid-Particle Systems. New York: Reinhold publishing Corporation (1960). 